Florida International University FIU Digital Commons

FIU Electronic Theses and Dissertations

University Graduate School

$11-9-2012$

\title{
Top Down Control in a Relatively Pristine Seagrass Ecosystem
}

Derek A. Burkholder

Florida International University, derek.burkholder@fiu.edu

DOI: $10.25148 /$ etd.FI12120704

Follow this and additional works at: https://digitalcommons.fiu.edu/etd

\section{Recommended Citation}

Burkholder, Derek A., "Top Down Control in a Relatively Pristine Seagrass Ecosystem" (2012). FIU Electronic Theses and Dissertations. 799.

https://digitalcommons.fiu.edu/etd/799

This work is brought to you for free and open access by the University Graduate School at FIU Digital Commons. It has been accepted for inclusion in FIU Electronic Theses and Dissertations by an authorized administrator of FIU Digital Commons. For more information, please contact dcc@fiu.edu. 


\title{
FLORIDA INTERNATIONAL UNIVERSITY
}

Miami, Florida

\section{TOP DOWN CONTROL IN A RELATIVELY PRISTINE SEAGRASS ECOSYSTEM}

\author{
A dissertation submitted in partial fulfillment of \\ the requirements for the degree of \\ DOCTOR OF PHILOSOPHY \\ in \\ BIOLOGY \\ by \\ Derek Anthony Burkholder
}


To: Dean Kenneth Furton

College of Arts and Sciences

This dissertation, written by Derek Anthony Burkholder, and entitled Top Down Control in a Seagrass Ecosystem, having been approved in respect to style and intellectual content, is referred to you for judgment.

We have read this dissertation and recommend that it be approved.

Maureen A. Donnelly

James W. Fourqurean

Joel T. Heinen

Joel C. Trexler

Michael R. Heithaus, Major Professor

Date of Defense: November 9, 2012

The dissertation of Derek Anthony Burkholder is approved.

$\begin{array}{r}\begin{array}{r}\text { Dean Kenneth Furton } \\ \text { College of Arts and Sciences }\end{array} \\ \hline \begin{array}{r}\text { Dean Lakshmi N. Reddi } \\ \text { University Graduate School }\end{array}\end{array}$

Florida International University, 2012 


\section{ACKNOWLEDGMENTS}

The logistics and challenges of working in a remote field site halfway around the world can be staggering. Anyone who has spent time working on a long-term collaborative research project can understand what it can take to keep the countless wheels turning. I would first like to thank the numerous volunteers for all of their hard work and dedication that has made this project possible. I would like to thank the staff of Western Australia's Department of Environment and Conservation in Shark Bay, with a special thanks to Dave Holley, Wayne Moroney, Brett Fitzgerald, and Tim Grubba for logistical and field support. Blue Lagoon Pearls, Monkey Mia Wildsights, and the Shark Bay Fish Factory provided critical logistical, field, and financial support. Without the generous support of the Monkey Mia Dolphin Resort for lodging and logistical support this project would not have been possible.

I would like to thank my committee members Mo Donnelly, Joel Trexler, and Joel Heinen for helping to shape the project, and providing support and input throughout my degree. I would especially like to thank Jim Fourqurean as a committee member, and for introducing me to a myriad of field and analytical techniques for the seagrass related work presented here.

A special thanks to my friends in Florida, Shark Bay and around the globe for making my graduate career such a fun and rewarding experience, and for making those long windy days in Shark Bay tolerable!!

I would like to thank my lab mates in the Heithaus lab for many great discussions and help. I would especially like to thank Jordan Thomson, Jeremy Vaudo, Kirk Gastrich, Meagan Dunphy-Daly, and Cindy Bessey! 
Lastly, I would like to thank my advisor, Mike Heithaus. He has been instrumental in the success of my graduate career, providing immeasurable support financially, logistically, academically, technically, and morally. More than that Mike has proved to be an incredible friend and I am ever indebted to him.

Funding was provided by National Science Foundation grants OCE0526065 and OCE0745606 to M. Heithaus and Florida International University's College of Arts and Sciences. Support also came from a PADI Aware grant $\# 253$ to D. Burkholder as well as a Dissertation Evidence Acquisition and Dissertation Year Fellowships from the FIU Graduate School. I would like to thank Jopalo Boats, Bombadier Recreation Products, Humminbird, The Airline, and Submersible Systems for significant donations in the form of discounts on boats and equipment. Permission to use Chapters II, and IV kindly provided by Inter-Research, and Chapter III kindly provided by CSIRO Publishing. 


\section{ABSTRACT OF THE DISSERTATION \\ TOP DOWN CONTROL IN A SEAGRASS ECOSYSTEM}

by

Derek Anthony Burkholder

Florida International University, 2012

Miami, Florida

Professor Michael R. Heithaus, Major Professor

The loss of large-bodied herbivores and/or top predators has been associated with large-scale changes in terrestrial, freshwater, and marine ecosystems around the world. Understanding the consequences of these declines has been hampered by a lack of studies in relatively pristine systems. To fill this gap, I investigated the dynamics of the relatively pristine seagrass ecosystem of Shark Bay, Australia. I began by examining the seagrass species distributions, stoichiometry, and patterns of nutrient limitation across the whole of Shark Bay. Large areas were N-limited, P-limited, or limited by factors other than nutrients. Phosphorus-limitation was centered in areas of restricted water exchange with the ocean. Nutrient content of seagrasses varied seasonally, but the strength of seasonal responses were species-specific. Using a cafeteria-style experiment, I found that fast-growing seagrass species, which had higher nutrient content experienced higher rates of herbivory than slow-growing species that are dominant in the bay but have low nutrient content. Although removal rates correlated well with nutrient content at a broad scale, within fast-growing species removal rates were not closely tied to $\mathrm{N}$ or $\mathrm{P}$ content. Using a combination of stable isotope analysis and animal borne video, I found that green turtles (Chelonia mydas) - one of the most abundant large-bodied herbivores in Shark 
Bay - appear to assimilate little energy from seagrasses at the population level. There was, however, evidence of individual specialization in turtle diets with some individuals foraging largely on seagrasses and others feeding primarily on macroalgae and gelatinous macroplankton. Finally, I used exclusion cages, to examine whether predation-sensitive habitat shifts by megagrazers (green turtles, dugongs) transmitted a behavior-mediated trophic cascade (BMTC) between sharks and seagrasses. In general, data were consistent with predictions of a behavior-mediated trophic cascade. Megaherbivore impacts on seagrasses were large only in the microhabitat where megaherbivores congregate to reduce predation risk. My study highlights the importance of large herbivores in structuring seagrass communities and, more generally, suggests that roving top predators likely are important in structuring communities - and possibly ecosystems - through nonconsumptive pathways. 


\section{TABLE OF CONTENTS}

CHAPTER

PAGE

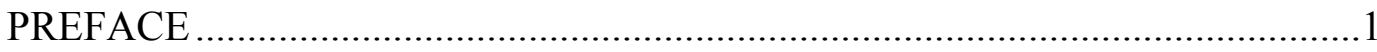

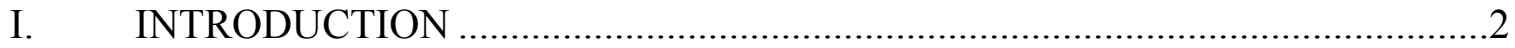

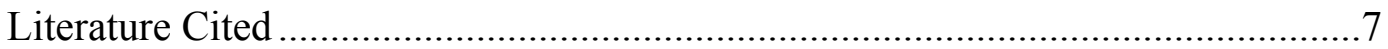

II. SPATIAL PATTERN IN SEAGRASS STOICHIOMETRY INDICATES

BOTH N-LIMITED AND P-LIMITED REGIONS OF AN ICONIC

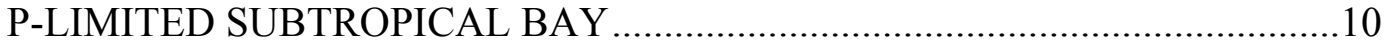

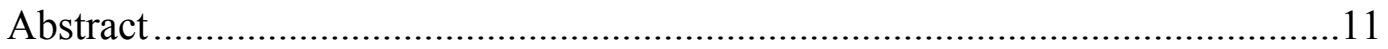

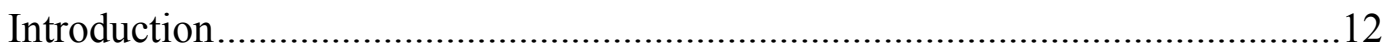

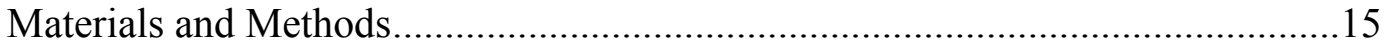

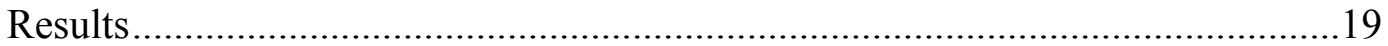

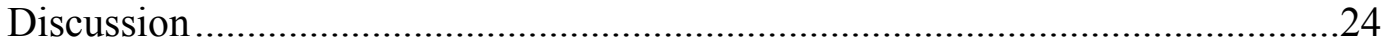

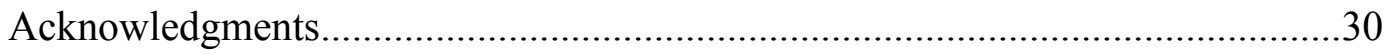

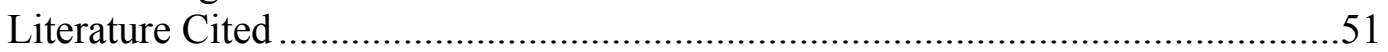

III. FEEDING PREFERENCES OF HERBIVORES IN A RELATIVELY

PRISTINE SUBTROPICAL SEAGRASS ECOSYSTEM ..................................55

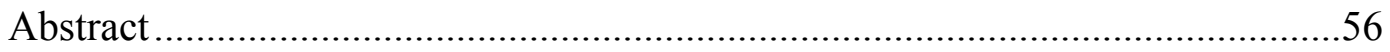

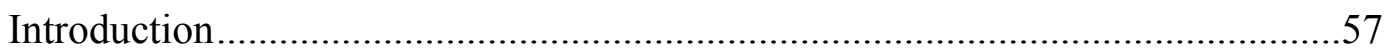

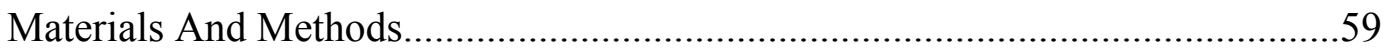

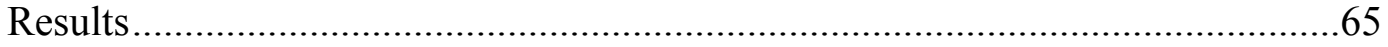

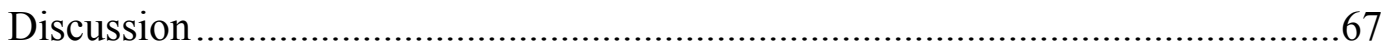

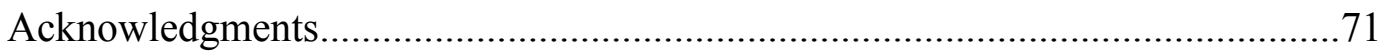

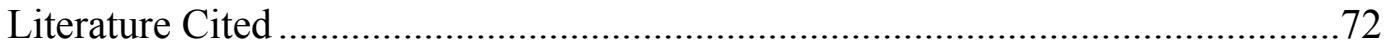

IV. DIVERSITY IN TROPHIC INTERACTIONS OF GREEN SEA TURTLES CHELONIA MYDAS ON A RELATIVELY PRISTINE

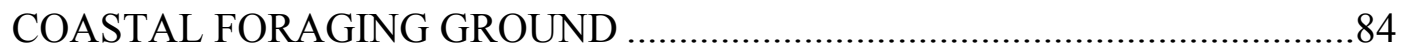

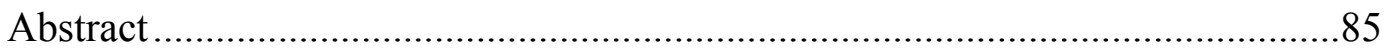

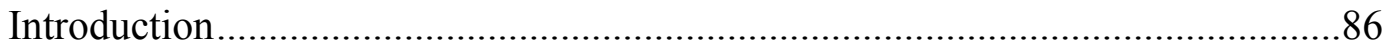

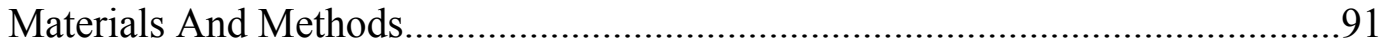

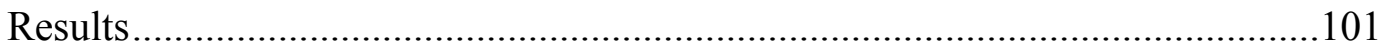

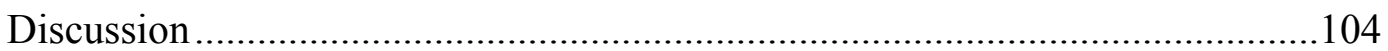

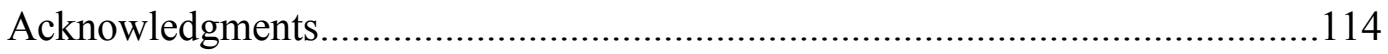

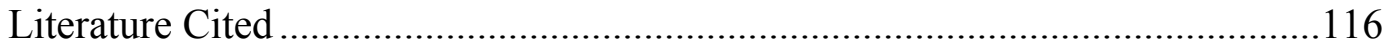

V. PATTERNS OF TOP-DOWN CONTROL OF A SEAGRASS

ECOSYSTEM: COULD A ROVING PREDATOR INDUCE A

BEHAVIOR-MEDIATED TROPHIC CASCADE? ………...........................130

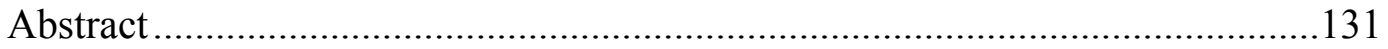




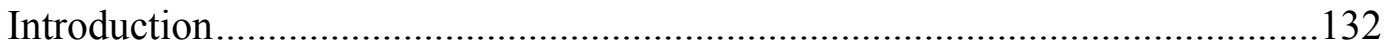

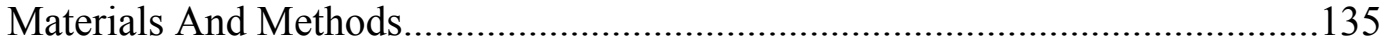

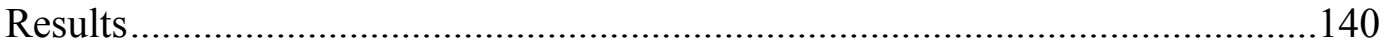

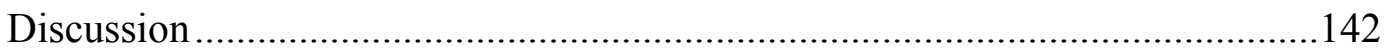

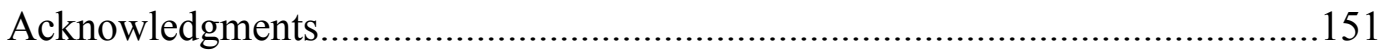

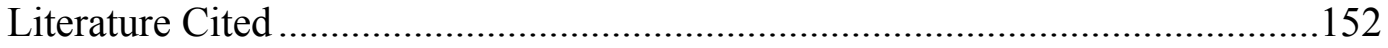

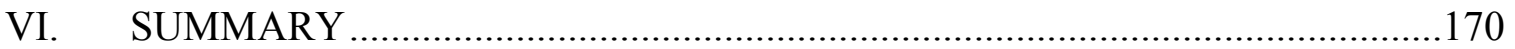

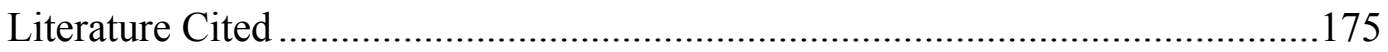

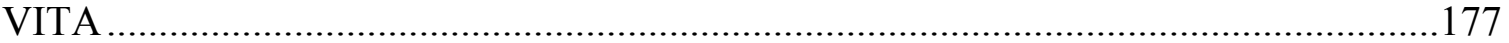




\section{LIST OF TABLES}

TABLE

PAGE

\section{CHAPTER II}

1 Bottom cover of seagrasses at 475 sites in Shark Bay, Western Australia. Values are based on averages of three subplots per site. Med. = Median, $\mathrm{FO}=$ Frequency of Occurrence

2a Differences in phosphorus concentration (\%P) among co-occurring seagrass species and epiphytes. Numbers above the diagonal represent the difference in phosphorus content of the species in the first column minus the species across the top (e.g. \%P of $\mathrm{Aa}-\% \mathrm{P}$ of $\mathrm{Psp}=-0.006)$. Numbers below the diagonal are sample sizes. $\mathrm{Aa}=$ Amphibolis antarctica, $\mathrm{Ca}=$ Cymodocea angustata, Epi = epiphytes, $\mathrm{Ho}=$ Halophila ovalis, $\mathrm{Hs}=$ Halophila spinulosa $\mathrm{Hu}=$ Halodule uninervis. $\mathrm{Psp}=$ Posidonia $\mathrm{sp}$ (primarily $P$. australis), $\mathrm{Si}=$ Syringodium isoetifolium. $* \mathrm{P} \leq 0.05$, $* * \mathrm{P} \leq 0.01, * * * \mathrm{P} \leq 0.001, \mathrm{NS}=$ not significant $(\mathrm{P}>0.05)$

$2 \mathrm{~b}$ Differences in nitrogen concentration $(\% \mathrm{~N})$ among co-occurring seagrass species and epiphytes (above the diagonal). Numbers above the diagonal represent the difference in nitrogen content of the species in the first column minus the species across the top (e.g. $\% \mathrm{~N}$ of $\mathrm{Aa}-\% \mathrm{~N}$ of $\mathrm{Psp}=$ - 0.273). Numbers below the diagonal are sample sizes

2c Differences in N:P among co-occurring seagrass species and epiphytes (above the diagonal). Numbers above the diagonal represent the difference in N:P of leaf tissues of the species in the first column minus the species across the top (e.g. N:P of $\mathrm{Aa}-\mathrm{N}: \mathrm{P}$ of Psp $=-4.6$ ). Numbers below the diagonal are sample sizes

3 Effects of region, distance to the Indian Ocean, depth, and the interaction of region and distance on N:P. Non-significant interactions $(P>0.10)$ were removed from final models

\section{CHAPTER III}

1 Relationship between estimated proportion of leaf area removed (i.e. proportion grazed at all * mean area removed when grazed), mean $\mathrm{C}: \mathrm{N}$, and mean $\mathrm{C}: \mathrm{P}$ content of seagrass species. Aa $=$ Amphibolis antarctica, $\mathrm{Ca}=$ Cymodocea angustata, $\mathrm{Hu}=$ Halodule uninervis, $\mathrm{Ho}=$ Halophila ovalis, $\mathrm{Hs}=$ Halophila spinulosa, $\mathrm{Pa}=$ Posidonia australis 


\section{CHAPTER IV}

1 Chelonia mydas. Estimated diet compositions of green turtles in Shark Bay, Western Australia, based on 3 assumptions about isotopic discrimination factors. Two sets of MixSir, a Bayesian-mixing model, were used. Skin tissue taken from the filler was analyzed in both sets. Seagrass was run as a resource pool without epiphytes in Set 1 but with epiphytes (epi) in Set 2. Isotopic values of potential food sources used in models: algae $\left(\delta^{13} \mathrm{C}=-15.55 \pm 2.61 ; \delta^{15} \mathrm{~N}=3.52 \pm 0.75\right)$, seagrass $\left(\delta^{13} \mathrm{C}=-9.41 \pm 1.32\right.$; $\delta^{15} \mathrm{~N}=0.77 \pm 1.62$ ), gelatinous macroplankton (gel. macropl.) combined for $<60 \mathrm{~cm}$ curved carapace length $(\mathrm{CCL})\left(\delta^{13} \mathrm{C}=-17.68 \pm 1.40 ; \delta^{15} \mathrm{~N}=\right.$ $7.24 \pm 0.56)$, gel. macropl. in summer $\left(\delta^{13} \mathrm{C}=-17.89 \pm 0.68 ; \delta^{15} \mathrm{~N}=6.82\right.$ $\pm 0.65)$, gel. macropl. in winter $\left(\delta^{13} \mathrm{C}=-19.27 \pm 0.27 ; \delta^{15} \mathrm{~N}=7.58 \pm 0.35\right)$. Values are medians with 5 th and 95 th percentiles in parentheses

2 Chelonia mydas. MixSir predicted diet compositions for extreme individual turtles (animals selected at extreme range of the carbon and nitrogen spectrums to encompass all possible values) based on discrimination factors of juvenile green turtles (Seminoff et al. 2006b) and juvenile loggerhead turtles (Reich et al. 2008). Values are medians with 5 th and 95 th percentiles in parentheses U: unclassed; M: male; Gel. macropl.: gelatinous macroplankton

\section{CHAPTER V}

1 Factors influencing the density of seagrasses in edge microhabitats

2 Statistical comparison of nutrient content of three species of fast-growing seagrasses in exclosures and control sites within edge microhabitats 


\section{LIST OF FIGURES}

FIGURE

PAGE

\section{CHAPTER II}

1 World and Bay map with Eastern Gulf, Western Gulf, and Northern regions outlined, and major landmarks.

2 Seagrass taxa diversity across Shark Bay from both summer and winter sampling effort, (a) and average abundances of seagrass species across Shark Bay (b) Amphibolis antarctica, (c) Posidonia sp., (d) Cymodocea angustata, (e) Halophila ovalis, (f) Halophila spinulosa, (g) Halodule uninervis, (h) Syringodium isoetifolium. Positions of the symbols indicate sampling locations. Insets show frequency histograms of species richness (a) or percent cover (b-h)

3 Phosphorus (a) and nitrogen (b) content of seagrass and epiphytes in Shark Bay, Australia during warm season. Boxes with the same letter indicate no significant differences at $\mathrm{P}<0.05$ for Tukey's test. Sample sizes are provided above Panel $a$. Aa = Amphibolis antarctica, $\mathrm{Ca}=$ Cymodocea angustata, Epi $=$ epiphytes, $\mathrm{Ho}=$ Halophila ovalis, $\mathrm{Hs}=$ Halophila spinulosa $\mathrm{Hu}=$ Halodule uninervis. $\mathrm{Psp}=$ Posidonia $\mathrm{sp}$ (primarily $P$. australis), $\mathrm{Si}=$ Syringodium isoetifolium

$4 \quad$ Ratios of C:N (a), C:P (b), and N:P (c) for seven species of seagrass and epiphytes in Shark Bay, Australia during warm season. Boxes with the same letter indicate no significant differences at $\mathrm{P}<0.05$ for Tukey's test. Sample sizes are provided above Panel $a . \mathrm{Aa}=$ Amphibolis antarctica, $\mathrm{Ca}=$ Cymodocea angustata, Epi = epiphytes, Ho = Halophila ovalis, Hs = Halophila spinulosa $\mathrm{Hu}=$ Halodule uninervis. $\mathrm{Psp}=$ Posidonia $\mathrm{sp}$ (primarily $P$. australis), $\mathrm{Si}=$ Syringodium isoetifolium .....

5 Regional variation in the influence of distance from the Indian Ocean on N:P ratios. * Western Gulf, $>=$ Northern Region, $\square=$ Eastern Gulf. Values above the dashed line suggest P-limitation while those below the line suggest N-limitation. See Table 3 for statistical results.

$6 \quad$ Variation among $(a)$ regions and $(b)$ with distance from the Indian Ocean in $\mathrm{N}: \mathrm{P}$ ratios of seagrasses in Shark Bay. Only species with significant main effects and no significant interaction between region and distance are included (see Table 3)

7 Isopleth of nutrient availability. Blue represents Nitrogen limitation, Red represents Phosphorus limitation, Regions plotted in white show no N:P 
values consistent with nutrient limitation. "+" symbols represent sample sites used for kriging map generation

\section{CHAPTER III}

1 Interspecific variation in a) $\mathrm{C}: \mathrm{N}$ and b) $\mathrm{C}: \mathrm{P}$ ratios of seagrasses collected for feeding preference trials. Error bars are $+/-$ SE. Bars labeled with the same letter are not statistically different from one another. Note, that lower values should indicate species of greater quality from an herbivores perspective (i.e. higher relative $\mathrm{N}$ or $\mathrm{P}$ content). Seagrass species are arranged along the $\mathrm{X}$-axis based on leaf turnover rates from slowest to fastest. Aa $=$ Amphibolis antarctica, $\mathrm{Ca}=$ Cymodocea angustata, $\mathrm{Hu}=$ Halodule uninervis, $\mathrm{Ho}=$ Halophila ovalis, $\mathrm{Hs}=$ Halophila spinulosa, $\mathrm{Pa}=$ Posidonia australis

2 a) Proportion of lines with at least some grazing on seagrasses during 2007 trials in interior microhabitats. b) Proportion of leaf area removed for lines and species that experienced at least some grazing of at least one serving. Bars with the same letter are not significantly different. Error bars are $+/-\mathrm{SE}$. Seagrass species are arranged along the $\mathrm{X}$-axis based on leaf turnover rates from slowest to fastest. Aa $=$ Amphibolis antarctica, $\mathrm{Ca}=$ Cymodocea angustata, $\mathrm{Hu}=$ Halodule uninervis, $\mathrm{Ho}=$ Halophila ovalis, $\mathrm{Hs}=$ Halophila spinulosa, $\mathrm{Pa}=$ Posidonia australis.

3 a) Proportion of lines with at least some grazing on seagrasses during 2009 trials in interior, edge and deep microhabitats. There was no detectable effect of habitat or the interaction of habitat and species. b) Proportion of leaf area removed for lines and species that experienced at least some grazing of at least one serving. There was no detectable effect of habitat or the interaction of habitat and species. Bars with the same letter are not significantly different. Error bars are $+/-$ SE. Seagrass species are arranged along the $\mathrm{X}$-axis based on leaf turnover rates from slowest to fastest. $\mathrm{Aa}=$ Amphibolis antarctica, $\mathrm{Ca}=$ Cymodocea angustata, $\mathrm{Hu}=$ Halodule uninervis, $\mathrm{Ho}=$ Halophila ovalis, $\mathrm{Hs}=$ Halophila spinulosa, $\mathrm{Pa}=$ Posidonia australis.

\section{CHAPTER IV}

1 Location of the study site (*) in the Eastern Gulf of Shark Bay, Western Australia. Points represent capture location of green turtles sampled for stable isotopic composition. White points: captures in the nearshore habitat; black points: captures in the offshore seagrass bank habitat

2 Chelonia mydas. Size distribution of individuals sampled for stable isotopic analysis. 
3 Isotopic values of individual green turtles, their potential food resources, and representative herbivores in Shark Bay, Australia

4 Chelonia mydas. Influence of curved carapace length (CCL, in $\mathrm{cm})$ on

(a) $\delta^{13} \mathrm{C}$ and (b) $\delta^{15} \mathrm{~N}$ values

\section{CHAPTER V}

1 The study was conducted in the Eastern Gulf of Shark Bay, Western Australia (a). Exclosure and control plots were established on two banks within the long-term study area. The location of exclosures is denoted with a closed circle. Control sites are open circles

2 Temporal variation in the densities of Halodule uninervis within interior exclosures and control plots. Error bars represent $\pm \mathrm{SE}$

3 At the initiation of experiments in edge microhabitats, seagrasses were relatively sparse and closely cropped (top). After 600 days, seagrass heights and densities had increased (below)

$4 \quad$ Initial and ending shoot densities of Cymodocea angustata and Halodule uninervis in exclosures and control plots. Bars with different letters are significantly different based on post-hoc Tukey's tests. Error bars represent $\pm \mathrm{SE}$

5 Heights of seagrasses at the conclusion of experiments. Error bars represent \pm SE. ${ }^{* * *} \mathrm{P}<0.0001 ; \mathrm{NS}=$ not significant

$6 \quad$ Nutrient content a) $\mathrm{C}: \mathrm{N}$, b) $\mathrm{C}: \mathrm{P}$, c) $\mathrm{N}: \mathrm{P}$ of seagrass blades in exclosures and controls at the conclusion of experiments. Error bars represent $\pm \mathrm{SE} . * * * \mathrm{P}<$ $0.001,{ }^{* *} \mathrm{P}<0.01, * \mathrm{P}<0.05, \mathrm{NS}=$ not significant

7 Proportion of remaining C. angustata $(\mathrm{n}=10$ plots) and H. uninervis $(\mathrm{n}=4$ plots) blades remaining after removal of exclosures. Error bars represent $\pm \mathrm{SE}$. Symbols with different letters are significantly different based on Tukey's post-hoc tests. Letters above symbols are $C$. angustata and those below symbols are $H$. uninervis

8 Halos of grazing (white arrows) inside exclosures suggest that green turtles are at least partially responsible for reduced seagrass biomass in edge microhabitats 


\section{PREFACE}

The following chapters have been published or accepted for publication and have been formatted for those publications.

\section{CHAPTER II}

Burkholder DA, Fourqurean JW, and MR Heithaus (in press) Spatial pattern in seagrass stoichiometry indicates both $\mathrm{N}$-limited and P-limited regions of an iconic P-limited subtropical bay. Mar Ecol Prog Ser

DOI:10.3354/meps 10042

Reproduced with kind permission by Marine Ecology Progress Series. A version of this manuscript is scheduled for publication in Marine Ecology Progress Series. DOI: $10.3354 /$ meps 10042

\section{CHAPTER III}

Burkholder DA, Heithaus MR, and JW Fourqurean (in press) Feeding preferences of herbivores in a relatively pristine subtropical seagrass ecosystem. Mar Fresh Res

Reproduced with kind permission by Marine and Freshwater Research. A version of this manuscript is scheduled for publication in Marine and Freshwater Research, Issue 10. http://www.publish.csiro.au/?nid=126

\section{CHAPTER IV}

Burkholder DA, Heithaus MR, Thomson JA, and JW Fourqurean (2011) Diversity in trophic interactions of green sea turtles Chelonia mydas on a relatively pristine coastal foraging ground. Mar Ecol Prog Ser 439: 277293. DOI: $10.3354 /$ meps09313

Reproduced with kind permission by Marine Ecology Progress Series. A version of this manuscript has been published in Marine Ecology Progress Series, Issue 439. DOI: 10.3354/meps09313 
CHAPTER I

INTRODUCTION 
Trophic downgrading of ecosystems - the loss of large-bodied herbivores and/or top predators - has been associated with large-scale changes in terrestrial, freshwater, and marine ecosystems around the world (Estes et al. 2011). Trophic cascades initiated by the removal of top predators have been well studied in small scale and experimental settings. These studies show that predators can structure primary producer community structure, biomass, and nutrient composition indirectly both through removing prey individuals (predation or direct killing) and inducing behavioral changes in herbivores (e.g., Pace et al. 1999, Preisser et al. 2005, Schmitz 2006, Heithaus et al. 2008a). There remain, however, important gaps in our understanding of the prevalence, mechanisms, and context-dependence of herbivore-mediated indirect impacts of predators on primary producer communities. Indeed, recent studies have raised questions about whether smallscale experiments might scale up to diverse ecosystems and whether vertebrate predators may be less likely to trigger trophic cascades than insect predators that are the model in many experiments (Shurin and Seabloom 2005). Also, although non-consumptive (risk) effects are often cited as being stronger in marine habitats than freshwater or terrestrial ones (e.g., Preisser et al. 2005), the lack of studies in large-scale marine ecosystems that include large-bodied taxa raises questions as to whether this result may be driven to some extent by the scale and taxa of previous studies.

Seagrasses are important benthic primary producers and form extensive habitats in many coastal areas from the tropics to cool temperate waters. Seagrass ecosystems are highly productive and are characterized by primary productivity rates comparable to agricultural fields in annual primary production (Zieman and Wetzel 1980). Seagrass ecosystems also provide critical habitat for a multitude of species including many of 
economic importance (Short and Wyllie-Echeverria 1996, Heck et al. 2003). Also, recent studies have also found seagrass communities are an important global carbon sink (Duarte et al. 2010, Fourqurean et al. 2012). Despite their importance, seagrass ecosystems are one of the most threatened ecosystems on the planet today, estimated to be lost at a rate of $110 \mathrm{~km}^{2} \mathrm{yr}^{-1}$ since 1980 (Waycott et al. 2009). Seagrass ecosystems are also threatened by trophic downgrading (Estes et al. 2011). Indeed, populations of large-bodied herbivores and their predators have declined dramatically, potentially disrupting important top-down processes (e.g., Jackson et al. 2001, Heck and Valentine 2006). Therefore, understanding factors driving the dynamics of seagrass ecosystems is an important step to managing, and in some cases restoring, these important coastal ecosystems.

Recent work has demonstrated that megagrazers (e.g., green turtle, Chelonia mydas and dugong, Dugong dugon) can impact seagrass biomass, production, nutrient cycling, and community structure (Thayer 1982, de Iongh et al. 1995, Bjorndal 1997, Aragones \& Marsh 2000, Masini et al. 2001, Moran \& Bjorndal 2005, Lal et al. 2010). It remains unclear, however, whether these impacts are representative of ecosystem dynamics under natural conditions (e.g., Heck and Valentine 2006, 2007). Indeed, most studies to date have occurred in communities that have been heavily modified by humans (Jackson 1997, Heck and Valentine 2007, Jackson et al. 2001), including populations of both megaherbivores and their potential predators (sharks). Indeed, Jackson et al. (2001) suggested that seagrass communities historically would have had much lower biomass and a vastly different community structure because of unrestricted grazing by herbivores. The structure of historical seagrass communities, however, also may have been structured 
by numerical and behavioral responses of large herbivores to their predators (see Heithaus et al. 2007, 2008a,b); a possibility that is largely overlooked. Therefore, conservation targets and pristine ecosystem structure currently envisaged could be the result of a "shifting baseline" rather than a representation of ecosystem structure that would have existed when large herbivores and their predators were found in preexploitation population densities.

The goal of my dissertation is to investigate the potential for top down pressures by large bodied herbivores (dugong and green sea turtle) and a top predator (tiger shark) to structure a pristine seagrass ecosystem. I conducted this work in Shark Bay, Western Australia which has been used as a model system to elucidate the ecological role of the tiger shark (Galeocerdo cuvier), a roving predator, in a seagrass ecosystem since 1997 (Heithaus et al. 2007a). Shark Bay's diverse and extensive seagrass community (Walker et al. 1988) supports large, intact populations of large grazers like dugongs (Dugong dugon) (Preen et al. 1997) and green sea turtles (Chelonia mydas) (Heithaus et al. 2005) and provides an important and unique opportunity to examine the ecological roles of large grazers and their predators in the absence of major anthropogenic impacts (Heithaus et al. 2007b, 2008, 2009).

I begin by investigating the dynamics of Shark Bay's seagrasses across multiple spatial scales. In Chapter II, I quantify large-scale spatial variation in seagrass communities in Shark Bay, and use N:P ratios to investigate patterns of nutrient limitation across the bay.

Because forage preferences of herbivores can be critical to determining their impacts on primary producer communities, in Chapter III I present results of a forage 
choice experiment. Feeding patterns of dugongs in Shark Bay are well-studied (e.g., Wirsing 2007), but those of the other megaherbivore in Shark Bay, green turtles, are not. Therefore, in Chapter IV, I use stable isotopic analysis of turtle tissues combined with animal borne video and stomach content analysis to examine the diet of these animals. Finally in Chapter V, I experimentally present an investigation of whether spatial variation in megagrazer impacts on seagrass community structure, density, and nutrient composition were consistent with a priori predictions of a hypothesized behaviormediated trophic cascade (BMTC) initiated by tiger sharks (Galeocerdo cuvier) and mediated by large grazers.

Overall, this work provides one of the first large scale examinations of a potential BMTC involving large bodied taxa. More specifically, this work provides important insights into the dynamics of a pristine seagrass community and helps to establish ecological baselines for these crucial ecosystems. 


\section{LITERATURE CITED}

Aragones LV, Marsh H (2000) Impact of dugong grazing and turtle cropping on tropical seagrass communities. Pacific Conservation Biology. 5: 277-288

Bjorndal KA (1997) Foraging ecology and nutrition of sea turtles. In The biology of sea turtles (eds. Lutz PL, Musick JA), pp. 199-231. Boca Raton: CRC Press

de Iongh HH, Wenno BJ, Meelis E (1995) Seagrass distribution and seasonal biomass changes in relation to dugong grazing in the Moluccas, East Indonesia. Aquatic Botany 50: 1-19

Duarte CM, Marbà N, Gacia E, Fourqurean JW, Beggins J, Barrón C, Apostolaki ET (2010) Seagrass community metabolism: Assessing the carbon sink capacity of seagrass meadows, Global Biogeochemical Cycles, 24, GB4032, doi:10.1029/2010GB003793

Estes JA, Terborgh J, Brashares JS, Power ME, Berger J, Bond WJ, Carpenter SR, Essington TE, Holt RD, Jackson JBC, Marquis RJ, Oksanen L, Oksanen T, Paine RT, Pikitch EK, Ripple WJ, Sandin SA, Scheffer M, Schoener TW, Shurin JB, Sinclair ARE, Soulé ME, Virtanen R, Wardle DA (2011) Trophic downgrading of plant earth. Science 333 (6040): 301-306

Fourqurean JW, Duarte CM, Kennedy H, Marba N, Holmer M, Mateo MA, Apostolaki ET, Kendrick GA, Krause-Jensen D, McGlathery KJ, Serrano O (2012) Seagrass ecosystems as a globally significant carbon stock. Nature Geoscience 5: 505-509

Heck KL Jr., Orth RJ, Hays CG (2003) Critical evaluation of the nursery role hypothesis for seagrass meadows. Marine Ecology Progress Series. 253:123-136

Heck KL, Valentine JF (2006) Plant-herbivore interactions in seagrass meadows. Journal of Experimental Marine Biology and Ecology 330: 420-436

Heck KL, Valentine JF (2007) The primacy of top-down effects in shallow benthic ecosystems. Estuaries and Coasts 30: 371-381

Heithaus MR, Frid A, Wirsing A, Bejder L, Dill LM (2005) The biology of green and loggerhead turtles under risk from tiger sharks at a foraging ground. Marine Ecology Progress Series 288: 285-294

Heithaus MR, Wirsing AJ, Dill LM (2007) Species interactions and marine conservation: Lessons from an undisturbed ecosystem. Israel Journal of Ecology and Evolution $53: 355-370$ 
Heithaus MR, Frid A, Wirsing AJ, Worm B (2008a) Predicting ecological consequences of marine top predator declines. Trends in Ecology and Evolution 23: 202-210

Heithaus MR, Wirsing AJ, Thomson J, Burkholder DA (2008b) A review of lethal and non-lethal effects of predators on adult marine turtles. Journal of Experimental Marine Biology and Ecology 356: 43-51

Heithaus MR, Wirsing AJ, Burkholder DA, Thomson J, Dill LM (2009) Towards a predictive framework for predator risk effects: the interaction of landscape features and prey escape tactics. Journal of Animal Ecology 78: 556-562

Jackson JBC (1997) Reefs since Columbus. Coral Reefs 16: 523-532

Jackson JBC, Kirby MX, Berger WH, Bjorndal KA, Botsford LW, Borque BJ, Bradbury RH, Cooke R, Erlandson J, Estes JA, Hughes TP, Kidwell S, Lange CB, Lenihan HS, Pandolfi JM, Peterson CH, Steneck RS, Tegner MJ, Warner RR (2001) Historical overfishing and the recent collapse of coastal ecosystems. Science 146, $629-638$

Lal A, Arthur R, Marba N, Lill AWT, Alcoverro T (2010) Implications of conserving an ecosystem modifier: Increasing green turtle (Chelonia mydas) densities substantially alters seagrass meadows. Biological Conservation 143: 2730-2738

Masini RJ, Anderson PK, McComb AJ (2001) A Halodule-dominated community in a subtropical embayment: physical environment, productivity, biomass, and impact of dugong grazing. Aquatic Botany 71: 179-197

Moran KL, Bjorndal KA (2005) Simulated green turtle grazing affects structure and productivity of seagrass pastures. Marine Ecology Progress Series 305: 235-247

Pace ML, Cole JJ, Carpenter SR, Kitchell JF (1999) Trophic cascades revealed in diverse systems. Trends in Ecology and Evolution 14: 483-488

Preen AR, Marsh HD, Lawler IR, Prince RI, Shepherd R (1997) Distribution and abundance of dugongs, turtles, dolphins and other megafauna in Shark Bay, Ningaloo Reef and Exmouth Gulf, Western Australia. Wildlife Research 24(2): $185-208$

Preisser EL, Bolnick DI, Benard MF (2005) Scared to death? The effects of intimidation and consumption in predator-prey interactions. Ecology 86:501-509

Schmitz OJ (2006) Predators have large effects on ecosystem properties by changing plant diversity, not plant biomass. Ecology 87(6): 1432-1437

Short FT, Wyllie-Echeverria S (1996) Natural and human-induced disturbance of 
seagrasses. Environmental Conservation 23: 17-27

Shurin JB, Seabloom EW (2005) The strength of trophic cascades across ecosystems: Predictions from allometry and energetics. Journal of Animal Ecology 74(6): 1029-1038

Thayer GW, Engel DW (1982) Evidence for short circuiting of the detritus cycle of seagrass beds by the green turtle Chelonia mydas. Journal of Experimental Marine Biology and Ecology 62 (2): 173-183

Walker DI, Kendrick GA, McComb AJ (1988) The distribution of seagrass species in Shark Bay, Western Australia, with notes on their ecology. Aquatic Botany 30: 305-317

Waycott M, Duarte CM, Carruthers TJB, Orth RJ, Dennison WC, Olyarnik S, Calladine A, Fourqurean JW, Heck Jr. KL, Hughes AR, Kendrick GA, Kenworthy WJ Short FT, Williams SL (2009) Accelerating loss of seagrasses across the globe threatens coastal ecosystems. Proceedings of the National Academy of Sciences. USA 106(30): 12377-12381

Wirsing AJ, Heithaus MR, Dill LM (2007) Can you dig it? Use of excavation, a risky foraging tactic, by dugongs is sensitive to predation danger. Animal Behavior 74: 1085-1091

Zieman JC, Wetzel RG (1980) Productivity in seagrasses: methods and rates. In: Phillips RC, McRoy CP (eds). Handbook of seagrass biology, an ecosystem prospective. Garland STPM, New York, pp 87-116 
CHAPTER II

SPATIAL PATTERN IN SEAGRASS STOICHIOMETRY INDICATES BOTH N-LIMITED AND P-LIMITED REGIONS OF AN ICONIC

P-LIMITED SUBTROPICAL BAY 


\begin{abstract}
I investigated seagrass species distribution and nutrient content in the iconic phosphorus-limited Shark Bay, Western Australia. I found the slower-growing, temperate species Amphibolis antarctica and Posidonia spp. had lower N and P content compared to the faster-growing tropical species Halodule uninervis, Syringodium isoetifolium, Cymodocea angustata, Halophila ovalis and Halophila spinulosa. Further, by comparing elemental content of different seagrass species at sites where species cooccurred, I was able to standardize seagrass elemental content across sites with different species composition. The standardization allowed us to make ecosystem-scale inferences about resource availability despite taxon-specific distributions and elemental content. I found a marked spatial pattern in N:P of seagrasses across the system, indicating that Plimitation occurred, despite calcium carbonate sediments, only in the most isolated portions of the bay. Large areas close to the mouth of the bay were either N-limited or were not limited by N- or P-availability. My results suggest that large-scale nutrient budgets may oversimplify our understanding of limiting factors in a system, resulting in management decisions that may have unforeseen effects on different areas within the same ecosystem.
\end{abstract}




\section{Introduction}

Estuaries and bays were once considered by biologists to be universally N-limited (despite the conclusions of Redfield 1958), but in the 1980s it became clear that systems with long water residence times and high N:P in freshwater runoff could be P-limited (Smith 1984, Howarth 1988). Shark Bay, a subtropical, hypersaline embayment in Western Australia, was one of the first coastal systems for which P limitation was asserted (Smith and Atkinson 1983, Smith 1984, Atkinson 1987). It was argued that little freshwater runoff, long water residence times and high rates of nitrogen fixation led to this P-limited state. Since that time, other coastal ecosystems with long water residence times have also been shown to be P-limited (e.g., coastal China, Harrison et al. 1990; the eastern Mediterranean, Krom et al. 1991; Florida Bay, Fourqurean et al. 1992; Moreton Bay, Australia, Wulff et al. 2011).

Phosphorus limitation is commonly reported in systems with sediments composed chiefly of calcium carbonate, which is the case for Shark Bay (Atkinson 1987, Walker and Woelkerling 1988). Phosphorus limitation has been attributed to the high phosphate binding capacity of carbonate sediments and the resultant low mobility of $\mathrm{P}$ in carbonate systems (de Kanel and Morse 1978). However, not all carbonate ecosystems are P-

limited, and in fact adjacent $\mathrm{N}$ - and P-limited regions in carbonate sediment ecosystems have been identified (Fourqurean and Zieman 2002) suggesting that the carbonate content of sediments does not alone determine whether $\mathrm{N}$ or $\mathrm{P}$ will limit benthic primary production. The generality of this result, however, remains unclear. Given the observed $\mathrm{N}$-limited nature of many phytoplankton communities offshore of Shark Bay (Hanson et al. 2005) and the strong tidal mixing of nearshore ocean waters into Shark Bay, it is likely 
that regions of Shark Bay closer to the mouth with lower water residence times could be $\mathrm{N}$, rather than $\mathrm{P}$, limited despite carbonate sediments.

Understanding the nature of nutrient limitation in coastal water bodies is critical to their management. Coastal ecosystems in the United States and around the world have been modified dramatically by rapidly increasing human populations and anthropogenic impacts (e.g., Lotze et al. 2006, Orth et al. 2006). Among the most prevalent anthropogenic impacts is nutrient pollution, which can drastically alter the structure of ecological communities (Nixon 1995). As different management strategies are employed to control the discharge of $\mathrm{N}$ and $\mathrm{P}$, efficient management requires identifying the limiting nutrient of a system.

Nutrient-limited estuaries and bays often have relatively transparent water columns and support seagrasses and other benthic primary producers in areas where sufficient light can reach unconsolidated sediments. Seagrasses are important benthic primary producers and form critical habitats in many coastal ecosystems. Seagrass ecosystems are highly productive habitats, providing primary productivity rates comparable to agricultural fields in annual primary production (Zieman and Wetzel 1980). Seagrass ecosystems also provide critical habitat for a multitude of species including many of economic importance (Short and Wyllie-Echeverria 1996). Despite their importance, seagrass ecosystems are one of the most threatened ecosystems on the planet today, estimated to be lost at a rate of $110 \mathrm{~km}^{2} \mathrm{yr}^{-1}$ since 1980 (Waycott et al. 2009). The most often cited impact leading to decline in seagrass meadows around the world is reduced water quality, often driven by increases in the delivery of the limiting nutrient to the ecosystem (Short and Wyllie-Echeverria 1996, Orth et al. 2006). 
Because the ratios of elements in tissues of marine primary producers respond to the relative availability of nutrients and light, $\mathrm{N}: \mathrm{P}$ ratios of primary producer biomass can be used to assess the relative importance of $\mathrm{N}$ and $\mathrm{P}$ in limiting biomass and productivity (Redfield 1958). While phytoplankton communities can be advected around an ecosystem, obscuring the spatial pattern in the availability of different resources, benthic primary producers are fixed in place and therefore can be used to integrate nutrient availability over long time periods. Consequently, spatial patterns in the N:P ratios of benthic primary producers have been used to deduce the landscape of resource limitation for benthic primary producers within ecosystems (e.g., Fourqurean et al. 1992, Fourqurean and Zieman 2002, Johnson et al. 2006).

In this paper, I revisit the question of P limitation in Shark Bay, the iconic Plimited coastal ecosystem, by analyzing spatial patterns in the N:P of the bay's seagrasses and epiphyte communities. Shark Bay supports some of the world's most extensive seagrass meadows, covering approximately $4000 \mathrm{~km}^{2}$, and with 12 species of seagrasses it is also one of the most diverse seagrass ecosystems (Walker et al. 1988). Given that no single species of seagrass is distributed across all of the seagrass meadows of Shark Bay and that seagrasses in other regions have species-specific differences in elemental content (Campbell and Fourqurean 2009), I aimed to describe the distributions of the most common seagrass taxa across the system and determine whether there were taxonspecific differences in N:P. I then analyzed the large-scale spatial pattern in N:P of seagrasses across the $13,000 \mathrm{~km}^{2}$ of Shark Bay to determine whether the relative importance of $\mathrm{N}$ and $\mathrm{P}$ as limiting nutrients varies across the system. 


\section{Materials and Methods}

Study Site

Shark Bay, Western Australia, is a 13,000 km² embayment located about $800 \mathrm{~km}$ north of Perth. It is a relatively shallow bay $(<15 \mathrm{~m}$ generally) that is divided by Peron Peninsula into an Eastern and Western Gulf (Figure 1). The Western Gulf features greater connectivity to waters of the Indian Ocean than the Eastern Gulf. Circulation to the southern portions of the Eastern Gulf, particularly Hamelin Pool, are further restricted by the shallow carbonate bank of the Faure Sill which runs from the eastern coast of Peron Peninsula to the mainland coast. For regional comparisons, I divided the study area into the 1) Western Gulf, defined as the area from the tip of Dirk Hartog Island to the tip of Peron Peninsula south, 2) the Eastern Gulf, defined as the area from the tip of Peron Peninsula east to the mainland and south, and 3) Northern Region, which was defined as the area north of the two Gulfs (Figure 1).

Seagrasses are broadly distributed across the bay and are particularly abundant in water shallower than $4 \mathrm{~m}$. Both the Eastern and Western Gulfs of Shark Bay and coastal waters in the Northern Region were surveyed for seagrass distribution and nutrient content. The diversity of seagrasses in Shark Bay is partly attributable to the overlap of temperate and tropical floras. Seagrasses of temperate origin are the most abundant. Amphibolis antarctica (Aa) is the most common species, followed by Posidonia australis. Posidonia coriacea, also of temperate origin, is less common. In the field I did not differentiate between these Posidonia species, so I will refer to Posidonia species (Psp) for the remainder of this paper, although $P$. australis was by far the most common Posidonia. Tropical seagrasses also occur within the study area but are confined to 
shallow sandy patches and deep water. These include Halophila ovalis (Ho), Halophila spinulosa (Hs), Halodule uninervis (Hu), Syringodium isoetifolium (Si), and Cymodocea angustata (Ca) (Walker et al. 1988).

\section{Field methods}

From 2007 to 2009 I surveyed seagrasses at 475 stations (Summer 2007, N = 168 sites, Winter 2007, N = 188 sites, Summer 2008, N = 123 sites, Winter 2008, N = 163 sites, Summer 2009, $N=179$ ). General sample locations were selected to distribute stations widely throughout Shark Bay. Specific stations were selected haphazardly by stopping the vessel after 5 minutes of travel time (at $c a$. $30 \mathrm{kph}$ ) between sites along predetermined routes. Each sampling site was surveyed either using snorkel or SCUBA. A $60 \mathrm{~cm} \times 60 \mathrm{~cm}$ quadrat with grid was dropped haphazardly off the side of the anchored vessel. Percent cover was estimated with a visual assessment of the quadrat for each seagrass species was recorded in the quadrat where it settled on the bottom, one observer made all visual assessments throughout the study for uniformity. The quadrat was then flipped end over end three times moving toward the front of the boat and visually sampled for percent seagrass cover for each species. The process was repeated for a third quadrat reading at each site. Data were averaged into a mean percent cover for each sample station. Water temperature, salinity (refractometer), water depth (vessel depth sounder) and GPS location were recorded at each site.

Seagrass samples were collected by hand at each site for elemental analysis. At least five shoots, and their roots/rhizome tissue were collected for each species at the sample station. All seagrass species encountered, even if they were not represented in the quadrat-sampling regime were collected for nutrient analysis. All samples were stored on 
ice in the field. Samples were immediately frozen to $-20^{\circ} \mathrm{C}$ upon return to shore. Samples remained frozen until they could be processed.

Sampling sites were visited once in the warm season (September - May), and once in the cold season (June - August). Species abundance is represented for sampling from both seasons. Seagrass nutrient limitation is most prevalent in the warm season during the period of highest seagrass primary production and resource use (Fourqurean et al. 2005, Walker and McComb 1988). Because even temperate seagrass species show peak growth rates during the warm season in Shark Bay (Walker and McComb 1988) I limited the elemental analyses to samples collected in the warm (high productivity) season.

\section{Laboratory Methods and Analysis}

Seagrass samples were thawed, rinsed in DI water, and each leaf was gently scraped with a razorblade to remove all epibiota. The epibiota were combined from all seagrass species collected at a site to obtain enough epiphyte material for analysis and were run separately from leaf tissue. The pooling procedure assumed that the elemental content of the epibionts was the same across seagrass species, but I did not test this assumption. I separated leaves from stems and belowground tissue (roots and rhizome) and restricted my analysis to leaf tissue of each species. Leaves from each of the five plants collected for each site were dried using a food dehydrator (Ezidri Ultra FD1000) for at least 24 hours. Once dry, samples were crushed into powder for analysis using mortar and pestle. Carbon (C) and nitrogen $(\mathrm{N})$ content of samples were measured using an elemental analyzer (Fisons NA1500) and phosphorus (P) content was measured using a dry-oxidation/acid hydrolysis method (Fourqurean et al. 1992) 


\section{Statistical Analyses}

I used ANOVA with Tukey's post-hoc tests on log-transformed data to test for mean differences in the elemental content of the seagrass taxa and epiphytes for all data pooled across the study area. Because differences in nutrient availability across the study could interact with different species distributions to lead to differences in mean elemental content among species, I further tested whether the elemental content of seagrass taxa and epiphytes differed predictably at sites where they co-occurred by using paired t-tests to test for significant pairwise differences.

Using the results of the comparisons of $\mathrm{N}: \mathrm{P}$ of seagrass taxa at sites where the taxa co-occur, I generated a standardized seagrass N:P ratio for each sampling station by using the observed value of N:P for each taxon, then adjusting each value by the average difference between that taxon and Amphibolis antarctica (Table 2c), the most widely distributed taxon, so that $\mathrm{N}: \mathrm{P}_{\text {standardized }}=$ mean $\left(\mathrm{N}: \mathrm{P}_{A a}, \mathrm{~N}: \mathrm{P}_{P s p}-4.6, \mathrm{~N}: \mathrm{P}_{H u}, \mathrm{~N}: \mathrm{P}_{H o}+8.5\right.$, $\mathrm{N}: \mathrm{P}_{H s}+7.9, \mathrm{~N}: \mathrm{P}_{C a}-5.6, \mathrm{~N}: \mathrm{P}_{S i}$; see Results). To visualize the pattern in $\mathrm{N}: \mathrm{P}_{\text {standardized }}$ across the study area, I generated a contour plot using a kriging routine (Surfer v9, Golden Software, Inc.) to interpolate between my sampling locations. My kriging routine assumed a linear variogram with a slope of 1 and no anisotropy and calculated predicted values using up to 64 nearest neighbors within $60 \mathrm{~km}$ of each grid position. I calculated the root mean square error (RMSE) of this kriged map as a measure of the reliability of the depicted pattern

I used a general linear model to explore the influences of water depth (derived from readings from the vessel's depth sounder), distance from the Indian Ocean, and region (Northern, Eastern Gulf, Western Gulf) on N:P ratios of each species. I also 
included the interaction of region and distance in models because of differences in water flow among regions. The interaction was removed for species if $\mathrm{P}>0.10$. Main effects were retained in final models regardless of significance level.

\section{Results}

Samples were collected from 475 stations for point samples of seagrass species composition, percent cover and nutrient content. Of these, 470 were sampled in the warm season (daily temperature range $19.5-31.5^{\circ} \mathrm{C}$ ) and 351 were sampled in the cold season (daily temperature range $15.8-23.2^{\circ} \mathrm{C}$ ). Variation in winter vs summer sample site numbers resulted from mechanical/weather constraints during the winter months in 2008 limiting sampling in some areas. Summer sampling with the Department of Environment and Conservation in 2009 allowed for the expansion of sample sites into locations, including Hamelin Pool, that were otherwise inaccessible because of permit regulations and vessel restrictions. Salinity ranged from 25 ppt (warm season 2008 in Useless Loop) to 65 ppt (warm season 2009 in Hamelin Pool).

Seven seagrass taxa were commonly encountered throughout the study area. There was, however, a large amount of variation in taxa richness across the bay as well as the frequency of occurrence and cover of seagrass species (Table 1, Figure 2). Stations where seagrass was absent were concentrated south of the Faure Sill, especially in the hypersaline Hamelin Pool. At more than half of the stations where seagrass was present, there was only a single species (Figure 2a). There were, however, several hotspots of diversity, where up to six taxa of seagrass were found at individual stations, including in the central Eastern Gulf where there are numerous offshore seagrass banks $(<4 \mathrm{~m})$ 
surrounded by deeper channels $(7-11 \mathrm{~m}$ depth) and along the shallow coastal waters of the Northern Region. Several coastal areas in the southern Western Gulf and along the northeast Western Gulf had four or five taxa of seagrass at individual stations, but these concentrated in nearshore areas. Stations in the middle of the Gulf generally had only a single taxon.

Amphibolis antarctica was the most widespread species and was generally found in dense stands, usually with mean cover exceeding 90\%, (Figure 2b) and canopy heights up to $130 \mathrm{~cm}$ tall. Amphibolis antarctica was notably absent from Hamelin Pool and was encountered less often in deeper waters of Freycinet Basin in the southern Western Gulf, and restricted areas including Lharidon Bight in the Eastern Gulf and Useless Loop in the Western Gulf. The other temperate species in Shark Bay, Posidonia spp., were absent from large portions of the southern areas of the Eastern and Western Gulf (Figure 2c), but were found (primarily P. australis) in some dense stands north of the Faure Sill, in northern portions of the Northern Region and along southern Dirk Hartog Island. Tropical species, with the exception of Halodule uninervis, were generally distributed patchily and were found in low percent cover when encountered (Figure 2dh). Most tropical species, however, were found along the northern coast of the Northern Region and associated with the offshore seagrass banks of the central Eastern Gulf. Although generally occurring in sparse stands, H. uninervis was widely distributed in the bay including in the more restricted waters of the southern Eastern Gulf. It was, however, absent from most of the coast of Dirk Hartog Island (Figure 2g).

There was significant variation among taxa in phosphorus content $\left(\mathrm{F}_{7,1516}=115.2\right.$, $\mathrm{P}<0.0001$; Figure $3 \mathrm{a})$ and nitrogen content $\left(\mathrm{F}_{7,1516}=271.7, \mathrm{P}<0.0001\right.$; Figure $\left.3 \mathrm{~b}\right)$. 
Halophila ovalis had the highest phosphorus content, followed by H. spinulosa and Halodule uninervis. Amphibolis antarctica and epiphytes had the lowest phosphorus and nitrogen content. Cymodocea angustata had the highest nitrogen content, followed by Halodule uninervis, Halophila ovalis and Syringodium isoetifolium.

The ratios of $\mathrm{C}: \mathrm{N}\left(\mathrm{F}_{7,1516}=194.8, \mathrm{P}<0.0001\right.$; Figure 4a), $\mathrm{C}: \mathrm{P}\left(\mathrm{F}_{7,1516}=168.9, \mathrm{P}\right.$ $<0.0001$; Figure $4 \mathrm{~b})$, and N:P $\left(\mathrm{F}_{7,1516}=49.6, \mathrm{P}<0.0001\right.$; Figure $\left.4 \mathrm{c}\right)$ varied across species. $\mathrm{C}: \mathrm{N}$ and $\mathrm{C}: \mathrm{P}$ ratios were highest in A. antarctica, followed by Posidonia species. Mean $\mathrm{N}: \mathrm{P}$ ratios for all seagrass sampled were around 30 , indicating that neither $\mathrm{N}$ nor $\mathrm{P}$ is limiting (Atkinson and Smith 1983, Duarte 1990). However, N:P at individual sites could vary markedly, from clearly N-limited lows of 12.2 for A. antarctica and 12.8 for Posidonia sp. to clearly P-limited highs of 66.5 and 63.5, respectively. The highest ratios were in Cymodocea angustata and Halodule uninervis, and suggested that they were growing in P-limited conditions while Halophila spinulosa and Halophila ovalis exhibited the lowest $\mathrm{N}: \mathrm{P}$ ratios which were indicative of N-limitation.

One the basis of paired comparisons at sites where species co-occurred, the epiphytes collected from seagrasses always had lower P content than the seagrasses on which they were growing (Table 2a). Amphibolis antarctica had lower P content than all other seagrass taxa when growing with those other taxa. Posidonia sp. had lower P content than Halodule uninervis, Halophila ovalis, Cymodocea angustata and Syringodium isoetifolium, but there was no difference in the P content of Posidonia sp. and Halophila spinulosa. Halodule uninervis had lower $\mathrm{P}$ content than $H$. ovalis, but higher P content than H. spinulosa. Halophila ovalis had higher P content than its congener H. spinulosa, but lower P content than C. angustata. 
Similar to the P content, the $\mathrm{N}$ content of epiphytes was lower than any of the seagrasses on which they grew (Table 2b). Amphibolis antarctica had lower N content than any of the other seagrass taxa. Posidonia sp. had lower N content than Halodule uninervis, Halophila ovalis and Cymodocea angustata. Halodule uninervis had higher $\mathrm{N}$ content than H. ovalis, Halophila spinulosa and Syringodium isoetifolium, but lower than Cymodocea angustata. Halophila ovalis had higher $\mathrm{N}$ content than its congener $H$. spinulosa, but lower $\mathrm{N}$ content than C. angustata. Halophila spinulosa had lower $\mathrm{N}$ content than either C. angustata or S. isoetifolium, but C. angustata had higher N content than S. isoetifolium.

Like P and N content, the N:P ratio of epiphytes was lower than most of the seagrasses on which it grew. Halophila spinulosa N:P, however, did not differ significantly from its epiphytes and Halophila ovalis had a lower N:P ratio than its epiphytes (Table 2c). Amphibolis antarctica had a higher N:P ratio than H. ovalis, and $H$. spinulosa but lower than Posidonia sp., and Cymodocea angustata. Posidonia sp. had a higher N:P ratio than H. ovalis, H. spinulosa, and Syringodium isoetifolium. Halodule uninervis had a higher N:P ratio than H. ovalis, H. spinulosa, and S. isoetifolium but a lower N:P ratio than C. angustata. Halophila ovalis had a lower N:P ratio than $H$. spinulosa, and C. angustata. Halophila spinulosa had a higher N:P ratio than $S$. isoetifolium.

Nitrogen : Phosphorus ratios varied with distance from oceanic waters, sample region, and water depth as well as the interaction between distance and region (i.e., the effect of distance from the ocean varied among regions), but there was variation among species in how these factors influenced N:P ratios (Table 3). Amphibolis antarctica, 
Halodule uninervis and epiphyte N:P ratios varied with distance from the Indian Ocean, but the nature of this relationship varied across regions (Figure 5). In general, within each region N:P ratios increased with increasing distance from the ocean, but values for the Eastern Gulf were generally lower at further distances from the ocean and the slope of the relationship varied among regions. The Northern region had higher N:P than the Eastern and Western Gulfs for Cymodocea angustata, Halophila ovalis, and Syringodium isoetifolium (Table 3, Figure 6). For both Halophila species, N:P increased with increasing distance from the ocean, but the nature of this relationship did not vary among regions (Table 3, Figure 6). For epiphytes, Syringodium and Posidonia spp. there was a significant negative relationship between N:P and depth (Table 3).

Normalizing N:P ratios to that of $A$. antarctica allowed us to investigate spatial patterns of nutrient limitation across Shark Bay (Figure 7). The average deviation of my kriged surface of normalized N:P from the observed values at a location was 2.8 (RMSE). In general, N:P >> 30, indicating strong P-limitation, was limited to the Eastern Gulf, south of the Faure Sill. There are regions of $30>\mathrm{N}: \mathrm{P}>50$, indicating moderate $\mathrm{P}-$ limitation, in the southern area of the Western Gulf, along the mainland coast, and along the northeast coast of Peron Peninsula. The central portions of the bay had N:P ratios near 30, suggesting that these areas are not nutrient-limited. The waters along Dirk Hartog Island and the Northern Region have low N:P ratios, that are suggestive of Nlimitation, however due to sampling logistics, sample sites are limited in the center of the mouths of the Eastern and Western Gulfs. 


\section{Discussion}

Spatial patterns in the stoichiometry of seagrasses from Shark Bay indicate broad areas of the bay that appear to be N-limited and P-limited, and areas that are not nutrient limited despite the asserted general P-limitation of the system derived from budget calculations for the Eastern Gulf of the bay (Smith and Atkinson 1983, 1984). I do not see my results as contradictory to the conclusions drawn by Smith and Atkinson (1983, 1984). The work of Smith and Atkinson $(1983,1984)$ on system-scale budgets, suggested the mechanism driving $\mathrm{P}$ limitation is the stripping of $\mathrm{P}$ out of relatively $\mathrm{P}$ replete Indian Ocean source water as that water is advected into the system to replace water lost as a result of evaporation from the surface of the bay in this arid ecosystem. It stands to reason, then, that regions of the bay close to the P-replete source water receive ample P supply, while those distant from that source experience increased P limitation stress - precisely the pattern my stoichiometric map revealed. I suggest that within a system that as a whole appears limited by one resource there can exist broad areas where biomass and primary production can be limited by another resource. I found that strong evidence for P-limitation was restricted to the southern ends of both the Eastern and Western Gulfs (Figure 7). These areas are most distant from the oceanic P source that fuels net production and have long water residence times (Smith and Atkinson 1983, Atkinson 1987, Price et al. in press). Thus, my results support for the contention that water residence time is a main driver of the relative importance of $\mathrm{N}$ and $\mathrm{P}$ in limiting biomass and net production in aquatic systems (Smith and Atkinson 1984, Smith 1984). Areas within Shark Bay less isolated from the oceanic P source were N-limited and areas in the middle reaches of the system were neither N- nor P-limited. 
Phosphorus in the system is delivered by tidal water exchange with the relatively phosphorus-rich waters of the Indian Ocean. Indeed, seagrasses showed moderate Plimitation near the primary freshwater input to the Bay despite upstream agriculture. Therefore, distance from the mouth of the bay serves as a reasonable proxy for phosphorus availability throughout the system, although the strength of the distance effect varied somewhat across the three broad regions of the bay. In the Western Gulf, Plimitation appeared to occur at closer distances to the ocean than in the Eastern Gulf or Northern Region. Overall, the gradient of phosphorus limitation, with the highest levels occurring in the most isolated areas, is very similar to findings in Florida Bay, USA (Fourqurean and Zieman 2002, Fourqurean et al. 2005). However, some species showing Redfield-like N:P from deep sites suggest that some areas of the bay are not nutrient limited and other factors (e.g., light limitation, depth limitation, herbivore limitation, etc.) also play an important role in ecosystem dynamics in this system. Combined with the bioassay work on nutrient limitation of the phytoplankton communities (Segal et al. 2009), my results also suggest that spatial patterns of N- and P-limitation with distance from the mouth may operate differently for benthic and pelagic portions of the water column. Segal et al. (2009) found that within Useless Loop (Western Gulf), phytoplankton were N-limited near the open bay and P-limited deeper into the embayment. In contrast, although I found evidence for moderate N-limitation of the benthos near the open bay, the remainder of the benthic system in Useless Loop/Central Western Gulf appears to not be nutrient-limited.

The finding of elevated N:P in the most isolated parts of Shark Bay, with low N:P further offshore mirrors the patterns in stoichiometry of the seagrasses of south Florida 
(Fourqurean and Zieman 2002, Fourqurean et al. 2005) as well as the onshore-offshore pattern observed in Sulawesi, Indonesia (Erftmeier 1994) and in the mangrove-lined creeks of the Bahamas (Allgeier et al. 2011). The inferences about resource limitation derived from these stoichiometric spatial patterns - N-limitation offshore, P-limitation in more isolated bays - have been verified with nutrient addition experiments in south Florida (Ferdie and Fourqurean 2004, Armitage et al. 2011). My findings examine the utility of using stoichiometry of long-lived, sessile benthic primary producers for generating hypotheses about the functioning of ecosystems. Nutrient addition assays have not yet been conducted in Shark Bay to test these hypotheses. It is interesting to note, however, that in general the N:P ratios of Shark Bay seagrasses are lower than those from the severely P-limited regions of Florida Bay, which are often in excess of 96, suggesting that the scarcity of P in Shark Bay is not as severe as in Florida Bay. It is not just in carbonate-dominated, tropical locations that the spatial pattern in stoichiometry of seagrasses has been shown to be an indicator of relative nutrient availability across an ecosystem. For example, $\mathrm{N}$ content of the temperate seagrass Zostera marina decreases with increasing N-limitation in Tomales Bay, California (Fourqurean et al. 1997) and variation in $\mathrm{C}: \mathrm{N}: \mathrm{P}$ in the seagrasses and epiphytes of the northern Gulf of Mexico indicates distinct regions of $\mathrm{N}$ - and P-limitation (Johnson et al. 2006).

The spatial patterns in the relative importance of $\mathrm{N}$ and $\mathrm{P}$ in Shark Bay suggest that changes in $\mathrm{N}$ and P delivery to Shark Bay would have different consequences depending on the location within the bay. In the southern reaches of both the Eastern and Western Gulfs, $\mathrm{P}$ addition would likely cause increases in benthic primary production and change the community structure of the benthic primary producers and consumers, while 
$\mathrm{N}$ addition would likely have few effects. However, $\mathrm{N}$ inputs in the southern reaches of the system could potentially be transported towards the ocean and affect the seagrass communities of the less isolated, $\mathrm{N}$-limited parts of the system. If management decisions about changes in nutrient delivery to a system were made on the basis of the wholesystem nutrient budgets as done for Shark Bay (Smith and Atkinson 1984), such far-field effects could not be anticipated, suggesting the need for understanding of the resource availability landscape.

Spatial variation in the importance of $\mathrm{P}$ as a limiting nutrient in Shark Bay occurred despite the distribution of carbonate sediments across the entire bay. Owing to the high phosphate binding capacity of carbonate sediment and the resultant low mobility of P in carbonate systems (de Kanel and Morse 1978) and the common observations of P limitation of benthic primary production in carbonate sediment ecosystems (e.g., Short et al. 1985, Fourqurean et al. 1992), a paradigm of the general P-limitation of primary production in carbonate sediment ecosystems arose. However, not all carbonate ecosystems are P-limited, and in fact adjacent $\mathrm{N}$ - and P-limited regions in carbonate sediment ecosystems have now been identified in Shark Bay (Figure 7) and south Florida (Fourqurean and Zieman 2002), which suggests that the carbonate content of sediments does not alone determine whether $\mathrm{N}$ or $\mathrm{P}$ will limit benthic primary production. While phosphate does strongly bind to carbonate sediments (de Kanel and Morse 1987), respiration that generates acidity dissolves carbonate sediments (Jensen et al. 1998, Burdige et al. 2008), releasing the bound phosphorus (Jensen et al. 2009). Further, organic acids produced by seagrasses can also dissolve carbonates and release phosphorus (Long et al. 2008). Clearly, factors like N:P of loadings and rates of nitrogen 
fixation and denitrification interact with sediment type to determine whether $\mathrm{N}$ or $\mathrm{P}$ are limiting factors in carbonate sediments.

Prior to this study, limited data on the N and P content of seagrasses from Shark Bay have been reported. The seasonally-averaged N:P of $P$. australis was reported as 25 and A. antarctica as 32 in a study of growth and nutrient content of these species near Monkey Mia, midway up the Eastern Gulf of Shark Bay (ratios calculated from data in Walker et al. 1988); my data from this same area indicates N:P in the same range. These values suggest balanced N and P availability (Atkinson and Smith 1983, Duarte 1990); I interpret this to indicate that nutrients are not the limiting factor of biomass and primary production in the dense meadows characteristic of this area. I document a great range in the N:P for these two taxa across the ecosystem, however, from 12.2-66.5 for $A$. antarctica and 12.8-63.0 for Posidonia sp. (Figure 4), suggesting the relative availability of $\mathrm{N}$ and $\mathrm{P}$ for these species varies greatly across the system. Published data on the elemental content of other taxa from Shark Bay are lacking.

Elemental content of organisms is of course taxon-specific, as differences in architecture of organisms requires differing relative amounts of the various biomolecules needed to build and maintain morphologically and metabolically diverse organisms (Sterner and Elser 2002). It is now becoming clear that morphologically similar organisms - like the seagrasses, for example - have distinct elemental ratios even when they are growing intermixed with other seagrasses. In south Florida in the subtropical Atlantic, which in general has seagrass N:P values suggestive of nutrient limitation across the landscape, slower growing species generally showed less nutrient-limited N:P than fast growing species from the same locations, even though fast-growing species had 
higher $\mathrm{N}$ and $\mathrm{P}$ content than the slow-growing species (Campbell and Fourqurean 2009). In Shark Bay, I also found that the taxa with the faster relative growth rates had higher average $\mathrm{N}$ and $\mathrm{P}$ contents than the slower growing taxa. The slow-growing seagrasses Amphibolis antarctica and Posidonia sp. have biomass turnover rates of 3.8 to $3.9 \mathrm{y}^{-1}$, compared to the smaller, faster-growing taxa like Cymodocea spp. (11.7-12.0 $\left.\mathrm{y}^{-1}\right)$, Syringodium spp. (11.0-13.7 $\left.\mathrm{y}^{-1}\right)$, Halodule spp. $\left(13.9 \mathrm{y}^{-1}\right)$ and Halophila spp. (17.2-32.4 $\left.\mathrm{y}^{-1}\right)$ (Duarte 1991). Averaged across all collections, the slow-growing taxa had lower $\mathrm{N}$ and $\mathrm{P}$ content, as indicated by higher $\mathrm{C}: \mathrm{N}$ and $\mathrm{C}: \mathrm{P}$, than the faster-growing taxa (Figure 4a,b). Within sites where species co-occurred, there were consistent differences between species pairs (Table 2), allowing us to calculate a standardized seagrass elemental content across sites with different species composition. Such standardization allowed us to make ecosystem-scale inferences that would not have been possible otherwise because of the taxon-specific distributions and elemental contents.

I also found that seagrass species varied considerably in their nutrient content, and possibly palatability, to herbivores. Nutrient content is one of many key drivers of herbivore forage selection (e.g., Bjorndal 1980, Boyer et al. 2004, Armitage and Fourqurean 2006), and appears to play a role in forage choice of herbivores in Shark Bay (Burkholder et al. in press). Further investigation is needed, however, to fully elucidate herbivore forage choice in this system. Species-specific differences in nutrient content can lead to species-specific herbivory. Because seagrass species in Shark Bay with lower nutrient content (especially Amphibolis antarctica) provide shelter for some herbivores 
(e.g., P. octolineatus ${ }^{1}$; Heithaus 2004), these low-quality forage species (Burkholder et al. in press) may enhance herbivory rates on more palatable species. In conclusion, by normalizing N:P ratios across seagrass species I was able to elucidate spatial patterns of nutrient-limitation in an iconic P-limited coastal ecosystem. I found that P-limitation occurred, despite calcium carbonate sediments, only in the most isolated portions of the bay and large areas were either N-limited or not nutrient limited, where I believe light limitation is the most likely driver. Therefore, management decisions aimed at avoiding eutrophication should consider potential meso-scale variation in nutrient limitation within coastal ecosystems. The low rainfall, low runoff nature of Shark Bay and the very low human population densities in its watershed suggest that large-scale eutrophication from terrestrial anthropogenic sources of this system is not likely in the near future, but nonetheless, the broad parts of the system that are nutrient-limited are at risk to eutrophication if the human population grows markedly in this area.

\section{Acknowledgements}

I would like to thank the Monkey Mia Dolphin Resort for providing lodging and logistical support throughout the study. Special thanks to Department of Environment and Conservation for logistical field support and an army of field assistants that made the project possible. Kirk Gastrich and the Seagrass Ecosystems Research Lab provided invaluable assistance in the lab. Funding for this project was provided by National Science Foundation grants OCE0526065 and OCE0745606, a Supplement to the Florida

\footnotetext{
${ }^{1} P$. octolineatus has previously been refered to as $P$. sexlineatus in the literature. P. octolineatus, a western Australian species, is now considered distinct from $P$. sexlineatus which is now considered to be confined to eastern Australia.
} 
Coastal Everglades Long Term Ecological Research Project grant DBI0620409, and an FIU Dissertation Evidence Acquisition Fellowship to D. Burkholder. I thank Jopalo Boats, Bombadier Recreation Products, Humminbird, The Airline, and Submersible Systems for significant donations in the form of discounts on boats and equipment. Research was conducted under DEC permit numbers: CE001685, CE002300, CE001879, SW01147, SW012509, SW11794 and subsequent annual renewals. This is contribution \#x of the Shark Bay Ecosystem Research Project and \#x of the Southeast Environmental Research Center at Florida International University. 
Table 1. Bottom cover of seagrasses at 475 sites in Shark Bay, Western Australia.

Values are based on averages of three subplots per site. Med. $=$ Median, $\mathrm{FO}=$ Frequency of Occurrence

\begin{tabular}{lllllll}
\hline \hline & \multicolumn{2}{c}{ All sites } & \multicolumn{3}{c}{ When present } \\
Species & Mean $\pm \mathrm{sd}$ & Med. & FO & Mean $\pm \mathrm{sd}$ & Med. & Max. \\
\hline A. antarctica & $44.25 \pm 43.63$ & 35 & 58.9 & $74.53 \pm 30.74$ & 90 & 100 \\
C. angustata & $0.55 \pm 4.21$ & 0 & 9.1 & $5.80 \pm 12.66$ & 2.5 & 80 \\
Halophila ovalis & $0.15 \pm 1.16$ & 0 & 5.1 & $2.70 \pm 4.31$ & 1.1 & 15.8 \\
Halodule uninervis & $1.21 \pm 4.32$ & 0 & 25.7 & $4.62 \pm 7.49$ & 1.6 & 48.35 \\
Halophila spinulosa & $0.61 \pm 4.08$ & 0 & 8.0 & $7.19 \pm 12.39$ & 1.7 & 65 \\
Posidonia spp & $7.65 \pm 20.74$ & 0 & 22.1 & $33.98 \pm 31.93$ & 26.6 & 100 \\
S. isoetifolium & $0.09 \pm 0.63$ & 0 & 3.4 & $2.34 \pm 2.35$ & 1.6 & 9 \\
\hline
\end{tabular}


Table 2a. Differences in phosphorus concentration (\%P) among co-occurring seagrass species and epiphytes. Numbers above the diagonal represent the difference in phosphorus content of the species in the first column minus the species across the top (e.g. $\% \mathrm{P}$ of $\mathrm{Aa}-\% \mathrm{P}$ of $\mathrm{Psp}=-0.006$ ). Numbers below the diagonal are sample sizes. Aa $=$ Amphibolis antarctica, $\mathrm{Ca}=$ Cymodocea angustata, $\mathrm{Epi}=$ epiphytes, $\mathrm{Ho}=$ Halophila ovalis, $\mathrm{Hs}=$ Halophila spinulos $\mathrm{Hu}=$ Halodule uninervis. $\mathrm{Psp}=$ Posidonia $\mathrm{sp}$ (primarily P. australis), $\mathrm{Si}=$ Syringodium isoetifolium. $* \mathrm{P} \leq 0.05,{ }^{* *} \mathrm{P} \leq 0.01, * * * \mathrm{P} \leq$ $0.001, \mathrm{NS}=$ not significant $(\mathrm{P}>0.05)$.

\begin{tabular}{|c|c|c|c|c|c|c|c|c|}
\hline & Aa & Psp & Hu & Ho & Hs & Ca & Si & Epi \\
\hline Aa & - & $-0.006^{*}$ & $-0.036^{* * *}$ & $-0.115^{* * *}$ & $-0.034^{* * *}$ & $-0.035^{* * *}$ & $-0.039^{* * *}$ & $0.013^{* * *}$ \\
\hline Psp & 77 & - & $-0.032^{* * *}$ & $-0.011^{* *}$ & NS & $-0.036^{* * *}$ & $-0.032^{*}$ & $0.008^{* * *}$ \\
\hline Hu & 78 & 53 & - & $-0.098^{* * *}$ & $0.027^{* *}$ & NS & NS & $0.042^{* * *}$ \\
\hline Ho & 17 & 16 & 22 & - & $0.145^{* * *}$ & $-0.137^{* * *}$ & NS & $0.139^{* * *}$ \\
\hline Hs & 18 & 6 & 15 & 11 & - & NS & NS & $0.040^{* * *}$ \\
\hline Ca & 32 & 24 & 30 & 11 & 6 & - & NS & $0.045^{* * *}$ \\
\hline Si & 20 & 12 & 16 & 6 & 4 & 12 & - & $0.040^{* * *}$ \\
\hline Epi & 265 & 109 & 92 & 27 & 26 & 41 & 21 & - \\
\hline
\end{tabular}


Table 2b. Differences in nitrogen concentration $(\% \mathrm{~N})$ among co-occurring seagrass species and epiphytes (above the diagonal). Numbers above the diagonal represent the difference in nitrogen content of the species in the first column minus the species across the top (e.g. $\% \mathrm{~N}$ of $\mathrm{Aa}-\% \mathrm{~N}$ of Psp $=-0.273$ ). Numbers below the diagonal are sample sizes

\begin{tabular}{|c|c|c|c|c|c|c|c|c|}
\hline & Aa & Psp & Hu & Ho & Hs & Ca & Si & Epi \\
\hline Aa & - & $-0.273^{* * *}$ & $-0.565^{* * *}$ & $-0.446^{* * *}$ & NS & $-0.761^{* * *}$ & $-0.518^{* * *}$ & $0.296^{* * *}$ \\
\hline Psp & 77 & - & $-0.391^{* * *}$ & $-0.436^{* * *}$ & NS & $-0.665^{* * *}$ & NS & $0.421^{* * *}$ \\
\hline Hu & 76 & 53 & - & $0.142^{*}$ & $0.710^{* * *}$ & $-0.215^{* *}$ & $0.174^{*}$ & $0.822^{* * *}$ \\
\hline Ho & 17 & 16 & 22 & - & $0.543^{* * *}$ & $-0.269^{* * *}$ & NS & $0.729^{* * *}$ \\
\hline Hs & 18 & 6 & 15 & 11 & - & $-0.828^{* * *}$ & $-0.377^{*}$ & $0.421^{* * *}$ \\
\hline Ca & 32 & 24 & 31 & 11 & 6 & - & $0.331^{* *}$ & $1.143^{* * *}$ \\
\hline Si & 20 & 12 & 16 & 6 & 4 & 12 & - & $0.747^{* * *}$ \\
\hline Epi & 265 & 108 & 90 & 27 & 26 & 41 & 21 & - \\
\hline
\end{tabular}


Table 2c. Differences in N:P among co-occurring seagrass species and epiphytes (above the diagonal). Numbers above the diagonal represent the difference in $\mathrm{N}: \mathrm{P}$ of leaf tissues of the species in the first column minus the species across the top (e.g. N:P of Aa $-\mathrm{N}: \mathrm{P}$ of Psp $=-4.6)$. Numbers below the diagonal are sample sizes.

\begin{tabular}{|l|c|c|c|c|c|c|c|c|}
\hline & Aa & Psp & Hu & Ho & Hs & Ca & Si & Epi \\
\hline Aa & - & $-4.6^{* * *}$ & NS & $8.5^{* *}$ & $7.9^{* * *}$ & $-5.6^{*}$ & NS & $2.4^{* * *}$ \\
\hline Psp & 77 & - & NS & $8.1^{*}$ & $11.9^{*}$ & NS & $7.3^{*}$ & $8.2^{* * *}$ \\
\hline Hu & 76 & 53 & - & $13.1^{* * *}$ & $6.3^{* *}$ & $-4.7^{*}$ & $5.6^{*}$ & $4.6^{* * *}$ \\
\hline Ho & 17 & 16 & 22 & - & $-8.8^{* *}$ & $-20.0^{* * *}$ & NS & $-5.3^{*}$ \\
\hline Hs & 18 & 6 & 15 & 11 & - & $-11.3^{* *}$ & NS & NS \\
\hline Ca & 32 & 24 & 31 & 11 & 6 & - & $9.1^{* *}$ & $12.5^{* * *}$ \\
\hline Si & 20 & 12 & 16 & 6 & 4 & 12 & - & $7.0^{* *}$ \\
\hline Epi & 261 & 108 & 90 & 27 & 26 & 41 & 21 & - \\
\hline
\end{tabular}

Cymodocea higher than everything in NP 
Table 3. Effects of region, distance to the Indian Ocean, depth, and the interaction of region and distance on $\mathrm{N}: \mathrm{P}$. Non-significant interactions $(\mathrm{P}>0.10)$ were removed from final models.

\begin{tabular}{|l|l|l|l|l|l|l|l|l|}
\hline & \multicolumn{2}{l}{ Region } & \multicolumn{2}{l}{ Distance to Ocean } & \multicolumn{2}{l}{ Depth } & \multicolumn{2}{l|}{ Region x Distance } \\
\hline & F & P & F & P & F & P & F & P \\
\hline Aa*** & $\mathbf{4 1 . 9}$ & $\mathbf{0 . 0 0 0 1}$ & $\mathbf{6 1 . 1}$ & $\mathbf{0 . 0 0 0 1}$ & 1.9 & 0.17 & $\mathbf{3 . 1}$ & $\mathbf{0 . 0 5}$ \\
\hline Psp* & 1.3 & 0.27 & 3.7 & 0.06 & $\mathbf{6 . 2}$ & $\mathbf{0 . 0 1}$ & NS & NS \\
\hline Hu$^{* * *}$ & $\mathbf{1 0 . 4}$ & $\mathbf{0 . 0 0 0 1}$ & $\mathbf{3 3 . 9}$ & $\mathbf{0 . 0 0 0 1}$ & 0.0 & 0.95 & $\mathbf{1 0 . 4}$ & $\mathbf{0 . 0 0 0 1}$ \\
\hline Hs** $^{*}$ & $\mathbf{6 . 9}$ & $\mathbf{0 . 0 0 3}$ & $\mathbf{1 2 . 6}$ & $\mathbf{0 . 0 0 1}$ & 1.5 & 0.23 & NS & NS \\
\hline Ho*** & $\mathbf{1 8 . 0}$ & $\mathbf{0 . 0 0 0 1}$ & $\mathbf{1 8 . 8}$ & $\mathbf{0 . 0 0 0 2}$ & 0.3 & 0.57 & NS & NS \\
\hline Ca** & $\mathbf{8 . 2}$ & $\mathbf{0 . 0 0 1}$ & 0.1 & 0.93 & 0.6 & 0.46 & NS & NS \\
\hline Si* & $\mathbf{4 . 7}$ & $\mathbf{0 . 0 2}$ & 0.3 & 0.55 & $\mathbf{4 . 8}$ & $\mathbf{0 . 0 4}$ & NS & NS \\
\hline Epi*** & $\mathbf{5 9 . 9}$ & $\mathbf{0 . 0 0 0 1}$ & $\mathbf{9 4 . 9}$ & $\mathbf{0 . 0 0 0 1}$ & $\mathbf{5 . 4}$ & $\mathbf{0 . 0 2}$ & $\mathbf{1 6 . 5}$ & $\mathbf{0 . 0 0 0 1}$ \\
\hline
\end{tabular}

Final models: $A a: \mathrm{F}_{6,271}=40.3, \mathrm{P}<0.0001, \mathrm{R}^{2}=0.48 ; P$ sp: $\mathrm{F}_{4,113}=2.5, \mathrm{P}=0.04, \mathrm{R}^{2}=0.08$;

$H u: \mathrm{F}_{6,113}=30.6, \mathrm{P}<0.0001, \mathrm{R}^{2}=0.63 ; H_{s}: \mathrm{F}_{4,37}=4.7, \mathrm{P}=0.004, \mathrm{R}^{2}=0.36 ; H o: \mathrm{F}_{4,33}=16.3$, $\mathrm{P}<0.0001, \mathrm{R}^{2}=0.69 ; C a: \mathrm{F}_{4,42}=4.1, \mathrm{P}=0.008, \mathrm{R}^{2}=0.30 ; S i: \mathrm{F}_{6,21}=4.2, \mathrm{P}=0.02, \mathrm{R}^{2}=0.50 ;$ Epi: $\mathrm{F}_{6,315}=51.2, \mathrm{P}<0.0001, \mathrm{R}^{2}=0.50$ 


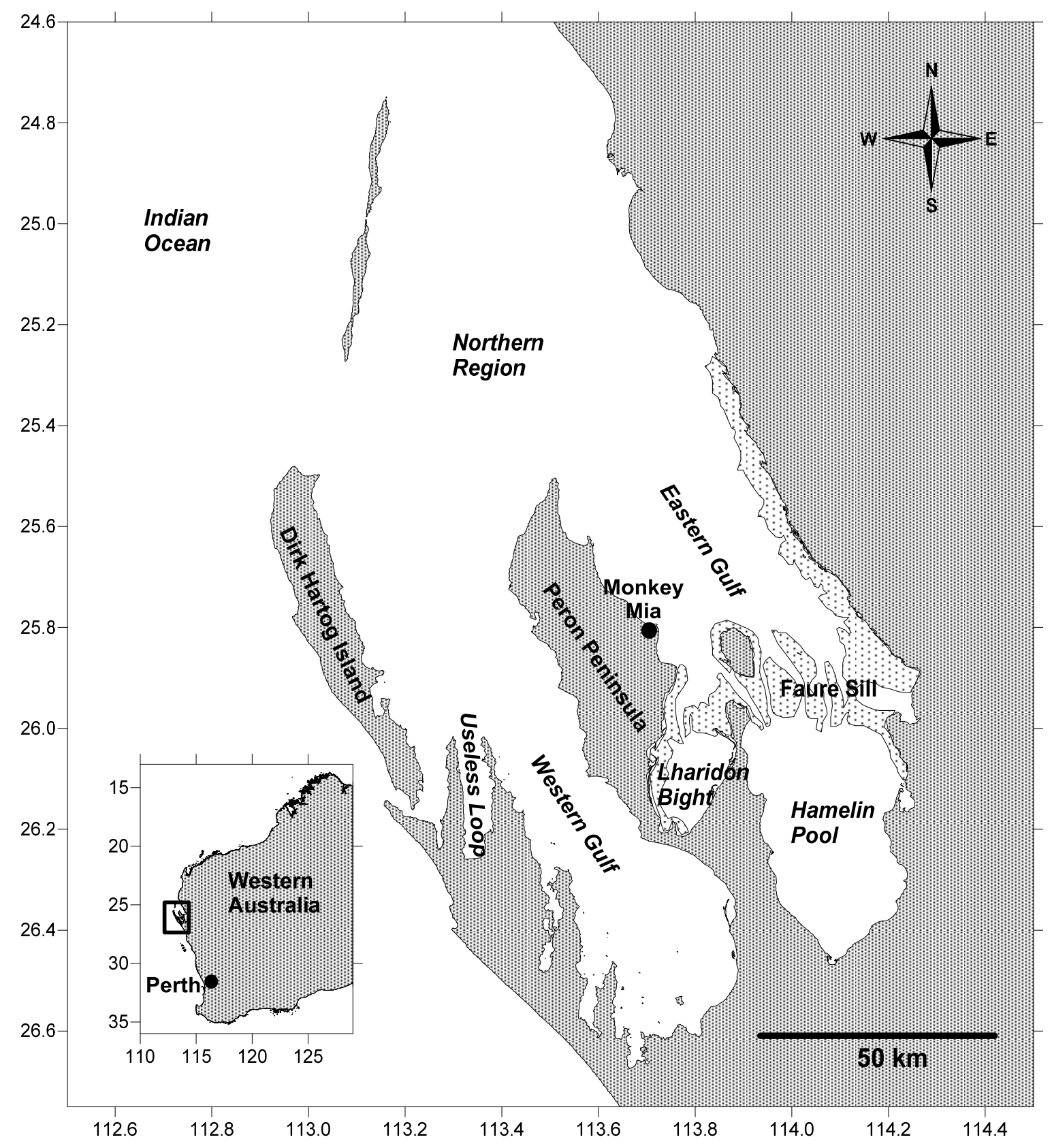

Figure 1: World and Bay map with Eastern Gulf, Western Gulf, and Northern regions outlined, and major landmarks. 
a) Taxa Richness

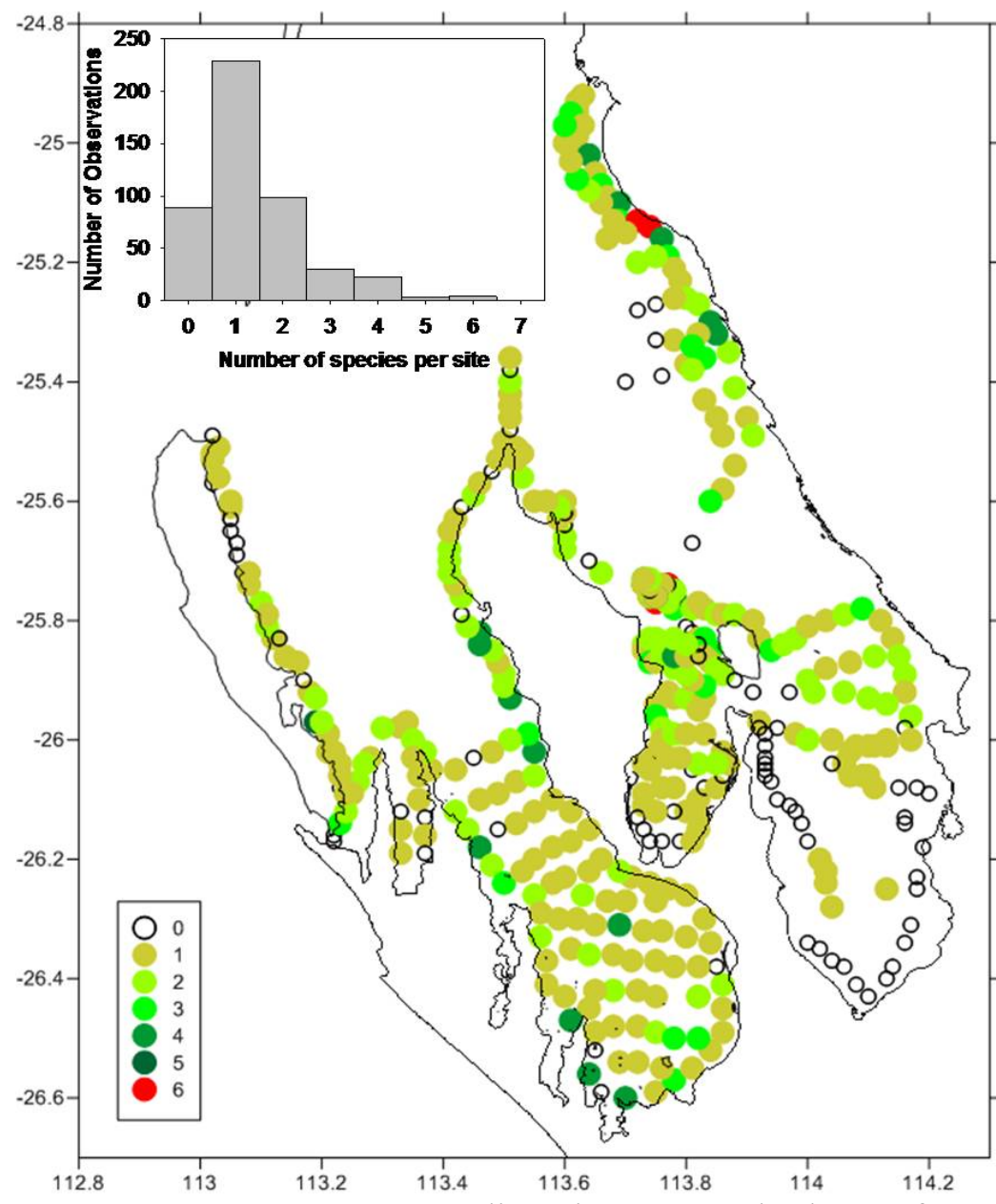

b) Amphibolis antarctica

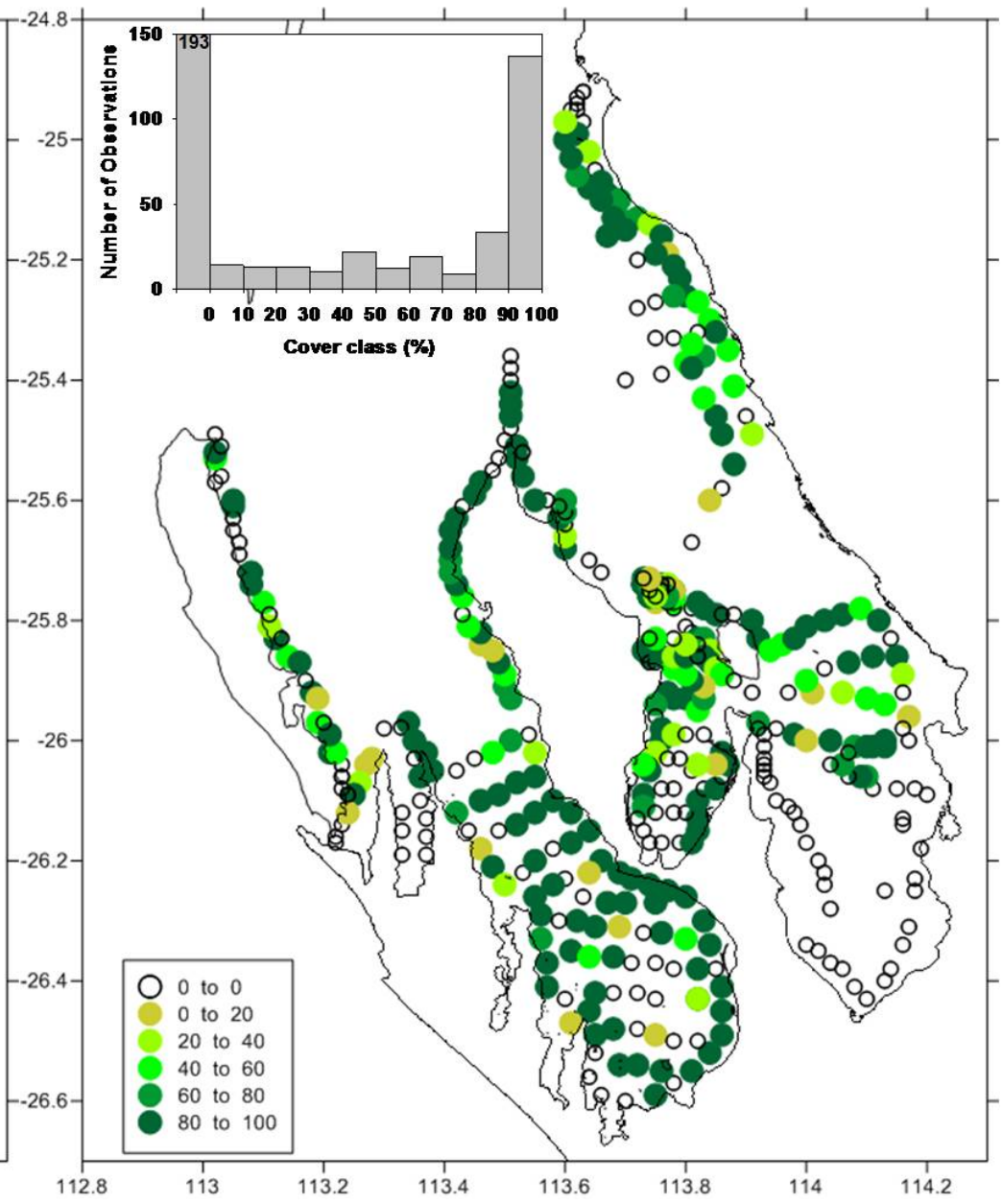

Figure 2: Seagrass taxa diversity across Shark Bay from both summer and winter sampling effort, (a) and average

abundances of seagrass species across Shark Bay (b) Amphibolis antarctica. Positions of the symbols indicate sampling locations. Insets show frequency histograms of species richness (a) or percent cover (b-h). 


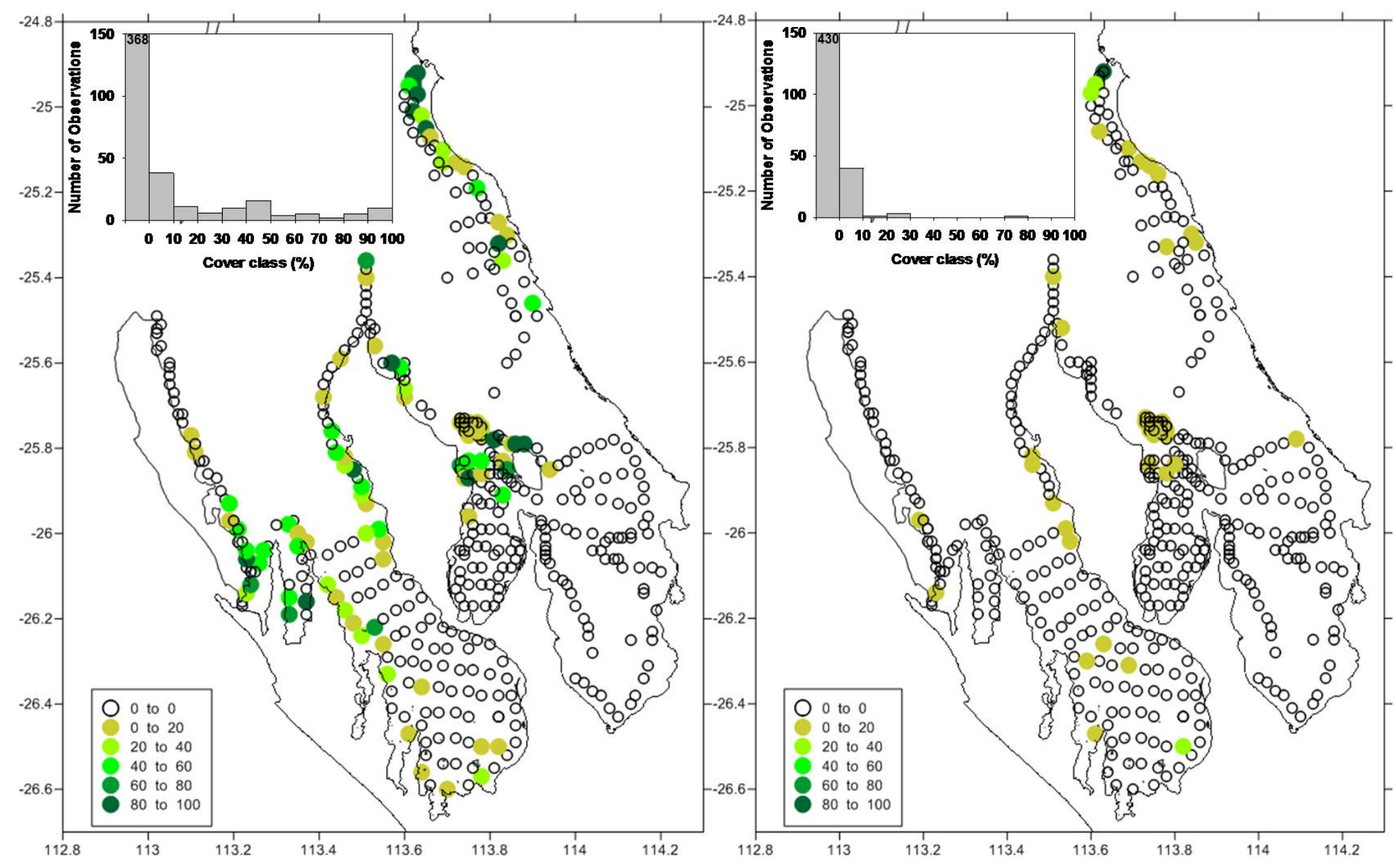

Figure 2: Average abundances of seagrass species across Shark Bay, (c) Posidonia spp. (d) Cymodocea angustata.

Positions of the symbols indicate sampling locations. Insets show frequency histograms of percent cover (b-h). 


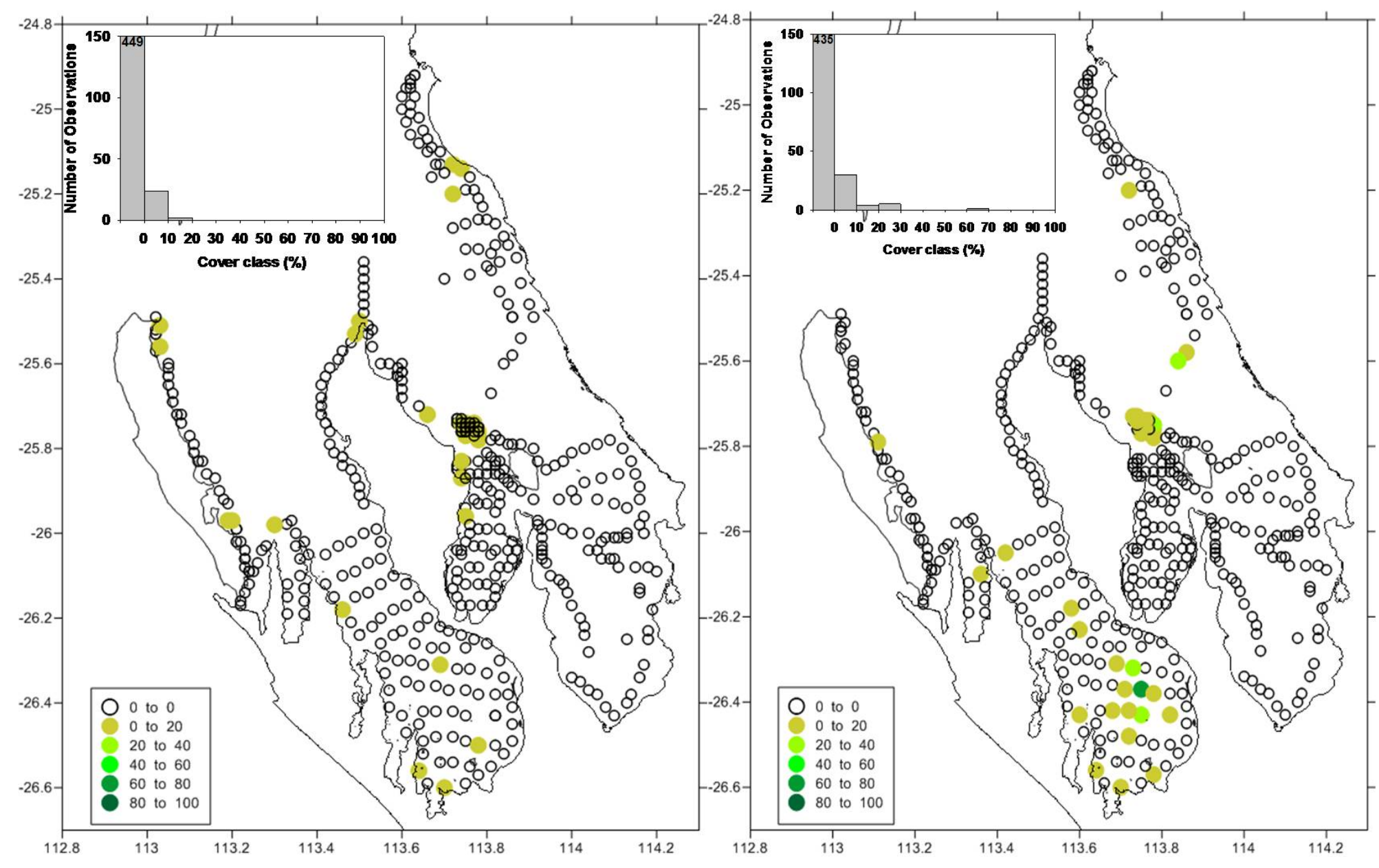

Figure 2: Average abundances of seagrass species across Shark Bay, (e) Halophila ovalis (f) Halophila spinulosa.

Positions of the symbols indicate sampling locations. Insets show frequency histograms of percent cover (b-h). 

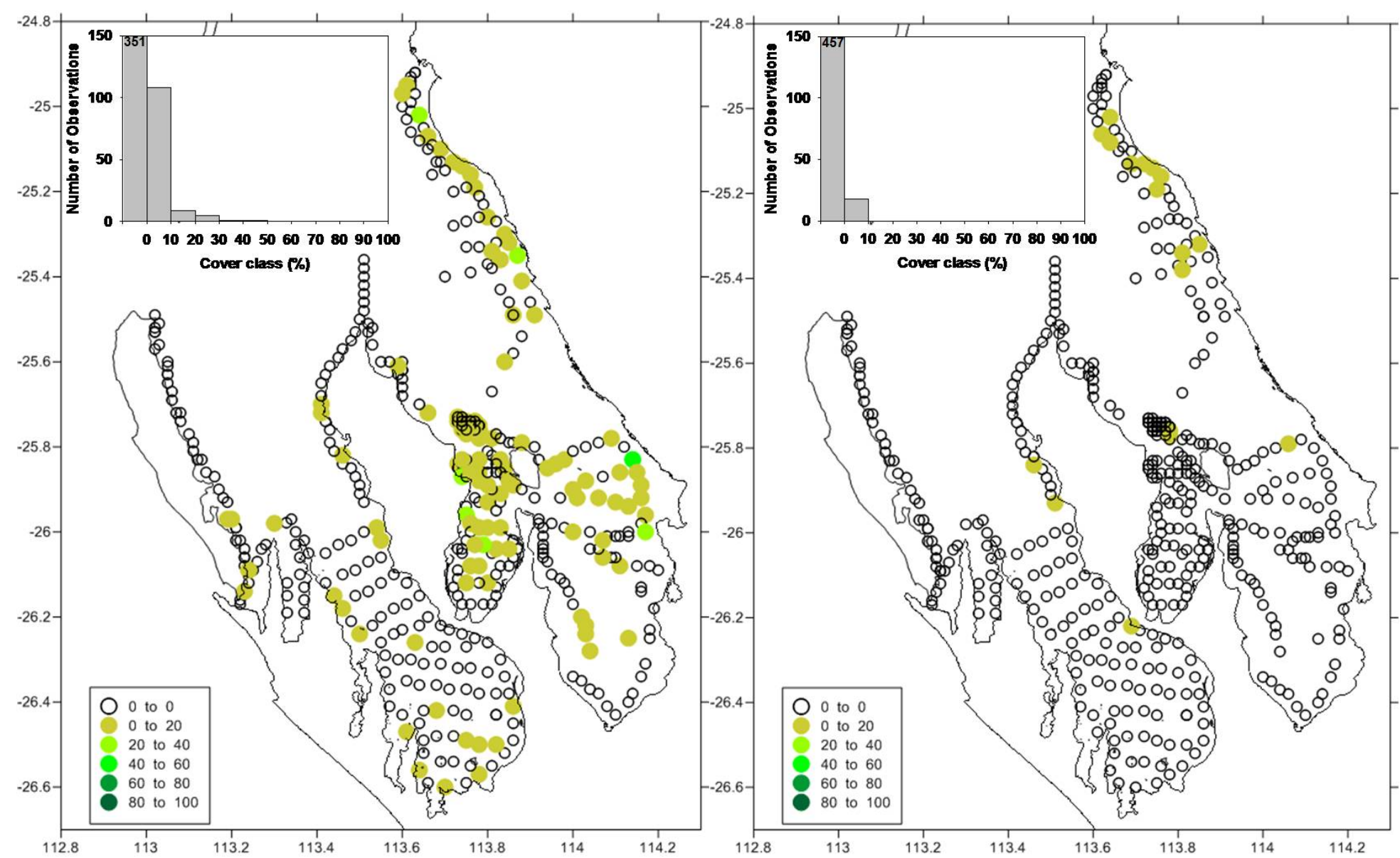

Figure 2: Average abundances of seagrass species across Shark Bay, (g) Halodule uninervis (h) Syringodium isoetifolium. Positions of the symbols indicate sampling locations. Insets show frequency histograms of percent cover (b-h). 


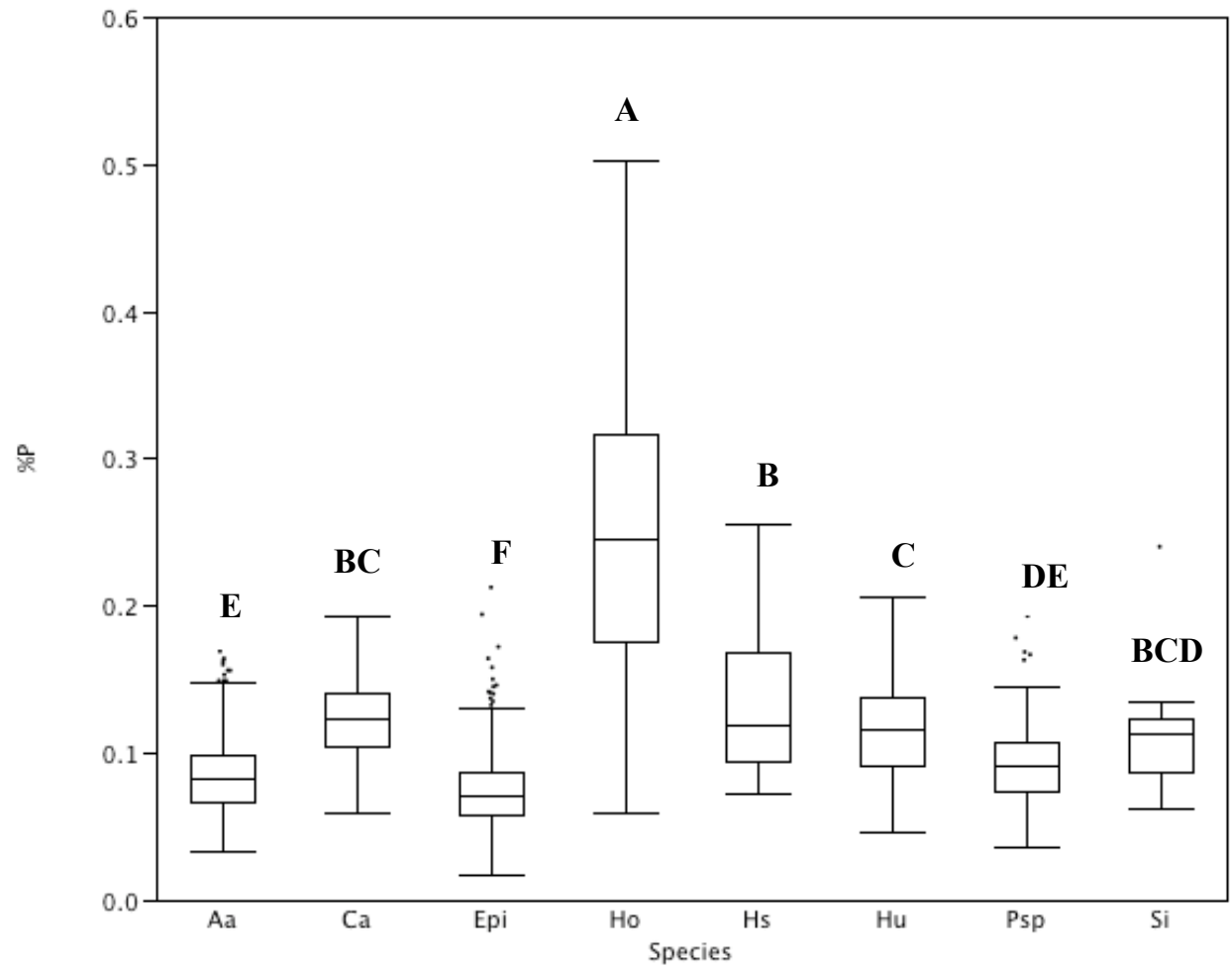

Figure 3a: Phosphorus content of seagrass and epiphytes in Shark Bay, Australia during warm season. Boxes with the same letter indicate no significant differences at $\mathrm{P}<0.05$ for Tukey's test. Sample sizes are provided above Panel $a . \mathrm{Aa}=$ Amphibolis antarctica, $\mathrm{Ca}=$ Cymodocea angustata, Epi $=$ epiphytes, $\mathrm{Ho}=$ Halophila ovalis, $\mathrm{Hs}=$ Halophila spinulosa $\mathrm{Hu}=$ Halodule uninervis. $\mathrm{Psp}=$ Posidonia $\mathrm{sp}$ (primarily P. australis), $\mathrm{Si}=$ Syringodium isoetifolium. 


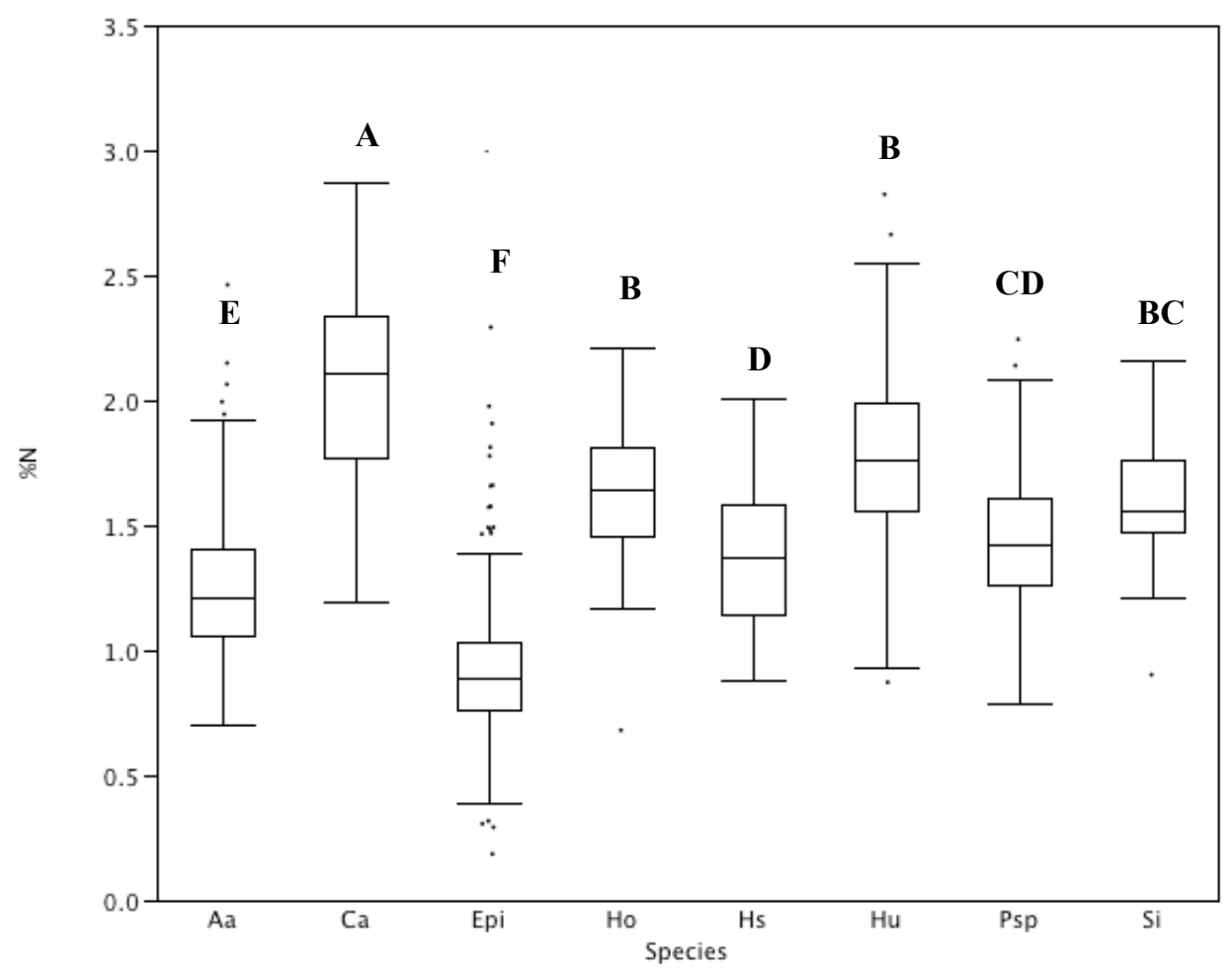

Figure 3b: Nitrogen content of seagrass and epiphytes in Shark Bay, Australia during warm season. Boxes with the same letter indicate no significant differences at $\mathrm{P}<0.05$ for Tukey's test. Sample sizes are provided above Panel $a$. Aa = Amphibolis antarctica, $\mathrm{Ca}=$ Cymodocea angustata, $\mathrm{Epi}=$ epiphytes, $\mathrm{Ho}=$ Halophila ovalis, $\mathrm{Hs}=$ Halophila spinulosa $\mathrm{Hu}=$ Halodule uninervis. $\mathrm{Psp}=$ Posidonia $\mathrm{sp}($ primarily P. australis), $\mathrm{Si}=$ Syringodium isoetifolium. 


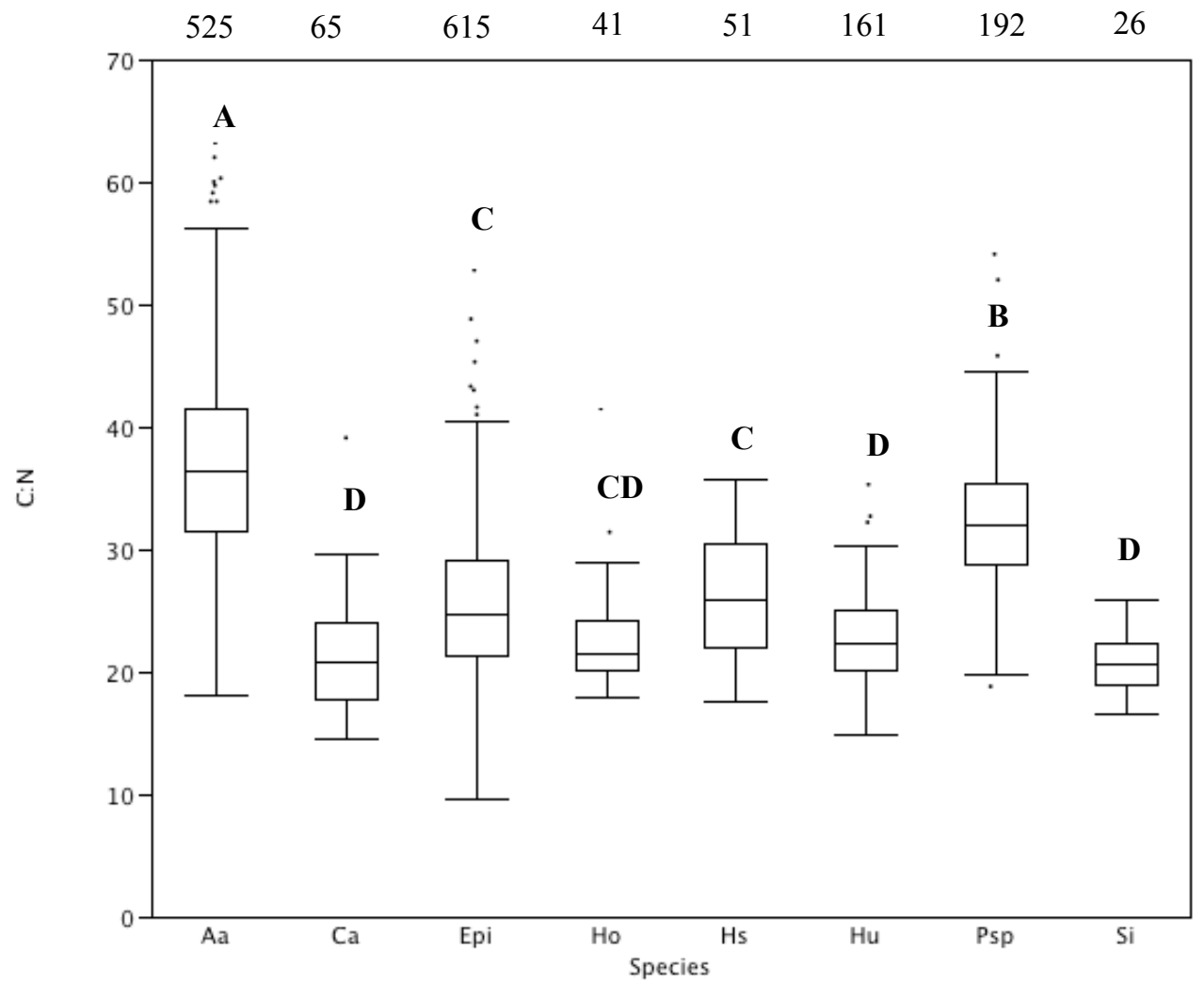

Figure 4a: Ratios of $\mathrm{C}: \mathrm{N}$ for seven species of seagrass and epiphytes in Shark Bay, Australia during warm season. Boxes with the same letter indicate no significant differences at $\mathrm{P}<0.05$ for Tukey's test. Sample sizes are provided above Panel $a$. Aa $=$ Amphibolis antarctica, $\mathrm{Ca}=$ Cymodocea angustata, $\mathrm{Epi}=$ epiphytes, $\mathrm{Ho}=$ Halophila ovalis, $\mathrm{Hs}=$ Halophila spinulosa $\mathrm{Hu}=$ Halodule uninervis. $\mathrm{Psp}=$ Posidonia $\mathrm{sp}$ (primarily $P$. australis), $\mathrm{Si}=$ Syringodium isoetifolium. 


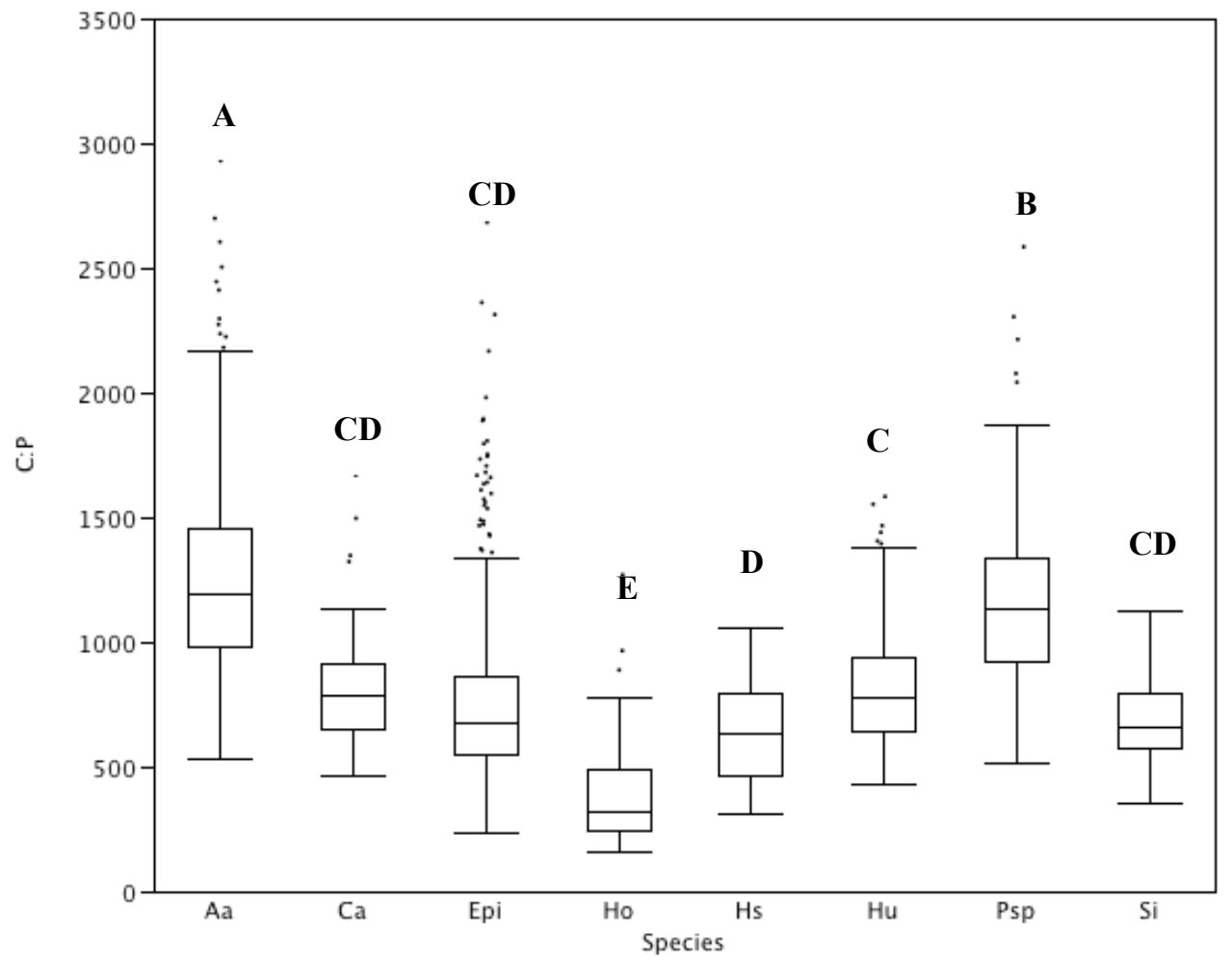

Figure 4b: Ratios of C:P for seven species of seagrass and epiphytes in Shark Bay, Australia during warm season. Boxes with the same letter indicate no significant differences at $\mathrm{P}<0.05$ for Tukey's test. Sample sizes are provided above Panel $a$. Aa $=$ Amphibolis antarctica, $\mathrm{Ca}=$ Cymodocea angustata, $\mathrm{Epi}=$ epiphytes, $\mathrm{Ho}=$ Halophila ovalis, $\mathrm{Hs}=$ Halophila spinulosa $\mathrm{Hu}=$ Halodule uninervis. $\mathrm{Psp}=$ Posidonia $\mathrm{sp}$ (primarily $P$. australis), $\mathrm{Si}=$ Syringodium isoetifolium. 


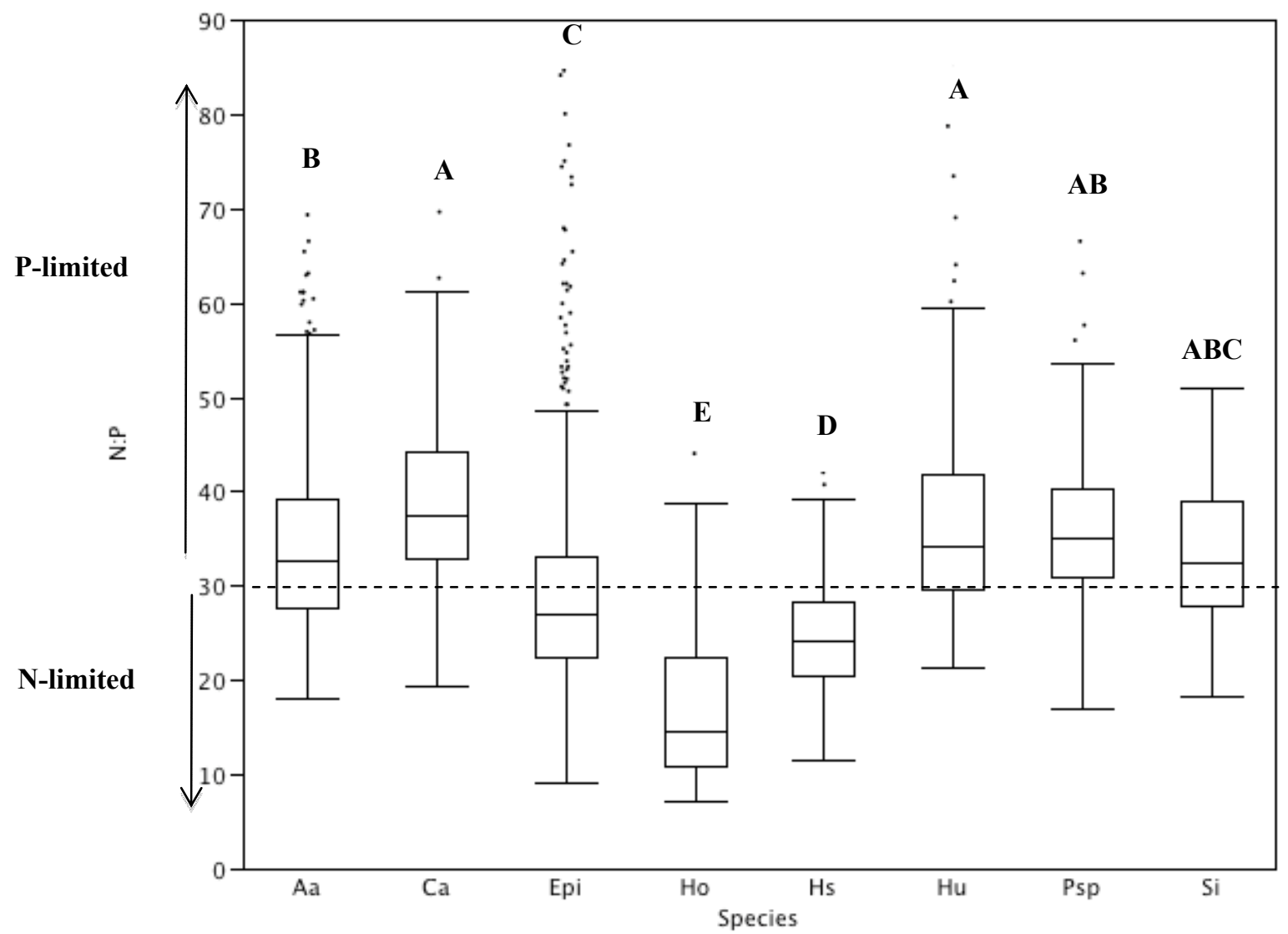

Figure 4c: Ratios of N:P for seven species of seagrass and epiphytes in Shark Bay, Australia during warm season. Boxes with the same letter indicate no significant differences at $\mathrm{P}<0.05$ for Tukey's test. Sample sizes are provided above Panel $a$. Aa $=$ Amphibolis antarctica, $\mathrm{Ca}=$ Cymodocea angustata, Epi $=$ epiphytes, $\mathrm{Ho}=$ Halophila ovalis, $\mathrm{Hs}=$ Halophila spinulosa $\mathrm{Hu}=$ Halodule uninervis. Psp $=$ Posidonia $\mathrm{sp}$ (primarily P. australis), $\mathrm{Si}=$ Syringodium isoetifolium . 

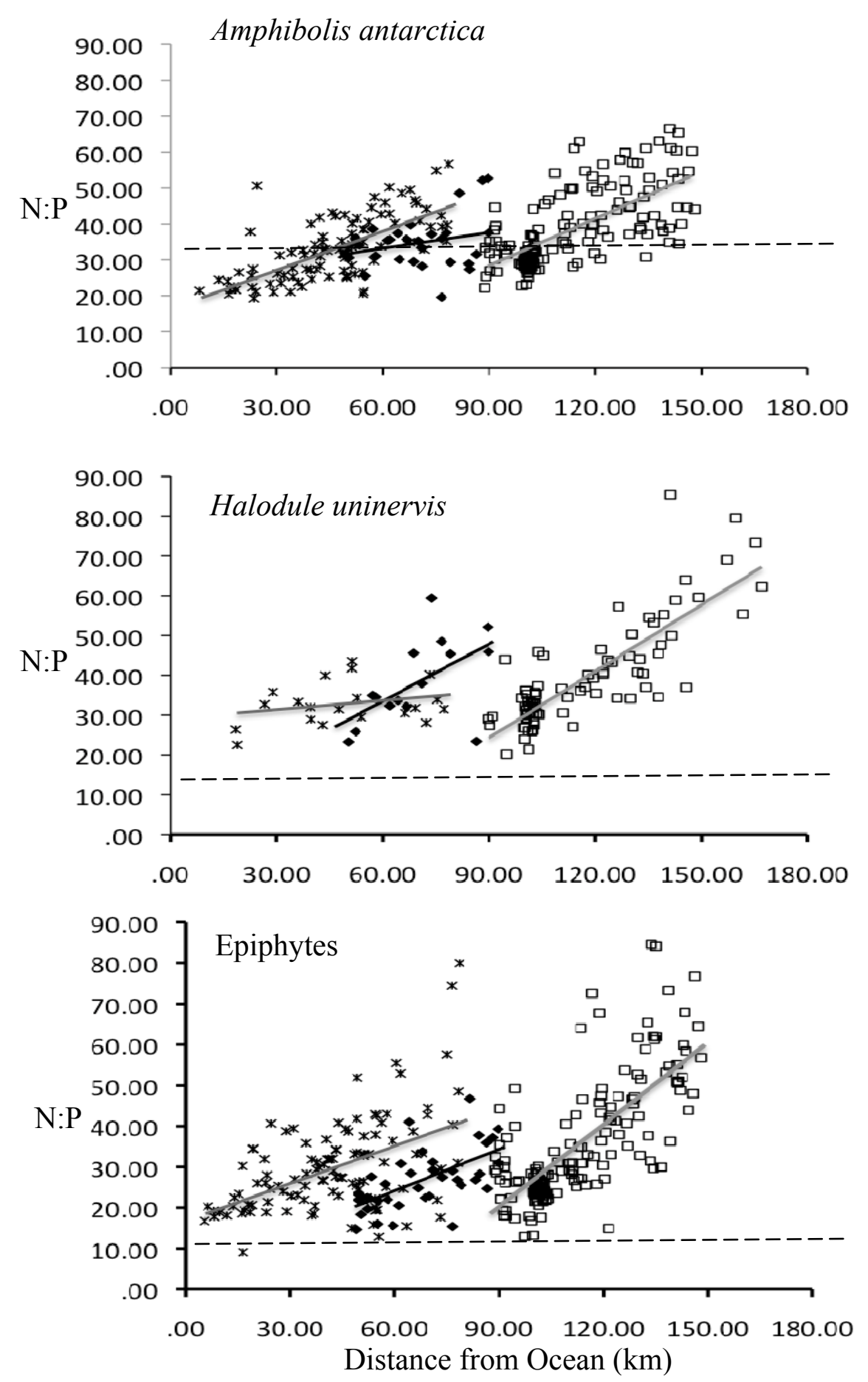

Figure 5: Regional variation in the influence of distance from the Indian Ocean on N:P ratios. *Western Gulf, $>$ = Northern Region, $\square$ = Eastern Gulf. Values above the dashed line suggest P-limitation while those below the line suggest N-limitation. See Table 3 for statistical results 


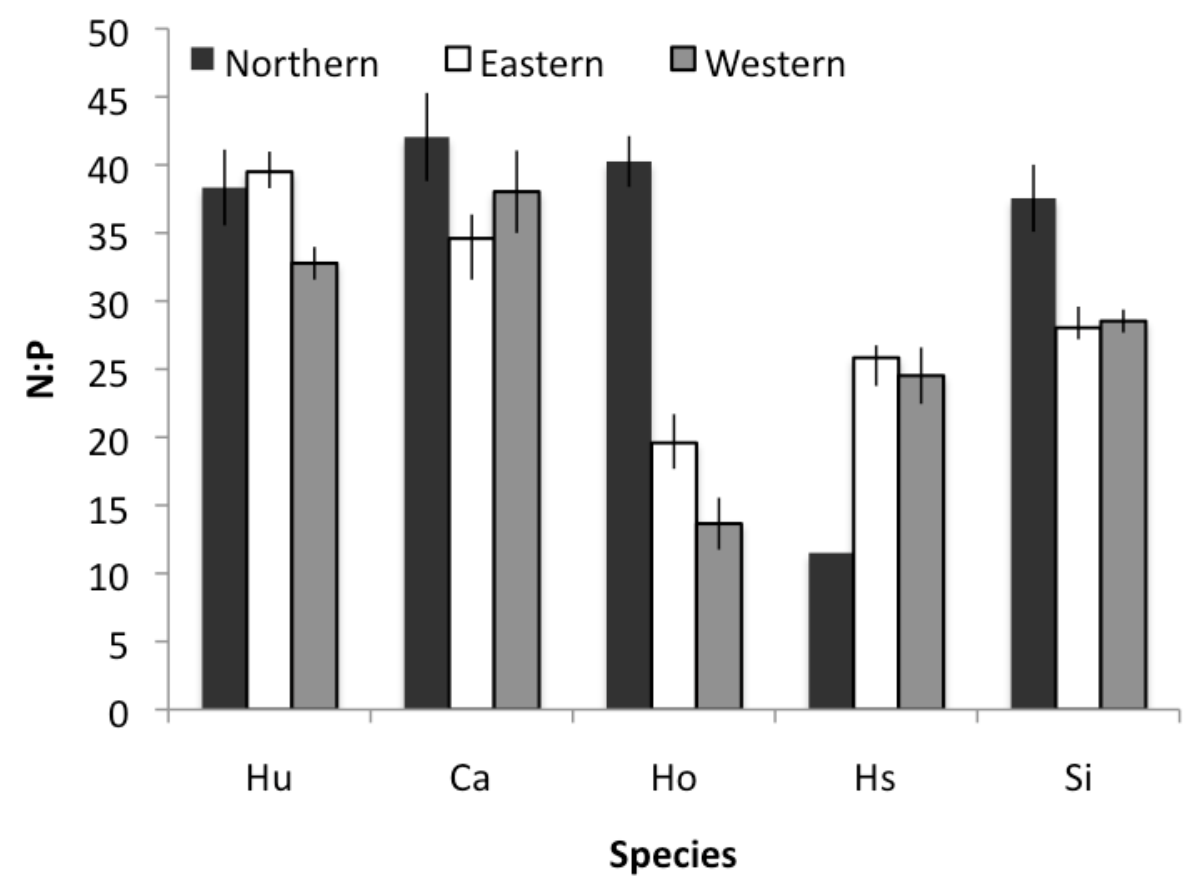

Figure 6a: Variation among regions in N:P ratios of seagrasses in Shark Bay. Only species with significant main effects and no significant interaction between region and distance are included (see Table 3). 


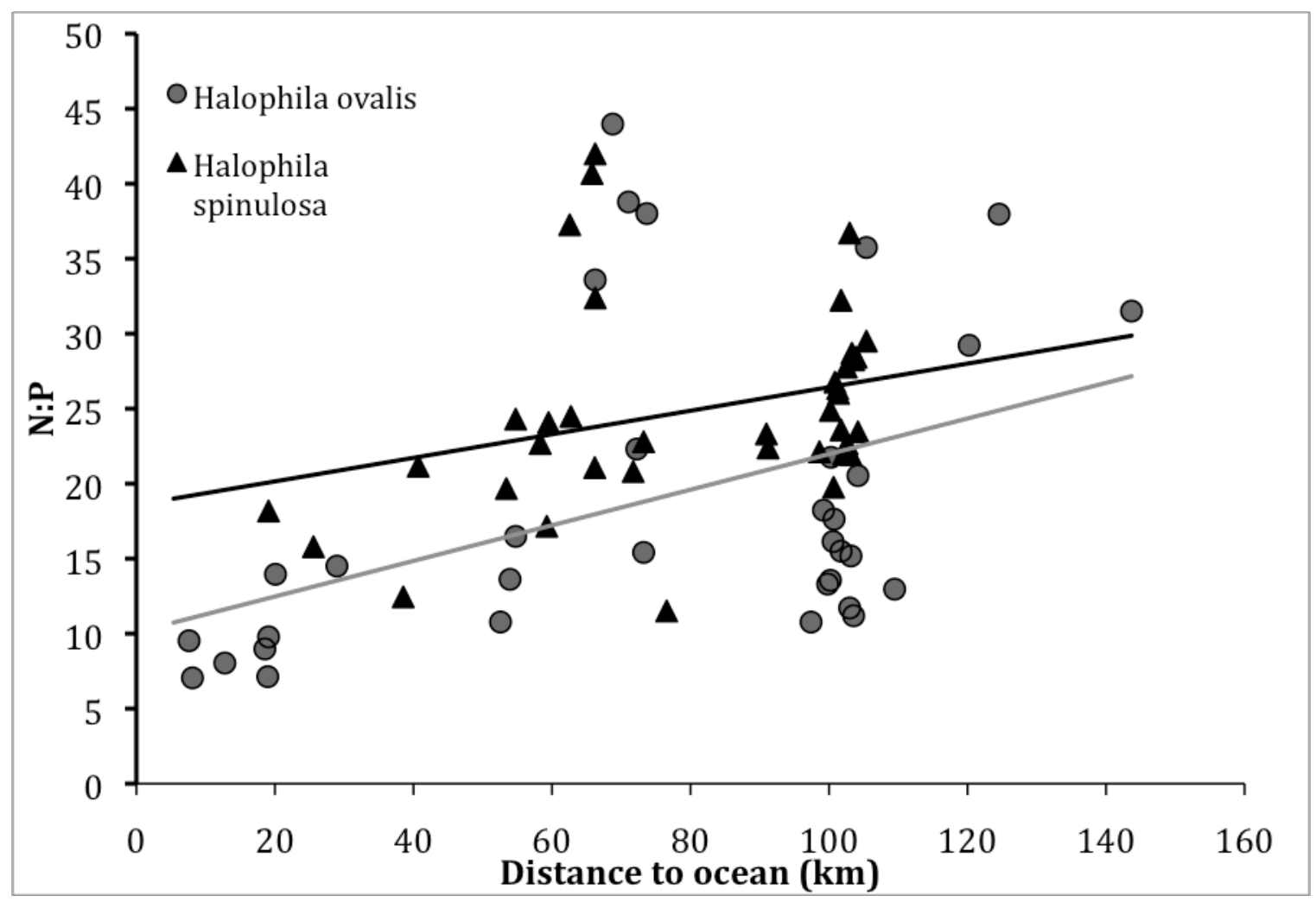

Figure 6b: Variation with distance from the Indian Ocean in N:P ratios of seagrasses in Shark Bay. Only species with significant main effects and no significant interaction between region and distance are included (see Table 3). 


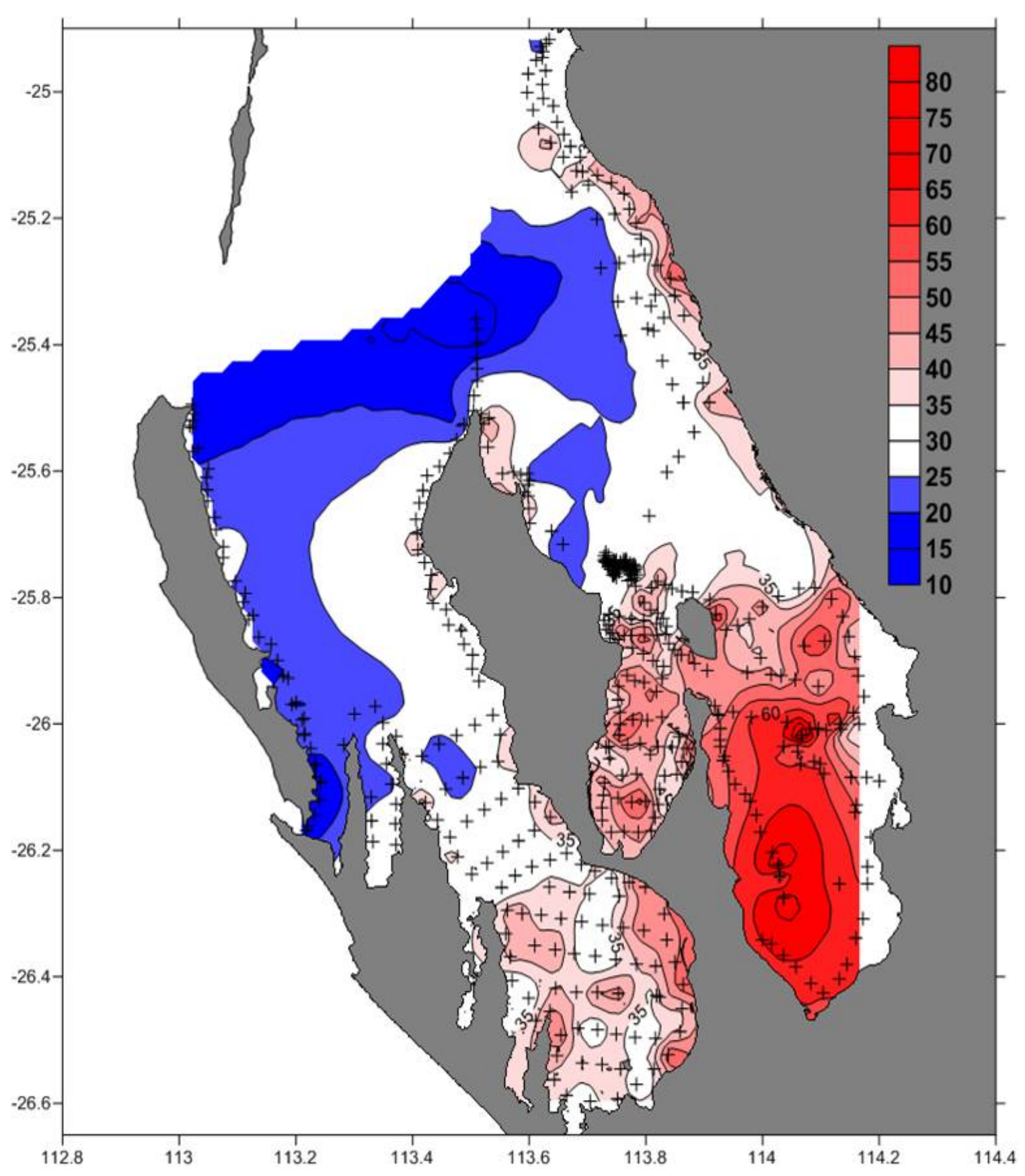

Figure 7: Isopleth of nutrient availability. Blue represents Nitrogen limitation, Red represents Phosphorus limitation, Regions plotted in white show no N:P values consistent with nutrient limitation. “+” symbols represent sample sites used for kriging map generation 


\section{Literature Cited}

Allegeier JE, Rosemond AD, Layman CA (2011) Variation in nutrient limitation and seagrass nutrient content in Bahamian tidal creek ecosystems. J Exp Mar Biol Ecol 407:330-336.

Armitage AR, Fourqurean JW (2006) The short-term influence of herbivory near patch reefs varies between seagrass species. J Exp Mar Biol Ecol 339: 65-74

Armitage AR, Frankovich TA, Fourqurean JW (2011) Long-term effects of adding nutrients to an oligotrophic coastal environment. Ecosystems 14: 430-444

Atkinson MJ (1987) Low phosphorus sediments in a hypersaline marine bay. Estuarine Coastal Shelf Sci 24: 335-347

Atkinson MJ, Smith SV (1983) C:N:P ratios of benthic marine plants. Limnol Oceanogr 28: $568-574$

Bjorndal KA (1980) Nutrition and grazing behavior of the green turtle, Chelonia mydas. Mar Biol 56: 147-154

Boyer KE, Fong P, Armitage AR, Cohen RA (2004) Elevated nutrient content of tropical macroalgae increases rates of herbivory in coral, seagrass, and mangrove habitats. Coral Reefs 23: 530-538

Burdige DJ, Zimmerman RC, Hu XP (2008) Rates of carbonate dissolution in permeable sediments estimated from pore-water profiles: The role of sea grasses. Limnol Oceanogr 53: 549-565

Burkholder DA, Heithaus MR, Fourqurean JW (In press) Feeding preferences of herbivores in a relatively pristine subtropical seagrass ecosystem. Mar Fresh Res

Campbell JE, Fourqurean JW (2009) Interspecific variation in the elemental and stable isotopic content of seagrasses in South Florida. Mar Ecol Prog Ser 387: 109-123

de Kanel J, Morse JW (1978) The chemistry of orthophosphate uptake from seawater onto calcite and aragonite. Geochim Cosmochim Acta 42: 1335-1340

Duarte CM (1990) Seagrass nutrient content. Mar Ecol Prog Ser 67: 201-207

Duarte CM (1991) Allometric scaling of seagrass form and productivity. Mar Ecol Prog Ser 77: $289-300$ 
Erftemeijer PLA (1994) Differences in nutrient concentrations and resources between seagarass communities on carbonate and terrigenous sediments in South Sulawesi, Indonesia. Bull Mar Sci 54:403-419

Ferdie M, Fourqurean JW (2004) Responses of seagrass communities to fertilization along a gradient of relative availability of nitrogen and phosphorus in a carbonate environment. Limnol Oceanogr 49: 2082-2094

Fourqurean JW, Moore TO, Fry B, Hollibaugh JT (1997) Spatial and temporal variation in C:N:P ratios, $\delta^{15} \mathrm{~N}$, and $\delta^{13} \mathrm{C}$ of eelgrass Zostera marina as indicators of ecosystem processes, Tomales Bay, California, USA. Mar Ecol Prog Ser 157:147157.

Fourqurean JW, Zieman JC, Powell GVN (1992) Phosphorus limitation of primary production in Florida Bay: Evidence from $\mathrm{C}: \mathrm{N}: \mathrm{P}$ ratios of the dominant seagrass Thalassia testudinum. Limnol Oceanogr 37: 162-171

Fourqurean JW, Zieman JC (2002) Seagrass nutrient content reveals regional patterns of relative availability of nitrogen and phosphorus in the Florida Keys, USA. Biogeochem 61: 229-245

Fourqurean JW, Escorcia SP, Anderson WT, Zieman JC (2005) Spatial and seasonal variability in elemental content, $\delta^{13} \mathrm{C}$, and $\delta^{15} \mathrm{~N}$ of Thalassia testudinum from south Florida and its implications for ecosystem studies. Estuaries 28: 447-461

Hanson CE, Pattiaratchi CB, Waite AM (2005) Sporadic upwelling on a downwelling coast: Phytoplankton responses to spatially variable nutrient dynamics off the Gascoyne region of Western Australia. Continental Shelf Res 25: 1561-1582

Harrison PJ, Hu MH, Yang YP, Lu X (1990) Phosphate limitation in estuarine and coastal waters of China. J Exp Mar Biol Ecol 140: 79-87

Heithaus MR (2004) Fish communities of seagrass meadows and associated habitats in Shark Bay, Western Australia. Bull of Mar Sci 75: 79-99

Heithaus MR, Frid A, Wirsing A, Bejder L, Dill LM (2005) The biology of sea turtles under risk from tiger sharks at a foraging ground. Mar Ecol Prog Ser 288: 285294.

Howarth RW (1988) Nutrient limitation of net primary production in marine ecosystems. Ann Rev Ecol Syst 19: 89-110

Jensen HS, Mcglathery KJ, Marino R, Howarth RW (1998) Forms and availability of sediment phosphorus in carbonate sand of Bermuda seagrass beds. Limnol Oceanogr 43: 799-810 
Jensen HS, Nielsen OI, Koch MS, De Vicente I (2009) Phosphorus release with carbonate dissolution coupled to sulfide oxidation in Florida Bay seagrass sediments. Limnol Oceanogr 54: 1753-1764

Johnson MW, Heck KL, Fourqurean JW (2006) Nutrient content of seagrasses and epiphytes in the northern Gulf of Mexico: evidence of phosphorus and nitrogen limitation. Aquat Bot 85: 103-111

Krom MD, Kress N, Brenner S, Gordon LI (1991) Phosphorus limitation of primary productivity in the eastern Mediterranean Sea. Limnol Oceanogr 36: 424-432

Long MH, Mcglathery KJ, Zieman JC, Berg P (2008) The role of organic acid exudates in liberating phosphorus from seagrass-vegetated carbonate sediments. Limnol Oceanogr 53: 2616-2626

Lotze HK, Lenihan HS, Bourque BJ, Bradbury RH, Cooke RG, Kay MC, Kidwell SM, Kirby MX, Peterson CH, Jackson JB (2006) Depletion, degradation, and recovery potential of estuaries and coastal seas. Science 312: 1806-1809

Nixon SW (1995) Coastal marine eutrophication - a definition, social causes and future concerns. Ophelia 41: 199-219

Orth RJ, Carruthers JB, Dennison WC, Duarte CM, Fourqurean JW, Heck Jr. KL, Hughes AR, Kendrick GA, Kenworthy WJ, Olyarnik S, Short FT, Waycott M, Williams SL (2006) A global crisis for seagrass ecosystems. Bioscience 56 (12): 987-996

Price RM, Skrzypek G, Grierson PF, Swart PK, Fourqurean JW (In Press) The use of stable isotopes of oxygen and hydrogen in identifying water exchange of in two hypersaline estuaries with different hydrologic regimes. Mar Fresh Res

Redfield AC (1958) The biological control of chemical factors in the environment. Am. Sci. 46: 205-221

Segal RD, Waite AM, Hamilton DP (2009) Nutrient limitation of phytoplankton in solar salt ponds in Shark Bay, Western Australia. Hydrobiologia 626: 97-109

Short FT, Davis MW, Gibson RA, Zimmermann CF (1985) Evidence for phosphorus limitation in carbonate sediments of the seagrass Syringodium filiforme. Estuarine Coastal Shelf Sci. 20: 419-430

Short FT, Wyllie-Echeverria S (1996) Natural and human-induced disturbance of seagrasses. Environmental Conservation 23: 17-27

Smith SV (1984) Phosphorus versus nitrogen limitation in the marine environment. Limnol Oceanogr 29: 1149-1160 
Smith SV, Atkinson MJ (1983) Mass balance of carbon and phosphorus in Shark Bay, Western Australia. Limnol Oceanogr 28: 625-639

Smith SV, Atkinson MJ (1984) Phosphorus limitation of net production in a confined aquatic ecosystem. Nature 307: 626-627

Sterner RW, and Elser JJ (2002) Ecological Stoichiometry: The Biology of Elements from Molecules to the Biosphere. Princeton University Press

Walker DI, Kendrick GA, McComb AJ (1988) The Distribution of Seagrass Species in Shark Bay, Western-Australia, with Notes on Their Ecology. Aquat Bot 30: $305-$ 317

Walker, DI, McComb, AJ (1988) Seasonal variation in the production, biomass and nutrient status of Amphibolis antarctica (Labill.) Sonder ex Aschers. and Posidonia australis hook.f. in Shark Bay, Western Australia. Aquat Bot 31: 259275.

Walker DI, Woelkerling WJ (1988) Quantitative study of sediment contribution by epiphytic coralline red algae in seagrass meadows in Shark Bay, Western Australia. Mar Ecol Prog Ser 43: 71-77

Waycott M, Duarte CM, Carruthers TJB, Orth RJ, Dennison WC, Olyarnik S, Calladine A, Fourqurean JW, Heck Jr. KL., Hughes AR, Kendrick GA, Kenworthy WJ, Short FT, Williams SL (2009) Accelerating loss of seagrasses across the globe threatens coastal ecosystems. Proc Natl Acad Sci USA 106(30): 12377-12381

Wulff F, Eyre BD, Johnstone R (2011) Nitrogen versus phosphorus limitation in a subtropical coastal embayment (Moreton Bay; Australia): Implications for management. Ecological Modeling 222: 120-130

Zieman JC, Wetzel RG (1980) Productivity in seagrasses: methods and rates. In: Phillips RC, and CP McRoy (eds). Handbook of seagrass biology, an ecosystem prospective. Garland STPM, New York, pp 87-116 
CHAPTER III

FEEDING PREFERENCES OF HERBIVORES IN A RELATIVELY PRISTINE SUBTROPICAL SEAGRASS ECOSYSTEM 


\begin{abstract}
Understanding forage choice of herbivores is important for predicting the potential impacts of changes in their abundance. Such studies, however, are rare in ecosystems with intact populations of both megagrazers (sirenians, sea turtles) and fish grazers. I used feeding assays and nutrient analyses of seagrasses to determine whether forage choice of grazers in Shark Bay, Australia were influenced by the quality of seagrasses. I found significant interspecific variation in removal rates of seagrasses across three habitats (shallow seagrass bank interior, shallow seagrass bank edge, deep), but I did not detect variation in gazing intensity among habitats. In general, grazers were more likely to consume fast-growing species with lower $\mathrm{C}: \mathrm{N}$ and $\mathrm{C}: \mathrm{P}$ ratios than the slower-growing species with higher $\mathrm{C}: \mathrm{N}$ and $\mathrm{C}: \mathrm{P}$ ratios that are dominant in the bay. Grazer choices were not, correlated with nutrient content of tropical seagrasses. Slowgrowing temperate seagrasses that experienced lower herbivory provide greater habitat value as a refuge for fishes and may facilitate fish grazing on tropical species. Further studies are needed, however, to more fully resolve the factors influencing grazer foraging preferences and the possibility that grazers mediate indirect interactions among seagrass species.
\end{abstract}




\section{Introduction}

Herbivores can play an important role in structuring primary producer communities in terrestrial, freshwater, and marine habitats. In marine settings, green turtles (Chelonia mydas; Bjorndal 1997; Moran and Bjorndal 2005; Fourqurean et al. 2010; Lal et al. 2010), dugongs (Dugong dugon; Aragones and Marsh 2000; deIongh et al. 1995; Preen 1995; Masini et al. 2001), and fishes (Kirsch et al. 2002, Tomas et al. 2005, Armitage and Fourqurean 2006) can modify the structure and biomass of seagrass communities. The relative importance of herbivory in structuring seagrass ecosystems, however, has traditionally been underappreciated, likely because populations of largebodied grazers have been greatly reduced in many ecosystems worldwide (e.g., Heck and Valentine 2007).

Understanding herbivore forage choice is critical for predicting ecosystem effects of changing population densities of herbivores. For example, experimental addition of nutrients or removal of herbivorous fish on Conch Reef in the Florida Keys resulted in increased algal cover, algal biomass, and suppressed cover of crustose coralline algae (Burkepile and Hay 2009). Around the fringing reefs of the Florida Keys, Sparisoma aurofrenatum, (redband parrotfish) selectively graze on the higher nutrient content, faster growing seagrass Halodule wrightii relative to lower-nutrient content, slower-growing Thalassia testudinum. Fish herbivory facilitates the dominance of T. testudinum in areas near reefs (Armitage and Fourqurean 2006). In addition to showing preference among functional forms and species of primary producers, the nutrient content of individual species can also influence the grazing rates of herbivores: parrotfishes prefer grazing on Thalassia testudinum with high $\mathrm{N}$ content compared to individuals with lower nitrogen 
(Goecker et al., 2005). In general, higher nitrogen and phosphorus content in primary producers is associated with higher grazing rates within and among species. For example, manipulating nutrient content of primary producers resulted in plots with higher nutrient content experiencing fish foraging rates 3 to 13 times higher than control plots (Burkepile and Hay 2009). Also, Boyer et al. (2004) found that increased tissue nitrogen and phosphorus of the macroalgae, Acanthophora spicifera, resulted in increased fish herbivory across several habitats (coral, seagrass and mangrove), with increases as high as $91 \%$ compared to un-enriched macroalgae in mangrove habitats. Such preferences for high-nutrient content also appear to drive preferences for particular species and can influence the composition of primary producer communities. For example, in the Wantamu Marine Park in Kenya, herbivorous fish foraged more on fast-growing seagrass species, including Cymodocea rotundata, with lower carbon content (i.e., low C:N) than on slow growing species with higher carbon fiber content (Mariani and Alcoverro 1999). Preferential grazing of highly palatable Halodule wrightii by juvenile parrotfish may help explain its relatively low abundance in Florida Bay and the Florida Keys compared to the less palatable Thalassia testudinum (Armitage and Fourqurean 2006). Similar preferences for fast-growing species with high $\mathrm{N}$ and $\mathrm{P}$ content have been suggested for both dugongs (deIongh et al. 1995; Preen 1995) and green turtles (Moran and Bjorndal 2005).

Feedbacks in grazed ecosystems can influence species composition of communities. For example, excavation grazing by dugongs facilitates the dominance of their preferred seagrass species because these high-nitrogen content species are fastgrowing (Preen 1995). Therefore, understanding forage choice of marine herbivores is 
important for predicting the consequences of changes in their abundance for primary producer communities. This may be particularly true for subtropical embayments, which can contain a diverse array of seagrass species with variable life-histories, nutrient content, and resilience to grazing disturbance. For example, the seagrass communities in Shark Bay, Western Australia, are a mix of slow-growing, low nutrient-content species of temperate origin (e.g. Amphibolis antarctica, Posidonia spp.) and more rapidly growing, high nutrient species of primarily tropical origin (e.g., Cymodocea sp., Halodule sp, Halophila sp.) (Walker et al. 1988, Burkholder et al. in press).

I set out to investigate whether the large populations of herbivores in Shark Bay which include dugongs, sea turtles and fishes - would selectively forage on high-nutrient content, fast growing tropical species when given a choice. Because the abundance of these large-bodied grazers in Shark Bay can vary in space and time (e.g., Heithaus 2004; Heithaus et al. 2007a; Wirsing et al. 2007a,b), I conducted forage choice assay trials across multiple habitat types.

\section{Materials and Methods}

Study Site

The study was conducted in the Eastern Gulf of Shark Bay, Western Australia $\left(\sim 25^{\circ} 45^{\prime} \mathrm{S}, 113^{\circ} 44^{\prime} \mathrm{E}\right)$. Located about 800 kilometers north of Perth, Shark Bay is a shallow $(<15 \mathrm{~m})$ subtropical bay dominated by extensive seagrass beds, which cover approximately 4,000 $\mathrm{km}^{2}$ (Walker et al. 1988). My study site in the Eastern Gulf is characterized by a series of shallow $(<4.5 \mathrm{~m})$ seagrass banks, separated by deeper channels $(6-11 \mathrm{~m})$ mostly covered by sand. Shallow habitats can be further subdivided 
into two microhabitats - interior portions of banks and bank edges - that vary in the abundance of some herbivorous species as well as seagrass community structure and biomass (see Heithaus et al. 2007a; Wirsing et al. 2007b; Burkholder et al. in press).

Shark Bay is perhaps one of the most pristine remaining seagrass ecosystems in the world and affords a unique opportunity to examine the effects of large herbivores on seagrass ecosystems (Heithaus et al. 2007b, 2008). Dominant herbivores in the system include green turtles (Chelonia mydas), dugongs (Dugong dugon), and teleosts (including the very common striped trumpeters, Pelates octolineatus; previously Pelates sexlineatus); these species likely are at or near population densities expected in the absence of anthropogenic impacts (Preen et al. 1997, Heithaus 2004, Heithaus et al. 2005). The seagrass community in my study area is a diverse assemblage. The dominant species, Amphibolis antarctica and Posidonia australis, are large and slow-growing. Small, fast-growing seagrasses, including Halophila ovalis, Halophila spinulosa, Halodule uninervis, Cymodocea angustata, Syringodium isoetifolium, Halophila decipiens and Halophila minor, are found in lower abundances (Walker et al. 1988, Burkholder et al. in press) than the dominant species. Duarte (1991) estimated that the leaf turnover rates (in units per year) for the species in my study at 3.86 units/year for Posidonia australis, 3.94 units/year for Amphibolis antarctica, 8.14 units/year for Cymodocea angustata, 13.87 units/year for Halodule uninervis, 20.85 units/year for Halophila ovalis, and 21.00 units/year for Halophila spinulosa. Relevant figures present species in order of growth rates from slowest to fastest. 


\section{Field Methods}

Because the abundance of megaherbivores (dugong and green sea turtle) and mesograzers (striped trumpeters) varies among habitats (deep vs. shallow) and within shallow ones (seagrass interior vs. seagrass edge) for at least megagrazers (see Heithaus 2004; Heithaus et al. 2007a; Wirsing et al. 2007a,b) I conducted a total of 35 forage preference assays across multiple habitats (shallow interior, bank edges, deep). Five assays were conducted during March 2007 and 30 were conducted February-March 2009. Each trial consisted of a series of servings of seagrasses (see below) that were woven into a $7 \mathrm{~mm}$, three-strand nylon rope with servings spaced every $50 \mathrm{~cm}$ along the line. Seagrasses were secured to the line with paperclips to stand vertically to simulate live seagrasses. The lines were placed over sand bottoms parallel to the edge of a seagrass patch at a distance of 1 meter from the sand/seagrass margin and secured to the sediment with bent metal wire stakes. For each trial, I included three replicate "servings" of each abundant seagrass species ( $\mathrm{n}=18$ total servings/trial - 3 replicates $\times 6$ seagrass species in 2007; $\mathrm{n}=15$ total servings/trial -3 replicates $\mathrm{x} 5$ seagrass species - in 2009). During 2007, I conducted all five trials in interior habitats using Halophila ovalis, Halophila spinulosa, Amphibolis antarctica, Posidonia australis, Halodule uninervis, and Cymodocea angustata. In 2009, I conducted 30 trials $(n=10 /$ habitat $)$ with all species used in 2009 except for Halophila spinulosa, which was not present in adequate abundances for collection in 2009 .

Prior to an assay, I collected leaves of all available seagrass species from one of two "donor beds" depending on seagrass species, and separated collections into replicate servings. Each serving was photographed individually with a numbered plate identifying 
the serving number and position in the line and a ruler making it possible to match leaves before and after trials. The number of leaves per serving varied across species in order to approximately match servings for total biomass (i.e. servings of species with large leaves contained fewer leaves than servings of species with small leaves). Three leaves were used for Posidonia australis, five leaves were used for Amphibolis antarctica, Halophila spinulosa, Halophila ovalis, Cymodocea angustata, and ten leaves were used for Halodule uninervis. Seagrass species order on each line was assigned haphazardly and the pattern was repeated for each of the three servings per species on an assay. Therefore, the nearest neighbors of a particular species varied across lines within habitats. Each assay was run for 24 hours and then the lines were removed. Servings were removed from the paperclips, laid flat and re-photographed, all leaf material (total serving) was assessed in the before and after photographs to calculate total percent leaf area lost. Although no specific controls were run during the time of herbivory assays, seagrass species used in this study were transplanted into cages that prevented herbivory for another study. All species maintained or increased their biomass (unpublished data), suggesting that the loss or damage to leaf material in this study was from herbivores and not handling.

In some systems, herbivores leave distinctive bite marks on seagrass leaves when they forage, for instance, bucktooth parrotfish, Sparisoma radians leave distinctive curved bitemarks (Goecker et al. 2005). I was unable to use such approaches in this study because dugongs and turtles would be expected to remove entire servings in many cases and stomach contents analysis of $P$. octolineatus suggests that rather than removing small bites from blades, it consumes the entire width of blades in many cases 
(unpublished data). Although I encountered some bitemarks of herbivorous fish on the larger seagrass species, smaller tropical species in this study exhibited marks that were characterized by large portions of the leaves missing and the bite consuming the entire width of the leaf. Such bites could be due to either turtle or fish herbivory. Behavioral observations while deploying assay lines suggest that herbivorous fish, specifically $P$. octolineatus may have played a significant role in seagrass removal for some seagrass species. Stomach content analysis of green sea turtles (Burkholder et al. 2011) and $P$. octolineatus (C. Bessey, unpublished data) in Shark Bay suggest they eat multiple species of seagrass including some Amphibolis antarctica.

I analyzed seagrasses collected from donor beds between 2007 and 2009 to determine nutrient content. At least five shoots were collected for each species. All samples were stored on ice in the field and immediately frozen to $-20^{\circ} \mathrm{C}$ upon return to shore. Samples remained frozen until they could be processed.

\section{Laboratory Methods}

Seagrass samples for elemental analysis were thawed, rinsed in deionized (DI) water, and each leaf was gently scraped with a razorblade to remove all epibiota. I separated leaves from stems and belowground tissue (roots and rhizome) and restricted my analysis to leaf tissue of each species. Leaves from each of the five plants collected for each site were dried using a food dehydrator (Ezidri Ultra FD1000) for at least 24 hours. Once dry, samples were crushed into powder for analysis using mortar and pestle. Carbon (C) and nitrogen (N) content of samples were measured using an elemental 
analyzer (Fisons NA1500, United Kingdom) and phosphorus (P) content was measured using a dry-oxidation/acid hydrolysis method (Fourqurean et al. 1992).

Analyses

I investigated species differences in elemental composition (C:N, C:P) of seagrasses at the sites from which the plans were collected (i.e., donor beds) to determine whether herbivore preferences might partially be explained by interspecific variation in nutrient composition. These included Amphibolis antarctica, Posidonia australis, Halodule uninervis, and Cymodocea angustata samples from edge habitat and Halophila ovalis and H. spinulosa samples from deep habitats. Only samples from warm months (October-May) were included in analyses since nutrient content can vary seasonally (Fourqurean et al. 2005) and my trials were conducted during these times.

Because it is difficult to ensure that all leaves of certain seagrass species are perfectly flat during photographs and extensive handling could damage seagrass leaves, I estimated the proportion of leaf area lost for each serving by comparing photographs of each serving before and after a trial. All serving photographs were viewed by five independent observers who recorded the estimated percent area loss during the trial. For analyses, I used the average estimated percent loss for each serving across the five observers and then collapsed the data for the three servings of each species in each trial to a single mean value. This accounted for non-independence of the three replicate servings within an assay line.

I used a conditional approach to analyses because of the large number of zeros in the dataset. In this approach, I first conducted a logistic regression to investigate 
variation in the probability that any of the three servings were grazed at all on a line. Then, I used ANOVA on arcsin square-root transformed data to investigate factors affecting the proportion of seagrass removed from servings if any grazing occurred during the trial (i.e., I did not include zeros in the dataset). Because of differences in species used during the two years of trials I analyzed these data separately. In 2007, I only investigated variation among species of seagrasses (because all trials occurred within interior microhabitats). In 2009, I investigated the effects of species, microhabitat (interior, edge, deep) and their interaction. The interaction term was removed and the model re-run if $\mathrm{P}>0.10$. Although individual lines may experience different overall levels of herbivory, I did not account for non-independence of species within a line because variance in overall herbivory pressure among lines should obscure results and non-parametric tests (e.g., Friedman's test) do not allow for independent contrasts among species.

\section{Results}

There was significant variation among seagrasses in C:N and C:P ratios $\left(\mathrm{F}_{5,289}=\right.$ 59.4, $\mathrm{P}<0.0001, \mathrm{~F}_{5,289}=49.7, \mathrm{P}<0.0001$, respectively). Nitrogen content was higher in all of the faster growing species than in Amphibolis or Posidonia, with Cymodocea and Halodule having the highest relative nitrogen content (Figure 1a). Similarly, phosporus concentration was lowest (i.e., highes C:P ratios) in Amphibolis and Posidonia and highest in Halophila ovalis (Figure 1b). All other species had similar, and intermediate, values. 
In 2007 in interior habitats, there was significant variation among species in the probability that at least one serving of a species would be grazed $\left(\chi^{2}=19.9, \mathrm{df}=5, \mathrm{P}=\right.$ $0.001)$ and the proportion of leaf area that was removed if grazing occurred $\left(\mathrm{F}_{5,47}=15.7\right.$, $\mathrm{P}<0.0001$ ). Halophila spinulosa and Halodule uninervis always had at least one serving grazed and Amphibolis antarctica and Posidonia australis were grazed relatively infrequently (Figure 2a). When grazed, H. spinulosa experienced the greatest amount of leaf area loss followed by H. uninervis (Figure 2b).

During 2009, the probability that at least one serving of a species was grazed during a trial varied among species $\left(\chi^{2}=40.9, \mathrm{df}=4, \mathrm{P}<0.0001\right)$. There were not statistically significant differences in species removed across habitats $\left(\chi^{2}=3.9, \mathrm{df}=2, \mathrm{P}\right.$ $=0.14)$ and I did not detect an effect of the interaction between habitat and seagrass species $\left(\chi^{2}=10.4, \mathrm{df}=8, \mathrm{P}=0.24\right)$. Halodule uninervis and Halophila ovalis were the most likely to be grazed and Amphibolis antarctica and Posidonia australis were the least likely to be grazed, but probabilities of at least some grazing occurring was higher for these temperate species in 2009 than they were in 2007 (Figure 3a). The amount of seagrass removed from servings that were grazed varied among species $\left(\mathrm{F}_{4,111}=13.60, \mathrm{P}\right.$ $<0.0001)$, but there was no statistically significant effect of habitat $\left(\mathrm{F}_{2,111}=0.5, \mathrm{P}=0.59\right)$ or the interaction of seagrass species and habitat $\left(\mathrm{F}_{8,111}=1.0, \mathrm{P}=0.42\right)$. Halodule uninervis and Halophila ovalis had substantially higher proportions of servings removed than the three other species, which did not differ significantly (Figure 3b). 


\section{Discussion}

In the relatively pristine seagrass ecosystem of Shark Bay, fast-growing, smaller, high nutrient content seagrasses were consumed by herbivores at a faster rate than slowgrowing, larger, low nutrient content seagrasses. For the individual seagrass species, removal rates of seagrass species were generally similar across years in warm seasons and did not appear to vary across habitat types. The lack of detected spatial variation, however, may be explained by relatively low sample sizes, the short duration of trials, the relative importance of fish grazing, or grazing saturation on some species thus limiting the ability to detect more intense grazing. Unfortunately, I could not identify the species responsible for grazing on my seagrass servings, which makes it impossible to determine species-specific foraging patterns with my data. It is unlikely that all three grazer types (sea turtle, sirenians and teleosts) contributed equally to observed removals because of variation in their abundance and the likelihood that fish, turtles, and dugongs respond differently to the sizes of servings in my assays. Although at the outset of the study I assumed that most grazing would be by green turtles and dugongs, it appears that the teleost Pelates octolineatus likely was responsible for most grazing. Teleost grazing is supported by observations of $P$. octolineatus removing entire servings of $H$. spinulosa before an assay was completely deployed (personal observation), observations of seagrasses in $P$. octolineatus stomachs (unpublished data), fatty acid analysis consistent with substantial seagrass herbivory in $1 / 3$ of the surveyed $P$. octolineatus in the study area (Belicka et al. in press), and the presence of partially removed servings in many situations. I would have expected turtles or dugongs to have completely, or largely, removed individuals servings. The relatively small servings probably are more likely to 
attract teleosts than turtles or dugongs and future studies should include video recording of trials as well as designs that might be more likely to attract turtles and dugongs.

The expectation that fast-growing species, with higher $\mathrm{N}$ and $\mathrm{P}$ content, would be grazed more heavily than slow-growing lower quality forage species (Amphibolis and Posidonia) was generally upheld during my study. Variation in grazing patterns on fastgrowing species are harder to explain. Cymodocea angustata had the highest nitrogen content along with Halodule uninervis while Halophila ovalis had the highest phosphorus content. Cymodocea angustata, however, experienced the least grazing of the fastergrowing species while Halophila spinulosa experienced the heaviest grazing despite having lower $\mathrm{N}$ and $\mathrm{P}$ content than several other species (Table 1). Nutrient content and more specifically nitrogen content (food quality) is only one factor that may drive herbivore forage choices. Many marine plants employ both morphological and chemical defenses that may reduce their palatability or forage quality to herbivores. These include morphological defenses like concentrated compounds in cell walls or increased fiber content making them hard to digest (Fritz and Simms 1992). Plant chemical defenses also can play an important role in herbivore food choice. Condensed tannins which can effect protein-binding properties of the plant material making proteins less available to consumers, or phenolic compounds can reduce palatability or even increase toxicity to herbivores (Arnold et al. 1995. Hagerman et al. 1992, Jones and Hangan 1977, Hay et al. 1987, Hay and Fenical 1988, Robbins et al. 1987, McMillan 1984). In addition, epibiotic growth can also impact herbivory on marine plants (Wahl and Hay 1995, Karez et al. 2000, Jormalaienen et al. 2008). 
Grazer type also may affect how they select food types. For example, obligate herbivores appear to select potential foods on the basis of nutrient content, while omnivorous grazers may use other cues like leaf manipulability and/or visual recognition of resources (Prado and Heck 2011). Pelates octolineatus, the numerically dominant fish grazer in the study area, is omnivorous (unpublished data). Therefore, the high rate of removal of $H$. spinulosa may be a result, in part to its morphology which is more susceptible to complete removal of leaf tissue than other tropical species. Indeed, during all trials in 2007 - the only year H. spinulosa was present in densities sufficient for grazing trials - grazers consumed at least a portion of H. spinulosa and Halodule uninervis during all trials and more than $70 \%$ of trials exhibited grazing on Halophila ovalis and Cymodocea angustata servings. Halophila spinulosa, however, exhibited higher proportions of leaf area removed from servings that were removed. The high rates of removal of fast-growing species raises the possibility that herbivores could be important in structuring seagrass communities in Shark Bay. Indeed, H. spinulosa was only observed in high abundances in the study area are for relatively brief times after a storm event, and grazing on this highly preferred seagrass species could be responsible for observed declines in its abundance. Further work is needed to test this hypothesis.

The least grazed species in my study - Amphibolis antarctica and Posidonia australis - are by far the dominant species in my study area (Burkholder et al. in press). Amphibolis antarctica, especially, forms large, dense, monospecific stands which can have canopy heights over one meter. In a manner similar to the role that reefs can play in other nearshore ecosystems, the structural complexity of the dense $A$. antarctica canopies provides shelter for Pelates octolineatus (Heithaus 2004) and, therefore, may 
facilitate herbivory on more palatable tropical seagrasses in shallow habitats. Such apparent competition (i.e., negative effect of one species on another through the actions of a shared consumer; Holt 1977) among seagrass species may be an important feature in seagrass community dynamics in Shark Bay. Grazers do not, however, completely avoid A. antarctica as a food source. Despite removing biomass of more palatable species during assays, some $A$. antarctica was consumed and observations of both green turtle and dugong foraging (e.g., Wirsing et al. 2007c) as well as stomach contents of striped trumpeters (C. Bessey, unpublished data) show that $A$. antarctica is a component of their diets. Future trials, including those that incorporate video to identify grazers, larger sample sizes, trials in multiple seasons, as well as competition experiments between fastgrowing and slow-growing species likely will provide interesting new insights into grazing dynamics in the bay.

Seagrasses stabilize coastal habitats, provide primary productivity and food for a system, and can serve as habitat for numerous invertebrates and fish species. Not all species, however, provide the same overall ecosystem services or value. For example, species composition of seagrass meadows in Florida Bay strongly influence the structure and abundance of fish communities (Matheson et al. 1999). Because some seagrass species are preferred by herbivores over others and these herbivores can have large impacts on seagrass community structure, it is important that managers incorporate an understanding of herbivore forage preferences and habitat use into management strategies. While understanding forage preferences may not be as important in temperate environments where single seagrass species make up seagrass beds (e.g., Zostera marina in the North Atlantic temperate zone), it could be very important in areas with high 
seagrass species diversity like the subtropical embayments of Shark Bay or Florida Bay where different management strategies can influence the species composition of seagrass beds in subtropical ecosystems (Herbert et al. 2011, and Fourqurean et al. 2003).

\section{Acknowledgements}

I would like to thank the Monkey Mia Dolphin Resort for providing lodging and logistical support throughout this study. A special thank you to my dedicated field assistants that made the project possible. Funding for this project was provided by the U.S. National Science Foundation (NSF) grants OCE0526065 and OCE0745606 to M. Heithaus, an FIU Dissertation Evidence Acquisition Fellowship, and an FIU Dissertation Year Fellowship to D. Burkholder. Publication of this paper was facilitated by a supplement to the Florida Coastal Everglades Long-Term Ecological Research Project funded by NSF (DBI0620409). I thank Jopalo Boats, Bombadier Recreation Products, Humminbird, The Airline, and Submersible Systems for significant donations in the form of discounts on boats and equipment. Research was conducted under DEC permit numbers: CE002300, SW012509, CE001685 and subsequent annual renewals. This is contribution \#x from the Shark Bay Ecosystem Research Project and \#x from the Southeast Environmental Research Center at Florida International University. 


\section{Literature Cited}

Aragones, L. V., and Marsh, H. (2000). Impact of dugong grazing and turtle cropping on tropical seagrass communities. Pacific Conservation Biology 5: 277-288.

Armitage, A. R., and Fourqurean, J. W. (2006). The short-term influence of herbivory near patch reefs varies between seagrass species. Journal of Experimental Marine Biology and Ecology 339(1): 65-74.

Arnold, T. M., Tanner, C. E., and Hatch, W. I. (1995). Phenotypic variation in polyphenolic content of the tropical brown algae Lobophora variegata as a function of nitrogen availability. Marine Ecology Progress Series 123: 177-183.

Belicka, L. L., Burkholder, D. A., Fourqurean, J. W., Heithaus, M. R., Macko, S. A., and Jaffe, R. (In Press). Stable isotope and fatty acid biomarkers of seagrass, epiphytic, and algal organic matter of consumers in a nearly pristine seagrass ecosystem. Marine and Freshwater Research.

Bjorndal, K. A. (1997). Foraging ecology and nutrition of sea turtles. In 'The biology of sea turtles', (Eds. P. L. Lutz \& J. A. Musick), pp. 199-231. (Boca Raton: CRC Press)

Boyer, K. E., Fong, P., Armitage, A. R., and Cohen, R. A. (2004). Elevated nutrient content of tropical macroalgae increases rates of herbivory in coral, seagrass, and mangrove habitats. Coral Reefs 23(4): 530-538.

Burkepile, D. E., and Hay, M. E. (2009). Nutrient versus herbivore control of macroalgal community development and coral growth on a Caribbean reef. Marine Ecology Progress Series 389: 71-84.

Burkholder, D. A., J. W. Fourqurean, and M. R. Heithaus. (In press). Spatial pattern in seagrass stoichiometry indicates both $\mathrm{N}$-limited and P-limited regions of an iconic P-limited subtropical bay. Marine Ecology Progress Series DOI: 10.3354/meps 10042

Burkholder, D. A., Heithaus, M. R., Thomson, J. A., and Fourqurean, J. W. (2011). Diversity in trophic interactions of green sea turtles Chelonia mydas on a relatively pristine coastal foraging ground. Marine Ecology Progress Series 439: 277-293.

de Iongh, H. H., Wenno, B. J., and Meelis, E. (1995). Seagrass distribution and seasonal biomass changes in relation to dugong grazing in the Moluccas, East Indonesia. Aquatic Botany 50: 1-19. 
Duarte, C. M. (1991). Allometric scaling of seagrass form and productivity. Marine Ecology Progress Series 77: 289-300.

Fourqurean, J. W., Boyer, J. N., Durako, M. J., Hefty, L. N., and Peterson, B. J. (2003). Forecasting responses of seagrass distributions to changing water quality using monitoring data. Ecological Applications 13: 474-489.

Fourqurean, J. W., Escorcia, S. P., Anderson, W. T., and Zieman, J. C. (2005). Spatial and seasonal variability in elemental content, $\delta^{13} \mathrm{C}$, and $\delta^{15} \mathrm{~N}$ of Thalassia testudinum from south Florida and its implications for ecosystem studies. Estuaries 28, 447-461

Fourqurean, J. W., Manuel, S., Coates, K. A., Kenworthy, J. W., and Smith, S. R. (2010). Effects of excluding sea turtle herbivores from a seagrass bed: Overgrazing may have led to loss of seagrass meadows in Bermuda. Marine Ecology Progress Series 419: 223-232.

Fourqurean, J.W., Zieman, J.C., Powell, G.V.N. (1992). Phosphorus limitation of primary production in Florida Bay: Evidence from $\mathrm{C}: \mathrm{N}: \mathrm{P}$ ratios of the dominant seagrass Thalassia testudinum. Limnology and Oceangraphy 37: 162-171.

Fritz, R., and Simms, E. (1992). Plant resistance to herbivores and pathogens: ecology evolution and genetics. University of Chicago Press, Chicago.

Goecker, M. E., Heck, K. L., and Valentine, J. F. (2005). Effects of nitrogen concentrations in turtlegrass Thalassia testudinum on consumption by the bucktooth parrotfish Sparisona radians. Marine Ecology Progress Series 286: 239-248.

Hagerman, A. E., Robbins, C. T., Weerasuriya, Y., Wilson, T. C., McArthur, C. (1992). Tannin chemistry in relation to digestion. Journal of Range Management 45: $57-62$.

Hay, M. E., and Fenical, W. (1988). Marine plant-herbivore interactions: the ecology of chemical defense. Annual Review of Ecology and Systematics 19: 111-145.

Hay, M. E., Fenical, W., and Gustafson, K. (1987). Chemical defense against divers coral-reef herbivores. Ecology 68: 1581-1591.

Heck, K. L., and Valentine, J. F. (2007). The primacy of top-down effects in shallow benthic ecosystems. Estuaries and Coasts 30: 371-381. 
Heithaus, M. R. (2004). Fish communities of seagrass meadows and associated habitats in Shark Bay, Western Australia. Bulletin of Marine Science 75: 7999.

Heithaus, M. R., Frid, A., Wirsing, A., Bejder, L., Dill, L. M. (2005). The biology of green and loggerhead turtles under risk from tiger sharks at a foraging ground. Marine Ecology Progress Series 288: 285-294.

Heithaus, M. R., Frid, A. Wirsing, A. J., Dill, L. M., Fourqurean, J., Burkholder, D. Thomson, J. and Bejder, L. (2007a). State-dependent risk-taking by green sea turtles mediates top-down effects of tiger shark intimidation in a marine ecosystem. Journal of Animal Ecology 76: 837-844.

Heithaus, M. R., Wirsing, A. J., Frid, A., Dill, L. M. (2007b). Species interactions and marine conservation: Lessons from an undisturbed ecosystem. Israel Journal of Ecology and Evolution 53: 355-370.

Heithaus, M. R., A. Frid, A. J. Wirsing, and B. Worm. (2008). Predicting ecological consequences of marine top predator declines. Trends in Ecology and Evolution 23, 202-210

Herbert, D. A., Perry, W. B., Cosby, B. J., Fourqurean, J. W. (2011). Projected reorganization of Florida Bay seagrass communities in response to the increased freshwater inflow of Everglades restoration. Estuaries and Coasts 34: 973-992.

Holt, R. D. (1977). Predation, apparent competition, and structure of prey communities. Theoretical Population Biology 12:197-229.

Jones, W. T., and Mangan, J. L. (1977). Complexes of the condensed tannins of sainfoin (Onobrychis vicifolia Scop.) with fraction 1 leaf protein and with submaxillay mucoprotein, and their reversal by polyethylene glycol and $\mathrm{pH}$. Journal of the Science of Food and Agriculture 28: 126-136.

Jormalainen, V., Wikstrom, S. A. and Honkanen, T. (2008). Fouling mediates grazing: intertwining of resistances to multiple enemies in the brown alga Fucus vesiculosus. Oecologia 155: 559-569.

Karez R., Engelbert, S., and Sommer, U. (2000). 'Co-consumption' and 'protective coating': two new proposed effects of epiphytes on their macroalgal hosts in mesograzer0epiphyte-host interactions. Marine Ecology Progress Series 205: 8593.

Kirsch, K. D., Valentine, J. F., and Heck, K. L. Jr. (2002). Parrotfish grazing on turtlegrass, Thalassia testudinum: evidence for the importance of seagrass 
consumption in food web dynamics of the Florida Keys National Marine Sanctuary. Marine Ecology Progress Series 227: 71-85.

Lal, A., Arthur, R., Marbá, N., Lill, A. W. T., and Alcoverro, T. (2010). Implications of conserving an ecosystem modifier: Increasing green turtle (Chelonia mydas) densities substantially alters seagrass meadows. Biological Conservation 143: 2730-2738.

Mariani, S., and Alcoverro, T. (1999). A multiple-choice feeding-preference experiment utilizing seagrasses with a natural population of herbivorous fishes. Marine Ecology Progress Series 189: 295-299.

Masini, R. J., Anderson, P. K., and McComb, A. J. (2001). A Halodule-dominated community in a subtropical embayment: physical environment, productivity, biomass, and impact of dugong grazing. Aquatic Botany 71: 179-197.

Matheson, R. E. J., Camp, D. K., Sogard, S. M., Bjorgo, K. A. (1999). Changes in seagrass-associated fish and crustacean communities of Florida Bay mud banks: the effects of recent ecosystem changes? Estuaries 22: 534-551.

McMillan, C, (1984). The condensed tannins (proanthocyanidins) in seagrasses. Aquatic Botany. 20: 351-357.

Moran, K. L., and Bjorndal, K. A. (2005). Simulated green turtle grazing affects structure and productivity of seagrass pastures. Marine Ecology Progress Series 305: $235-247$.

Prado, P., and Heck, K. L. (2011). Seagrass selection by omnivorous and herbivorous consumers: determining factors. Marine Ecology Progress Series 429, 45-55.

Preen, A. R. (1995). Impacts of dugong foraging on seagrass habitats: observational and experimental evidence for cultivation grazing. Marine Ecology Progress Series 124: 201-213.

Preen, A. R., Marsh, H. D., Lawler, I. R., Prince, R. I., and Shepherd, R. (1997). Distribution and abundance of dugongs, turtles, dolphins and other megafauna in Shark Bay, Ningaloo Reef and Exmouth Gulf, Western Australia. Wildlife Research 24(2): 185-208.

Robbins, C. T., Hanley, T. A., Hagerman, A. E., Hjeljord, O., Baker, D. L., Schwartz, C. C., and Mautz, W. W. (1987). Role of tannins in defending plants against ruminants: reduction in protein availability. Ecology 68: 98-107. 
Tomas, F., Turon, X., and Romero, J. (2005). Seasonal and small-scale spatial variability of herbivory pressure on the temperate seagrass Posidonia oceanica. Marine Ecology Progress Series 301: 95-107.

Wahl, M., and Hay, M. E. (1995). Associational resistance and shared doom-effects of epibiosis on herbivory. Oecologia 102: 329-340.

Walker, D. I., Kendrick, G.A., and McComb, A. J. (1988). The distribution of seagrass species in Shark Bay, Western Australia, with notes on their ecology. Aquatic Botany 30: 305-317.

Wirsing, A. J., Heithaus, M. R., and Dill, L. M. (2007a). Fear factor: Do dugongs (Dugong dugon) trade food for safety from tiger sharks (Galeocerdo cuvier)? Oecologia 153: 1031-1040.

Wirsing, A. J., Heithaus, M. R., and Dill, L. M. (2007b). Living on the edge: dugongs prefer to forage in microhabitats that allow escape from rather than avoidance of predators. Animal Behavior 74, 93-101.

Wirsing, A. J., Heithaus, M. R. and Dill, L. M. (2007c). Can you dig it? Use of excavation, a risky foraging tactic, by dugongs is sensitive to predation danger. Animal Behavior 74, 1085-1091. 
Table 1: Relationship between estimated proportion of leaf area removed (i.e. proportion grazed at all * mean area removed when grazed), mean C:N, and mean C:P content of seagrass species. $\mathrm{Aa}=$ Amphibolis antarctica, $\mathrm{Ca}=$ Cymodocea angustata, $\mathrm{Hu}=$ Halodule uninervis, $\mathrm{Ho}=$ Halophila ovalis, $\mathrm{Hs}=$ Halophila spinulosa, $\mathrm{Pa}=$ Posidonia australis.

$\begin{array}{ccccc}\text { Species } & \text { Year } & \mathbf{C}: \mathbf{N} & \mathbf{C : P} & \begin{array}{c}\text { Estimated } \\ \text { prop } \\ \text { removed }\end{array} \\ \mathrm{Aa} & 2007 & 34.56 & 1071.62 & 0.001 \\ \mathrm{Ca} & 2007 & 21.13 & 746.35 & 0.016 \\ \mathrm{Hu} & 2007 & 20.99 & 682.23 & 0.215 \\ \mathrm{Ho} & 2007 & 21.09 & 359.92 & 0.087 \\ \mathrm{Hs} & 2007 & 25.68 & 666.25 & 0.518 \\ \mathrm{~Pa} & 2007 & 33.84 & 1102.28 & 0.002 \\ \mathrm{Aa} & 2009 & 34.56 & 1071.62 & 0.015 \\ \mathrm{Ca} & 2009 & 21.13 & 746.35 & 0.033 \\ \mathrm{Hu} & 2009 & 20.99 & 682.23 & 0.143 \\ \mathrm{Ho} & 2009 & 21.09 & 359.92 & 0.127 \\ \mathrm{~Pa} & 2009 & 33.84 & 1102.28 & 0.011\end{array}$




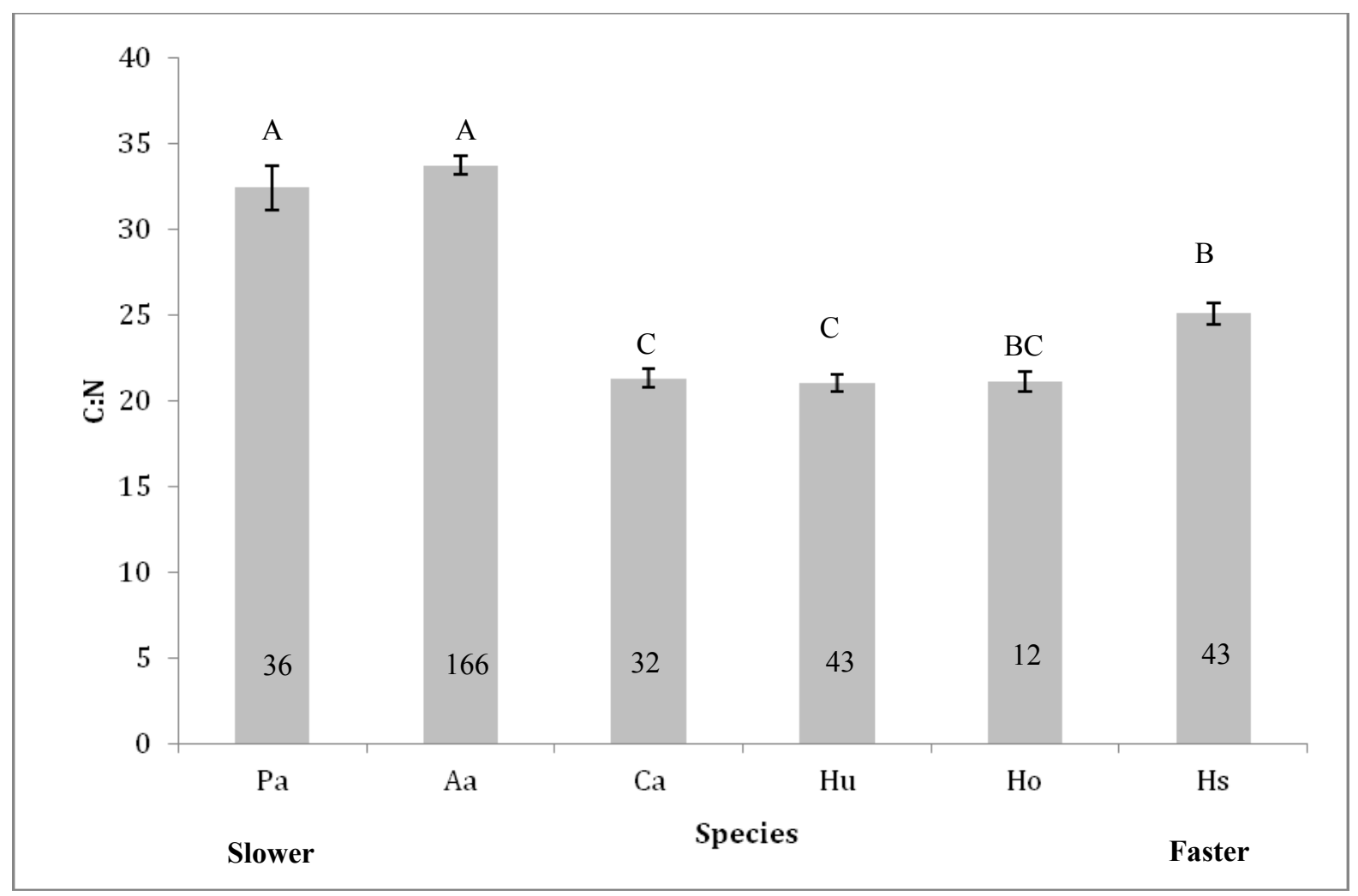

Figure 1a: Interspecific variation in $\mathrm{C}: \mathrm{N}$ ratios of seagrasses collected for feeding preference trials. Error bars are +/- SE. Bars labeled with the same letter are not statistically different from one another. Note, that lower values should indicate species of greater quality from an herbivores perspective (i.e. higher relative $\mathrm{N}$ or $\mathrm{P}$ content). Seagrass species are arranged along the X-axis based on leaf turnover rates from slowest to fastest. $\mathrm{Aa}=$ Amphibolis antarctica, $\mathrm{Ca}=$ Cymodocea angustata, $\mathrm{Hu}=$ Halodule uninervis, $\mathrm{Ho}=$ Halophila ovalis, $\mathrm{Hs}=$ Halophila spinulosa, $\mathrm{Pa}=$ Posidonia australis. 


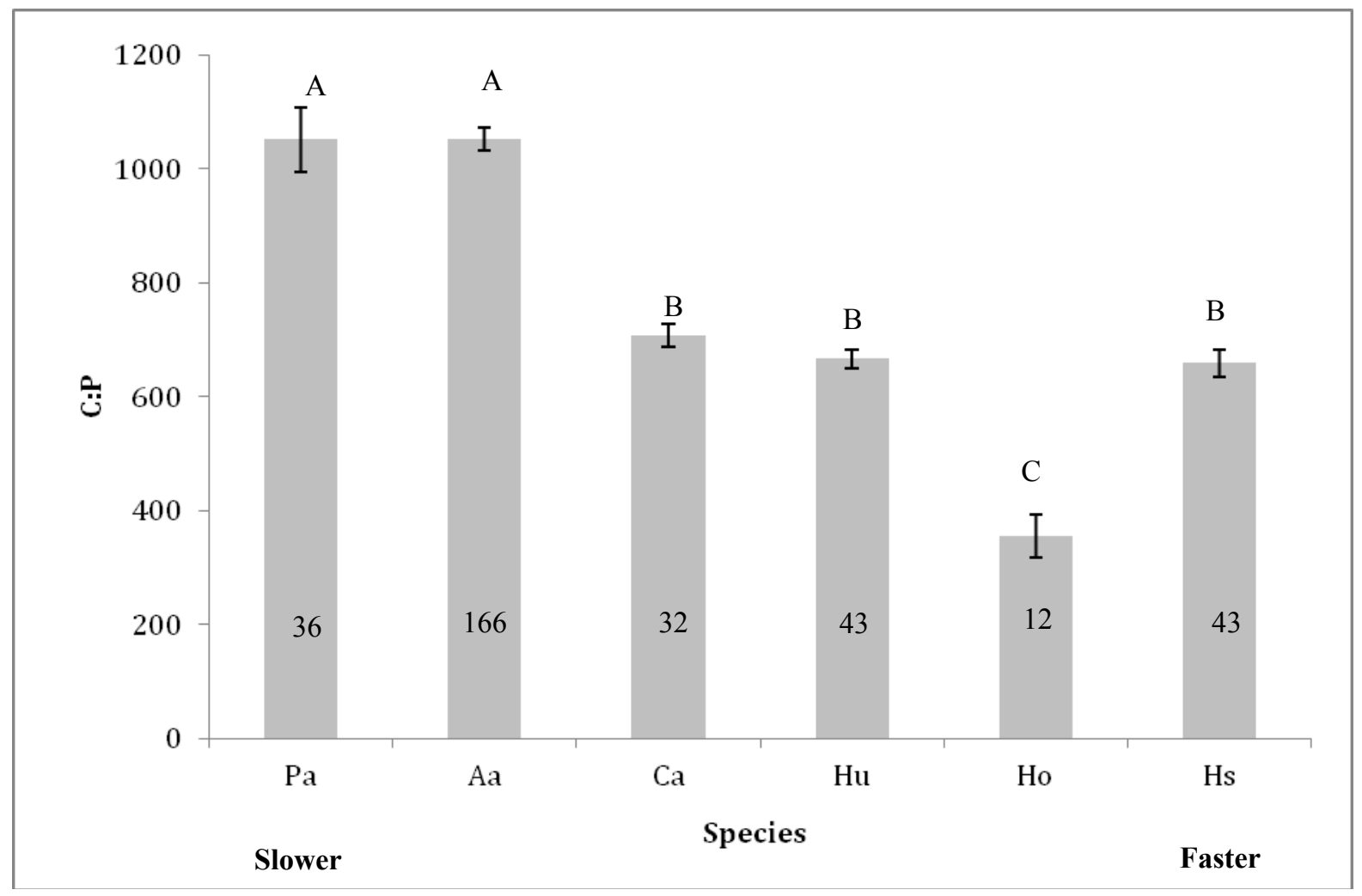

Figure 1b: Interspecific variation in C:P ratios of seagrasses collected for feeding preference trials. Error bars are $+/-$ SE. Bars labeled with the same letter are not statistically different from one another. Note, that lower values should indicate species of greater quality from an herbivores perspective (i.e. higher relative $\mathrm{N}$ or $\mathrm{P}$ content). Seagrass species are arranged along the $\mathrm{X}$-axis based on leaf turnover rates from slowest to fastest. $\mathrm{Aa}=$ Amphibolis antarctica, $\mathrm{Ca}=$ Cymodocea angustata, $\mathrm{Hu}=$ Halodule uninervis, $\mathrm{Ho}=$ Halophila ovalis, $\mathrm{Hs}=$ Halophila spinulosa, $\mathrm{Pa}=$ Posidonia australis . 


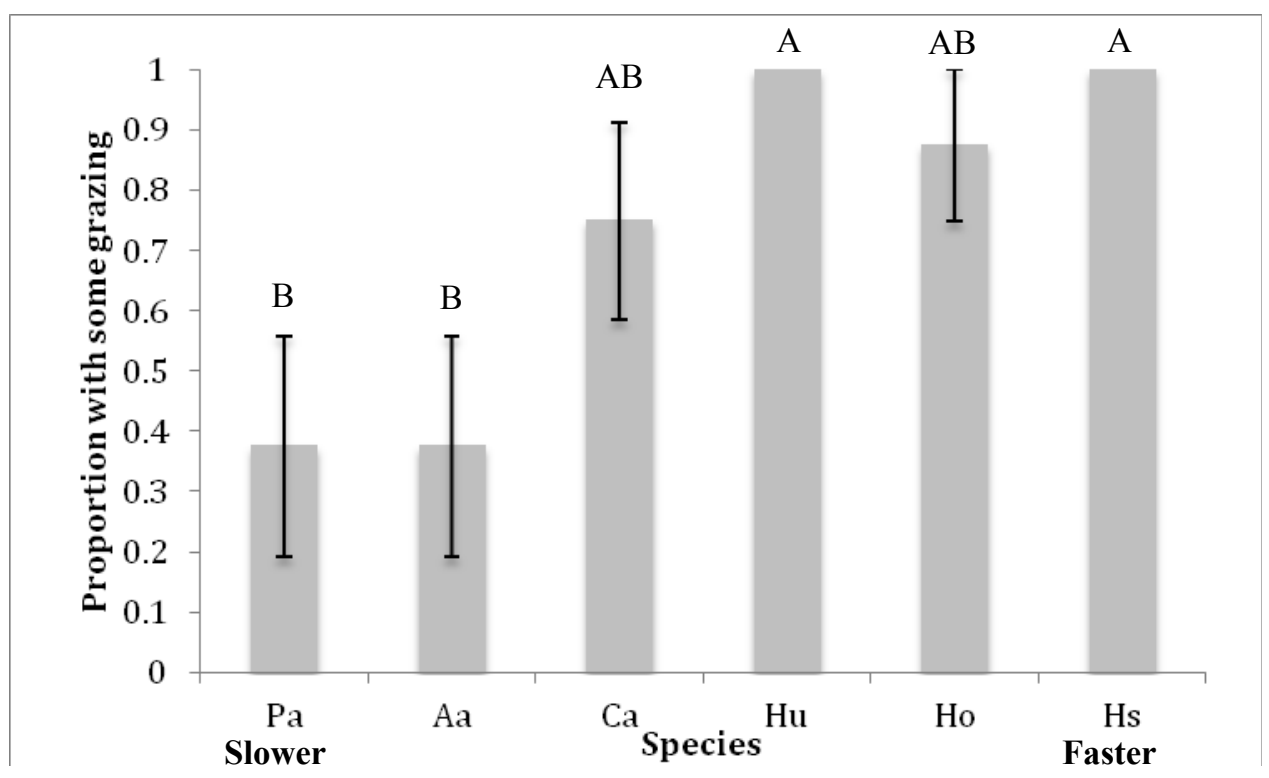

Figure 2a: Proportion of lines with at least some grazing on seagrasses during 2007 trials in interior microhabitats. Bars with the same letter are not significantly different. Error bars are +/- SE. Seagrass species are arranged along the X-axis based on leaf turnover rates from slowest to fastest. $\mathrm{Aa}=$ Amphibolis antarctica, $\mathrm{Ca}=$ Cymodocea angustata, $\mathrm{Hu}=$ Halodule uninervis, $\mathrm{Ho}=$ Halophila ovalis, $\mathrm{Hs}=$ Halophila spinulosa, $\mathrm{Pa}=$ Posidonia australis 


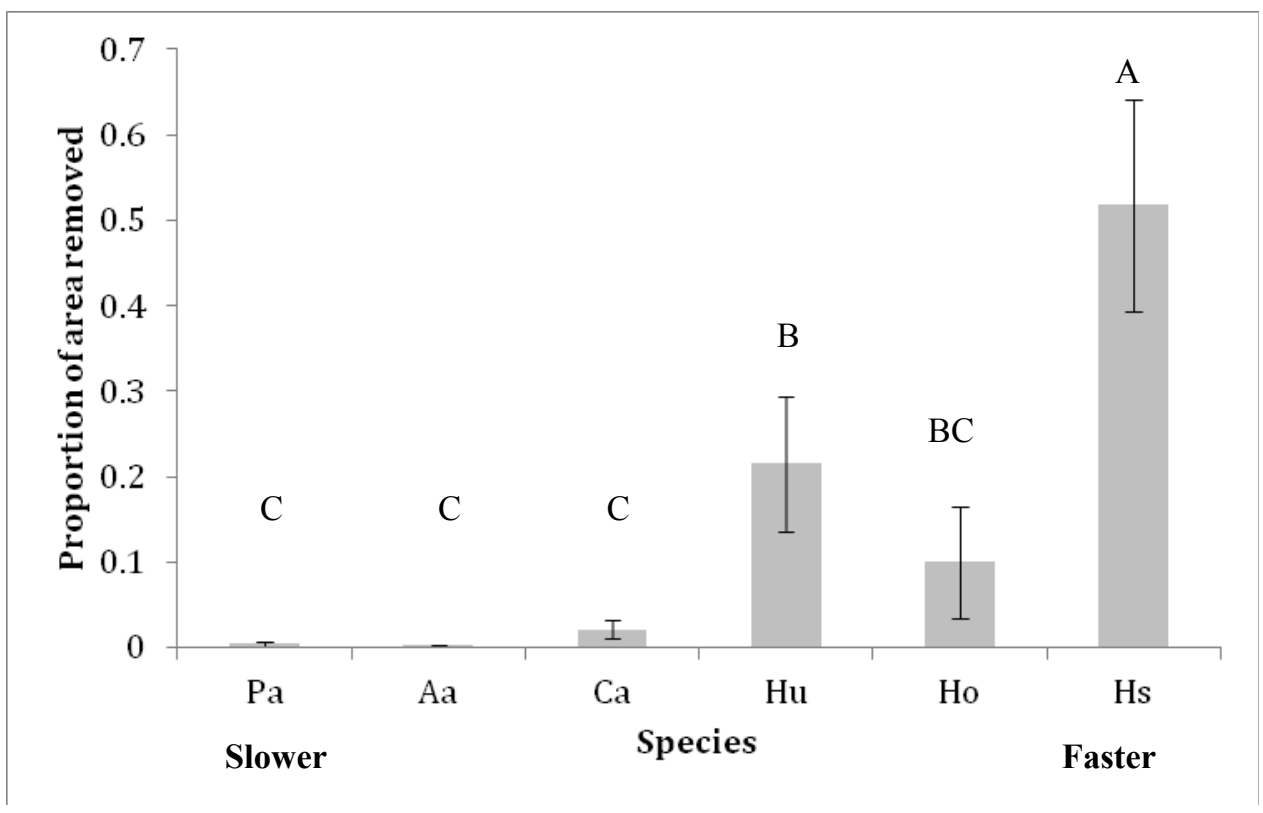

Figure 2b: Proportion of leaf area removed for lines and species that experienced at least some grazing of at least one serving. Bars with the same letter are not significantly different. Error bars are $+/-$ SE. Seagrass species are arranged along the $\mathrm{X}$-axis based on leaf turnover rates from slowest to fastest. $\mathrm{Aa}=$ Amphibolis antarctica, $\mathrm{Ca}=$ Cymodocea angustata, $\mathrm{Hu}=$ Halodule uninervis, $\mathrm{Ho}=$ Halophila ovalis, $\mathrm{Hs}=$ Halophila spinulosa , $\mathrm{Pa}=$ Posidonia australis 


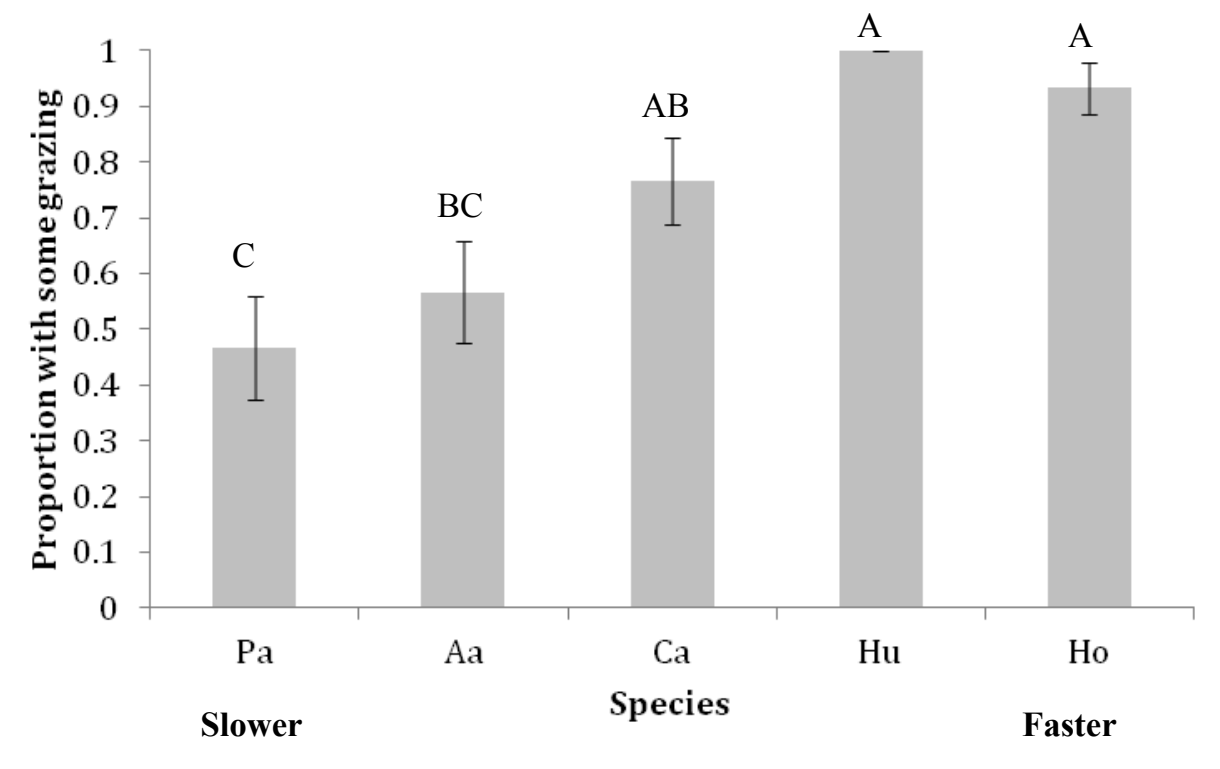

Figure 3a: Proportion of lines with at least some grazing on seagrasses during 2009 trials in interior, edge and deep microhabitats. There was no detectable effect of habitat or the interaction of habitat and species. Bars with the same letter are not significantly different. Error bars are $+/-$ SE. Seagrass species are arranged along the $\mathrm{X}$-axis based on leaf turnover rates from slowest to fastest. $\mathrm{Aa}=$ Amphibolis antarctica, $\mathrm{Ca}=$ Cymodocea angustata, $\mathrm{Hu}=$ Halodule uninervis, $\mathrm{Ho}=$ Halophila ovalis, $\mathrm{Hs}=$ Halophila spinulosa, $\mathrm{Pa}=$ Posidonia australis 


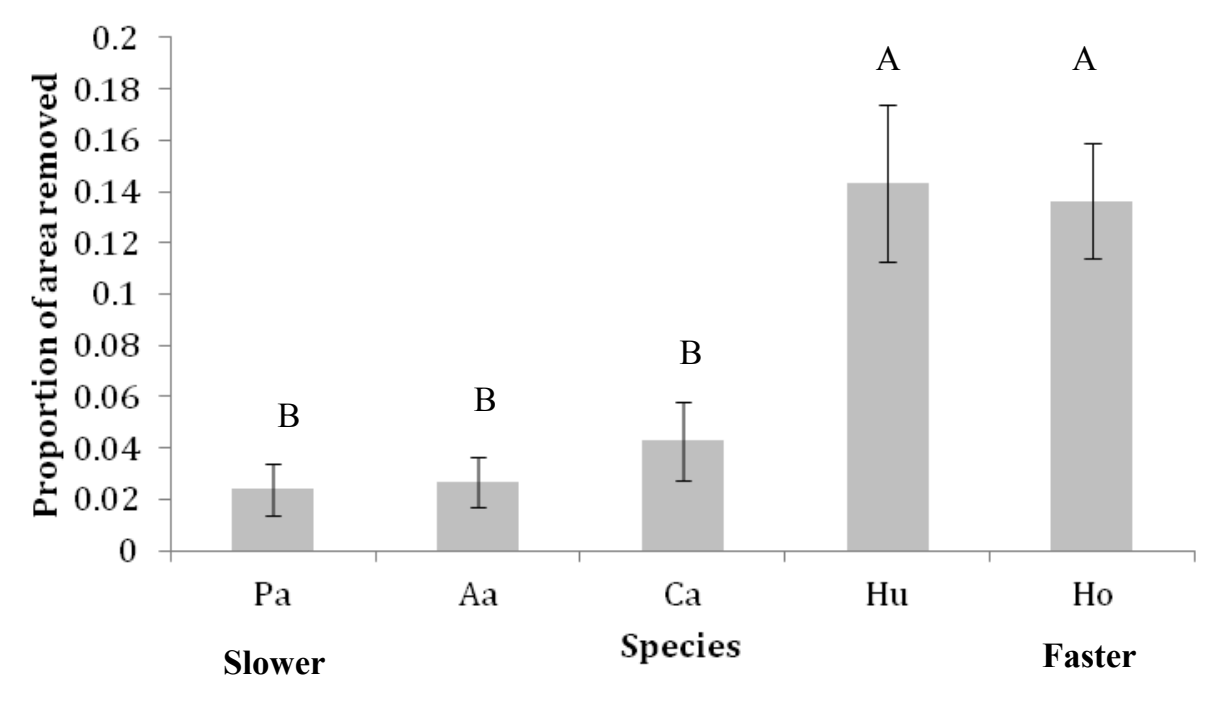

Figure 3b: Proportion of leaf area removed for lines and species that experienced at least some grazing of at least one serving. There was no detectable effect of habitat or the interaction of habitat and species. Bars with the same letter are not significantly different. Error bars are $+/$ - SE. Seagrass species are arranged along the $\mathrm{X}$-axis based on leaf turnover rates from slowest to fastest. $\mathrm{Aa}=$ Amphibolis antarctica, $\mathrm{Ca}=$ Cymodocea angustata, $\mathrm{Hu}=$ Halodule uninervis, $\mathrm{Ho}=$ Halophila ovalis, $\mathrm{Hs}=$ Halophila spinulosa, $\mathrm{Pa}=$ Posidonia australis. 
CHAPTER IV

DIVERSITY IN TROPHIC INTERACTIONS OF GREEN SEA TURTLES

CHELONIA MYDAS ON A RELATIVELY PRISTINE COASTAL

FORAGING GROUND 


\begin{abstract}
Adult green sea turtles Chelonia mydas are often the largest-bodied herbivores in their communities and may play an important role in structuring seagrass and macroalgal communities. Recent studies, however, suggest that green turtles might be more omnivorous than previously thought. I used animal-borne videography and nitrogen and carbon stable isotopic analysis of skin to elucidate diets of green turtles in the relatively pristine seagrass ecosystem of Shark Bay, Australia. Stable isotope values suggested that despite the presence of abundant seagrass resources, turtles assimilated most of their energy from a combination of macroalgae and gelatinous macroplankton (cnidarians and ctenophores). Video data suggested that macroplankton might be the most commonly consumed food source. Also surprising was the considerable variation in $\mathrm{d}^{13} \mathrm{C}$ values, suggesting long-term dietary specialization by individual turtles. Overall, green turtle foraging under natural conditions may be less stereotyped than previously thought, and diets of green turtles inhabiting apparently similar ecosystems (e.g., seagrass-dominated ecosystems) may vary considerably across geographical regions. The apparently high degree of individual specialization in diets suggests that conservation efforts should account not only for the potential importance of non-benthic food sources for green turtle populations, but also for the possibility that subsets of the population may play different ecological roles and may be differentially vulnerable to anthropogenic impacts.
\end{abstract}




\section{INTRODUCTION}

Large herbivores, including green sea turtles Chelonia mydas and sirenians, can structure seagrass communities by changing species composition and biomass or shortcircuiting detrital cycles (e.g., Thayer \& Engel 1982, Bjorndal 1997, Aragones \& Marsh 2000, Moran \& Bjorndal 2005, Aragones et al. 2006). For example, green turtles considerably shorten the decomposition time of some seagrass species (e.g. Thalassia testudinum; Thayer \& Engel 1982), and nitrogen-rich feces matter may stimulate the production of seagrasses, many of which are nitrogen-limited (Thayer \& Engel 1982, Carruthers et al. 2002). Turtle grazing also may increase seagrass forage quality by promoting the growth of new leaves, which have higher nutrient content and lower lignin content and are digested more easily than old leaves (Bjorndal 1980). Intense herbivory by green turtles may cause shifts in seagrass community structure (Kuiper-Linley et al. 2007, Wabnitz et al. 2010) or even result in declines in the biomass present in seagrass communities (Murdoch et al. 2007, Fourqurean et al. 2010). Excluding green turtles from a T. testudinim-dominated seagrass meadow in Bermuda for $1 \mathrm{yr}$ resulted in an increase in seagrass biomass and structural complexity of the seagrass canopy when compared to grazed sites (Fourqurean et al. 2010). Understanding the reliance on seagrasses and other resources for food and how the use of these resources might vary within and among populations is of key importance in estimating the ecological impact of green turtles.

Green turtles are traditionally thought to undergo abrupt ontogenetic shifts in their diets, from carnivory during the pelagic phase of their lives to nearly complete herbivory once they settle in coastal habitats at a curved carapace length (CCL) of 40-44 cm 
(Chaloupka \& Limpus 2001, Arthur et al. 2008). Neritic green turtle diets have been investigated primarily by comparing available food sources to forage found in mouth contents, lavage samples, stomach contents of dead animals, or fecal matter (e.g., Mortimer 1981, Brand et al. 1999, Seminoff et al. 2002, Arthur et al. 2009). These studies suggest that the diets of neritic-stage green turtles are made up almost exclusively of seagrasses and algae, with actual diet composition driven by the relative availability and quality of these food types (e.g., Bjorndal 1980, Forbes 1994, Brand-Gardner et al. 1999, Read \& Limpus 2002). For example, stomach content analysis of 243 green turtles in Nicaragua showed that a seagrass-dominated diet with Thalassia testudinum accounted for almost $90 \%$ of diets in the northern part of the study while algae was much more prevalent (up to $63 \%$ of diets) in the southern region (Mortimer 1981). In algaldominated communities of the Gulf of California, Mexico, green turtle diets are comprised of a diverse assemblage of marine algaes, with red algaes accounting for around $90 \%$ of the diet (Seminoff et al. 2002). Likewise, the diets of neritic green turtles in Moreton Bay, south-eastern Queensland, were dominated by a mixture of seagrass and algae. Analysis of digesta boluses throughout the digestive tract, which represent different feeding bouts, suggest that turtles change diets between seagrass and algae, sometimes abruptly (Brand et al. 1999). Traditional diet analysis techniques are advantageous because food items can be identified and quantified; however, they are not without limitations. For example, animals often have empty stomachs, and gut content analysis only provides a snapshot of what has been eaten recently. Also, the snapshot may be biased by variation in digestibility among prey items with harder items remaining 
in guts for longer periods than soft-bodied organisms that may become unidentifiable in a very short time (Hyslop 1980).

Stable isotopic analysis has become a widespread tool in ecology that can be used to infer trophic interactions and supplement insights obtained from traditional diet analysis (e.g., Hooker et al. 2001, Post 2002, Felicetti et al. 2003). It is possible to use carbon isotopic values to determine the relative contribution of different primary producers to a consumer's diet because primary producers (e.g., plankton, seagrass, and algae) incorporate ${ }^{12} \mathrm{C}$ and ${ }^{13} \mathrm{C}$ into their tissues at different rates, and carbon isotopes exhibit relatively low rates of fractionation with each trophic transfer (Peterson \& Fry 1987, Hobson \& Clark 1992). Relative trophic level can be determined using the ratio of ${ }^{15} \mathrm{~N}:{ }^{14} \mathrm{~N}$ because of trophic enrichment of ${ }^{15} \mathrm{~N}$ in a consumer's tissues relative to that of its prey (DeNiro \& Epstein 1981, Minagawa \& Wada 1984). Stable isotopic values, however, may be hard to interpret in the absence of other techniques (e.g., stomach contents, direct observations) for assessing trophic interactions because isotopic values represent average diets and different diet combinations may lead to similar isotopic values in a consumer (Bolnick et al. 2003).

Both stable isotopes and diet analysis as well as behavioral studies have revealed that there can be considerable and consistent variation in behaviors and diets among individuals of a population, including those of the same age/sex class (e.g. Estes et al. 2003, Bearhop et al. 2004, Svanback \& Bolnick 2005, 2007, Vander Zanden et al. 2010, Matich et al. 2011; see Bolnick et al. 2003 for a review). Understanding patterns and factors driving this 'individual specialization,' in which groups of individuals specialize on a subset of resources used by the population as a whole, is important because it can 
play an important role in population, community, and evolutionary dynamics and may impact conservation planning (Baird et al. 1992, Bolnick et al. 2003, Araújo et al. 2009, Newsome et al. 2009, Hammerschlag-Peyer \& Layman 2010). In general, individual specialization should be more likely if (1) resources are scarce, (2) individuals can only forage efficiently on a subset of resources, (3) cognitive constraints limit the use of diverse sets of resources, (4) foraging specializations are transmitted culturally, (5) different habitats have different resource pools and individuals only inhabit a subset of habitats, or (6) ecological trade-offs result in variation among individuals in resource pools that are accessed (Rendell \& Whitehead 2001, Estes et al. 2003, Svanback \& Persson 2004, Araújo \& Gonzaga 2007, Darimont et al. 2009, Matich et al. 2011, Rosenblatt \& Heithaus 2011).

An increased awareness of patterns of individual specialization has, in part, been facilitated by stable isotopic techniques that can provide a long-term record of foraging. Indeed, patterns of specialization within populations can be estimated by comparing variation in isotopic values within and among individuals using either tissues that leave a serial record of foraging (turtle scutes, Vander Zanden et al. 2010; hooves, Harrison et al. 2007; whiskers, Newsome et al. 2009) or multiple tissues with different turnover rates that provide evidence of short- and long-term variation in diets within individuals and populations (e.g., Matich et al. 2011). In the absence of these data, assessing the degree of among-individual variation in isotopic values in tissues with long turnover times can provide insights into patterns of specialization because individuals with similar diets should converge on a similar isotopic value. Recent studies using isotopic approaches have raised the possibility of individual specialization in large-bodied marine taxa (e.g., 
sea otters, Newsome et al. 2009; bull sharks, Matich et al. 2011; American alligators, Rosenblatt \& Heithaus 2011) including loggerhead turtles Caretta caretta (Vander Zanden et al. 2010). However, how widespread individual specialization might be in large-bodied marine taxa, especially potential herbivores like green turtles, remains unclear.

Recent studies have suggested that patterns of green turtle foraging may be more complex than previously thought, and in locations outside of the Caribbean basin, turtles may exhibit omnivory. For example, animal-borne imaging results suggest that green turtles in Western Australia (Heithaus et al. 2002a) and Queensland (Arthur et al. 2007) may consume significant numbers of gelatinous macroplankton (jellyfish or ctenophores). Similarly, green turtles in the Gulf of California, Mexico, have been recorded consuming 5 invertebrate species, in addition to marine algae (there is no seagrass in these habitats) (Seminoff et al. 2006a). Stable isotopic values of scutes from green turtles off the NW African coast suggest that the transition from omnivory to herbivory may be less abrupt than previously documented (Reich et al. 2007), with turtles in some regions continuing to consume animal matter - especially discarded fish from local fisherman - well after settling into coastal habitats (Cardona et al. 2009). These studies highlight the need to employ multiple techniques to accurately assess the diet of marine turtles, including those that can overcome the issues of differential digestibility which are likely for turtles that may consume seagrass and soft-bodied prey like ctenophores and cnidarians. They also suggest that green turtles may play more varied ecological roles than generally appreciated and that populations may forage on diverse resource pools, which could result in individual specialization (e.g., Vander Zanden et al. 2010). 
Most studies of green turtle foraging have occurred in areas where turtle populations have undergone drastic declines (Caribbean and Mexico) (Jackson 1997, Jackson et al. 2001). Therefore, studies of the ecological role of turtle diets in relatively pristine areas are a priority for predicting the dynamics of turtle populations and their ecosystems as turtle populations begin to rebound (Hamann et al. 2010). The objective of the present study was to investigate the foraging ecology of green turtles in a relatively pristine seagrass ecosystem. Specifically, I (1) assessed the relative importance of seagrass, macroalgae, and gelatinous macroplankton in the diets of green turtles using stable isotopic analysis, gastric lavage, and animal-borne imaging; (2) investigated variation in diets among turtle sizes and capture location (nearshore vs. offshore seagrass beds) using stable isotopic analysis; and (3) used stable isotopic signatures to gain insights into the potential for individual specialization in foraging.

\section{Materials and Methods}

Study site

The study was conducted in the eastern gulf of Shark Bay, Western Australia $\left(\sim 25^{\circ} 45^{\prime} \mathrm{S}, 113^{\circ} 44^{\prime}\right.$ E; Fig. 1). Located about $800 \mathrm{~km}$ north of Perth, Shark Bay is a shallow $(<15 \mathrm{~m})$ subtropical bay dominated by extensive seagrass beds, which cover approx. $4000 \mathrm{~km}^{2}$ (Walker et al. 1988). My study site in the Eastern Gulf is characterized by a series of shallow $(<4.5 \mathrm{~m})$ seagrass banks, separated by deeper channels $(6-11 \mathrm{~m})$ mostly covered by sand.

Listed as a World Heritage Area in 1991, Shark Bay is perhaps one of the most pristine remaining seagrass ecosystems in the world and affords a unique opportunity to 
examine the effects of large herbivores on seagrass ecosystems (Heithaus et al. 2007). Turtle populations in Shark Bay are large and exhibit characteristics of populations near carrying capacity (Heithaus et al. 2005). The seagrass community is a diverse assemblage of temperate and tropical seagrass species. The dominant species in the bay are temperate species, including Amphibolis antartica, Posidonia australis, and P. coriacea. Smaller, faster-growing tropical seagrass species, including Halophila ovalis, H. spinulosa, Halodule uninervis, Cymodocea angustata, Syringodium isoetifolium, Halophila decipiens and H. minor (Walker et al. 1988), are found in lower abundances. Other potential food sources for turtles include several macroalgae species found throughout the study area (D. Burkholder pers. obs.) as well as ctenophores and jellyfish (Heithaus et al. 2002a). Macroalgae are found in relatively low abundance in both deep and shallow habitats (up to 34 and $26 \%$ of the mean above ground biomass of $A$. antarctica and $P$. australia beds, respectively; Walker \& McComb 1988) biomass is very low in beds of tropical species and in areas lacking seagrasses (D. Burkholder pers. obs.). Macroalgae are found primarily growing on large pieces of shell or as epiphytes on A. antarctica in the shallows, or on rare patches of hard bottom exposed in the deeper channels (D. Burkholder pers. obs.). The most common species in shallow habitats are the brown algae Sargassum sp., Padina sp., and Dictyota sp. The red alga Spyridia sp., Laurencia sp., and the green alga Penicillus sp. can be found in the shallows in low densities. Sargassum sp. is the most common species found in deeper waters (D. Burkholder pers. obs.). 


\section{Field methods}

From 2006-2009, skin tissue was collected from 65 green turtles to assess stable isotopic values (Fig. 2). Turtles were captured throughout each year using the 'rodeo' technique (Ehrhart \& Ogren 1999, Heithaus et al. 2002b, 2005) in which they were encountered during haphazard searches (targeting for turtle capture for this or other studies) of the study area or during standardized transects run weekly (weather permitting). Sampling took place throughout the year as part of long-term studies of the abundance and habitat use of turtles and other air-breathing taxa, and the majority of samples are from 2006 and 2007. Captured turtles were brought on board the research vessel and tagged with titanium flipper tags (Department of Environment and Conservation, Western Australia). I measured CCL and tail length (tip of tail to carapace). A small skin tissue sample $(3 \times 1 \times 1 \mathrm{~cm})$ was collected with scissors from the trailing edge of the foreflipper. The sample location was chosen to minimize turtle stress. Tissue samples were immediately placed in ice and then stored at $-20^{\circ} \mathrm{C}$ until processing. Turtle captures were categorized into 2 locations: (1) nearshore shallow $(<3 \mathrm{~m})$ habitat dominated by a sand and seagrass bank extending up to $\sim 2 \mathrm{~km}$ from shore (nearshore); and (2) a series of narrow ( $3 \mathrm{~km}$ long $\times 0.5 \mathrm{~km}$ wide), shallow offshore seagrass banks separated by deeper ( $\sim 10 \mathrm{~m})$ mostly sand bottom channels (offshore) (Fig. 1).

During June and July 2006 I conducted gastric lavage (Forbes \& Limpus 1993) on 3 green turtles. Briefly, turtles were brought onboard the research vessel, inverted, and water was gently pumped into the stomach to flush stomach contents into a sieve. Contents were collected, stored immediately on ice in the field and then stored at $-20^{\circ} \mathrm{C}$ until processing. For analysis, stomach contents were thawed and sorted to the lowest 
possible taxon under a dissecting microscope. Wet weights were then calculated for each discernible food group. In addition, the stomach contents of one dead green turtle were examined.

Samples of primary producers and primary consumers were collected during stratified benthic sampling of the study site or by haphazard collections when new species were encountered to establish the stable carbon and nitrogen isotopic composition of potential food for green turtles. Primary producers were collected during 2006-2009 from randomly generated point-sampling sites in three habitat/microhabitats (deep, middle of shallow seagrass beds, edge of seagrass beds) as part of a larger study of seagrass community composition and nutrient dynamics (Wirsing et al. 2007, Burkholder et al. in press). Samples were collected either snorkeling or on SCUBA, and sites were sampled both in the summer and winter to describe seasonal variation in isotopic values. Gelatinous macroplankton (cnidarians and ctenophores) were collected using a $200 \mathrm{~mm}$ neuston net towed slowly behind my vessel or were collected by hand for larger individuals. Collections were stored on ice and then frozen at $-20^{\circ} \mathrm{C}$ until processing. I collected samples from isopods and a dugong (Dugong dugon) to compare green turtle isotopic values to those of species known to consume primarily seagrasses (i.e., to determine isotopic values that would be expected for green turtles foraging primarily on seagrasses). Isopods were collected using a fine-mesh dip net pushed through seagrass beds. The net contents were sorted and stored on ice for processing. I obtained a lone sample of dugong skin from a recently deceased individual that was stored on ice in the field and frozen at $-20^{\circ} \mathrm{C}$ until processing. 
Animal-borne video and environmental data collection systems (AVED; National Geographic's 'Crittercam') were deployed on 17 green turtles from 1999-2003 to monitor foraging behavior of green turtles. The AVED unit, which consisted of a Hi-8 video camera and time-depth recorder inside an aluminum housing $(10.1 \mathrm{~cm}$ diameter, $31.7 \mathrm{~cm}$ in length) that was fitted with a VHF transmitter, was attached to the turtle by securing a plexiglass baseplate using cool-setting epoxy (Ten-Set $\left.{ }^{\mathrm{TM}}\right)$ to the carapace and then attaching the camera to this plate using a wire and magnesium washer. The camera was positioned so that the head was in view and programmed to release from the turtle after 3-24 h by a burnwire mechanism or a dissolving magnesium washer (see Heithaus et al. 2002a for further details).

\section{Laboratory methods and analysis}

Turtle and dugong tissue collected for isotopic analysis was rinsed in deionized (DI) water, cleaned of epiphytes, dried in a food dehydrator (Ezidri Ultra FD1000) for at least $24 \mathrm{~h}$ and then ground to a fine powder. Because of the small amount of tissue in a single dehydrated ctenophore or jellyfish, 10-20 individuals (depending on size) collected from the same tow or sample area were combined to form a single sample of gelatinous macroplankton for analysis. For these taxa, samples were dehydrated immediately after returning from the field and then powdered. Isopods were dried as whole individuals and ground to a fine powder. For all plant material, a razor blade was used to scrape epiphyte/epibiota from leaves and stems prior to dehydration and isotopic values of epibiota were analyzed separately. Leaf material was separated from stem material (in Amphibolis sp.) or from root and rhizome material (for all other seagrass 
species), and tissues were analyzed separately. At least 5 plants were collected for each species of seagrass at each sampling point, and a subsample of each of those 5 plants was combined to form a single sample for that time/site. For seagrass, algae, and isopods I analyzed carbon isotopic signatures both with and without acidification procedures. If acidification resulted in changes in carbon isotopic values of more than $0.3 \%$ then acidified $\mathrm{d}^{13} \mathrm{C}$ values were used. Acidification involved spreading a thin layer of powder in a glass petri dish and placing it in a sealed chamber that contained an open container of hydrochloric acid for at least $24 \mathrm{~h}$. The tissue was then dehydrated and powdered. Lipid extraction was not performed on any samples because the $\mathrm{C}: \mathrm{N}$ ratios indicated that lipid corrections were not necessary (i.e., C:N < 3.5, as in Post et al. (2007); C:N flipper tissue $=3.0 \pm 0.2 \mathrm{SD}$ ). Likewise most of the $\mathrm{C}: \mathrm{N}$ ratios of the prey individuals indicated that lipid extraction or correction was not necessary, and for the small number of samples with $\mathrm{C}: \mathrm{N}>3.5$, I corrected $\mathrm{d}^{15} \mathrm{~N}$ values according to equations in Post et al. (2007).

For analysis, $0.95-1.05 \mathrm{mg}$ for animal samples, $3.95-4.05 \mathrm{mg}$ for plant and algae samples, and 9-11 mg for ctenophore/cnidarian samples were weighed into tin capsules and analyzed for carbon and nitrogen isotope ratios at either University of Western Australia's Western Australia Biogeochemistry Center or Yale University's Earth System Center for Stable Isotopic Studies.

Analysis of stable isotopic values

I tested the effects of turtle size and location (nearshore vs. offshore seagrass banks) on $\mathrm{d}^{13} \mathrm{C}$ and $\mathrm{d}^{15} \mathrm{~N}$ signatures using general linear models. To investigate the size of the isotopic trophic niche of green turtles in Shark Bay relative to other consumers in 
Shark Bay, I calculated Layman et al.'s (2007) total area (TA) metric using the Animal Movement extension in ArcView 3.2. The total area metric provides a way to quantify the isotopic trophic diversity within a species and is calculated as the area of the minimum convex polygon that encompasses all individuals. I performed rarefaction analysis to determine if my sample size adequately captured the total isotopic area occupied by green turtles. I considered the sample size to be adequate if a regression through the final 4 points of the rarefaction curve failed to display a slope significantly different from 0 (Bizzarro et al. 2007). Because previous studies have suggested ontogenic changes in the diets/tissue isotope values of green turtles when they reach a CCL of $60 \mathrm{~cm}$, I conducted analyses of TA separately for all turtles and for turtles over $60 \mathrm{~cm}$ CCL (Cardona et al. 2009, 2010).

I used MixSir, a Bayesian-mixing model that accounts for variation in isotopic discrimination and source values (Moore \& Semmens 2008), to estimate the relative contributions of algae, seagrasses, and gelatinous macroplankton to the diets of green turtles in Shark Bay. These potential food sources were chosen on the basis of studies of green turtle diets in other parts of Australia as well as video data collected from green turtles in the study area. I assumed only a single trophic transfer (direct consumption of prey items by turtles) between these resource pools and turtles. I conducted analyses separately for turtles $<60 \mathrm{~cm} \mathrm{CCL}$ and $\geq 60 \mathrm{~cm} \mathrm{CCL}$. In addition, because of seasonal differences in the isotopic signatures of potential food sources, I conducted separate analyses for winter (June to August) and summer (September to May) for turtles $\geq$ $60 \mathrm{~cm} \mathrm{CCL}$ (sample sizes were not adequate for seasonal analysis of turtles $<60 \mathrm{~cm}$ ). Because discrimination factors are not known for neritic green turtles, I conducted 
MixSir modeling using 3 different estimates of discrimination factors that together should provide robust insights into trophic interactions of turtles. First, I used ${ }^{13} \mathrm{C}$ and ${ }^{15} \mathrm{~N}$ discrimination factors measured in juvenile green turtles Chelonia mydas fed on a carnivorous diet (Seminoff et al. 2006b; skin tissue: ${ }^{15} \mathrm{~N} 2.80 \pm 0.11 \%,{ }^{13} \mathrm{C} 0.17 \pm$ $0.03 \%$ ). Second, because green turtles are thought to be primarily herbivorous and use hind-gut fermentation, which can result in substantially different discrimination factors I used ${ }^{13} \mathrm{C}$ and ${ }^{15} \mathrm{~N}$ discrimination factors measured in Florida manatees Trichechus manatus latirostris, a large-bodied marine hind-gut fermenting herbivore (Alves-Stanley \& Worthy 2009; skin tissue ${ }^{15} \mathrm{~N}$ [estimated] $5.0 \pm 0.00 \%,{ }^{13} \mathrm{C} 2.80 \pm 0.09 \%$ ). Finally, I used average ${ }^{13} \mathrm{C}$ and ${ }^{15} \mathrm{~N}$ discrimination factors based on meta-analysis of isotopic studies by Caut et al. (2009) $\left({ }^{15} \mathrm{~N} 2.75 \pm 0.1 \%\right.$; $\mathrm{d}^{13} \mathrm{C} 0.75 \pm 0.11 \%$ ). I used 25000000 iterations for each season, and size grouping. I conducted 5000000 iterations to explore the mix of food resources used by individual turtles exhibiting peripheral stable isotopic values of the population's TA.

Because green turtles consume seagrass and its epiphytes simultaneously, I conducted a second set of all MixSir models described above using a combined 'seagrass + epiphytes' resource pool. Since I do not have data on the relative biomass of epiphytes and seagrass in my samples, I combined means and standard deviations using the maximum proportion of epiphytes to seagrass tissue for Amphibolis griffithii (50\% of total aboveground biomass, Borowitzka et al. 1990; estimates for species in my study area were not available). By combining means and standard deviations it should provide an upper estimate of the contribution of the seagrass/epiphyte resource pool to green 
turtle diets (under the assumptions of the mixing model) since epiphytes have $\mathrm{d}^{13} \mathrm{C}$ values that are slightly more negative than those of seagrass (see 'Results').

\section{Video analysis}

Video footage was analyzed for foraging behavior and foraging rates of green turtles. In many cases, food items (especially seagrasses and macroalgaes) could be identified as the turtle approached and fed. Foraging on gelatinous macroplankton was primarily observed while travelling midwater, and although it was possible to see prey being captured in many cases, sometimes foraging was inferred from turtle head movements identical to those when prey capture was observed followed by neck movements consistent with swallowing (Heithaus et al. 2002a). I quantified the number of ctenophores and jellyfish consumed as well as the number of bites of green turtles displayed relatively unique isotopic signatures. Tropical seagrass species (Halophila ovalis, H. spinulosa, Halodule uninervis, Cymodocea angustata, Syringodium isoetifolium) had $\mathrm{d}^{13} \mathrm{C}$ values between -4.6 and $-12.2 \%$ while temperate seagrass species Amphibolis antarctica and Posidonia australis showed lower $\mathrm{d}^{13} \mathrm{C}(-8.0$ to $-13.3 \%$ ), and seagrass epibiota varied from -8.2 to $-15.2 \%$ (Fig. 3). Macroalgae had lower $\mathrm{d}^{13} \mathrm{C}$ values than seagrass and ranged between $-12.0 \%$ and $-24.1 \%$. The range of $\mathrm{d}^{13} \mathrm{C}$ of gelatinous macroplankton $(-15.1$ to $-19.8 \%$ ) was similar to that of macroalgae, suggesting that planktonic microalgae are similar in $\mathrm{d}^{13} \mathrm{C}$ to macroalgae. The $\mathrm{d}^{13} \mathrm{C}$ of Sargassum sp. ranged from -12.04 to $-16.89($ mean $=-14.15 \pm 1.46 \%$ SE), Padina $\mathrm{sp}$. ranged from 14.20 to $-17.88($ mean $=-16.66 \pm 1.16 \%$ SE), Dictyota sp. ranged from -13.28 to -16.40 
$($ mean $=-15.16 \pm 1.10 \%$ SE), Laurencia sp. ranged from -20.11 to $-24.05($ mean $=-$ $22.31 \pm 2.06 \%$ SE), and Penicillus sp. ranged from -13.74 to -15.24 (mean $=-14.31 \pm$ $0.80 \%$ o $\mathrm{SE}$ ). There was significant seasonal variation in $\mathrm{d}^{13} \mathrm{C}$ of gelatinous macroplankton ( $\mathrm{n}=10$ in summer, $\mathrm{n}=7$ in winter, $F_{1,15}=45.2, \mathrm{p}<0.001$ ) with lower $\mathrm{d}^{13} \mathrm{C}$ in winter $($ mean $=-19.7 \pm 0.2 \% \mathrm{SE})$ than summer $($ mean $=-17.9 \pm 0.2 \% \mathrm{SE})$. The $\mathrm{d}^{15} \mathrm{~N}$ values of gelatinous macroplankton also varied seasonally $\left(F_{1,15}=8.1, \mathrm{p}=0.01\right)$ with higher $\mathrm{d}^{15} \mathrm{~N}$ in winter $($ mean $=7.6 \pm 0.2 \% \mathrm{SE})$ than summer $($ mean $=6.8 \pm 0.2 \% \mathrm{SE})$. Importantly for my mixing models, the $\mathrm{d}^{15} \mathrm{~N}$ values of macroalgae (range $=2.0-5.0 \%$ ) were lower than those of gelatinous macroplankton, but were higher than those of seagrasses, which ranged from -6.7 to $3.2 \%$ (Fig. 3). The $\mathrm{d}^{15} \mathrm{~N}$ of Sargassum sp. ranged from 2.48 to 4.86 $($ mean $=3.53 \pm 0.67 \%$ SE), Padina $\mathrm{sp}$. ranged from 2.04 to $5.03($ mean $=3.44 \%$ \pm 0.89\% SE), Dictyota sp. ranged from 2.27 to 4.98 (mean $=3.55 \pm 0.93 \%$ o SE), Laurencia sp. ranged from 3.86 to 4.48 (mean $=4.23 \pm 0.27 \%$ SE), and Penicillus sp. ranged from 3.75 to $3.88($ mean $=3.80 \%$ $\pm 0.07 \%$ o $\mathrm{SE})$. There was no significant seasonal variation in seagrass $($ A. antarctica $) \mathrm{d}^{13} \mathrm{C}\left(\mathrm{n}=33\right.$ in summer, $\mathrm{n}=17$ in winter, $\left.F_{1,48}=0.2, \mathrm{p}=0.66\right)$ or $\mathrm{d}^{15} \mathrm{~N}\left(F_{1,48}=2.0, \mathrm{p}=0.17\right)$. Macroalgae showed no seasonal variation in $\mathrm{d}^{13} \mathrm{C}(\mathrm{n}=22$ in summer, $\mathrm{n}=29$ in winter, $\left.F_{1,49}=0.0006, \mathrm{p}=0.98\right)$, but their $\mathrm{d}^{15} \mathrm{~N}$ was significantly higher in the summer $\left(\right.$ mean $=4.0 \pm 0.1 \%$ SE) than winter $($ mean $=3.3 \pm 0.1 \%$ SE $)\left(F_{1,49}\right.$ $=14.3, \mathrm{p}=0.0004)$.

Invertebrate grazers found on seagrasses (isopods) and a dugong, which is known to consume seagrass almost exclusively, had similar isotopic values. The $\mathrm{d}^{13} \mathrm{C}$ values were near $-10 \%$, which is similar to that of seagrass, while $\mathrm{d}^{15} \mathrm{~N}$ ranged between $4.7-$ 6.1\%o for isopods and a dugong (Fig. 3). 


\section{Results}

\section{Green turtle trophic relationships}

\section{Stable isotopes}

The $\mathrm{d}^{13} \mathrm{C}$ values of green turtles $(\mathrm{n}=65)$ ranged from -22.4 to $-9.8 \%$ o $($ mean $=-$ $15.0 \pm 3.0 \% \mathrm{SD})$ and $\mathrm{d}^{15} \mathrm{~N}$ ranged from 4.7 to $10.8 \%$ o $($ mean $=7.7 \%$ $\pm 1.1 \%$ o $\mathrm{SD})$ suggesting that turtles fed at more than one trophic level. There was no effect of CCL on $\mathrm{d}^{13} \mathrm{C}$ and $\mathrm{d}^{15} \mathrm{~N}\left(\mathrm{~d}^{13} \mathrm{C}: F_{1,63}=0.0001, \mathrm{p}=0.99 ; \mathrm{d}^{15} \mathrm{~N}: F_{1,63}=2.7, \mathrm{p}=0.11 ;\right.$ Fig. 4$)$ or between offshore banks and nearshore shallows $(n=23$ for nearshore, $n=32$ for offshore seagrass banks; $\left.\mathrm{d}^{13} \mathrm{C}: F_{1,53}=0.8, \mathrm{p}=0.38 ; \mathrm{d}^{15} \mathrm{~N}: F_{1,53}=2.8, \mathrm{p}=0.10\right)$.

The considerable variation in isotopic values of both $\mathrm{d}^{15} \mathrm{~N}$ and $\mathrm{d}^{13} \mathrm{C}$ resulted in large areas of isotopic niche space being occupied relative to other species in Shark Bay (see 'Discussion'). The isotopic values of all 65 turtles with flipper tissue samples

occupied 52.3 units $^{2}$ of area while the 57 turtles over $60 \mathrm{~cm} \mathrm{CCL} \mathrm{occupied} 42.4$ units $^{2}$ of area. Rarefaction analysis suggested that my sample of individuals adequately captured the total isotopic area occupied by green turtles for skin tissue $\left(F_{1,3}=2.5, \mathrm{p}=0.25\right)$.

On the basis of three estimates of isotopic discrimination (see 'Materials and methods') as well as the assumption that green turtles are limited to gelatinous macroplankton, macroalgae, and seagrasses in Shark Bay, green turtles overall assimilate strikingly little carbon from seagrasses (Table 1). Stable isotopes strongly suggest that green turtles of all size classes in Shark Bay are dependant mostly on macroalgae and gelatinous macroplankton. The median contribution of seagrasses to green turtles was always less than $10 \%$ regardless of discrimination assumptions. Even the 95 th percentile 
estimates suggested a $<16 \%$ contribution by seagrasses to green turtle diets. Adding epiphytes to the seagrass in the mixing model resulted in very little change in the estimated contribution of this complex to assimilated carbon. In comparison, running the MixSIR model for one single skin tissue sample from an obligate herbivore, the dugong in this study, using the discrimination factors for a close relative, the manatee, resulted in median estimates of $75 \%$ seagrass, $15 \%$ algae, and $8 \%$ gelatinous macroplankton contribution to the diet. The 8 turtles under $60 \mathrm{~cm}$ appear to have assimilated the large majority of their energy from macroalgae; fractionation assumptions had little effect on the estimated contribution of macroalgae with median contributions above $86 \%$ for all analyses (Table 1). Discrimination factor assumptions had much larger effects on predicted use of macroalgae vs. gelatinous macroplankton of turtles $>60 \mathrm{~cm}$. On the basis of analysis of skin tissue, median contributions were ca. $15-25 \%$ for gelatinous macroplankton and ca. $75-85 \%$ for macroalgae, based on discrimination assumptions for juvenile green turtles and average discrimination factors across taxa (Table 1). Manatee discrimination factors, however, greatly shifted predicted ratios, with macroalgae estimated to make up the vast majority of the assimilated diets and gelatinous macroplankton contributing virtually nothing to diets (Table 1). The MixSIR results suggested considerable individual variation in the relative mixes of algae, seagrasses, and ctenophores/cnidarians in the diets of individual green turtles (Table 2). Predicted resource use by individuals ranged from almost exclusive reliance on either gelatinous macroplankton or macroalgae to heavy reliance on seagrasses and most of the possible combinations in between (Fig. 3, Table 2). Even the manatee discrimination factors 
suggested that some individuals consumed considerable amounts of gelatinous macroplankton.

\section{Lavage}

Food items recovered from lavage supported the trends in diets suggested by stable isotopic analysis. Although the sample size was low $(\mathrm{n}=3)$, each individual had a considerable amount of food in its crop, but the compositions of the lavage contents were strikingly different. One sample contained only macerated seagrass (primarily Amphibolis antarctica) tissue (wet mass $=1.46 \mathrm{~g}$ ). A second lavage sample was primarily composed of fleshy red macroalgae Spongiophloea sp. (6.83 g; 98\% of total sample wet weight) with small contributions of the filamentous red algae Laurencia sp. $(0.1 \mathrm{~g} ; 1.4 \%$ of total sample wet weight) and macerated seagrass ( $0.4 \mathrm{~g}$ wet weight; $0.6 \%$ of total mass $)$. The third lavage sample was dominated by the filamentous red algae Laurencea sp. (0.39 g; $93.5 \%$ of total sample wet weight) but also contained macerated seagrass material $(0.03$ g; $6.5 \%$ of total mass). Skin tissue was run for stable isotopic analysis for the third lavage animal. Running the MixSIR model with the manatee discrimination factors resulted in a median estimated contribution of $67 \%$ macroalgae, $29 \%$ gelatinous macroplankton, and $3 \%$ seagrass, which supports the lavage findings for that individual. Stomach contents of

one stranded green turtle, which were not quantified, were dominated by macerated seagrass tissue and gelatinous material (L. Bejder pers. comm.).

\section{Animal-borne video}

Seventeen AVED deployments were made resulting in 12 usable videos for diet analysis (videos with poor camera placement or short ( $<90 \mathrm{~min}$ ) deployment durations 
were excluded from analysis). Eleven of the 12 turtles for which usable video were obtained (mean duration $=159.4 \mathrm{~min} \pm 7.2 \mathrm{~min} \mathrm{SE}$ ) recorded foraging during the deployment. Ten of the 12 fed on gelatinous macroplankton, 1 fed on algae, and 2 fed on seagrass. Most of the cnidarians/ctenophores were small, (body $<10 \mathrm{~cm}$ diameter). However, in one instance, a turtle pulled a large Phyllorhiza sp. jellyfish out of an area of dense Amphibolis antarctica and consumed it over the course of several minutes. Gelatinous macroplankton were consumed at a mean rate of $3.8 \pm 2.2 \mathrm{SE}$ ind. $\mathrm{h}^{-1}$ with a total of 112 items consumed. Macroalgae was consumed at a rate of $3.3 \pm 3.3 \mathrm{SE}_{\text {bites }}{ }^{-1}$ with a total of 141 bites taken, although all of these were from a single individual. Finally, only 7 bites of seagrass were recorded, resulting in a mean foraging rate of $0.2 \pm$ $0.1 \mathrm{SE}$ bites $\mathrm{h}^{-1}$.

\section{DISCUSSION}

Trophic interactions of green turtles

Green turtles are widely thought to be important herbivores in seagrass ecosystems through their impacts on growth patterns of seagrasses as well as detrital cycles (Thayer \& Engel 1982, Bjorndal 1997, Aragones \& Marsh 2000, Moran \& Bjorndal 2005, Aragones et al. 2006, Lal et al. 2010). Indeed, the loss of megaherbivores, including green turtles and sirenians, have been hypothesized to have resulted in extreme changes in seagrass communities, especially in the Caribbean (Bjorndal \& Jackson 1996, Jackson et al. 2001). In seeming contrast, recent studies have suggested that omnivory might be common in green turtles outside of the Caribbean (Heithaus et al. 2002a, Seminoff et al. 2006a, Arthur et al. 2007, Cardona et al. 2009). My study suggests that in 
a relatively pristine Australian seagrass ecosystem the reliance of the green turtle population on seagrass-derived primary production is smaller than would be expected on the basis of the abundance of seagrass resources. There is, however, a large degree of variation in individual turtle diets over time periods of at least months and, therefore, turtle impacts on seagrass communities likely are complex and more diverse than previously thought.

All three methods (AVED, stable isotopes, stomach contents) that I used to study turtle diets suggest that although seagrasses are extremely abundant in Shark Bay, neritic green turtles are not exclusively seagrass herbivores and may in fact consume relatively little of the available seagrass. Indeed, very few of the sampled green turtles had $\mathrm{d}^{13} \mathrm{C}$ similar to those of seagrasses even though other herbivores in the study area - including one hind-gut fermenter (dugong) - did have $\mathrm{d}^{13} \mathrm{C}$ similar to seagrasses. Green turtle tissues were more deplete in ${ }^{13} \mathrm{C}$ than were seagrasses and other herbivores, which was consistent with turtles assimilating carbon from gelatinous macroplankton and/or macroalgae. Also, many green turtles generally had $\mathrm{d}^{15} \mathrm{~N}$ values ca. $6 \%$ higher than seagrasses, suggesting the potential for 2 trophic levels of difference, even for some turtles with $\mathrm{d}^{13} \mathrm{C}$ signatures similar to seagrasses. The ${ }^{15} \mathrm{~N}$ values must be interpreted with caution, however, because of potentially large variation in fractionation values for herbivores such as green turtles (Martinez del Rio \& Wolf 2005). Despite this, the sample I obtained for a sympatric hind-gut fermenting herbivore (dugong) had a ${ }^{15} \mathrm{~N}$ much lower than most green turtles, suggesting that the large spread of $\mathrm{d}^{15} \mathrm{~N}$ in green turtle samples are unlikely to be the result of digestive processes alone. Previous studies using AVED and the additional video data presented here suggest that gelatinous macroplankton 
(primarily cnidarians and ctenophores) are commonly consumed by green turtles in Australia (Heithaus et al. 2002a, Arthur et al. 2007). It has been hypothesized that the consumption of this animal matter might be a response to capture stress and handling associated with the attachment of AVED (Arthur et al. 2007). Data from stable isotopes in Shark Bay, however, suggest that consumption of gelatinous macroplankton is widespread and occurs in turtles not fitted with AVED. Indeed, mixing models suggest that although turtles between 40 and $60 \mathrm{~cm}$ likely consume relatively little gelatinous macroplankton, at least some individual turtles $<60 \mathrm{~cm}$ CCL may get substantial energy from these invertebrates. New video data collected during my study suggest even higher foraging rates on gelatinous macroplankton than reported previously by Heithaus et al. (2002a).

Macroalgae also appears to be very important in the diets of green turtles in Shark Bay, even though its abundance is quite low relative to seagrasses in Shark Bay. Turtles $<60 \mathrm{~cm}$ likely derive almost all of their energy from macroalgae, and for larger turtles, macroalgae may make up half or more of their assimilated energy. While video data suggest that far more gelatinous macroplankton are consumed than macroalgae, it is possible that the nutritional content assimilated from these animals is lower than that obtained from seagrass or macroalgae. Regardless of the relative importance of macroalgae and gelatinous macroplankton for green turtles, seagrass and even seagrass and epiphytes together appear to represent $<5-20 \%$ of the energy assimilated. Video data seem to support the surprisingly low use of this abundant resource. Stable isotopic data do need to be interpreted with some caution, however. Hind-gut fermenters, like green turtles, may selectively route isotopes from different food sources to different purposes 
(Gannes et al. 1997, Martinez del Rio et al. 2009). Indeed, it appears that for some species, isotopes from high-protein food sources are more likely to be incorporated into tissues (Houpt \& Houpt 1968). If this is the case for green turtles, then seagrasses may be more important to their energy budgets than suggested by any of the mixing models I ran. If green turtles were exclusively, or even primarily, seagrass herbivores in Shark Bay, then variation in isotopic routing would be unlikely to produce such a diversity of isotopic values. The combination of isotopic, video, and lavage data strongly argue that non-epiphytic macroalgae and gelatinous macroplankton are important food sources for green turtles in Shark Bay.

The relatively high degree of omnivory in green turtles in Shark Bay is similar to findings from other areas of the world outside of the Caribbean. Upon recruitment to neritic habitats in Mauritania, green turtles do not make a rapid shift to an herbivorous diet as predicted (Cardona et al. 2009). Instead, many turtles continued to consume a largely animal-based diet. Isotopic mixing models suggest that animal prey, largely discards from local fisheries, accounted for $76-99 \%$ of the assimilated nutrients for animals between 29 and $59 \mathrm{~cm} \mathrm{CCL}$ and 53 and $76 \%$ of the assimilated nutrients for animals with CCL $>59 \mathrm{~cm}$. Likewise, Cardona et al. (2010) found that green turtles in the Mediterranean did not make a rapid shift to an herbivorous diet upon recruitment to neritic habitats, but instead made a slow conversion to a primarily seagrass-based diet. Green turtles in the central Gulf of California fed on a diverse assemblage of marine algae, which was supplemented by a suite of animal matter with 25 non-algal food species being identified from esophageal lavage, fecal samples, and stomach contents (Seminoff et al. 2002). The relatively high degree of omnivory outside of the Caribbean, 
however, is not universal. Indeed, stomach lavage and limited stable isotopic data from Shoalwater Bay in northeastern Australia suggest diets largely supported by seagrass but also consisting of a relatively large amount of red algae (Arthur et al. 2009).

Green turtles have the ability to modify seagrass distributions in some locations with intense grazing (see Thayer et al. 1984 for a review). Excluding green turtles from Thalassia testudinum beds in Bermuda for $1 \mathrm{yr}$ resulted in a seagrass biomass increase, an increase in the structural complexity of the seagrass canopy, and an increase in the length and width of seagrass blades compared to seagrass in grazed plots (Fourqurean et al. 2010). Murdoch et al. (2007) documented large-scale seagrass declines in Bermuda where about half of the offshore and lagoonal seagrass beds, which are far-removed from anthropogenic impacts, were gone or in obvious decline during the period between 1997 and 2004. The authors suggest that herbivory by green turtles and other herbivores might be a leading factor in this decline. My current study suggests that green turtles might be able to deal with a loss of seagrass by switching their diets to algae or gelatinous macroplankton, which might expand the impact that green turtles have on their environment by maintaining high population densities in the face of declining seagrass resources.

With more than $4000 \mathrm{~km}^{2}$ of seagrass in Shark Bay, it is quite surprising that turtle diets were not more similar to those in the Caribbean or Shoalwater Bay, where turtles rely heavily on seagrasses. Perhaps the relatively low use of seagrasses in my study area results from interspecific differences in the palatability of available seagrasses. However, in Moreton Bay, a seagrass-dominated ecosystem in northeast Australia, turtles include high proportions of macroalgae in their diets (Brand et al. 1999, Brand-Gardner 
et al. 1999). The slow-growing and relatively herbivory-resistant Amphibolis antarctica makes up the vast majority of the seagrass in the study area (Wirsing et al. 2007). Therefore, turtles may selectively forage on the less abundant but more palatable macroalgae and gelatinous plankton or turtles may assimilate relatively little carbon from seagrass that is consumed. In addition to the generally low quality of $A$. antarctica, the $A$. antarctica found along the edges of seagrass banks, where turtles are forced to forage for most of the year as a result of the high risk of tiger shark Galeocerdo cuvier predation in the middle of banks, are of lower quality than the $A$. antarctica found in the interior of seagrass banks (Heithaus et al. 2007). Interestingly, the manatee-based mixing model suggested slightly higher use of seagrasses during winter, when turtles could access higher-quality seagrass in the middle of banks because of relaxed predation risk. Increased seagrass use in the winter is consistent with the observations that predation risk keeps turtles that are in good condition out of seagrass beds with high-quality seagrass forage during summer months (Heithaus et al. 2007).

Although average diets of turtles in Shark Bay suggest relatively low rates of seagrass herbivory, it would be a mistake to assume that turtle foraging translates to green turtles having little or no impact on the Shark Bay seagrass ecosystem. Indeed, ongoing exclosure experiments suggest a large impact of megagrazers (green turtles and dugongs) on the more palatable, but much less abundant, tropical seagrass species found in the study area (D.A. Burkholder, unpubl. data). Furthermore, analysis of individual isotope values shows that some turtles had been feeding heavily on seagrasses, and it may take relatively few individual turtles to impact the dynamics of seagrass beds in Shark Bay, especially the growth and establishment of tropical species. Nonetheless, my results 
raise important questions about the dynamics of pristine seagrass communities. Green turtles are generally thought of as critical large herbivores that directly assimilate large amounts of seagrass-derived carbon into the food web (Bjorndal 1997, Jackson 1997 Valentine \& Duffy 2005, Heck \& Valentine 2007). However, in Shark Bay, green turtles appear to assimilate little seagrass-derived carbon, even when major portions of the Shark Bay food web are supported by seagrass-derived carbon. For example, the diverse ray and shark fauna are primarily feeding in seagrass-derived food webs and have $\mathrm{d}^{13} \mathrm{C}$ values, suggesting that these predators have a higher reliance on seagrass-derived carbon that is passed up the food chain than do green turtles in the same ecosystem (Vaudo \& Heithaus 2011).

\section{Individual specialization in turtle foraging?}

One of the most interesting aspects of green turtle foraging in Shark Bay was the extreme variation in isotopic values among individuals in the population. Variation among individual isotopic values can be driven by a number of factors, including shortterm differences in diets (for tissues with rapid turnover), long-term specialization on a subset of a population's resources that vary in isotopic composition ('individual specialization'), or individual differences in physiology (Hobson \& Clark 1992, Bearhop et al. 2004, Barnes et al. 2008). I consider the latter explanation unlikely for green turtles in my study because of the extreme spread in isotopic values. Laboratory studies suggest that individual variation in isotopic composition in laboratory raised wild bass showed coefficients of variation $(\mathrm{CV})$ of $2.6 \%$ for $\mathrm{d}^{15} \mathrm{~N}$, and $1.2 \%$ for $\mathrm{d}^{13} \mathrm{C}$ (Barnes et al. 2008), while green turtle $\mathrm{d}^{13} \mathrm{C}$ values in this study spanned more than $10 \%$. Although 
differential isotopic routing of high-protein vs. low-protein food sources may somewhat amplify differences among individuals with different diets (Gannes et al. 1997), the extreme spread of isotopic values observed in green turtles suggests that other behavioral variation among individuals is important. Indeed, the total isotopic niche space (sensu Layman et al. 2007) of green turtles is the highest measured to date of the 11 species studied in Shark Bay. In fact, the isotopic niche space of green turtles is greater than the combined area of 213 individuals from 13 species of rays and small sharks (36.1; Vaudo \& Heithaus 2011) and the generalist tiger shark (13.9, $n=93$; M. R. Heithaus unpubl. data). Green turtles also covered a wider isotopic area than loggerhead turtles (J. A. Thomson unpubl. data), which are considered generalist foragers at a population level but may exhibit individual specialization in other parts of their range (Vander Zanden et al. 2010).

That green turtle isotopic values covered such a large area of isotopic niche space is surprising considering the relatively slow turnover rate of the turtle tissues sampled, and suggests that differences among individuals are the result of specialization over time frames of at least many months. Although not studied in green turtles, muscle tissue of pond slider turtles Trachemys scripta took hundreds of days to complete a turnover cycle (Seminoff et al. 2007). Larger body sizes and slow-growing tissues are generally associated with longer tissue turnover times (Martinez del Rio et al. 2009); therefore, it is likely that the slowly growing subadult and adult green turtle tissues collected during the present study represent diets over even longer time periods. Indeed, turnover times of skin tissue sampled from another large reptile (juvenile American alligators) were over 1 yr (A. Rosenblatt unpubl. data). Therefore, the extreme spread in individual green turtle 
tissues suggests specialization on particular suites of resources over periods of at least months (Bolnick et al. 2003). Such specialization has been hinted at for subadult green turtles off the coast of Africa that also displayed substantial variance in isotopic signatures (Cardona et al. 2009). Further studies are needed to further elucidate the degree to which green turtles specialize in their foraging and the duration of this potential specialization. Indeed, isotopic studies that allow greater resolution of patterns of specialization, i.e., using multiple tissue types with different turnover rates are required, such as muscle, whole blood, and blood plasma, Matich et al. (2011), or time series from inert tissues, such as scutes, Cardona et al. (2009), Vander Zanden et al. (2010). Incorporating other techniques for assessing trophic interactions (e.g. fatty acids, compound-specific stable isotopes, stomach contents analysis) would help to further resolve green turtle diet composition and patterns of specialization.

There are several possible drivers of specialization in Shark Bay green turtles. First, individual specialization is expected when resources are scarce and individuals can forage more efficiently by foraging on a narrow set of resources (Bolnick et al. 2003, Svanback \& Bolnick 2005, 2007, Tinker et al. 2008). The green turtle population in Shark Bay exhibits characteristics of one near carrying capacity (Heithaus et al. 2005), which may partially be driven by the presence of tiger sharks in more resource-rich microhabitats that force most turtles to forage in more concentrated areas on poorer food sources (Heithaus et al. 2007). Therefore, although Shark Bay appears to be resourcerich, intraspecific competition may drive specialization by green turtles in Shark Bay. Alternatively, herbivore diet specialization may result from the gut microfloral assemblage of each individual. Seagrasses and algae differ in their structural 
carbohydrates, and the gut microflora necessary to aid in digestion of seagrasses is different than that necessary for digestion of algae (Bjorndal et al. 1991), and therefore turtles with different microflora may consistently select different foods. Stomach content analysis of 26 green turtles on the Orman Reefs, Torres Strait, Australia suggested some degree of specialization where 14 of the 26 turtles had stomach contents dominated by seagrass, 11 were dominated by macroalgae, and while mixed diets were not uncommon, only one individual had approx. equal proportions of seagrass and macroalgae in its stomach at the time of analysis. In Shark Bay, it appears that individual specialization involves not only specialization on specific single resources but also on mixes of macroalgae, seagrasses, and pelagic gelatinous animals. Therefore, it is likely that additional factors other than variation in intestinal microflora drive specialization patterns. Finally, differences in trophic interactions could result from individual turtles inhabiting home ranges with different resource suites. For example, if individual home ranges encompass offshore (oceanic) habitats, which tend to be more carbon-deplete or other foraging grounds, then this may be able to account for some degree of variation in isotopic values (Reich et al. 2010, Vander Zanden et al. 2010). This explanation, however, seems unlikely in Shark Bay as a consequence of the large distances to oceanic habitats, the low displacement of turtles tagged with AVED or time-depth recorders (TDR) for periods of several days (J. A. Thomson, unpubl. data), the similarity in benthic cover among banks where turtles were captured, and the lack of an effect of capture location on isotopic values. Detailed studies of turtle home ranges and movements are needed to adequately address this hypothesis. 


\section{CONCLUSION}

My study suggests that in relatively pristine ecosystems, like Shark Bay, green turtle foraging may be more complex than is generally appreciated and can be characterized by a relatively high degree of omnivory as well as individual specialization in foraging. Contrary to expectations, seagrass in this system is relatively unimportant to the assimilated carbon for green turtles, whereas macroalgae and animal tissue seem to be much more important and make up a much larger proportion of their diet. The relatively low food quality of seagrass within Shark Bay as well as foraging constraints imposed by the presence of tiger sharks (Heithaus et al. 2007, 2008) may partially drive the apparently low importance of seagrass to the turtle population as a whole. However, individual diet specialization in green turtles leads to some individuals foraging heavily on seagrass and highlights the importance of incorporating individual-level data on foraging and behavior into considerations of the ecological role of green turtles and management strategies for their protection.

\section{Acknowledgements}

I thank the Monkey Mia Dolphin Resort for providing lodging and logistical support. Special thanks to the numerous field assistants. J. Vaudo provided statistical advise. Thanks are also due to M. Donnelly and C. Layman for helpful comments on previous drafts of this manuscript. Funding for this project was provided by National Science Foundation grants OCE0526065 and OCE0745606 to M. Heithaus, Florida International University, and PADI Aware Grant \# 253 to D. Burkholder. Research was 
conducted under DEC permits SF002752, NE002120, SF005394, CE001338, SF006804, CE002357 and subsequent annual renewals. Research was conducted with authorization from FIU's IACUC and with SFU UACC certification. This is contribution \#52 of the Shark Bay Ecosystem Research Project. 


\section{Literature Cited}

Alves-Stanley CD, Worthy GAJ (2009) Carbon and nitrogen stable isotope turnover rates and diet-tissue discrimination in Florida manatees (Trichechus manatus latirostris). J Exp Biol 212:2349-2355

Aragones LV, Marsh H (2000) Impact of dugong grazing and turtle cropping on tropical seagrass communities. Pac Conserv Biol 5:277-288

Aragones LV, Lawler IR, Foley WJ, Marsh H (2006) Dugong grazing and turtle cropping: Grazing optimization in tropical seagrass systems? Oecologia 149:635-647

Araújo MS, Gonzaga MO (2007) Individual specialization in the hunting wasp Trypoxylon (Trypargilum) albonigrum (Hymenoptera, Crabronidae). Behav Ecol Sociobiol 61: 1855-1863

Araújo MS, Bolnick DI, Martinelli LA, Giaretta AA, dos Reis SF (2009) Individual-level diet variation in four species of Brazilian frogs. J Anim Ecol 78:848-856

Arthur KE, O’Neil JM, Limpus CJ, Abernathy K, Marshall G (2007) Using animal-borne imaging to assess green turtle (Chelonia mydas) foraging ecology in Moreton Bay, Australia. Mar Technol Soc J 41:9-13

Arthur KE, Boyle MC, Limpus CJ (2008) Ontogenetic changes in diet and habitat use in green sea turtle (Chelonia mydas) life history. Mar Ecol Prog Ser 362:303-311

Arthur KE, McMahon KM, Limpus CJ, Dennison WC (2009) Feeding ecology of green turtles (Chelonia mydas) from Shoalwater Bay, Australia. Mar Turtle Newsl $123: 6-12$

Baird RW, Abrams PA, Dill LM (1992) Possible indirect interactions between transient and resident killer whales: implications for the evolution of foraging specializations in the genus Orcinus. Oecologia 89:125-132

Barnes C, Jennings S, Polunin NVC, Lancaster JE (2008) The importance of quantifying inherent variability when interpreting stable isotope field data. Oecologia 155: $227-235$

Bearhop S, Adams CE, Waldron S, Fuller RA, Macleod H (2004) Determining trophic niche width: a novel approach using stable isotope analysis. J Anim Ecol 73:

$1007-1012$ 
Bizzarro JJ, Robinson HJ, Rinewalt CS, Ebert DA (2007) Comparative feeding ecology of four sympatric skate species off central California, USA. Environ Biol Fishes 80:197-220

Bjorndal KA (1980) Nutritional and grazing behavior of the green turtle Chelonia mydas. Mar Biol 56:147-154

Bjorndal KA (1997) Foraging ecology and nutrition of sea turtles. In: Lutz PL, Musick JA (eds) The biology of sea turtles. CRC Press, Boca Raton, FL, p 199-231

Bjorndal KA, Jackson JBC (1996) Roles of sea turtles in marine ecosystems: reconstructing the past. In Lutz PL, Musick JA, Wyneken J (eds) The biology of sea turtles, Vol 2. CRC Press, Boca Raton, FL, p 259-273

Bjorndal KA, Suganuma H, Bolten AB (1991) Digestive fermentation in green turtles, Chelonia mydas, feeding on algae. Bull Mar Sci 48:166-171

Bolnick DI, Svanback R, Fordyce JA, Yang LH, Davis JM, Hulsey, CD, and Forister MI (2003) The ecology of individuals: incidence and implications of individual specialization. Am Nat 161:1-28

Borowitzka MA, Lethbridge RC, Charlton L (1990) Species richness, spatial distribution and colonization pattern of algal and invertebrate epiphytes on the seagrass Amphibolis griffithii. Mar Ecol Prog Ser 64:281-291

Brand SJ, Lanyon JM, Limpus CJ (1999) Digesta composition and retention times in wild immature green turtles, Chelonia mydas: a preliminary investigation. Mar Freshw Res 50:145-147

Brand-Gardner SJ, Lanyon JM, Limpus CJ (1999) Diet selection by immature green turtles, Chelonia mydas, in sub-tropical Moreton Bay, south-east Queensland. Aust J Zool 47:181-191

Burkholder, D. A., J. W. Fourqurean, and M. R. Heithaus. In press. Spatial pattern in seagrass stoichiometry indicates both $\mathrm{N}$-limited and P-limited regions of an iconic P-limited subtropical bay. Marine Ecology Progress Series. DOI: $10.3354 /$ meps 10042

Cardona L, Aguilar A, Pazos L (2009) Delayed ontogenetic dietary shift and high levels of omnivory in green turtles (Chelonia mydas) from the NW coast of Africa. Mar Biol 156:1487-1495

Cardona L, Campos P, Levy Y, Demetropoulos A, Margaritoulis D (2010) Asynchrony between dietary and nutritional shifts during the ontogeny of green turtles (Chelonia mydas) in the Mediterranean. J Exp Mar Biol Ecol 393:83-89 
Carruthers TJB, Dennison WC, Longstaff BJ, Waycott M and others (2002) Seagrass habitats of Northeast Australia: models of key processes and controls. Bull Mar Sci 71: 1153-1169

Caut S, Angulo E, Courchamp F (2009) Variation in discrimination factors $(\Delta 15 \mathrm{~N}$ and $\Delta 13 \mathrm{C})$ : the effect of diet isotopic values and applications for diet reconstruction. J Appl Ecol 46:443-453

Chaloupka M, Limpus CJ (2001) Trends in the abundance of sea turtles resident in southern Great Barrier Reefwaters. Biol Conserv 102:235-249

Darimont CT, Paquet PC, Reimchen TE (2009) Landscape heterogeneity and marine subsidy generate extensive intrapopulation niche diversity in a large terrestrial vertebrate. J Anim Ecol 78:126-133

DeNiro MJ, Epstein S (1981) Influence of diet on the distribution of nitrogen isotopes in animals. Geochim Cosmochim Acta 45:341-351

Ehrhart LM, Ogren LH (1999) Studies in foraging habitats: capturing and handling turtles. In: Eckert KL, Bjorndal KA, Abreu-Grobois FA, Donnelly M (eds) Research and management techniques for the conservation of sea turtles. IUCN/SSC Marine Turtle Specialist Group Publication, Vol 4. Consolidated Graphic Communications, Blanchard, PA, p 61-65

Estes JA, Reidman ML, Staedler MM, Tinker MT, Lyon BE (2003) Individual variation in prey selection by sea otters: patterns, causes, and implications. J Anim Ecol 72: $144-155$

Felicetti LASC, Rye RO, Haroldson MA, Unther KA, Philips DL, Robbins CT (2003) Use of sulphur and nitrogen stable isotopes to determine the importance of whitebark pine nuts to Yellowstone grizzly bears. Can J Zool 81: 763-770

Forbes GA (1994) The diet of the green turtle in an algal- based community - Heron Island, Australia. In: Schroeder BA, Witherington BE (eds) Proceedings of the Thirteenth Annual Symposium on Sea Turtle Biology and Conservation. NOAA Tech Memo NMFS-SEFSC-341. Department of Commerce, Washington, DC, $p$ $57-59$

Forbes GA, Limpus C (1993) A non-lethal method for retrieving stomach contents from sea turtles. Wildl Res 20:339-343

Fourqurean JW, Manuel S, Coates KA, Kenworthy WJ, Smith SR (2010) Effects of excluding sea turtle herbivores from a seagrass bed: Overgrazing may have led to loss of seagrass meadows in Bermuda. Mar Ecol Prog Ser 419:223-232 
Gannes LZ, O’Brien DM, Martinez del Rio C (1997) Stable isotopes in animal ecology: assumptions, caveats, and a call for more laboratory experiments. Ecology 78: $1271-1276$

Hamann M, Godfrey MH, Seminoff JA, Arthur K, Barata PCR, Bjorndal KA, Bolten AB, Broderick AC, Campbell LM, Carreras C, Casale P, Chaloupka M, Chan SKF, Coyne MS, Crowder LB, Diez CE, Dutton PH, Epperly SP, FitzSimmons NN, Formia A, Girondot M, Hays GC, Cheng IJ, Kaska Y, Lewison R, Mortimer JA, Nichols WJ, Reina RD, Shanker K, Spotila JR, Tomás J, Wallace BP, Work TM, management and conservation in the 21st century. Endang Species Res 11:245-269

Hammerschlag-Peyer CM, Layman CA (2010) Intrapopulation variation in habitat use by two abundant coastal fish species. Mar Ecol Prog Ser 415:211-220

Harrison SM, Zazzo A, Baha B, Monahan FJ, Moloney AP, Scrimgeour CM, Schnidt O (2007) Using hooves for high-resolution isotopic reconstruction of bovine dietary history. Rapid Commun Mass Spectrom 21:479-486

Heck KL, Valentine JF (2007) The primacy of top-down effects in shallow benthic ecosystems. Estuaries Coasts 30:371-381

Heithaus MR, McLash JJ, Frid A, Dill LM, Marshall GJ (2002a) Novel insights into green sea turtle behaviour using animal-borne video cameras. J Mar Biol Assoc UK 82:1049-1050

Heithaus MR, Frid A, Dill LM (2002b) Species and sex-class differences in shark Inflicted injury frequencies, escape ability, and habitat use of green and loggerhead turtles. Mar Biol 40:229-236

Heithaus MR, Frid A, Wirsing A, Bejder L, Dill LM (2005) Biology of sea turtles under risk from tiger sharks at a foraging ground. Mar Ecol Prog Ser 288:285-294

Heithaus MR, Wirsing AJ, Frid A, Dill LM (2007) Species interactions and marine conservation: lessons from an undisturbed ecosystem. Israel J Ecol Evol $53: 355-370$

Heithaus MR, Frid A, Wirsing AJ, Worm B (2008) Predicting ecological consequences of marine top predator declines. Trends Ecol Evol 23:202-210

Hobson KA, Clark RG (1992) Assessing avian diets using stable isotopes I: turnover of 13C in tissues. Condor 94: 181-188 
Hooker SK, Iverson SJ, Ostrom P, Smith SC (2001) Diet of northern bottlenose whales inferred from fatty-acid and stable-isotope analyses of biopsy samples. Can J Zool 79: $1442-1454$

Houpt TR, Houpt KA (1968) Transfer of urea nitrogen across the rumen wall. Am J Physiol 214:1296-1303

Hyslop EJ (1980) Stomach content analysis - a review of methods and their application. J Fish Biol 17:411-429

Jackson JBC (1997) Reefs since Columbus. Coral Reefs 16: S23-S32

Jackson JBC, Kirby MX, Berger WH, Bjorndal KA and others (2001) Historical overfishing and the recent collapse of coastal ecosystems. Science 293:629-637

Kuiper-Linley M, Johnson CR, Lanyon JM (2007) Effects of simulated green turtle regrazing on seagrass abundance, growth and nutritional status in Moreton Bay, southeast Queensland, Australia. Mar Freshw Res 58:492-503

Lal A, Arthur R, Marbá N, Lill AWT, Alcoverro T (2010) Implications of conserving an ecosystem modifier: Increasing green turtle (Chelonia mydas) densities substantially alters seagrass meadows. Biol Conserv 143: 2730-2738

Layman CA, Arrington DA, Montana CG, Post DM (2007) Can stable isotope ratios provide for community-wide measures of trophic structure? Ecology 88:42-48

Martinez del Rio C, Wolf BO (2005) Mass balance models for animal isotope ecology. In: Starck MA, Wang T (eds) Physiological and ecological adaptations to feeding in vertebrates. Science Publishers, Enfield, NH, p 141-174

Martinez del Rio C, Wolf N, Carleton SA, Gannes LZ (2009) Isotopic ecology ten years after a call for more laboratory experiments. Biol Rev Camb Philos Soc 84:91-111

Matich P, Heithaus MR, Layman CA (2011) Contrasting patterns of individual specialization and trophic coupling in two marine apex predators. J Anim Ecol 80:294-305

Minagawa M, Wada E (1984) Stepwise enrichment of $15 \mathrm{~N}$ along food chains: further evidence and the relation between $15 \mathrm{~N}$ and animal age. Geochim Cosmochim Acta 48:1135-1140

Moore JW, Semmens BX (2008) Incorporating uncertainty and prior information into stable isotope mixing models. Ecol Lett 11:470-480 
Moran KL, Bjorndal KA (2005) Simulated green turtle grazing affects structure and productivity of seagrass pastures. Mar Ecol Prog Ser 305:235-247

Mortimer JA (1981) The feeding ecology of the West Caribbean green turtle (Chelonia mydas) in Nicaragua. Biotropica 13:49-58

Murdoch TJT, Glasspool AF, Outerbridge M, Ward J and others (2007) Large-scale decline in offshore seagrass meadows in Bermuda. Mar Ecol Prog Ser 339:123-130

Newsome SD, Tinker MT, Monson DH, Oftedal OT, Ralls K, Staedler MM, Fogel ML, Estes JA (2009) Using stable isotopes to investigate individual diet specialization in California sea otters (Enhydra lutris nereis). Ecology 90:961-974

Peterson BJ, Fry B (1987) Stable isotopes in ecosystem studies. Annu Rev Ecol Syst $18: 293-320$

Post DM (2002) Using stable isotopes to estimate trophic position: models, methods, and assumptions. Ecology 83: 703-718

Post DM, Layman CA, Arrington DA, Takimoto G, Montaña CG, Quattrochi J (2007) Getting to the fat of the matter: models, methods and assumptions for dealing with lipids in stable isotope analyses. Oecologia 152:179-189

Read MA, Limpus CJ (2002) The green turtle, Chelonia mydas, in Queensland: feeding ecology of immature turtles in Moreton Bay, Southeastern Queensland. Mem Queensl Mus 48:207-214

Reich KJ, Bjorndal KA, Bolten AB (2007) The 'lost years' of green turtles: using stable isotopes to study cryptic lifestages. Biol Lett 3:712-714

Reich KJ, Bjorndal KA, Martinez del Rio C (2008) Effects of growth and tissue type on the kinetics of $13 \mathrm{C}$ and $15 \mathrm{~N}$ incorporation in a rapidly growing ectotherm. Oecologia 15:651-663

Reich KJ, Bjorndal KA, Frick MG, Witherington BE, Johnson C, Bolten AB (2010) Polymodal foraging in adult female loggerheads (Caretta caretta). Mar Biol 157:113-121

Rendell L, Whitehead H (2001) Culture in whales and dolphins. Behav Brain Sci 24:309-324

Rosenblatt AE, Heithaus MR (2011) Does variation in movement tactics and trophic interactions among American alligators create habitat linkages? J Anim Ecol 80: 786-798 
Seminoff JA, Resendiz A, Nichols WJ (2002) Diet of east Pacific green turtles (Chelonia mydas) in the Central Gulf of California, Mexico. J Herpetol 36:447-453

Seminoff JA, Jones TT, Marshall GJ (2006a) Underwater behavior of green turtles monitored with video-time-depth recorders: what's missing from dive profiles? Mar Ecol Prog Ser 322:269-280

Seminoff JA, Jones TT, Eguchi T, Jones DR, Dutton PH (2006b) Stable isotope discrimination $(\delta 13 \mathrm{C}$ and $\delta 15 \mathrm{~N})$ between soft tissues of the green sea turtle Chelonia mydas and its diet. Mar Ecol Prog Ser 308:271-278

Seminoff JA, Bjorndal KA, Bolten AB (2007) Stable carbon and nitrogen isotope discrimination and turnover in pond sliders Trachemys scripta: insights for trophic study of freshwater turtles. Copeia 2007:534-542

Svanbäck R, Bolnick DI (2005) Intraspecific competition affects the strength of individual specialization: an optimal diet theory method. Evol Ecol Res 7:993-1012

Svanbäck R, Bolnick DI (2007) Intraspecific competition drives increased resource use diversity within a natural population. Proc Biol Sci 274:839-844

Svanbäck R, Persson L (2004) Individual diet specialization, niche width, and population dynamics: implications for trophic polymorphisms. J Anim Ecol 73:973-982

Thayer GW, Engel DW (1982) Evidence for short circuiting of the detritus cycle of seagrass beds by the green turtle Chelonia mydas. J Exp Mar Biol Ecol 62:173-183

Thayer GW, Bjorndal KA, Ogden JC, Williams SL, Zieman JC (1984) Role of larger herbivores in seagrass communities. Estuaries 7:351-376

Tinker MT, Bentall G, Estes JA (2008) Food limitation leads to behavioral diversification and dietary specialization in sea otters. Proc Natl Acad Sci USA 105:560-565

Valentine JF, Duffy JE (2005) The central role of grazing in seagrass ecology. In: Larkum AWD, Orth RJ, Duarte CM (eds) Seagrasses: biology, ecology and conservation. Springer, Dordrecht, p 463-501

Vander Zanden HB, Bjorndal KA, Reich KJ, Bolten AB (2010) Individual specialists in a generalist population: results from a long-term stable isotope series. Biol Lett 6: $711-714$

Vaudo J, Heithaus MR (2011) Dietary niche overlap in a nearshore elasmobranch mesopredator community. Mar Ecol Prog Ser 425:247-260 
Wabnitz CCC, Balazs G, Beavers S, Bjorndal KA, Bolten AB, Christensen V, Hargrove S, Pauly D (2010) Ecosystem structure and processes at Kaloko Hanokohau, focusing on the role of herbivores, including the green sea turtle Chelonia mydas, in reef resilience. Mar Ecol Prog Ser 420:27-44

Walker DI, McComb AJ (1988) Seasonal variation in the growth, biomass, and nutrient status of Amphibolis antarctica (Labill. Sonder ex Aschers. and Posidonia australis Hook. f. in Shark Bay, Western Australia. Aquat Bot 31:259-275

Walker DI, Kendrick GA, McComb AJ (1988) The distribution of seagrass species in Shark Bay, Western Australia, with notes on their ecology. Aquat Bot 30:305-317

Wirsing AJ, Heithaus MR, Dill LM (2007) Living on the edge: dugongs prefer to forage in microhabitats that allow escape from rather than avoidance of predators. Anim Behav 74:93-101 
Table 1. Chelonia mydas. Estimated diet compositions of green turtles in Shark Bay, Western Australia, based on 3 assumptions about isotopic discrimination factors. Two sets of MixSIR, a Bayesian-mixing model, were used. Skin tissue taken from the filler was analyzed in both sets. Seagrass was run as a resource pool without epiphytes in Set 1 but with epiphytes (epi) in Set 2. Isotopic values of potential food sources used in models: algae $\left(\delta^{13} \mathrm{C}=-15.55 \pm 2.61 ; \delta^{15} \mathrm{~N}=3.52 \pm 0.75\right)$, seagrass $\left(\delta^{13} \mathrm{C}=-9.41 \pm 1.32\right.$; $\delta^{15} \mathrm{~N}=0.77 \pm 1.62$ ), gelatinous macroplankton (gel. macropl.) combined for $<60 \mathrm{~cm}$ curved carapace length $(\mathrm{CCL})\left(\delta^{13} \mathrm{C}=-17.68 \pm 1.40 ; \delta^{15} \mathrm{~N}=7.24 \pm 0.56\right)$, gel. macropl. in summer $\left(\delta^{13} \mathrm{C}=-17.89 \pm 0.68 ; \delta^{15} \mathrm{~N}=6.82 \pm 0.65\right)$, gel. macropl. in winter $\left(\delta^{13} \mathrm{C}=-\right.$ $\left.19.27 \pm 0.27 ; \delta^{15} \mathrm{~N}=7.58 \pm 0.35\right)$. Values are medians with 5 th and 95 th percentiles in parentheses

\begin{tabular}{|c|c|c|c|c|c|}
\hline \multirow[b]{2}{*}{ Set 1} & \multirow[b]{2}{*}{$\mathrm{N}$} & \multirow[b]{2}{*}{ Assumption } & \multicolumn{3}{|c|}{ Resource Pool } \\
\hline & & & Algae & Gel. macropl. & Seagrass \\
\hline \multirow{3}{*}{ Turtles $<60 \mathrm{~cm}$ CCL } & 8 & Seminoff et al. 2006b & $0.87(0.74-0.98)$ & $0.12(0.02-0.26)$ & $0.00(0.00-0.02)$ \\
\hline & 8 & Caut et al. 2009 & $0.86(0.72-0.98)$ & $0.14(0.02-0.27)$ & $0.00(0.00-0.02)$ \\
\hline & 8 & Alves-Stanley \& Worthy 2009 & $0.96(0.94-1.00)$ & $0.01(0.00-0.04)$ & $0.01(0.00-0.04)$ \\
\hline \multicolumn{6}{|l|}{ Turtles $\geq 60 \mathrm{~cm} \mathrm{CCL}$} \\
\hline \multirow[t]{3}{*}{ All Seasons } & 57 & Seminoff et al. 2006b & $0.77(0.73-0.80)$ & $0.23(019-0.27)$ & $0.00(0.00-0.01)$ \\
\hline & 57 & Caut et al. 2009 & $0.74(0.70-0.78)$ & $0.26(0.22-0.29)$ & $0.00(0.00-0.01)$ \\
\hline & 57 & Alves-Stanley \& Worthy 2009 & $0.98(0.95-1.00)$ & $0.00(0.00-0.01)$ & $0.02(0.00-0.05)$ \\
\hline \multicolumn{6}{|l|}{ Summer } \\
\hline & 26 & Seminoff et al. 2006b & $0.81(0.75-0.87)$ & $0.19(0.12-0.25)$ & $0.00(0.00-0.02)$ \\
\hline & 26 & Caut et al. 2009 & $0.79(0.73-0.86)$ & $0.20(0.14-0.26)$ & $0.00(0.00-0.01)$ \\
\hline & 26 & Alves-Stanley \& Worthy 2009 & $0.99(0.96-1.00)$ & $0.00(0.00-0.01)$ & $0.01(0.00-0.04)$ \\
\hline \multicolumn{6}{|l|}{ Winter } \\
\hline & 31 & Seminoff et al. 2006b & $0.78(0.74-0.83)$ & $0.21(0.17-0.25)$ & $0.00(0.00-0.02)$ \\
\hline & 31 & Caut et al. 2009 & $0.75(0.71-0.79)$ & $0.25(0.21-0.29)$ & $0.00(0.00-0.02)$ \\
\hline & 31 & Alves-Stanley \& Worthy 2009 & $0.89(0.83-0.96)$ & $0.01(0.00-0.02)$ & $0.10(0.04-0.16)$ \\
\hline Set 2 & $\mathrm{~N}$ & Assumption & Algae & Gel. macropl. & Seagrass + Epi \\
\hline \multirow[t]{3}{*}{ Turtles $<60 \mathrm{~cm} \mathrm{CCL}$} & 8 & Seminoff et al. 2006b & $0.87(0.74-0.98)$ & $0.12(0.02-0.25)$ & $0.01(0.00-0.02)$ \\
\hline & 8 & Caut et al. 2009 & $0.86(0.73-0.97)$ & $0.13(0.02-0.27)$ & $0.00(0.00-0.02)$ \\
\hline & 8 & Alves-Stanley \& Worthy 2009 & $0.96(0.93-0.99)$ & $0.01(0.00-0.04)$ & $0.01(0.00-0.05)$ \\
\hline \multicolumn{6}{|l|}{ Turtles $\geq 60 \mathrm{~cm} \mathrm{CCL}$} \\
\hline \multirow[t]{3}{*}{ Summer } & 26 & Seminoff et al. 2006b & $0.81(0.75-0.87)$ & $0.19(0.12-0.25)$ & $0.01(0.00-0.02)$ \\
\hline & 26 & Caut et al. 2009 & $0.79(0.73-0.86)$ & $0.20(0.14-0.26)$ & $0.00(0.00-0.02)$ \\
\hline & 26 & Alves-Stanley \& Worthy 2009 & $0.99(0.97-1.00)$ & $0.00(0.00-0.01)$ & $0.01(0.00-0.03)$ \\
\hline \multicolumn{6}{|l|}{ Winter } \\
\hline & 31 & Seminoff et al. 2006b & $0.78(0.74-0.83)$ & $0.21(0.17-0.25)$ & $0.00(0.00-0.02)$ \\
\hline & 31 & Caut et al. 2009 & $0.75(0.71-0.79)$ & $0.25(0.21-0.29)$ & $0.00(0.00-0.02)$ \\
\hline & 31 & Alves-Stanley \& Worthy 2009 & $0.89(0.79-0.98)$ & $0.00(0.00-0.02)$ & $0.10(0.01-0.20)$ \\
\hline
\end{tabular}


Table 2. Chelonia mydas. MixSIR predicted diet compositions for extreme individual turtles (animals selected at extreme range of the carbon and nitrogen spectrums to encompass all possible values) based on discrimination factors of juvenile green turtles (Seminoff et al. 2006b) and juvenile loggerhead turtles (Reich et al. 2008). Values are medians with 5th and 95th percentiles in parentheses U: unclassed; M: male; Gel. macropl.: gelatinous macroplankton

\begin{tabular}{|c|c|c|c|c|c|c|}
\hline \multirow[b]{2}{*}{ Length } & \multirow[b]{2}{*}{ Sex } & \multirow[b]{2}{*}{$\delta^{15} \mathrm{~N}$} & \multirow[b]{2}{*}{$\delta^{13} \mathrm{C}$} & \multicolumn{3}{|c|}{ Resource pool } \\
\hline & & & & Algae & Gel. macropl. & Seagrass \\
\hline \multicolumn{7}{|c|}{ Seminoff et al. (2006b) } \\
\hline 61.5 & $\mathrm{U}$ & 6.69 & -9.80 & $0.18(0.01-0.86)$ & $0.08(0.01-0.21)$ & $0.72(0.07-0.91)$ \\
\hline 68.0 & $\mathrm{U}$ & 10.61 & -19.00 & $0.03(0.00-0.13)$ & $0.95(0.86-0.99)$ & $0.01(0.00-0.05)$ \\
\hline 104.0 & $\mathrm{U}$ & 7.12 & -22.44 & $0.84(0.66-0.96)$ & $0.12(0.01-0.30)$ & $0.03(0.00-0.10)$ \\
\hline 96.0 & $\mathrm{M}$ & 5.56 & -14.31 & $0.44(0.06-0.81)$ & $0.19(0.02-0.48)$ & $0.36(0.11-0.55)$ \\
\hline 88.0 & $\mathrm{U}$ & 5.76 & -20.58 & $0.85(0.69-0.96)$ & $0.07(0.01-0.21)$ & $0.06(0.01-0.19)$ \\
\hline 95.5 & $\mathrm{U}$ & 9.63 & -16.48 & $0.09(0.01-0.36)$ & $0.69(0.59-0.76)$ & $0.22(0.01-0.31)$ \\
\hline 103.0 & $\mathrm{U}$ & 9.47 & -13.15 & $0.06(0.00-0.29)$ & $0.37(0.19-0.48)$ & $0.56(0.40-0.71)$ \\
\hline 80.0 & $\mathrm{U}$ & 6.61 & -11.29 & $0.27(0.02-0.82)$ & $0.17(0.02-0.35)$ & $0.55(0.08-0.79)$ \\
\hline \multicolumn{7}{|c|}{ Caut et al. (2009) } \\
\hline 61.5 & $\mathrm{U}$ & 6.69 & -9.80 & $0.20(0.01-0.83)$ & $0.13(0.02-0.31)$ & $0.63(0.07-0.86)$ \\
\hline 68.0 & $\mathrm{U}$ & 10.61 & -19.00 & $0.03(0.00-0.12)$ & $0.94(0.85-0.98)$ & $0.02(0.00-0.07)$ \\
\hline 104.0 & $\mathrm{U}$ & 7.12 & -22.44 & $0.85(0.67-0.97)$ & $0.11(0.01-0.29)$ & $0.03(0.00-0.10)$ \\
\hline 96.0 & M & 5.56 & -14.31 & $0.53(0.12-0.86)$ & $0.15(0.01-0.43)$ & $0.32(0.07-0.51)$ \\
\hline 88.0 & $\mathrm{U}$ & 5.76 & -20.58 & $0.87(0.72-0.97)$ & $0.06(0.00-0.19)$ & $0.05(0.00-0.17)$ \\
\hline 95.5 & $\mathrm{U}$ & 9.63 & -16.48 & $0.09(0.01-0.26)$ & $0.84(0.70-0.95)$ & $0.05(0.01-0.15)$ \\
\hline 103.0 & $\mathrm{U}$ & 9.47 & -13.15 & $0.08(0.01-0.30)$ & $0.76(0.53-0.91)$ & $0.13(0.01-0.39)$ \\
\hline 80.0 & $\mathrm{U}$ & 6.61 & -11.29 & $0.28(0.02-0.80)$ & $0.22(0.03-0.43)$ & $0.48(0.08-0.73)$ \\
\hline \multicolumn{7}{|c|}{ Alves-Stanley and Worthy (2009) } \\
\hline 61.5 & $\mathrm{U}$ & 6.69 & -9.80 & $0.26(0.03-0.58)$ & $0.13(0.01-0.24)$ & $0.59(0.36-0.78)$ \\
\hline 68.0 & $\mathrm{U}$ & 10.61 & -19.00 & $0.54(0.08-0.87)$ & $0.44(0.10-0.87)$ & $0.02(0.00-0.08)$ \\
\hline 104.0 & $\mathrm{U}$ & 7.12 & -22.44 & $0.94(0.85-0.99)$ & $0.03(0.00-0.09)$ & $0.03(0.00-0.11)$ \\
\hline 96.0 & M & 5.56 & -14.31 & $0.57(0.41-0.79)$ & $0.03(0.00-0.12)$ & $0.39(0.19-0.53)$ \\
\hline 88.0 & $\mathrm{U}$ & 5.76 & -20.58 & $0.93(0.80-0.99)$ & $0.02(0.00-0.06)$ & $0.04(0.00-0.18)$ \\
\hline 95.5 & $\mathrm{U}$ & 9.63 & -16.48 & $0.63(0.38-0.88)$ & $0.31(0.07-0.54)$ & $0.05(0.00-0.16)$ \\
\hline 103.0 & $\mathrm{U}$ & 9.47 & -13.15 & $0.42(0.07-0.78)$ & $0.41(0.14-0.63)$ & $0.18(0.02-0.36)$ \\
\hline 80.0 & $\mathrm{U}$ & 6.61 & -11.29 & $0.38(0.06-0.68)$ & $0.11(0.01-0.35)$ & $0.49(0.28-0.67)$ \\
\hline
\end{tabular}




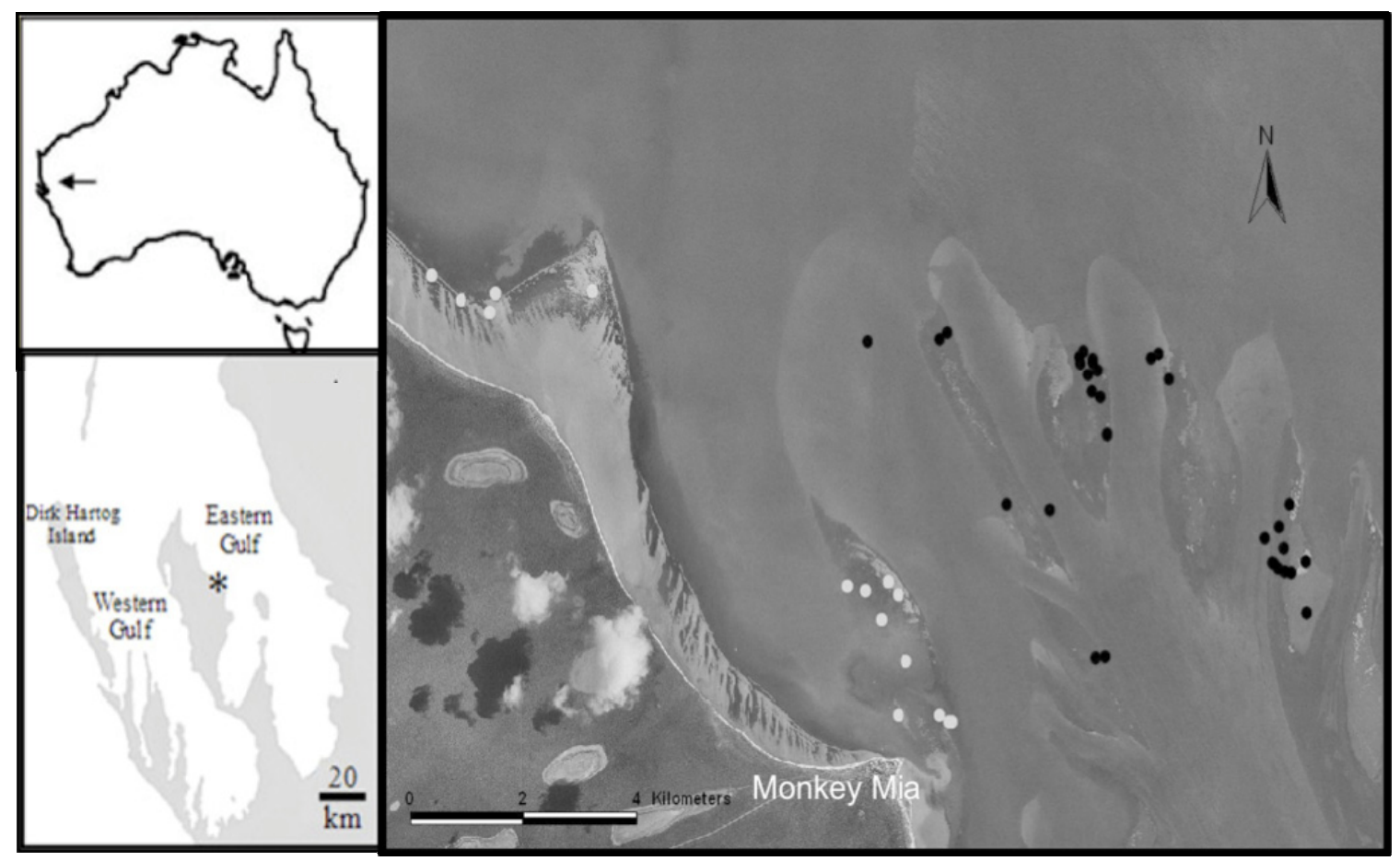

Figure 1: Location of the study site $\left(^{*}\right)$ in the Eastern Gulf of Shark Bay, Western Australia. Points represent capture location of green turtles sampled for stable isotopic composition. White points: captures in the nearshore habitat; black points: captures in the offshore seagrass bank habitat 


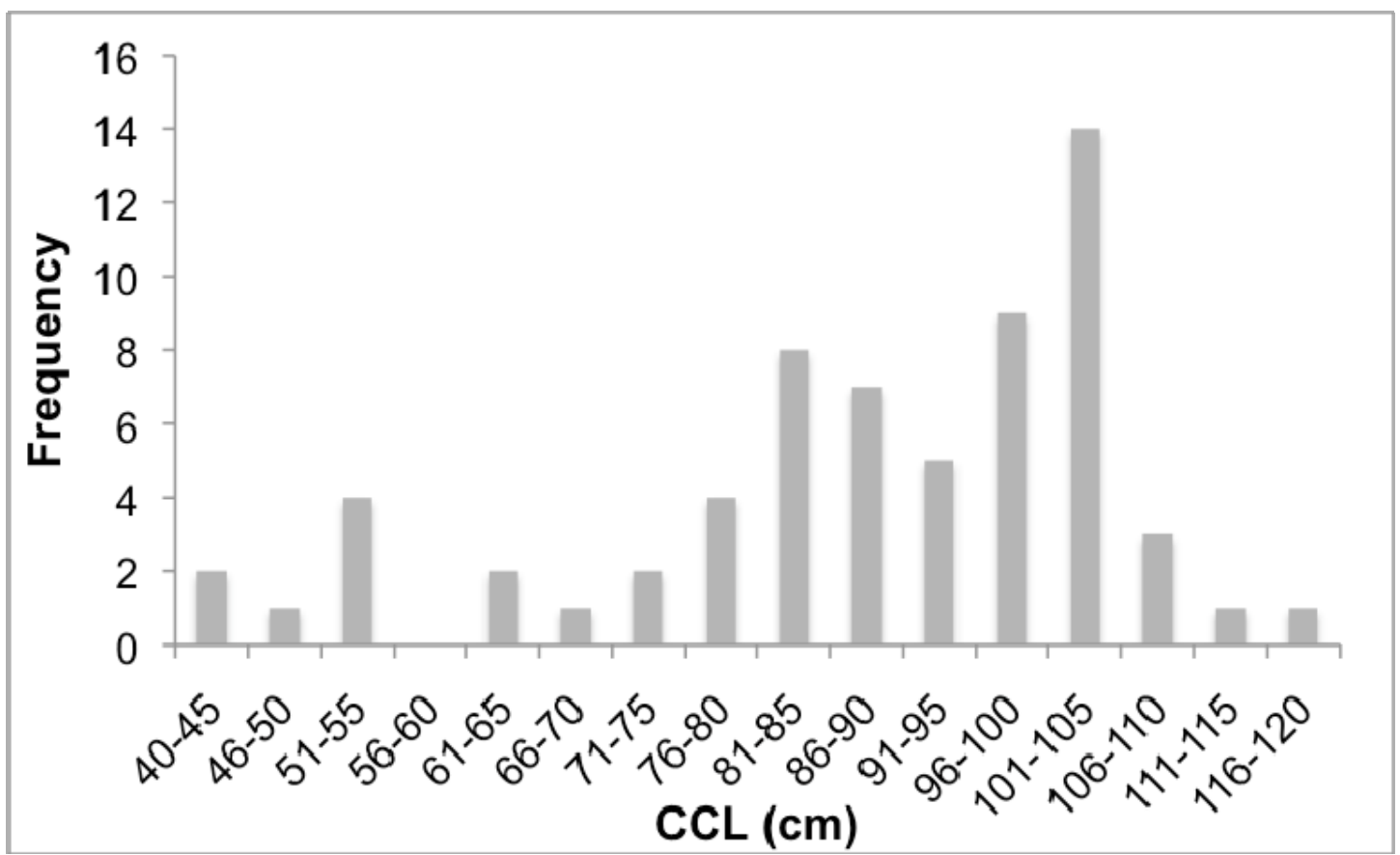

Figure 2: Chelonia mydas. Size distribution of individuals sampled for stable isotopic analysis 


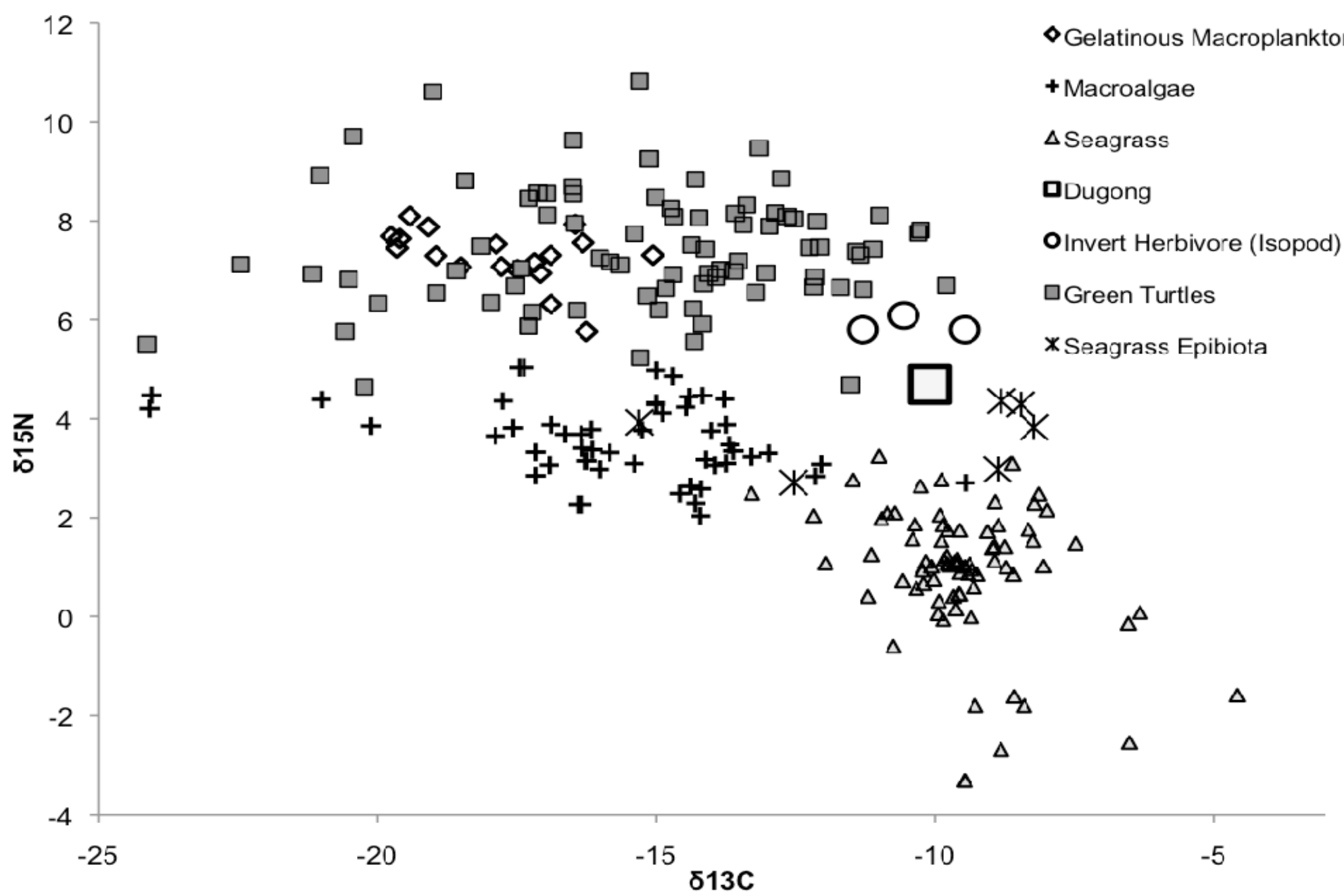

Figure 3: Isotopic values of individual green turtles, their potential food resources, and representative herbivores in Shark Bay, Australia 
a)

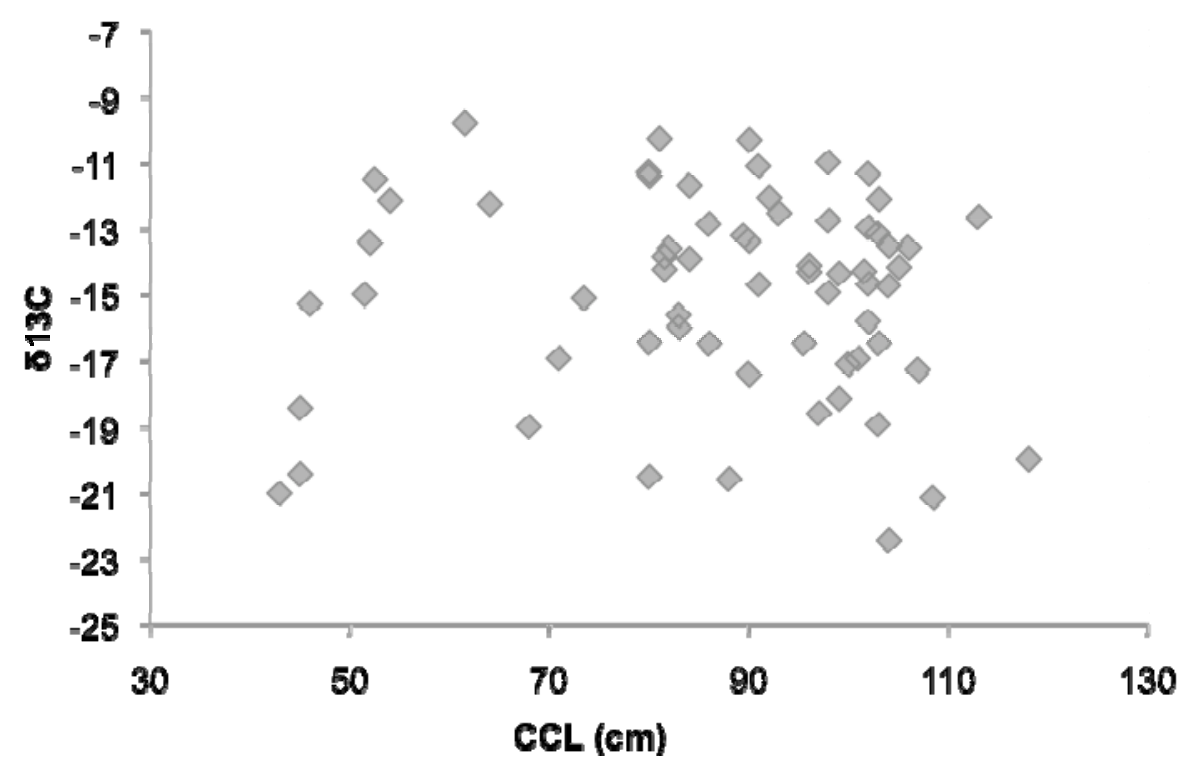

b)

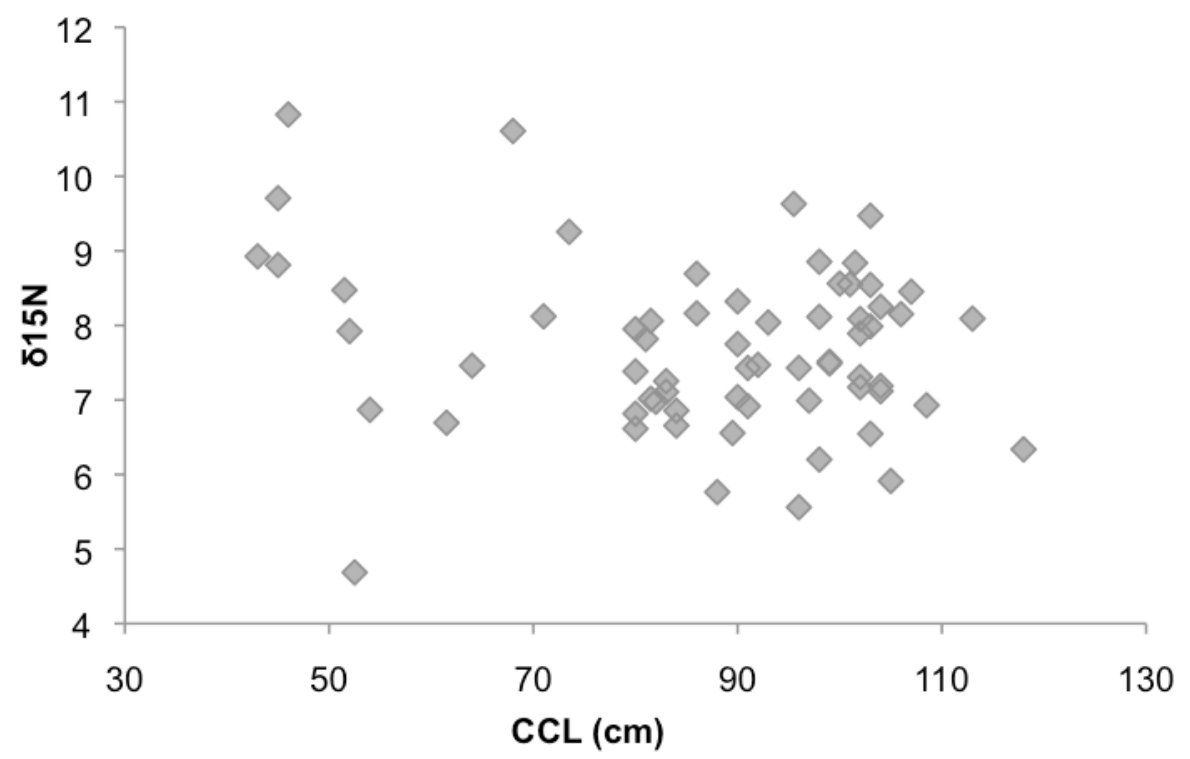

Figure 4: Chelonia mydas. Influence of curved carapace length (CCL, in $\mathrm{cm})$ on (a) $\delta^{13} \mathrm{C}$ and (b) $\delta^{15} \mathrm{~N}$ values 
CHAPTER V

PATTERN OF TOP-DOWN CONTROL OF A SEAGRASS ECOSYSTEM: COULD A ROVING TOP PREDATOR INDUCE A BEHAVIOR-MEDIATED TROPHIC CASCADE? 


\section{Abstract}

The loss of large-bodied herbivores and/or top predators has been associated with large-scale changes in ecosystems around the world. Yet, there remain important questions regarding the contexts in which such changes are most likely, and the mechanisms through which they occur, particularly in marine ecosystems. I used longterm exclusion cages to examine the effects of large grazers (sea cows, sea turtles) on seagrass community structure, biomass, and nutrient dynamics and how these effects might be structured by non consumptive effects of tiger sharks (Galeocerdo cuvier), a roving predator. Release from large herbivore grazing pressure resulted in increased leaf length for the tropical seagrass species Cymodocea angustata and Halodule uninervis. However, C. angustata shoot densities nearly tripled when released from herbivory while H. uninervis nearly disappeared from exclusion cages over the course of the study. While both dugongs and green turtles contribute to these impacts, a grazing halo inside cages suggests that turtles likely play an important role in seagrass removal. Contrary to predictions, I found little support for the hypothesis that grazing increases seagrass nutrient content. In fact, phosphorus content increased significantly in seagrasses released from herbivory. Finally, spatial variation in top-down impacts of large grazers were consistent with a behavior-mediated trophic cascade (BMTC) initiated by tiger sharks and mediated by risk-sensitive foraging by large grazers. Our results suggest that large-bodied grazers likely played important roles in seagrass ecosystem dynamics historically, and that roving predators are capable of initiating BMTC. Conservation efforts in coastal ecosystems must account for such interactions or risk unintended consequences. 


\section{Introduction}

Trophic downgrading of ecosystems - the loss of large-bodied herbivores and/or top predators - has been associated with large-scale changes in terrestrial, freshwater, and marine ecosystems around the world (Estes et al. 2011). Trophic cascades initiated by the removal of top predators have been well studied in small scale and experimental settings. These studies have shown that predators can modify primary producer community structure, biomass, and nutrient composition indirectly, both through removing prey individuals (predation or direct killing) and inducing behavioral changes in herbivores ("risk" or "non-consumptive" effects) (e.g. Pace et al. 1999, Preisser et al. 2005, Schmitz 2006). There remain, however, important gaps in our understanding of the prevalence and mechanisms of herbivore-mediated indirect impacts of predators on primary producer communities. Indeed, recent studies of these indirect relationships have raised questions about whether small-scale experiments might scale up to diverse ecosystems, whether vertebrate predators may be less likely to trigger trophic cascades than insect predators, and if roving predators are likely to initiate behavior-mediated trophic cascades (Shurin and Seabloom 2005, Schmitz 2008, Kauffman et al. 2010). Increasingly, ecologists have recognized the potential importance of nonconsumptive (or risk) effects of predators in structuring herbivore-primary producer interactions. For example, in an old-field system with herbaceous plants, grasshopper herbivores, and spider predators, grasshoppers experienced significantly higher mortality in experiments with spiders that had their chelicerae glued (risk spiders) and in unglued (predatory spiders) trials when compared to a no-spider control (Schmitz et al. 1997). In some situations, risk effects may rival or even exceed the influence of direct predation on 
prey populations and communities (Werner and Peacor 2003, Preisser et al. 2005, Creel and Christianson 2008, Creel 2011). As an example, Schmitz et al. (1997) found that "risk" and "predatory" spiders had statistically similar top-down effects on the relationship between grasshoppers and grass biomass. However, few studies of cascading effects of risk (i.e., behaviorally mediated indirect species interactions [BMII] or behavior-mediated trophic cascades [BMTC]) have been carried out in large-scale ecosystems with intact populations of predators and herbivores. One notable exception is Yellowstone National Park, where the restoration of wolf (Canis lupus) populations apparently triggered behavioral changes in elk (Cervus elaphus) that led in turn to increased recruitment of aspen (Populus tremuloides) and changes in the wider community (Ripple and Beschta 2004, Creel et al. 2005, Hernández and Laundré 2005, Fortin et al. 2005). Recent studies, however, have raised questions about the presence of behavior-mediated cascades in Yellowstone (Kauffman et al. 2010).

More broadly, it has been suggested that roving (or actively hunting) predators, like wolves, might not exert strong behavior-mediated impacts on communities because of the limited scope for prey anti-predator behavior to be effective (Schmitz and Suttle 2001, Kauffman et al. 2010). Specifically, roving predators have a more spatially diffuse risk signature that is less predictable by potential prey, which may limit anti-predator behavior. Studies from marine systems, however, suggest that roving predators can have substantial impacts on prey behavior in heterogeneous landscapes where prey can predictably modify their probabilities of encounter with and/or escape from predators (Heithaus et al. 2009, Wirsing et al. 2010). Whether these prey spatial responses to roving predators might cascade to lower trophic levels, however, remains to be tested. 
Here, I explore whether tiger sharks (Galeocerdo cuvier), as a roving predator, might elicit a behavior-mediated tropic cascade by inducing predation sensitive habitat shifts in green sea turtles and dugongs in the seagrass ecosystem of Shark Bay, Western Australia.

Despite the economic importance of seagrass as habitat for many species (Heck et al. 2003) and as a carbon sink (Duarte et al. 2010, Fourqurean et al. 2012), many aspects of seagrass ecology remain poorly understood. For example, the importance of herbivory in structuring seagrass communities has only recently been appreciated (e.g., Armitage and Fourqurean 2006, Heck and Valentine 2007). While early studies suggested little seagrass entered food webs through direct grazing pathways (Fry et al.1987), recent work has demonstrated that megagrazers (e.g., green turtles, Chelonia mydas and dugongs, Dugong dugon) can impact seagrass biomass, production, nutrient cycling, and community structure (Thayer and Engel 1982, de Iongh et al. 1995, Bjorndal 1997, Aragones \& Marsh 2000, Masini et al. 2001, Moran \& Bjorndal 2005, Fourqurean et al. 2010, Lal et al. 2010). Yet, it remains unclear whether these megagrazer impacts are representative of ecosystem dynamics under natural conditions (e.g. Heck and Valentine 2006, 2007). Indeed, most studies of seagrass herbivory to date have occurred in areas where communities, including populations of both megagrazers and their potential predators (sharks), have been heavily modified by humans (Jackson 1997, Heck and Valentine 2007 Jackson et al. 2001). Indeed, Jackson et al. (2001) suggest that seagrass communities historically would have had much lower biomass and a vastly different community structure because of unrestricted grazing by herbivores. However, the structure of historical seagrass communities also may have been structured by behavioral responses of large herbivores to their predators (see Heithaus et al. 2007a, 2008); this 
possibility has been largely overlooked. Therefore, current conservation targets and understanding of pristine ecosystem structure could be the result of a "shifting baseline", resulting in an inaccurate estimation of the role these large grazers and top predators played in structuring seagrass ecosystems historically.

With its large shark and large herbivore populations, Shark Bay offers a unique opportunity to investigate the role of top predators and large herbivores in structuring seagrass ecosystems. I used exclusion cages to test a priori predictions of spatial variation in top-down impacts of large herbivores based on known predation-sensitive foraging behavior by dugongs (Wirsing et al. 2007 a,b,c) and green turtles (Heithaus et al. 2007a). Briefly, predation risk from tiger sharks results in both grazer species concentrating their foraging effort in safer areas along the edges of seagrass banks while avoiding the more dangerous interior portions of the banks. Therefore, I predicted that 1) megagrazer impacts on seagrasses would be stronger in edge microhabitats than in interior portions of shallow banks, and 2) that release from grazing pressure would result in changes in seagrass community and nutrient composition of seagrasses in edge, but not interior, microhabitats.

\section{Materials and Methods}

Study Site

The study was conducted in the Eastern Gulf of Shark Bay, Western Australia $\left(\sim 25^{\circ} 45^{\prime} \mathrm{S}, 113^{\circ} 44^{\prime} \mathrm{E}\right)$. Shark Bay is a shallow $(<15 \mathrm{~m})$ subtropical bay that is dominated by seagrass beds covering approximately $4,000 \mathrm{~km}^{2}$ (Walker et al. 1988). Shark Bay is one of the few remaining seagrass ecosystems in the world with near 
pristine populations of both large-bodied herbivores (green turtles and dugongs; Preen et al. 1997, Heithaus et al. 2005) and the roving predators (tiger sharks) that feed on them (Heithaus et al. In press). Therefore, Shark Bay affords a unique opportunity to examine the effects of large herbivores and their predators on seagrass community dynamics. The seagrass community, which experiences minimal anthropogenic impacts, is a diverse assemblage of temperate and tropical seagrass species. The dominant species in the bay are slower growing temperate species, including Amphibolis antarctica, Posidonia australis, and Posidonia coriacea. Smaller, faster-growing species, primarily of tropical origin, including Halophila ovalis, Halophila spinulosa, Halophila decipiens, Halophila minor, Halodule uninervis, Cymodocea angustata, and Syringodium isoetifolium (Walker et al. 1988, Burkholder et al. in press a), are less abundant. Biomass turnover rates of Amphibolis antarctica and Posidonia sp. (3.8 to $\left.3.9 \mathrm{y}^{-1}\right)$ are much slower than smaller taxa like Cymodocea spp. (11.7-12.0y $\left.\mathrm{y}^{-1}\right)$, Syringodium spp. (11.0-13.7 $\left.\mathrm{y}^{-1}\right)$, Halodule spp. $\left(13.9 \mathrm{y}^{-1}\right)$ and Halophila spp. (17.2-32.4 $\left.\mathrm{y}^{-1}\right)($ Duarte 1991).

My study site in the Eastern Gulf of Shark Bay is characterized by a series of shallow $(<4.5 \mathrm{~m})$ seagrass banks separated by deeper channels $(6-11 \mathrm{~m})$ mostly covered by sand. Shallow habitats can be further subdivided into two microhabitats - interior portions of banks and bank edges - that vary in the risk tiger sharks pose to large-bodied herbivores, the abundance of these large herbivores, and seagrass community structure and biomass (see Heithaus et al. 2007a; Wirsing et al. 2007b; Burkholder et al. in press a). For large herbivores, edge microhabitats are higher-risk than interior microhabitats and both dugongs and green turtles preferentially forage in these edge microhabitats during periods of high shark abundance, which lasts 9-12 months of the year (Heithaus et 
al. 2007a, Wirsing et al. 2007b, Heithaus et al. 2012). Green turtles are present yearround in the study area, but during low-risk periods in winter reduce foraging rates considerably (Thomson et al. unpublished data), making it unlikely that they would forage extensively in interior microhabitats. Dugongs forage in both interior and edge microhabitats during brief periods when tiger shark abundances are lower and dugongs are present in the study area (Wirsing et al. 2007b). During the majority of the year, however, dugongs have either moved to thermally favorable habitats outside the study area (when shark abundances are lowest) or are present in the study area when tiger shark abundance is high and, therefore, forage in edge microhabitats. Additionally, dugongs reduce "dangerous" excavation foraging and increase the "safe" cropping foraging tactic, which allows for increased vigilance when sharks are present (Wirsing et al. 2007c). Thus, like green turtles, dugong foraging impacts are expected to be concentrated in edge microhabitats. Based on these predation-sensitive behaviors, I predicted that excluding herbivores from foraging would have large consequences for seagrasses in edge microhabitats and minimal impacts on seagrasses within interior microhabitats.

\section{Field Methods}

From September 2007- May 2010, I used exclusion cages to determine the impacts of megaherbivore grazing on seagrass community structure, shoot density, blade length, and nutrient content within both high- and low-shark risk areas (interior and edge microhabitats, respectively). The cages consisted of a $2.5 \times 3 \mathrm{~m}$ top of galvanized rebar with $20 \times 20 \mathrm{~cm}$ mesh suspended $c a .20 \mathrm{~cm}$ above the substrate with aluminum fence droppers secured with wire and zip ties. Rebar sides of the same material as tops were 
attached to the top and extended into the substrate. Shoot densities and blade length were assessed in four fixed quadrats $(60 \mathrm{~cm} \times 60 \mathrm{~cm}$ each) within each cage approximately bimonthly throughout the study. Cages were cleaned of drifting debris and epiphytic growth as needed. Control plots were designated by a single fence dropper that facilitated serial measurements at four fixed quadrats $(60 \mathrm{~cm} \times 60 \mathrm{~cm}$ each). Cages were constructed on the margin of $A$. antarctica beds, extending into sand substrate where tropical seagrass species are most prevalent (Burkholder et al. in press a). Because of herbivore preferences for fast-growing species in this system (Burkholder et al. in press b) and apparent resilience of $A$. antarctica to grazing (Burkholder et al. in press a,b), I focused my analyses on the three fast-growing taxa in our study area (Cymodocea angustata, Halodule uninervis, and Halophila ovalis).

I constructed cages and controls in each of the different habitats/microhabitats (deep, seagrass edge, seagrass interior). Interior cages/controls were constructed in waters 1.5 to 3 meters deep, edge cages/controls were constructed in waters 3-5 meters deep, while deep cages/controls were constructed in waters $\sim 10$ meters deep. It proved impossible to prevent cages in deep habitats from being destroyed by swift currents, so I focused on comparisons of edge and interior microhabitats.

I established 20 control and 20 experimental plots ( 5 cages and 5 controls at edge and interior microhabitats across 2 seagrass banks) in September 2007. In January 2008 one set of 5 edge microhabitat cages and controls experienced extremely heavy sedimentation and scouring resulting in removal of those cages. In November 2008, I reestablished these plots in a new location where they were maintained for the duration of the experiment concluding in May 2010. The reestablished set of edge experiments ran 
for nearly 600 days while the initial set of edge cages that were not compromised and both sets of interior cages ran for nearly 1000 days. There was no significant change in seagrass communities or densities between day 600 and day 1000 for the 3 sets of experiments that were maintained. Therefore, I truncated my datasets to 600 days in order to include all plots in analyses. I do not include plots that were only present for $c a$. 90 days.

At the end of the experiment, I collected seagrass from one quadrat of each plot using a $15 \mathrm{~cm}$ diameter PVC core tube. The core was pushed into the sediment 20 centimeters and then removed, collecting the seagrass both above (leaves and stems) and below (roots and rhizomes) ground. Seagrass samples were stored on ice in the field and immediately frozen to $-20^{\circ} \mathrm{C}$ upon return to shore until they could be processed for elemental analysis.

At the conclusion of the experiment, the exclusion cages were removed and the sites were revisited at 24 and 72 hours after deconstruction to examine aboveground seagrass tissue removal. The same four fixed quadrats $(60 \mathrm{~cm} \times 60 \mathrm{~cm})$ were sampled for shoot densities. To compare removal rates among species and plots with differing starting shoot densities, I converted remaining densities at each time step to the proportion of seagrass remaining. Only plots with more than 10 total blades at the removal of the exclusion cage were included in analyses.

\section{Laboratory Methods}

Upon return to the laboratory, all seagrass tissue was rinsed in deionized water. Leaf tissue was gently scraped with a razor blade to remove and collect epibiota, which 
was analyzed on its own. Above and below-ground tissue were dried for at least 24 hours in a food dehydrator (Ezidri Ultra FD1000) and then crushed to a powder with mortar and pestle for elemental content analysis. Carbon $(\mathrm{C})$ and nitrogen $(\mathrm{N})$ content of samples were measured using an elemental analyzer (Fisons NA1500) and phosphorus (P) content was measured using a dry-oxidation/acid hydrolysis method (Fourqurean et al. 1992).

\section{Results}

Combined shoot counts of fast-growing seagrasses, derived from initial counts in both caged $(n=20)$ and control plots $(n=20)$, varied between edge and interior areas at the beginning of trials $(\mathrm{t}=4.44, \mathrm{P}<0.0001)$. Fast growing seagrasses were abundant in edges $\left(\right.$ mean $=278.6$ shoots $\left./ \mathrm{m}^{2} \pm 60.9 \mathrm{SE}\right)$ and scarce in interior plots (mean $=3.7$ shoots $\left./ \mathrm{m}^{2} \pm 1.9 \mathrm{SE}\right)$. Species composition of fast-growing species also varied between edges and interiors. Only Halodule uninervis was found in interior plots (mean $=3.7$ shoots $\left./ \mathrm{m}^{2} \pm 1.9 \mathrm{SE}\right)$, but at lower densities than in edge plots $\left(\right.$ mean $=104.8$ shoots $/ \mathrm{m}^{2} \pm$ 33.2 SE; $\mathrm{t}=3.04, \mathrm{P}<0.0001)$. At the initiation of experiments, plots in the edge microhabitat also contained the fast-growing species Cymodocea angustata $($ mean = 162.5 shoots $\left./ \mathrm{m}^{2} \pm 30.1 \mathrm{SE}\right)$, Halophila ovalis (mean $=3.8$ shoots $\left./ \mathrm{m}^{2} \pm 1.9 \mathrm{SE}\right)$, and occasionally Halophila spinulosa $\left(\right.$ mean $=0.03$ shoots $\left./ \mathrm{m}^{2} \pm 0.03 \mathrm{SE}\right)$.

There was a significant effect of treatment on the change in $H$. uninervis densities within interior microhabitats $(\mathrm{t}=2.04, \mathrm{P}=0.04)$, but this difference was driven primarily by variation in starting densities within exclosure and control plots. Indeed, all plots with H. uninervis present at the start of the experiment experienced shoot density declines and by the end of the study shoots of $H$. uninervis were only present in one plot. There were, 
however, sporadic temporary increases in shoot densities of $H$. uninervis within both exclosures and control plots, including plots that began with no above-ground shoots (Figure 2). Despite these sporadic outbreaks, shoot densities quickly declined from densities at the start of the experiment.

Seagrass shoot densities varied considerably between exclosures and control sites at the conclusion of the experiment in edge trials (Figure 3). Densities of C. angustata were influenced by an interaction of treatment and time step (Table 1). Densities increased substantially in exclosures, but did not change in control plots (Figure 4). The heights of $C$. angustata almost tripled within exclosures, but did not change within control plots $(\mathrm{t}=20.48, \mathrm{df}=341, \mathrm{P}<0.0001$; Figure 5). Densities of $H$. uninervis varied with the interaction of time step and treatment (Table 1), but not in the same way as for C. angustata. Halodule uninervis densities declined within exclosures but remained consistent in control plots (Figure 4). The heights of H. uninervis, however, were approximately 1.5 times greater inside exclosures than in control sites at the end of the experiment $(\mathrm{t}=5.23, \mathrm{df}=133, \mathrm{P}<0.0001$; Figure 5$)$. The density of $H$. ovalis did not vary with any factor (Table 1). There was no difference in blade lengths between treatments $(\mathrm{t}=1.48, \mathrm{df}=31, \mathrm{P}<=0.07$; Figure 5$)$.

In edge microhabitats, there was no effect of long-term exclusion of megaherbivores on $\mathrm{C}: \mathrm{N}$ and N:P ratios, for any species (Table 2, Figure 6). Phosphorus content was higher (i.e., lower C:P), however, in Cymodocea angustata and Halodule uninervis inside exclusion cages than in control plots. There was no effect for Halophila ovalis (Figure 6). 
The proportion of seagrass shoots remaining within plots after removal of cages was influenced by an interaction of species and time $\left(\mathrm{F}_{2,41}=4.69, \mathrm{P}=0.016\right)$. Cymodocea angustata densities were reduced 30\% in the first 24 hours, but densities were not reduced significantly over the following 48 hours (Figure 7). Halodule uninervis densities were reduced by approximately $40 \%$ in the first 24 hours and continued to decline to an average of $25 \%$ of shoots remaining after 72 hours. Unfortunately, blade lengths were not measured during the removal experiment. However, 24 hours after cage removal the height of $C$. angustata had been cropped to lengths similar to those of blades found outside of exclusion plots.

\section{Discussion}

Understanding the importance of top-down control in natural ecosystems is critical for establishing conservation and management baselines and predicting ecosystem responses to natural and anthropogenic change. Yet, there is continued debate about the strength of top-down control and the conditions in, and mechanisms through, which it is more or less likely to occur. Using a combination of previously published studies of the behavioral responses of large herbivores (green turtles, dugongs) to the presence of top predators (tiger sharks) and my exclusion experiments, I provide evidence that top-down control by large herbivores is important in determining plant biomass and species relative abundance in a relatively pristine seagrass ecosystem and that the spatial pattern of these impacts likely is mediated by risk effects of a roving top predator. These results provide important insights into the dynamics of seagrass ecosystems as well as more general 
insights into the potential for roving predators to trigger behavior-mediated trophic cascades in intact ecosystems.

Marine megaherbivores have been shown to impact seagrass ecosystems in other locations. For example, Nakaoka et al. (2002) found that only about $3 \%$ of the dry weight of $H$. ovalis remained in foraging trails left by dugongs that excavated seagrass rhizomes. Benthic animal taxa richness and densities were reduced more than 50\% inside dugong foraging trails relative to undisturbed H. ovalis stands (Nakaoka et al. 2002). Grazing does not merely reduce biomass of plants, but it can also mediate the outcomes of competition among plants in the community. Dugong grazing in Queensland, Australia, caused Halophila ovalis, a fast growing, pioneer seagrass species, to show a 12-fold increase in shoot density in response to the 6-fold decrease in shoot density of the competitively dominant Zostera capricorni, (Preen 1995). Herbivores can also influence other processes in the grazed ecosystem. Thayer and Engel (1982) found that green turtle grazing can considerably increase the decomposition rate of seagrass species such as Thalassia testudinum, and repeated grazing of seagrass patches by green turtles in the Caribbean may increase seagrass forage quality by causing the production of new leaves that are higher in nutrient content and therefore more easily digested (Bjorndal 1980). However, intense overgrazing by green turtles may also result in shifts in seagrass community structure (Kuiper-Linley et al. 2007, Wabnitz et al. 2010) and eventually cause significant declines in seagrass biomass and productivity (Williams 1988, Murdoch et al. 2007, Fourqurean et al. 2010). The above studies have, in general, been conducted in ecosystems with either greatly reduced or rebounding populations of dugongs and green turtles and likely reduced populations of predatory sharks (Chaloupka et al. 2008, 
Baum and Myers, 2004, Marsh et al. 2005). Thus, how megaherbivores might impact seagrass ecosystems in ecosystems where populations of both these grazers and their predators are intact has remained unclear (e.g. Heck and Valentine 2006).

In Shark Bay, populations of both large grazers and top predators are intact (Preen et al. 1997, Heithaus et al. 2005, in press) and seagrasses are free from anthropogenic water quality degradation and physical disturbance that have heavily impacted coastal ecosystems around the world (Orth et al. 2006, Waycott et al. 2009). Previous studies have shown that, in Shark Bay, tiger sharks elicit strong anti-predator behavior in marine megaherbivores (Heithaus et al. 2007a,b, Wirsing et al. 2007a,b,c, 2011). These responses result in a concentration of grazing pressure on seagrasses along the edges of banks, where predation risk is lower, while relaxing grazing pressure within interior microhabitats where risk to large grazers is higher. The reduced densities of megagrazers in the latter areas are also accompanied by a substantial reduction in excavation foraging (Wirsing et al. 2007d), which facilitates fast growing species (Preen 1995), by dugongs that do forage under increased risk. I found that the seagrass communities in edge habitats were much more strongly influenced by megaherbivore exclusion than those from interior habitats. In interior habitats, where megaherbivore grazing is low because of high shark abundance, exclusion cages had little impact. But, in edge habitats in which megaherbivore grazing is concentrated by shark presence, the exclusion of the megaherbivores greatly influenced the abundance, species composition and nutrient content of seagrasses. These results are consistent with predictions of risk-sensitive foraging by large herbivores, and suggest that green turtles and dugongs affect the structure, function, and nutrient content of seagrasses in the edge microhabitats where 
they are concentrated while apparently having little role in structuring at least the fastgrowing seagrass community within the more dangerous interior microhabitats. Thus, spatial variation in megagrazer impacts on seagrasses likely is driven by risk effects of tiger sharks.

Within edge microhabitats, seagrass communities changed when protected (exclusion cages) from megagrazer herbivory. Cymodocea angustata densities increased substantially and shoots grew basically as tall as the exclosure cage. Cymodocea angustata remained smaller in stature and in lower densities outside exclosures. In contrast, although Halodule uninervis inside exclosures grew taller than it did at control sites, its densities declined in exclosure plots over the course of 600 days. Whether this decline is the result of competitive exclusion by $C$. angustata or its removal by smaller herbivores that could enter the exclosures is unclear, because teleost herbivores show a strong preference for $H$. uninervis over C. angustata (Burkholder et al. in press b). The former explanation may be somewhat more likely since remaining $H$. uninervis shoots might be expected to be of similar, or shorter, heights to control plots if fish grazing had been responsible for the declines. The importance of herbivory by large-bodied grazers in driving observed patterns of seagrass community structure and above ground biomass in edge microhabitats, however, is further supported by the rapid reduction in densities of C. angustata and $H$. uninervis at the conclusion of the experiment, when the exclosures were removed and exposed previously protected seagrasses.

Our results from interior microhabitats are somewhat harder to interpret. Above ground biomass of fast-growing species was initially lower in interior microhabitats than edge microhabitats despite similar depths of plots and the presence of fast-growing 
species in shallow areas in other portions of the bay with different spatial configurations (i.e., much larger continuous shallow banks; Burkholder et al. in press a). There did appear, however, to be below-ground structures of these species in our plots or the plots experienced sporadic successful seed germination and recruitment because shoots appeared periodically during our sampling even in plots where there had been no shoots in previous sampling time periods. Regardless of being inside exclosures or in control plots, however, these shoots quickly disappeared. Together, these data suggest that largebodied grazers do not drive the relative lack of fast-growing species in interior microhabitats of my study area, which would be expected because of their avoidance of these areas in response to risk from tiger sharks. The factors limiting the maintenance of fast-growing species in these areas could be physical ones or herbivory from smallerbodied species not excluded by my experiments. The latter explanation seems more likely since the fast-growing species often are found in shallow waters in other locations and herbivorous teleosts that could enter our exclosure cages prefer fast-growing species like H. uninervis (Burkholder et al. in press b) and are common in interior microhabitats (Heithaus 2004). Recent experimental studies aimed at separating the impacts of herbivorous fish and megagrazers on the establishment and maintenance of fast-growing seagrass species (including C. angustata and H. uninervis) in interior microhabitats confirmed that fish grazing is important in these habitats and that minimal megagrazer impacts are not simply due to the strength of top-down impacts by fishes (Bessey et al. in preparation). The combination of light grazing by megaherbivores (especially excavation grazing by dugongs that facilitates fast-growing species; Preen 1995) and heavy fish grazing (particularly on fast-growing species; Burkholder et al. 2012, Bessey 
et al. in preparation) in interior microhabitats may drive the dominance of the slowgrowing species $A$. antarctica in these areas.

The apparent importance of fish grazing in interior microhabitats (Bessey et al. in preparation) combined with an apparent lack of fish grazing in edge microhabitats suggests that parallel trophic pathways that link tiger sharks to seagrasses might be operating in Shark Bay. Pelates cf. octolineatus (once P. sexlineatus) is highly abundant in the study area (Heithaus 2004) and is prey of dolphins (Tursiops cf. aduncus; Heithaus and Dill 2002). Dolphins, like megagrazers, respond to tiger shark predation risk by largely abandoning shallow microhabitats when sharks are present (Heithaus and Dill 2006), allowing teleosts to graze relatively risk-free, and concentrate in edge microhabitats, which would increase risk to fishes and potentially lower their impacts on seagrasses. Thus, tiger sharks may structure spatiotemporal variation in seagrass communities through parallel behavior-mediated trophic cascades.

The nutrient content of the two most common seagrass species varied between control plots and exclosures. In general, grazing by turtles and dugongs is thought to result in increased nutrient content in seagrass blades, thereby increasing the nutritional value of seagrasses in heavily cropped areas (Bjorndal 1980, 1997, Zieman et al. 1984, Aragones et al. 2006). However, Thayer et al. (1984) suggested that heavy grazing by marine megagrazers would eventually result in decreased nutrient content as removal of biomass by grazers depleted the stores of available nutrients in the sediments available to the plants. Here, I found that although there were no changes in C:N or N:P ratios of seagrasses released from herbivory, the C:P ratio decreased (i.e., P content increased) when $C$. angustata and H. uninervis were released from herbivory. This could be 
evidence that intense grazing by megaherbivores in Shark Bay seagrasses causes a decrease in sediment nutrient availability in heavily grazed areas, and that a reduction in the grazing losses results in an increase in the $\mathrm{P}$ available for plant growth.

I was not able to separate the relative importance of green turtle and dugong grazing in driving seagrass responses in edge microhabitats. At the population level, stable isotope analyses suggest that green turtles in the study area do not appear to rely heavily on seagrasses as a food source, although some individuals may have high proportions of seagrass in their diets (Burkholder et al. 2011). Therefore, I might expect turtles to have minimal impacts on seagrass communities, even in edge microhabitats where they are concentrated by tiger shark predation risk (Heithaus et al. 2007a). My exclusion experiments, however, suggest that turtles are at least partially responsible for seagrass removal. A halo of grazed seagrass extended into exclosure cages that is consistent with turtles reaching their heads through the mesh to graze grasses they could access (Figure 8).

Together my results suggest that tiger sharks could induce a behavior-mediated trophic cascade in an intact seagrass ecosystem whereby the presence of tiger shark concentrates herbivory by large grazers in edge microhabitats and limits their impacts in interior areas. Predation sensitive habitat shifts likely promote spatial heterogeneity in seagrass community structure and biomass. While the potential importance of such BMTCs has been well-established in small scale experiments in marine, freshwater, and terrestrial settings (Power 1990, Carpenter and Kitchell 1993, Brett and Goldman 1996, Pace et al. 1999, Schmitz et al. 2000, Halaj and Wise 2001, Estes et al. 2004), this study is the first to experimentally investigate their potential to structure marine ecosystems at 
large spatial and temporal scales and in ecosystems featuring intact populations of largebodied predators and herbivores. It seems clear that the potential importance of risk effects in large-scale marine ecosystems must be included in conservation and management planning and in setting restoration targets. Indeed, my results suggest that if megagrazers were released from predation risk entirely, there could be considerable shifts in the seagrass community structure, biomass, and ecosystem services in Shark Bay facilitated by potentially lower grazing pressure along bank edge communities and increased herbivory in interior habitats. Results from more heavily impacted ecosystems support this hypothesis. In Bermuda, recent management strategies have resulted in increasing green turtle populations (Chaloupka et al. 2008) in the presence of reduced tiger shark populations in the region (Baum et al. 2003). The increase in turtle populations appears to have led to increased herbivory and collapses in seagrass biomass (Fourqurean et al. 2010). Similar results have been documented in the Lakshadweep Islands, Indian Ocean with a gradient of turtle density and grazing pressure across a lagoon resulting in decreased shoot density, leaf width, leaf area, and above ground biomass at heavily grazed sites. The grazing pressure gradient also lead to an apparent shift in the seagrass community from a co-dominate bed of Comitas rotundata and Thalassia hemprichii before turtle populations increased to an almost monospecific bed of C. rotundata currently found in areas of high grazing pressure (Lal et al. 2010).

My results have important implications for our understanding of community dynamics in general. Indeed, the responses of megagrazers to predators in Shark Bay are akin to those of herbivores in numerous terrestrial and aquatic ecosystems (Heithaus et al. 2008, 2009). The putative BMTC in Shark Bay similarly mirrors those induced by 
wolves in Yellowstone (Ripple and Betscha 2004, 2007) and spiders in old-field communities (Schmitz 2006). Recently, however, it has been suggested that roving predators may induce only weak risk effects and be less likely to trigger BMTCs than sitin-wait predators (Schmitz 2005, 2008) because roving predators have a risk signature that is more spatially diffuse (i.e., less predictable by potential prey). The variation in hunting mode to trigger BMTC's is supported by data from mesocosm experiments with spiders as top predators and grasshoppers as mesoconsumers (Schmitz 2008; Schmitz 2009). Kauffman et al. (2010) extended this argument, suggesting that even large-bodied roving predators would be unlikely to initiate BMTC and suggested that, in fact, wolves in Yellowstone (a roving predator) did not initiate a BMTC (but see response by Betshca and Ripple 2011).

Because many top vertebrate predators, especially in coastal ecosystems, are roving predators with diffuse risk signatures it is important to determine whether they are less likely than sit-and-wait predators to initiate behavior mediated trophic cascades. Heithaus et al. (2009) suggested that roving predators should, theoretically, be capable of inducing strong risk effects and BMTC if prey operate at spatial scales with heterogeneous landscapes that allow them to minimize encounter rates or conditional probabilities of capture through behavioral adjustments (e.g., spatial shifts). Importantly, many mesocosm experiments have been conducted in relatively homogeneous landscapes. For example, Schmitz (2008) examined the effect of hunting mode on predation risk to grasshopper prey of roving predatory spiders that occupy the midcanopy and sit-and-wait predatory spiders that use the upper canopy. Prey moving across larger, heterogeneous landscapes - like sea turtles and dugongs in Shark Bay - have more 
options to shift into habitats that predictably reduce encounter rates or probability of capture in encounter situations. The results of previous studies in Shark Bay provide evidence for direct risk effects of roving tiger sharks on large-bodied grazers and other taxa and the present experimental study offers evidence that these shifts have cascading impacts on seagrass community structure and nutrient dynamics. Future studies are needed to understand the contexts and pathways in which roving predators are more or less likely to induce BMTC and further investigate the pathways through which tiger sharks, and other top marine predators, might indirectly structure coastal marine communities and the strength of these effects.

\section{Acknowledgments}

I thank the Monkey Mia Dolphin Resort for providing lodging and logistical support. Special thanks to Kirk Gastrich, Rachel Decker, and an army of dedicated field assistants for countless hours helping to maintain and sample exclosure cages. Funding for this project was provided by National Science Foundation grants OCE0526065 and OCE0745606 to M. Heithaus, Florida International University, and FIU Dissertation Evidence Acquisition Fellowship and an FIU Dissertation Year Fellowship to D. Burkholder. I thank Jopalo Boats, Bombadier Recreation Products, Humminbird, The Airline, and Submersible Systems for significant donations in the form of discounts on boats and equipment. Research was conducted under DEC permit numbers: CE002300, SW012509, CE001685 and subsequent annual renewals. 


\section{Literature Cited}

Aragones, L.V. and H. Marsh. 2000. Impact of dugong grazing and turtle cropping on tropical seagrass communities. Pacific Conservation Biology. 5: 277-288.

Aragones, L.V., I.R. Lawler, W.J. Foley, and H. Marsh. 2006. Dugong grazing and turtle cropping: Grazing optimization in tropical seagrass systems? Oecologia 149(4): 635-647.

Armitage, A.R., and Fourqurean, J.W. 2006. The short-term influence of herbivory near patch reefs varies between seagrass species. Journal of Experimental Marine Biology and Ecology 339: 65-74.

Baum, J.K. and R.A. Myers. 2004. Shifting baselines and the decline of pelagic sharks in the Gulf of Mexico. Ecology Letters 7: 135-145.

Baum, J.K. R.A. Myers, D.G. Kehler, B. Worm, S.J. Harley, and P.A. Doherty. 2003. Collapse and conservation of shark populations in the Northwest Atlantic. Science 299 (5605): 389-392.

Bjorndal, K.A. 1980. Nutritional and grazing behavior of the green sea turtle Chelonia mydas. Marine Biology 56: 147-154.

Bjorndal, K.A. 1997. Foraging ecology and nutrition of sea turtles. In The biology of sea turtles (eds. P. L. Lutz \& J. A. Musick), pp. 199-231. Boca Raton: CRC Press.

Beschta, R.L., and W.J. Ripple. 2011. Are wolves saving Yellowstone's aspen? A landscape-level test of a behaviorally mediated trophic cascade-comment. Ecology. doi:10.1890/11-0063.1.

Brett, M.T., and C.R. Goldman. 1996. A meta-analysis of the freshwater trophic cascade. Proceedings of the National Academy of Sciences, USA 93: 7723-7726.

Burkholder, D.A., J.W. Fourqurean, and M.R. Heithaus. In press a. Spatial pattern in seagrass stoichiometry indicates both N-limited and P-limited regions of an iconic P-limited subtropical bay. Marine Ecology Progress Series DOI: $10.3354 /$ meps 10042

Burkholder, D.A., M.R. Heithaus, and J.A. Fourqurean. In press b. Feeding preferences of herbivores in a relatively pristine subtropical seagrass ecosystem. Marine and Freshwater Research. In press.

Burkholder, D., M.R. Heithaus, J. Thomson, and J.W. Fourqurean. 2011. Diversity in trophic interactions of green sea turtles (Chelonia mydas) on a relatively pristine coastal foraging ground. Marine Ecology Progress Series 439: 277-293. 
Carpenter, S.R. and J.F. Kitchell. 1993. The trophic cascade in lakes. Cambridge University Press, Cambridge.

Chaloupka, M., K.A. Bjorndal, G.H. Balazs, A.B. Bolten, L.M. Ehrhart, C.J. Limpus, H. Suganuma, S. Troëng, and M. Yamaguchi. 2008. Encouraging outlook for recovery of a once severely exploited marine megaherbivore. Global Ecology and Biogeography 17: 297-304.

Creel, S. 2011. Toward a predictive theory of risk effects: hypotheses for prey attributes and compensatory mortality. Ecology 92:2190-2195.

Creel, S. and D, Christianson. 2008. Relationships between direct predation and risk effects. Trends in Ecology and Evolution 23: 194-201.

Creel S,J. Winnie Jr., B. Maxwell, K. Hamlin, and M. Creel. 2005. Elk alter habitat selection as an antipredator response to wolves. Ecology 86: 3387-3397.

de Iongh, H.H., B.J. Wenno, and E. Meelis. 1995. Seagrass distribution and seasonal biomass changes in relation to dugong grazing in the Moluccas, East Indonesia. Aquatic Botany 50: 1-19.

Duarte, C.M. 1991. Allometric scaling of seagrass form and productivity. Marine Ecology Progress Series 77: 289-300

Duarte, C.M., N. Marbà, E. Gacia, J.W. Fourqurean, J. Beggins, C. Barrón, and E.T. Apostolaki. 2010. Seagrass community metabolism: Assessing the carbon sink capacity of seagrass meadows, Global Biogeochem. Cycles, 24, GB4032, doi:10.1029/2010GB003793.

Estes, J.A., Danner, E.M., Doak, D.F., Konar, B., Springer, A.M., Tinker, M.T., and T.M. Williams. 2004. Complex trophic interactions in kelp forest ecosystems. Bulletin of Marine Science 74 (3): 621-638.

Estes J.A., J. Terborgh, J.S. Brashares, M.E. Power, J. Berger, W.J. Bond, S.R. Carpenter, T.E. Essington, R.D. Holt, J.B.C. Jackson, R.J. Marquis, L. Oksanen, T. Oksanen, R.T. Paine, E.K. Pikitch, W.J. Ripple, S.A. Sandin, M. Scheffer, T.W. Schoener, J.B. Shurin, A.R.E Sinclair, M.E. Soulé, R. Virtanen, and D.A. Wardle. 2011. Trophic downgrading of planet earth. Science 333 (6040): 301306.

Fortin D., H.L. Beyer, M.S. Boyce, D.W. Smith, T. Duchesne, and J.S. Mao. 2005. Wolves influence elk movements: behavior shapes a trophic cascade in Yellowstone National Park. Ecology 86: 1320-30. 
Fourqurean, J.W., C.M. Duarte, H. Kennedy, N. Marba, M. Holmer, M.A. Mateo, E.T. Apostolaki, G.A. Kendrick, D. Krause-Jensen, K.J. McGlathery, and O. Serrano. 2012. Seagrass ecosystems as a globally significant carbon stock. Nature Geoscience 5: 505-509.

Fourqurean, J.W., S. Manuel, K.A. Coates, W.J. Kenworthy and S.R. Smith. 2010. Effects of excluding sea turtle herbivores from a seagrass bed: overgrazing may have led to loss of seagrass meadows in Bermuda. Marine Ecology Progress Series 419: 223-232

Fourqurean, J.W., J.C. Zieman, and G.V.N. Powell. 1992. Phosphorus limitation of primary production in Florida Bay: Evidence from C:N:P ratios of the dominant seagrass Thalassia testudinum. Limnology and Oceanography 37: 162-171.

Fry, B., Macko, S.A., and J.C. Zieman. 1987. Review of stable isotopic investigations of food webs in seagrass meadows. In 'Proceedings of the symposium on subtropical-tropical seagrasses of the southeastern United States. Florida Marine Research Publications, No. 42. (Eds M. J. Durako, R. C. Phillips and R. R. Lewis, III.) pp. 189-209. Florida Department of Natural Resources: St. Petersburg.

Halaj, J. and D.H. Wise. 2001. Terrestrial trophic cascades: How much do they trickle? American Naturalist 157: 262-281.

Heck, K.L. Jr., R.J. Orth and C.G. Hays. 2003. Critical evaluation of the nursery role hypothesis for seagrass meadows. Marine Ecology Progress Series. 253:123-136.

Heck, K.L., Valentine, J.F. 2006. Plant-herbivore interactions in seagrass meadows. Journal of Experimental Marine Biology and Ecology 330: 420-436

Heck, K.L., and J.F. Valentine. 2007. The primacy of top-down effects in shallow benthic ecosystems. Estuaries and Coasts 30: 371-381.

Heithaus, M.R. 2004. Fish communities of seagrass meadows and associated habitats in Shark Bay, Western Australia. Bulletin of Marine Science 75: 79-99

Heithaus, M.R., Frid, A., Wirsing, A., Bejder, L., and L.M. Dill. 2005. The biology of green and loggerhead turtles under risk from tiger sharks at a foraging ground. Marine Ecology Progress Series 288: 285-294.

Heithaus, M.R., A. Frid, A.J. Wirsing, L.M. Dill, J. Fourqurean, D. Burkholder, J. Thomson, and L. Bejder. 2007a. State-dependent risk-taking by green sea turtles mediates top-down effects of tiger shark intimidation in a marine ecosystem. Journal of Animal Ecology 76: 837-844. 
Heithaus, M.R., A.J. Wirsing, A. Frid, and L.M. Dill. 2007b. Species interactions and marine conservation: Lessons from an undisturbed ecosystem. Israel Journal of Ecology and Evolution 53: 355-370.

Heithaus, M.R., A. Frid, A.J. Wirsing, and B. Worm. 2008. Predicting ecological consequences of marine top predator declines. Trends in Ecology and Evolution 23: $202-210$.

Heithaus, M.R., A.J. Wirsing, D. Burkholder, J. Thomson, and L.M. Dill. 2009. Towards a predictive framework for predator risk effects: the interaction of landscape features and prey escape tactics. Journal of Animal Ecology. 78: 556562.

Heithaus, M.R., A.J. Wirsing, and L.M. Dill. In press. The ecological importance of intact top predator populations: a synthesis of fifteen years of research in a seagrass ecosystem. Marine and Freshwater Research. In press.

Hernández, L. and J.W. Laundré. 2005. Foraging in the landscape of fear and its implications for habitat use and diet quality of elk and bison. Wildlife Biology 11: $215-20$

Jackson, J.B.C. 1997. Reefs since Columbus. Coral Reefs 16: 523-532.

Jackson, J.B.C., M.X. Kirby, W.H. Berger, K.A. Bjorndal, L.W. Botsford, B.J. Borque, R.H. Bradbury, R. Cooke, J. Erlandson, J.A. Estes, T.P. Hughes, S. Kidwell, C.B. Lange, H.S. Lenihan, J.M. Pandolfi, C.H. Peterson, R.S. Steneck, M.J. Tegner, and R.R. Warner, 2001. Historical overfishing and the recent collapse of coastal ecosystems. Science 146, 629-638.

Kauffman M.J., Brodie J.F. and E.S. Jules. 2010. Are wolves saving Yellowstone's aspen? A landscape-level test of a behaviorally mediated trophic cascade. Ecology, 91, 2742-2755.

Kuiper-Linley M., Johnson C.R., and J.M. Lanyon. 2007. Effects of simulated green turtle grazing on seagrass abundance, growth and nutritional status in Moreton Bay, south-east Queensland, Australia. Marine and Freshwater Research 58: 492503.

Lal A., R. Arthur, N. Marba, A.W.T. Lill, and T. Alcoverro. 2010. Implications of conserving an ecosystem modifier: Increasing green turtle (Chelonia mydas) densities substantially alters seagrass meadows. Biological Conservation 143: 2730-2738. 
Masini, R.J., P.K Anderson, and A.J. McComb. 2001. A Halodule-dominated community in a subtropical embayment: physical environment, productivity, biomass, and impact of dugong grazing. Aquatic Botany 71: 179-197.

Marsh, H., G. De'ath, N. Gribble, and B. Lane. 2005. Historical marine population estimates, triggers or targets for conservation? The dugong case study. Ecological Applications 15: 481-492.

Moran, K.L., and K.A. Bjorndal. 2005. Simulated green turtle grazing affects structure and productivity of seagrass pastures. Marine Ecology Progress Series 305: 235-247.

Murdoch, T.J.T., A.F. Glasspool, M. Outerbridge, J. Ward, S. Manuel, J. Gray, A. Nash, K. A. Coates, J. Pitt, J.W. Fourqurean, P.A. Barnes, M. Vierros., K. Holzer, and S.R. Smith. 2007. Large-scale decline of offshore seagrass meadows in Bermuda. Marine Ecology Progress Series 339:123-130.

Nakaoka, M., Mukai, H., Chunhabundit, S., 2002. Impacts of dugong foraging on benthic animal communities in a Thailand seagrass bed. Ecological Research 17, 625-638.

Orth, R.J., T.J.B. Carruthers, W.C. Dennison, C.M. Duarte, J.W. Fourqurean, K.L. Heck Jr., A.R. Hughes, G.A. Kendrick, W.J.Kenworthy, S. Olyarnik, F.T. Short, M. Waycott, and S.L. Williams. 2006. A global crisis for seagrass ecosystems. BioScience 56 (12): 987-996.

Pace, M.L., J.J. Cole, S.R. Carpenter, and J.F. Kitchell. 1999. Trophic cascades revealed in diverse systems. Trends in Ecology and Evolution 14: 483-488.

Power, M.E. 1990. Effects of fish in river food webs. Science 250: 811-814.

Preen, A.R. 1995. Impacts of dugong foraging on seagrass habitats: observational and experimental evidence for cultivation grazing. Marine Ecology Progress Series 124: 201-213.

Preen, A.R., Marsh, H.D., Lawler, I.R., Prince, R.I., and R. Shepherd. 1997. Distribution and abundance of dugongs, turtles, dolphins and other megafauna in Shark Bay, Ningaloo Reef and Exmouth Gulf, Western Australia. Wildlife Research 24(2): 185-208.

Preisser, E.L., Bolnick, D.I., and M.F. Benard. 2005. Scared to death? The effects of intimidation and consumption in predator-prey interactions. Ecology 86:501-509

Ripple W.J., and R.L. Beschta. 2004. Wolves and the ecology of fear: can predation risk structure ecosystems? BioScience 54: 755-66. 
Ripple, W.J., and R.L. Beschta. 2007. Restoring Yellowstone's aspen with wolves. Biological Conservation 138: 514-519.

Schmitz, O.J. 2005. Behavior of predators and prey and links with population-level processes. In: Ecology of Predator-Prey Interactions (Eds. P. Barbosa, \& I. Castellanos), pp. 256-278. Oxford: Oxford University Press.

Schmitz, O.J. 2006. Predators have large effects on ecosystem properties by changing plant diversity, not plant biomass. Ecology 87(6): 1432-1437.

Schmitz O.J. 2008. Effects of predator hunting mode on grassland ecosystem function. Science, 319, 952-954.

Schmitz O.J. 2009. Effects of predator functional diversity on grassland ecosystem function. Ecology, 90, 2339-2345.

Schmitz O.J., Beckerman, A.P., and K.M. O’Brien. 1997. Behaviorally mediated trophic cascades: Effects of predation risk on food web interactions. Ecology 78(5): 13881399.

Schmitz O.J. and K.B. Suttle. 2001. Effects of top predator species on direct and indirect interactions in a food web. Ecology 82(7): 2072-2081.

Schmitz, O.J., Hamback, P.A., and A.P. Beckerman. 2000. Trophic cascades in terrestrial systems: A review of the effects of carnivore removal on plants. American Naturalist. 155: 141-153.

Shurin J.B, and E.W. Seabloom. 2005. The strength of trophic cascades across ecosystems: Predictions from allometry and energetics. Journal of Animal Ecology 74(6): 1029-1038.

Thayer, G.W., Bjorndal, K.A., Ogden, J.C., Williams, S.L., and J.C. Zieman. 1984. Role of larger herbivores in seagrass communities. Estuaries 7:351-376

Thayer, G.W., and D.W. Engel. 1982. Evidence for short circuiting of the detritus cycle of seagrass beds by the green turtle Chelonia mydas. J Exp Mar Biol Ecol 62 (2): $173-183$.

Wabnitz C.C.C., Balazs G., Beavers S., Bjorndal K.A., Bolten A.B., Christensen V., Hargrove S., and D. Pauly. 2010. Ecosystem structure and processes at Kaloko Honokohau, focusing on the role of herbivores, including the green sea turtle Chelonia mydas, in reef resilience. Marine Ecology Progress Series 420: 27-44. 
Walker, D.I., Kendrick, G.A., and A.J. McComb. 1988. The distribution of seagrass species in Shark Bay, Western Australia, with notes on their ecology. Aquatic Botany 30, 305-317.

Waycott, M., Duarte, C.M., Carruthers, T.J.B., Orth, R.J., Dennison, W.C., Olyarnik, S., Calladine, A., Fourqurean, J.W., Heck Jr. K.L., Hughes, A.R., Kendrick, G.A., Kenworthy, W.J., Short F.T., and S.L. Williams. 2009. Accelerating loss of seagrasses across the globe threatens coastal ecosystems. Proceedings of the National Academy of Sciences. USA 106(30): 12377-12381

Werner, E.E. and S.D. Peacor. 2003. A review of trait-mediated indirect interactions in ecological communities. Ecology 84: 1083-1100.

Williams, S. L. 1988. Thalassia testudinum productivity and grazing by green turtles in a highly disturbed seagrass bed. Marine Biology 98: 447-455.

Wirsing A.J., Cameron K.E. \& M.R. Heithaus. 2010. Spatial responses to predators vary with prey escape mode. Animal Behaviour, 79, 531-537.

Wirsing, A.J., M.R. Heithaus, and L.M. Dill. 2007a. Fear factor: Do dugongs (Dugong dugon) trade food for safety from tiger sharks (Galeocerdo cuvier)? Oecologia 153: 1031-1040.

Wirsing, A.J., M.R. Heithaus, and L.M. Dill. 2007b. Living on the edge: dugongs prefer to forage in microhabitats that allow escape from rather than avoidance of predators. Animal Behavior 74: 93-101.

Wirsing, A.J., M.R. Heithaus, and L.M. Dill. 2007c. Can you dig it? Use of excavation, a risky foraging tactic, by dugongs is sensitive to predation danger. Animal Behavior 74: 1085-1091.

Wirsing A.J., Heithaus M.R., and L.M. Dill. 2007d. Can measures of prey availability improve our ability to predict the abundance of large marine predators? Oecologia 153: 563-568.

Wirsing, A.J., M.R. Heithaus, and L.M. Dill. 2011. Predator-induced modifications to diving behavior vary with foraging mode. Oikos 120: 1005-1012.

Zieman, J.C., R.L. Iverson, and J.C. Ogden. 1984. Herbivory effects on Thalassia testudinum leaf growth and nitrogen content. Marine Ecology Progress Series. 15: 151-158. 
Table 1: Factors influencing the density of seagrasses in edge microhabitats.

\begin{tabular}{llll}
\hline & df & $\mathbf{F}$ & $\mathbf{P}$ \\
\hline Cymodocea angustata & & & \\
Time & 1,39 & 2.75 & $\mathbf{0 . 0 0 9}$ \\
Treatment & 1,39 & 3.26 & $\mathbf{0 . 0 0 2}$ \\
Time x treatment & 1,39 & 2.05 & $\mathbf{0 . 0 4 7}$ \\
Halodule uninervis & 1,39 & & \\
Time & 1,39 & 3.15 & $\mathbf{0 . 0 0 4}$ \\
Treatment & 1,39 & 3.07 & $\mathbf{0 . 0 0 5}$ \\
Time x treatment & & & \\
Halophila ovalis & 1,39 & 1.11 & 0.27 \\
Time & 1,39 & 1.79 & 0.08 \\
Treatment & 1,39 & 0.59 & 0.56 \\
Time x treatment & & & \\
\hline
\end{tabular}


Table 2: Statistical comparison of nutrient content of three species of fast-growing seagrasses in exclosures and control sites within edge microhabitats.

\begin{tabular}{llllllll}
\hline Species & & \multicolumn{2}{c}{ C:N } & \multicolumn{2}{c}{ C:P } & \multicolumn{2}{c}{ N:P } \\
& df & $\mathrm{F}$ & $\mathrm{P}$ & $\mathrm{F}$ & $\mathrm{P}$ & $\mathrm{F}$ & $\mathrm{P}$ \\
\hline C. angustata & 1,23 & 2.20 & 0.15 & $\mathbf{5 . 5 2}$ & $\mathbf{0 . 0 3}$ & 2.78 & 0.11 \\
H. uninervis & 1,9 & 1.28 & 0.29 & $\mathbf{1 6 . 9 7}$ & $\mathbf{0 . 0 0 3}$ & 4.68 & 0.06 \\
H. ovalis & 1,8 & 2.76 & 0.14 & 0.00 & .98 & 0.57 & 0.48 \\
\hline
\end{tabular}




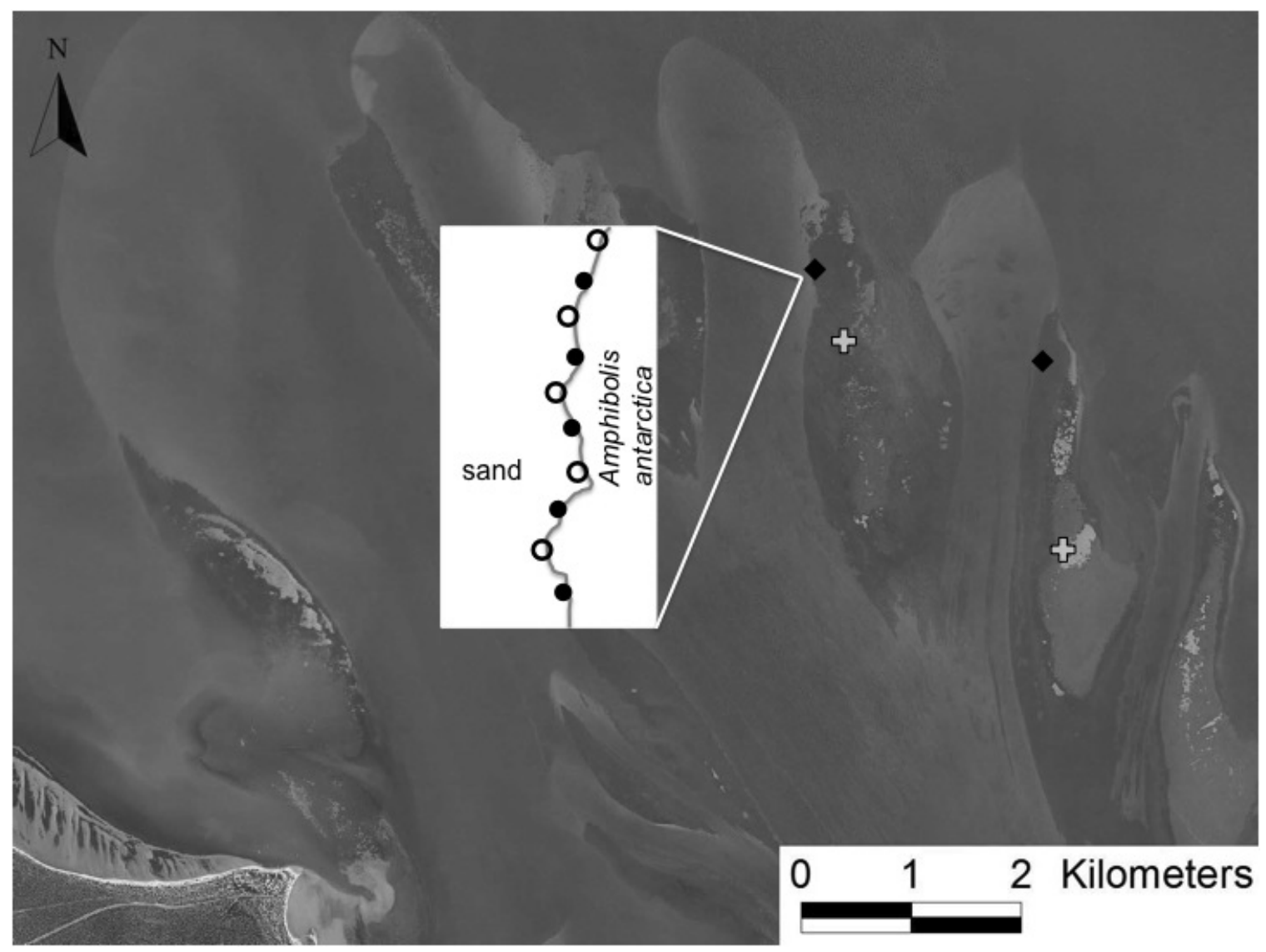

Figure 1. The study was conducted in the Eastern Gulf of Shark Bay, Western Australia

(a). Exclosure and control plots were established on two banks within the long-term study area. The location of "edge" sites are denoted with a black diamond, "interior" sites with gray "+" symbol. Cage sites are denoted with a closed circle. Control sites are open circles. 

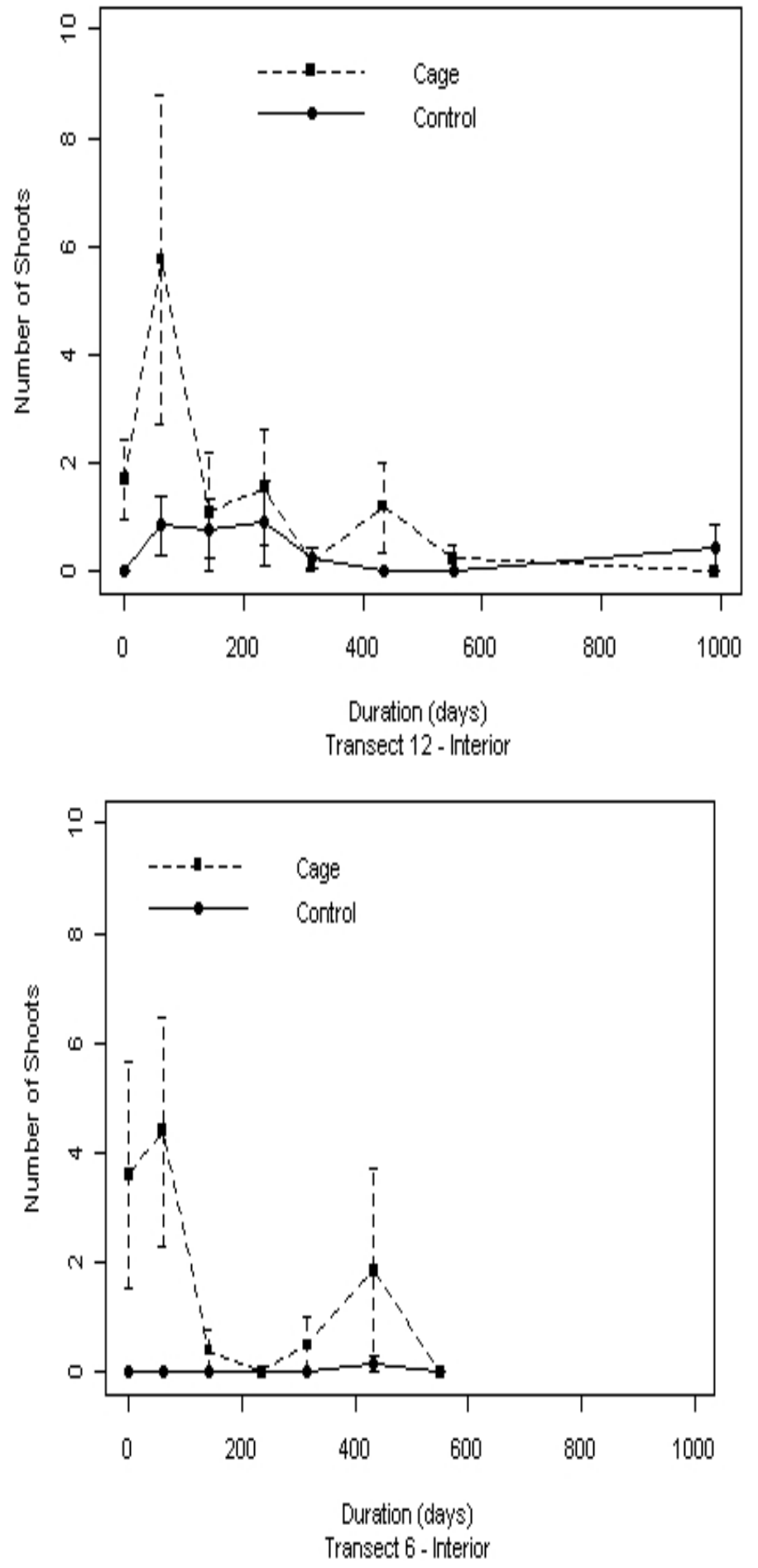

Figure 2. Temporal variation in the densities of Halodule uninervis within interior exclosures and control plots. Error bars represent \pm SE. 


\section{Control}
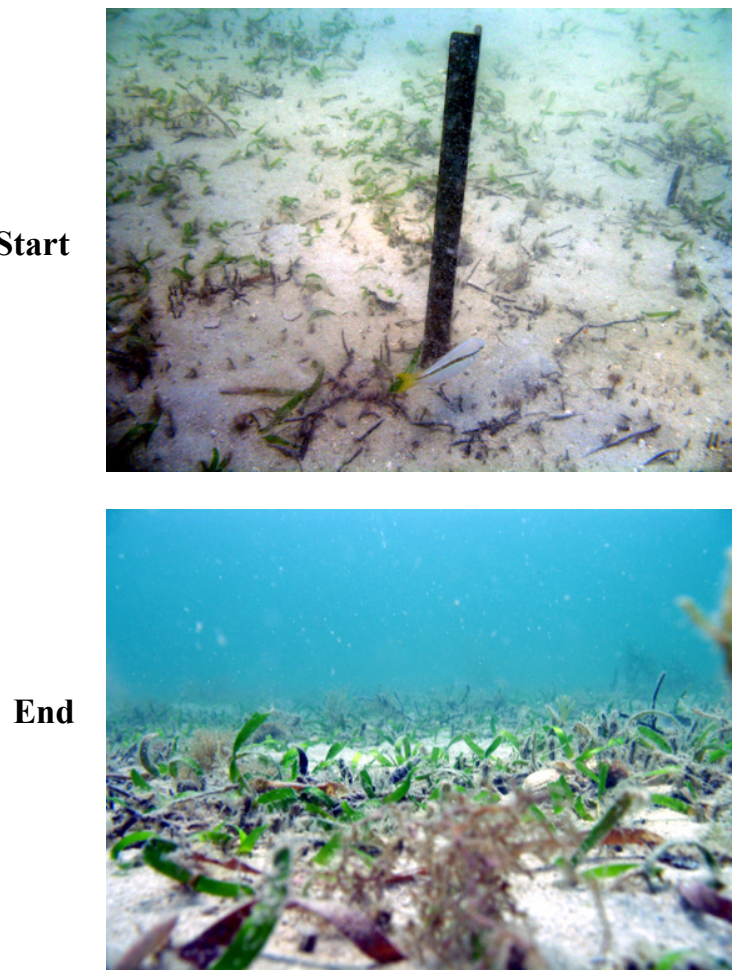

\section{Exclosure}
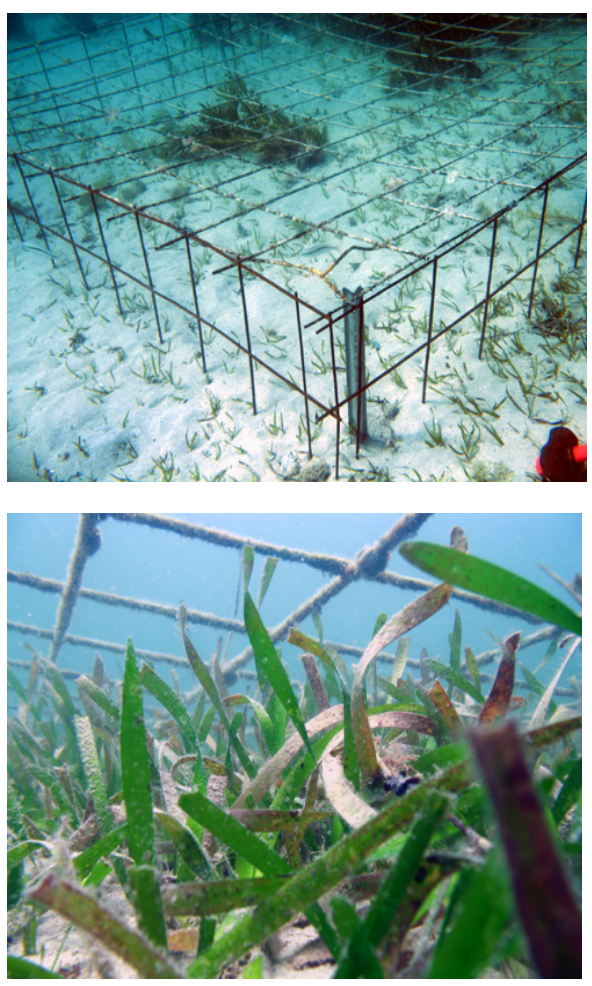

Figure 3: At the initiation of experiments in edge microhabitats, seagrasses were relatively sparse and closely cropped (top). After 600 days, blade heights and densities had increased (below). 


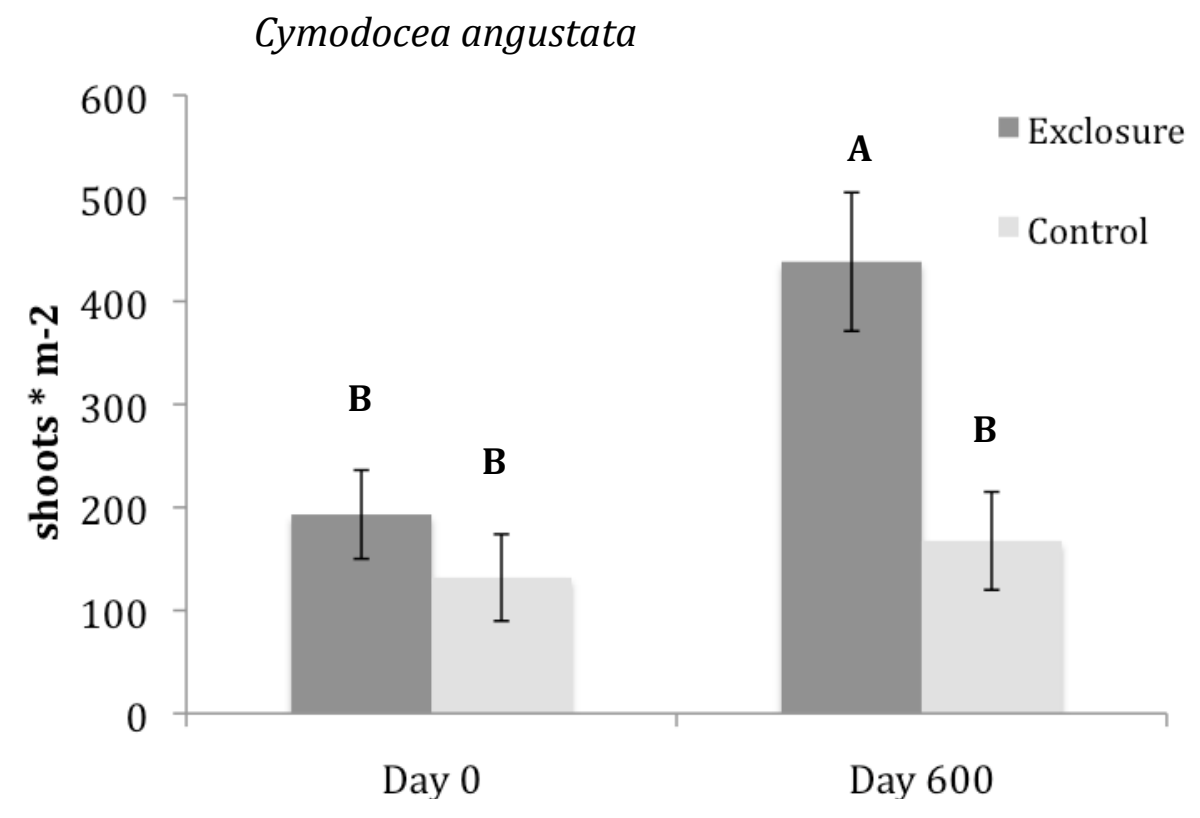

Halodule uninervis

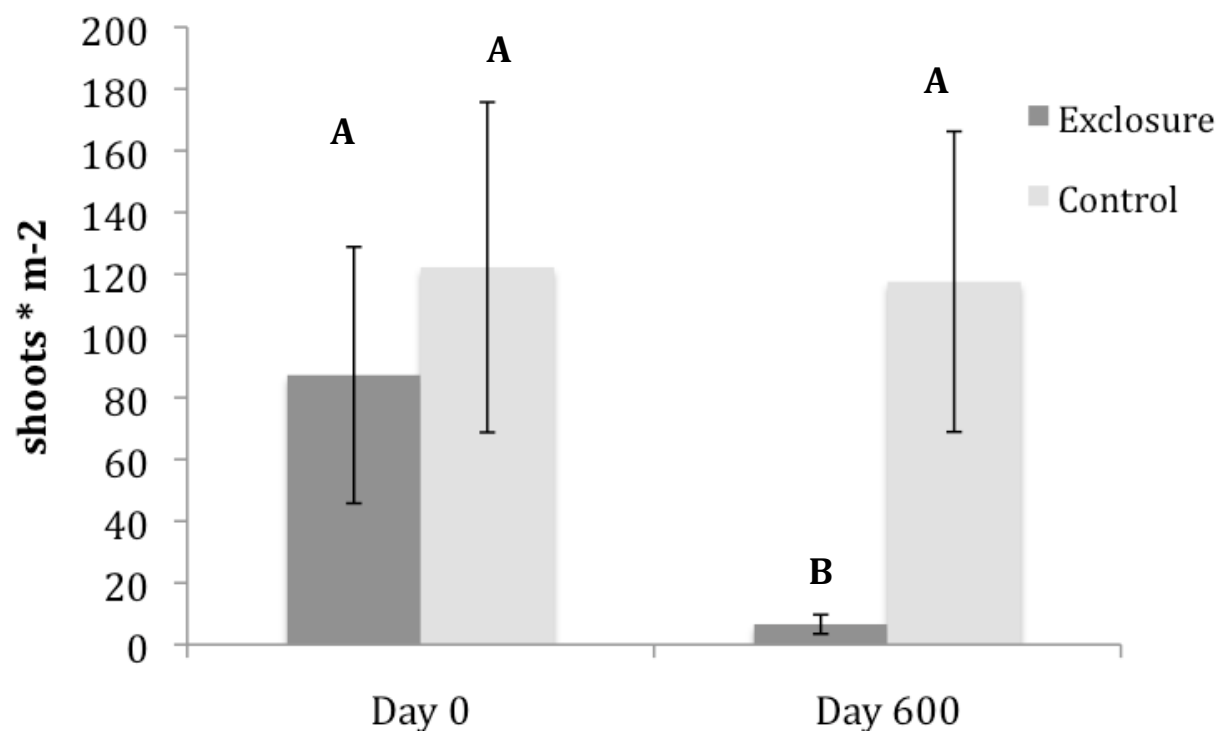

Figure 4: Initial and ending shoot densities of Cymodocea angustata and Halodule uninervis in exclosures and control plots in the edge microhabitat. Bars with different letters are significantly different based on post-hoc Tukey's tests. Error bars represent \pm SE. 


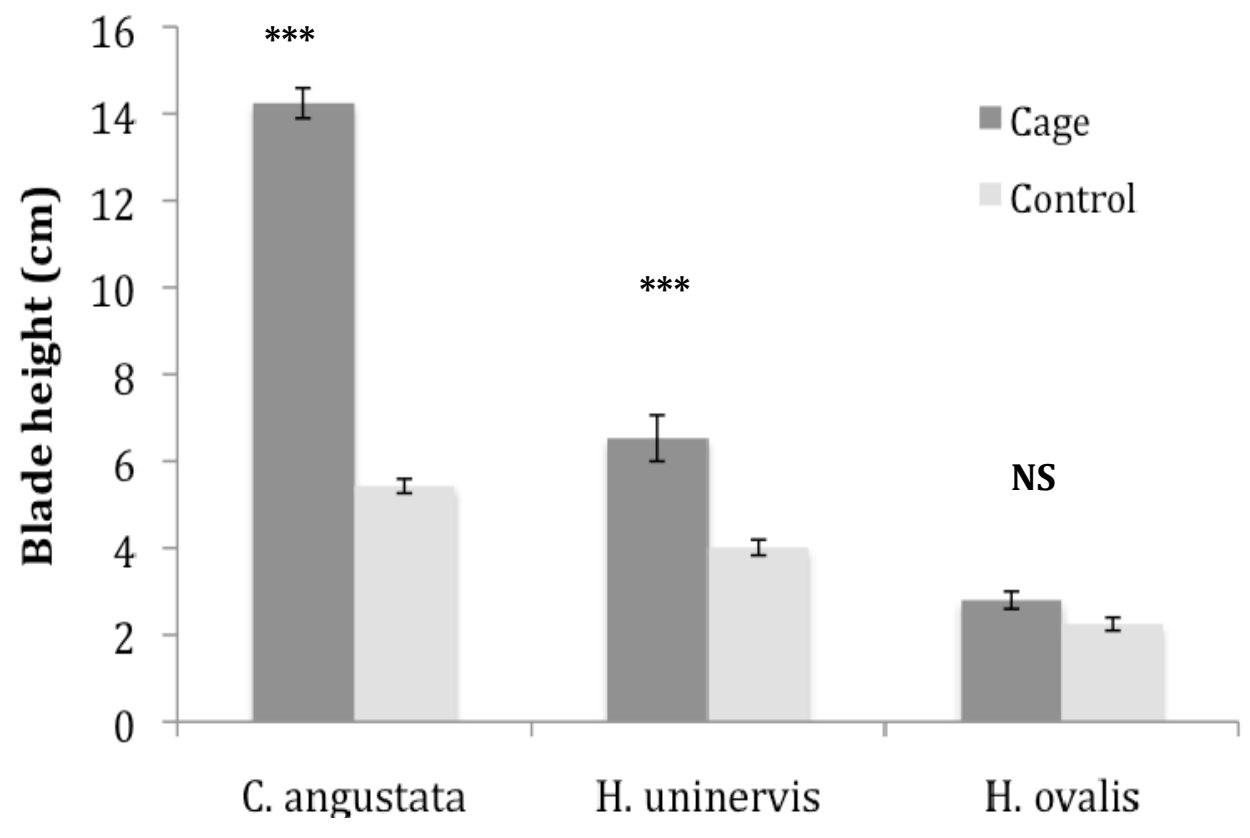

Figure 5: Heights of seagrasses at the conclusion of experiments in the edge microhabitat. Error bars represent \pm SE. t-test $* * * \mathrm{P}<0.0001$; NS $=$ not significant 
a)

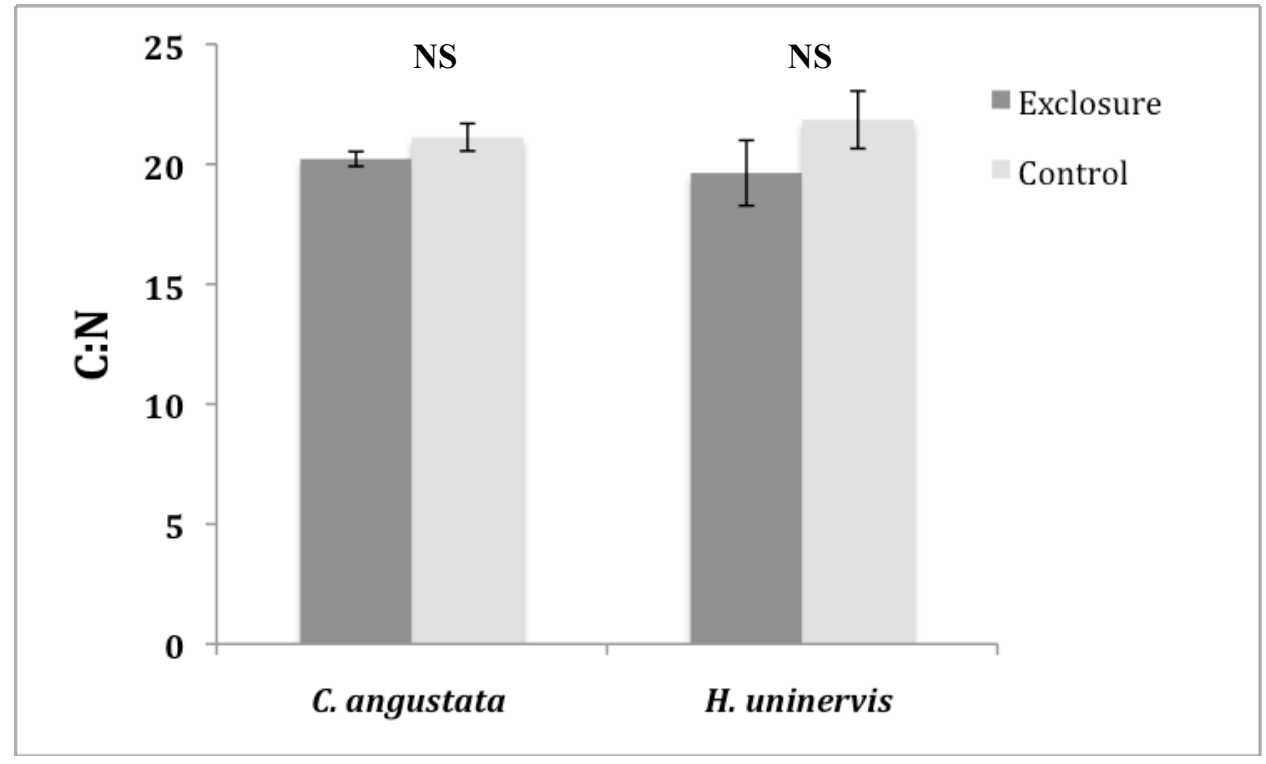

b)

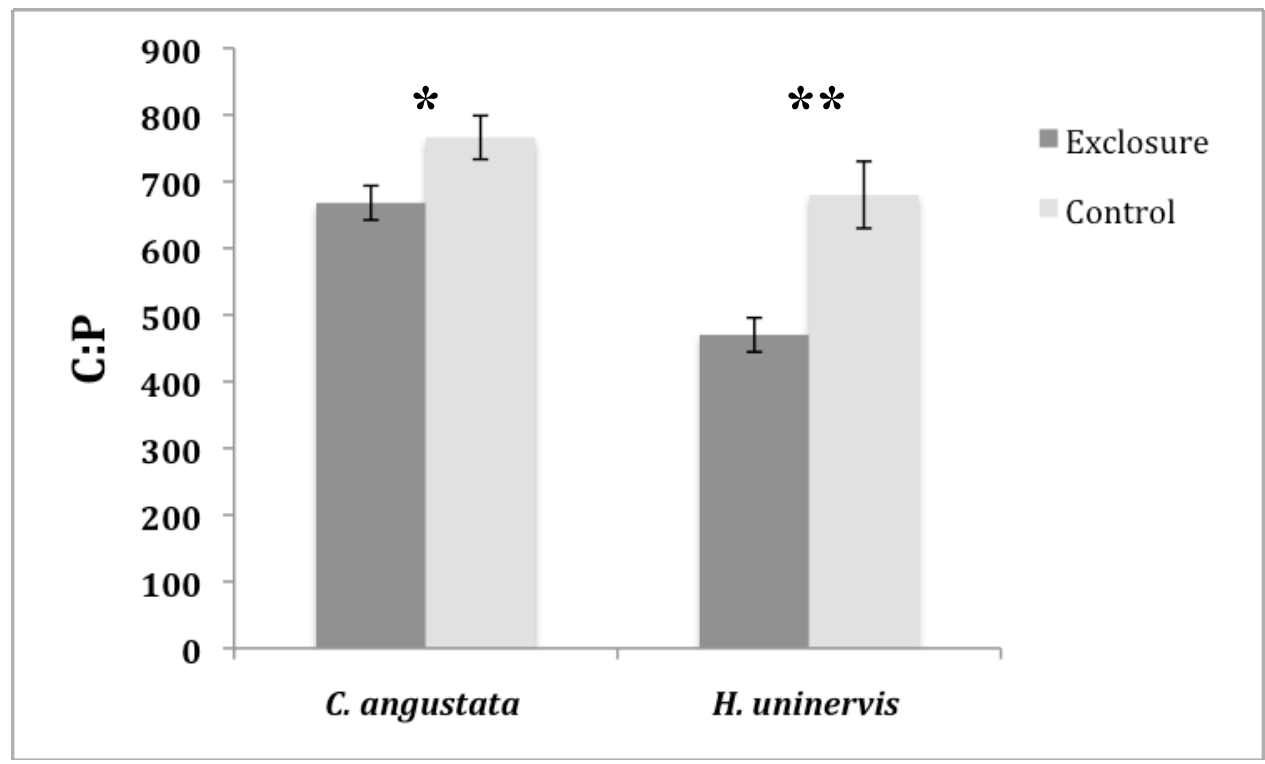

Figure 6: Nutrient content a) $\mathrm{C}: \mathrm{N}$, b) $\mathrm{C}: \mathrm{P}$, c) $\mathrm{N}: \mathrm{P}$ of seagrass blades in exclosures and controls at the conclusion of experiments in the edge microhabitat. Error bars represent \pm SE. t-test $* * * \mathrm{P}<0.001, * * \mathrm{P}<0.01, * \mathrm{P}<0.05$, NS $=$ not significant 
c)

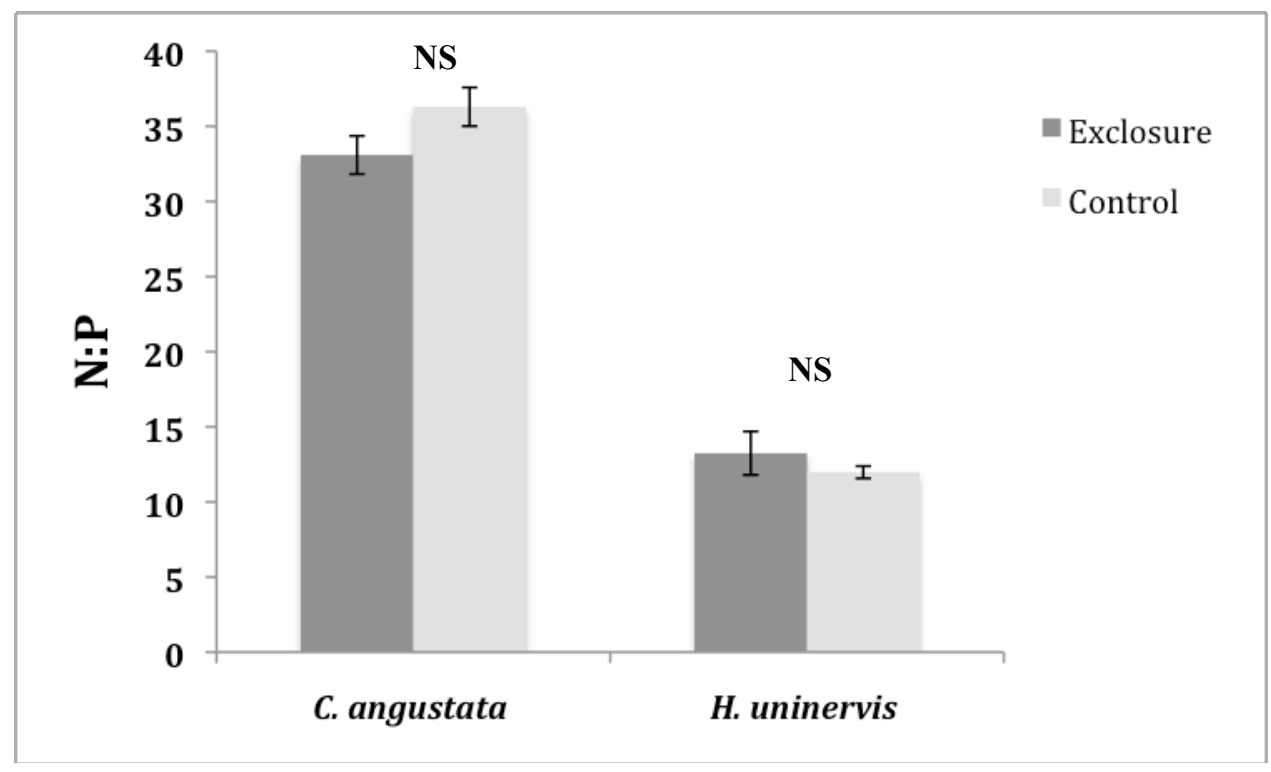

Figure 6(cont.): Nutrient content a) $\mathrm{C}: \mathrm{N}, \mathrm{b}$ ) $\mathrm{C}: \mathrm{P}, \mathrm{c}$ ) N:P of seagrass blades in exclosures and controls at the conclusion of experiments in the edge microhabitat. Error bars represent $\pm \mathrm{SE}$. t-test $* * * \mathrm{P}<0.001, * * \mathrm{P}<0.01,{ }^{*} \mathrm{P}<0.05, \mathrm{NS}=$ not significant 


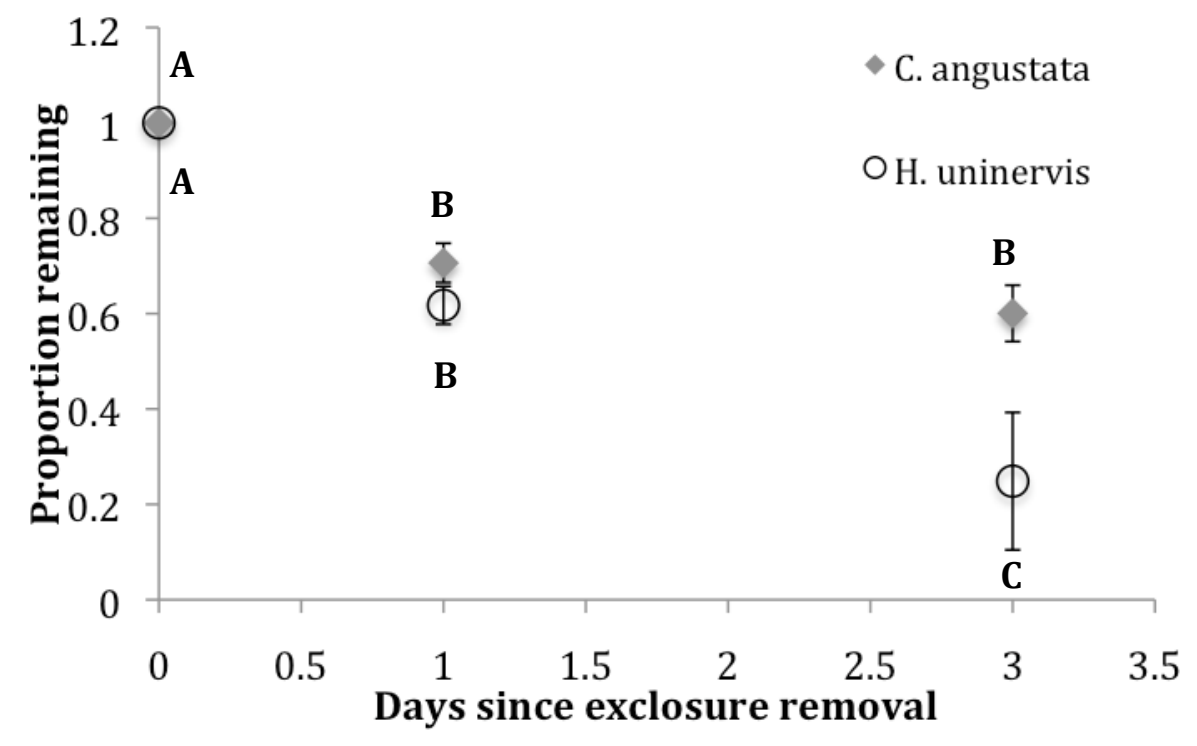

Figure 7. Proportion of remaining C. angustata $(\mathrm{n}=10$ plots $)$ and H. uninervis ( $n=4$ plots) blades remaining after removal of exclosures in the edge microhabitat. Error bars represent \pm SE. Symbols with different letters are significantly different based on Tukey's post-hoc tests. Letters above symbols are $C$. angustata and those below symbols are H. uninervis. 

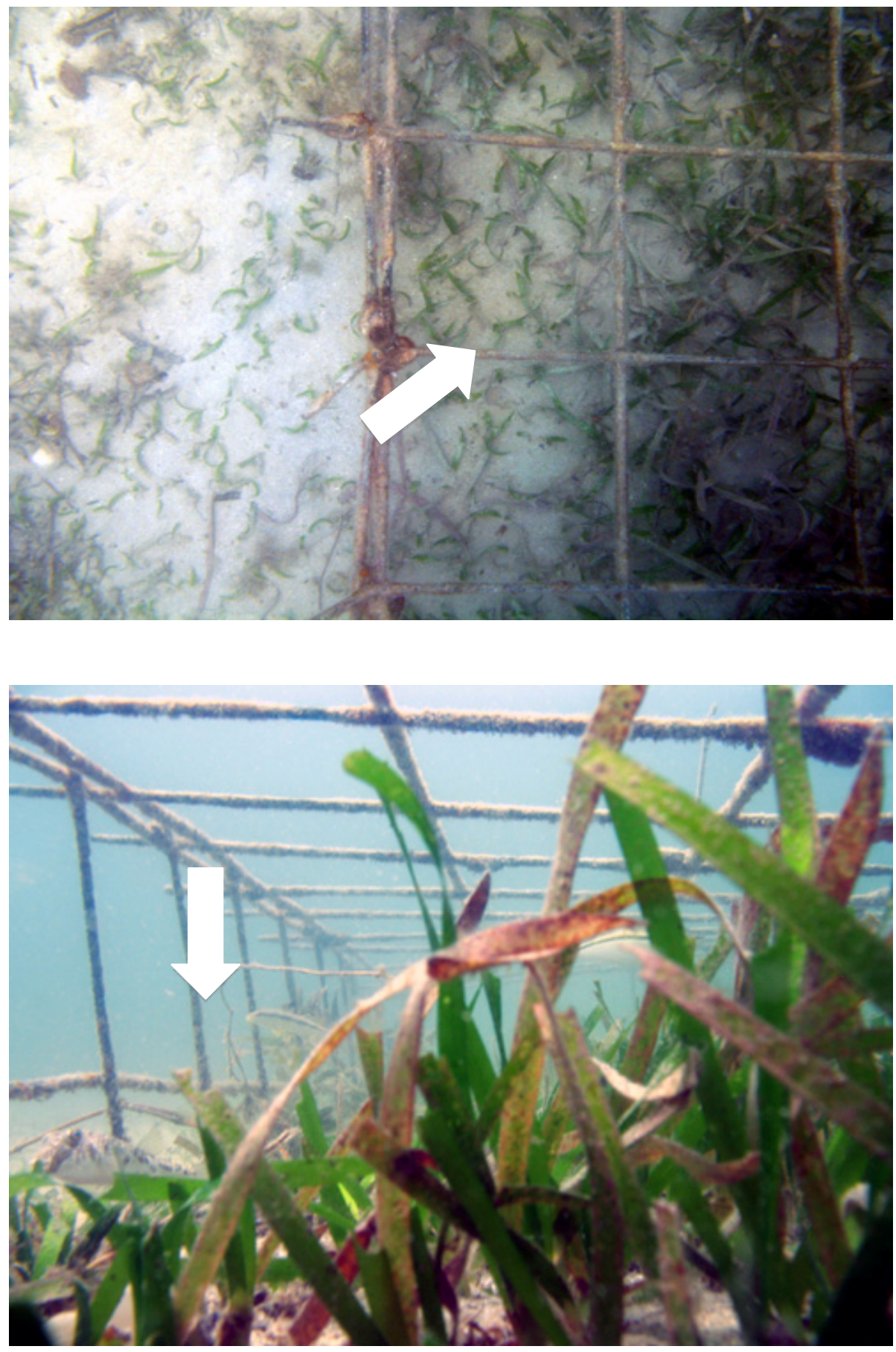

Figure 8. Halos of grazing (white arrows) inside exclosures suggest that green turtles are at least partially responsible for reduced seagrass biomass in edge microhabitats. 
CHAPTER VI

SUMMARY 
In my dissertation I investigated the dynamics of one of the world's last remaining pristine seagrass ecosystems including the potential effects of large bodied herbivores (dugongs and green sea turtles) in structuring a seagrass ecosystem. I also assessed the possibility of a behavior-mediated trophic cascade (BMTC) transmitted from tiger sharks to seagrasses by predation-sensitive habitat use and foraging behavior of megagrazers. In Chapter II, I examined seagrass distribution, seagrass community and nutrient dynamics at a whole-bay scale. In addition I assessed patterns of nutrient limitation in Shark Bay, an iconic phosphorus-limited seagrass system (Smith and Atkinson 1983, Smith 1984, Atkinson 1987). I found a diverse seagrass community comprised of seagrass species of temperate and tropical origin, with some individual sites supporting as many as six different seagrass species. Nutrient content of seagrasses varied across species as well as across the bay. Seagrass stoichiometry indicate broad areas of the bay that appear to be N-limited and P-limited, and areas that are not nutrient limited. Phosphorus-limitation is restricted primarily to areas of the bay that have restricted water exchange with the ocean.

Nutrient content of primary producers can have a large impact on resource selection by herbivores (Mariani and Alcoverro 1999, deIongh et al. 1995, Preen 1995, Moran and Bjorndal 2005, Boyer et al. 2004, Goecker et al. 2005, Armitage and Fourqurean 2006, Burkepile and Hay 2009). In Chapter III, I conducted a forage choice experiment using the commonly occurring seagrass species in my restricted study site. I found that removal rates varied considerably among species with the faster growing seagrass species experiencing higher rates of herbivory that the slower growing more temperate species. At a broad scale, this correlated well with nutrient content of 
seagrasses, but within fast-growing species, removal rates were not closely tied to $\mathrm{N}$ or $\mathrm{P}$ content. Future studies investigating ease of leaf removal and the presence of other compounds that might affect palatability are necessary to better understand herbivore forage selection. Feeding patterns of dugongs in Shark Bay are well-studied (e.g., Wirsing 2007a,b,c), but those of the other megaherbivore in Shark Bay, green turtles, were not. Therefore, in Chapter IV, I used stable isotopic analysis of turtle tissues combined with animal borne video and stomach content analysis to examine the diet of these animals. I found a surprisingly small amount of seagrass tissue being incorporated into the tissues of green turtles. Instead, it appears that most turtles forage more heavily on algae and gelatinous macroplankton. In addition I found a large variation in isotopic carbon ratios in turtle skin tissue suggesting some degree of individual diet specialization within the population.

On the basis of my study and previous studies of foraging behavior of megagrazers and predation-sensitive habitat and microhabitat use by dugongs (Wirsing et al. 2007a,b) and green turtles (Heithaus et al. 2007), I was able to conduct experimental studies in Chapter V, that tested a priori predictions about spatial variation in megagrazer impacts on seagrass community structure, density, and nutrient composition. On the basis of a hypothesized (BMTC) initiated by tiger sharks (Galeocerdo cuvier) and mediated by large grazers, I expected megagrazer impacts to be concentrated along the safer edges of banks and relatively minimal in the middle of banks. I found that there was very low standing stock of tropical seagrass species in the interior of seagrass banks at the initiation of a megagrazer exclosure experiment and, consistent with predictions, there was no significant increase in seagrass density over the course of the 600-day 
experiment. In contrast, excluding megagrazers had large impacts on seagrasses in edge microhabitats with species-specific responses to release from megagrazer foraging pressure. Briefly, Cymodocea angustata showed almost a three-fold increase in shoot densities and a doubling in shoot length in edge habitats when protected from herbivory compared to control plots. However Halodule uninervis showed a marked decrease in shoot density within cage plots over the course of the experiment. Interestingly, the $H$. uninervis that was present in the cages at the end of the experiment had significantly longer shoot lengths than those found in control plots. When combining previous research in Shark Bay examining habitat use and foraging behavior of dugongs and green turtles with experimental evidence of herbivore impact on seagrass communities, it is likely that a behavior-mediated trophic cascade initiated by tiger sharks, and mediated by spatio-temporal variation in habitat use by large grazers may ultimately help to shape the seagrass communities in Shark Bay.

Although green turtles may not rely heavily on seagrass as a food source in Shark Bay at the population level (Burkholder et al. 2011) they still appear to have an impact on seagrass community composition and dynamics. While it is hard to quantify dugong vs. turtle foraging from my exclusion cage design, it is evident from the presence of grazing halos along the inside edges of the cages that green turtles are responsible for at least some of the seagrass removal in the system. These grazing halos, most likely created by turtles extending their necks into the exclusion plots from the sides were found in most cages. As a result of the cage design, this halo effect would not be caused by dugong grazing, and the smaller mesograzers in the system were able to swim in and out of the cages freely. 
The virtual absence of tropical seagrass communities in the interior microhabitats at the beginning and end of the experiment, but with brief outbreaks in some cages suggests that another trophic pathway and/or physical drivers are also important in shaping the overall seagrass community. I speculate, however, that other trophic pathways are important in this system because these tropical seagrass communities are found in other areas with similar depth but different spatial context (i.e., bank accessibility to tiger harks). For example, Halodule uninervis is the dominant seagrass species in the shallow, but expansive, Wooramel delta (Masini et al. 2001). Furthermore, during my studies of herbivore foraging preferences I observed an abundant teleost consuming fast-growing seagrass species. Because this species is part of a four-step trophic pathway from tiger sharks to seagrasses it is possible that this BMTC leads to heavy teleost pressure on fast-growing seagrasses in interior microhabitats. Future work will be required to examine this hypothesis. Such data will help to inform management decisions in seagrass ecosystems, and highlight the importance of both large herbivores and top predators in structuring these important coastal areas. More broadly, the work in this dissertation suggests that roving top predators likely are important in structuring community - and possibly ecosystem - dynamics through non-consumptive pathways. 


\section{LITERATURE CITED}

Armitage AR, Fourqurean JW (2006) The short-term influence of herbivory near patch reefs varies between seagrass species. Journal of Experimental Marine Biology and Ecology 339(1): 65-74

Atkinson MJ (1987) Low phosphorus sediments in a hypersaline marine bay. Estuarine Coastal and Shelf Science 24: 335-347

Boyer KE, Fong P, Armitage AR, Cohen RA (2004) Elevated nutrient content of tropical macroalgae increases rates of herbivory in coral, seagrass, and mangrove habitats. Coral Reefs 23(4): 530-538

Burkepile DE, Hay ME (2009) Nutrient versus herbivore control of macroalgal community development and coral growth on a Caribbean reef. Marine Ecology Progress Series 389: 71-84

Burkholder DA, Heithaus MR, Thomson, JA, Fourqurean JW (2011) Diversity in trophic interactions of green sea turtles Chelonia mydas on a relatively pristine coastal foraging ground. Marine Ecology Progress Series 439: 277-293

de Iongh, H. H., B. J. Wenno, and E. Meelis. 1995. Seagrass distribution and seasonal biomass changes in relation to dugong grazing in the Moluccas, East Indonesia. Aquatic Botany 50: 1-19

Goecker ME, Heck KL, Valentine JF (2005) Effects of nitrogen concentrations in turtlegrass Thalassia testudinum on consumption by the bucktooth parrotfish Sparisona radians. Marine Ecology Progress Series 286: 239-248

Heithaus MR, Frid A, Wirsing AJ, Dill LM, Fourqurean J, Burkholder D, Thomson J, Bejder L (2007) State-dependent risk-taking by green sea turtles mediates topdown effects of tiger shark intimidation in a marine ecosystem. Journal of Animal Ecology 76, 837-844

Mariani S, Alcoverro T (1999) A multiple-choice feeding-preference experiment utilizing seagrasses with a natural population of herbivorous fishes. Marine Ecology Progress Series 189: 295-299

Masini RJ, Anderson PK, McComb AJ (2001) A Halodule-dominated community in a subtropical embayment: physical environment, productivity, biomass, and impact of dugong grazing. Aquatic Botany 71: 179-197 
Moran KL, Bjorndal KA (2005) Simulated green turtle grazing affects structure and productivity of seagrass pastures. Marine Ecology Progress Series. 305: 235-247

Preen AR (1995) Impacts of dugong foraging on seagrass habitats: observational and experimental evidence for cultivation grazing. Marine Ecology Progress Series. 124: $201-213$

Smith SV (1984) Phosphorus versus nitrogen limitation in the marine environment. Limnology and Oceanography 29: 1149-1160

Smith SV, Atkinson MJ (1983) Mass balance of carbon and phosphorus in Shark Bay, Western Australia. Limnol Oceanogr 28: 625-639

Wirsing AJ, Heithaus MR, Dill LM (2007a) Fear factor: Do dugongs (Dugong dugon) trade food for safety from tiger sharks (Galeocerdo cuvier)? Oecologia 153: $1031-1040$

Wirsing AJ, Heithaus MR, Dill LM (2007b) Living on the edge: dugongs prefer to forage in microhabitats that allow escape from rather than avoidance of predators. Animal Behavior 74: 93-101

Wirsing AJ, Heithaus MR, Dill LM (2007c) Can you dig it? Use of excavation, a risky foraging tactic, by dugongs is sensitive to predation danger. Animal Behavior 74: 1085-1091 
VITA

\section{DEREK ANTHONY BURKHOLDER}

Born, Lansing, Michigan

2004

B. A. Biology

Albion College, Albion, Michigan

\section{PUBLICATIONS AND PRESENTATIONS}

Burkholder, D. and M. R. Heithaus. Feeding ecology and habitat use of green sea turtles in a pristine seagrass ecosystem. American Elasmobranch Society Meetings. July, 2009.

Burkholder, D., M. R. Heithaus, C. Layman, and J. Thomson. Foraging ecology and stable isotopic analysis of green sea turtles (Chelonia mydas) in Shark Bay, Western Australia: Are green turtles really herbivores? American Elasmobranch Society Meetings, July 2010.

Burkholder, D., M. R. Heithaus, J. Fourqurean, and A. Wirsing. Top-down control in a relatively pristine seagrass ecosystem. CERF 2011: $21^{\text {st }}$ Biennial Conference of the Coastal and Estuarine Research Federation. Daytona Beach. November, 2011.

Heithaus, M., C. Bessey, D. Burkholder, and J. Fourqurean. Do tiger sharks influence seagrass ecosystems through multiple indirect pathways? World Congress of Herpetology 2012, Vancouver Canada, August 2012.

Burkholder, D., M. R. Heithaus, J. Fourqurean, and A. Wirsing. Top-down control in a relatively pristine seagrass ecosystem. World Congress of Herpetology 2012, Vancouver Canada, August 2012.

Burkholder, D. A., M. R. Heithaus, and J. A. Fourqurean. In press. Feeding preferences of herbivores in a relatively pristine subtropical seagrass ecosystem. Marine and Freshwater Research.

Belicka, L. L., D. A. Burkholder, J. W. Fourqurean, M.R. Heithaus, S. A. Macko and R. Jaffé. In press. Stable isotope and fatty acid biomarkers of seagrass, epiphytic, and algal organic matter to consumers in a nearly pristine seagrass ecosystem. Marine and Freshwater Research.

Burkholder, D. A., J. W. Fourqurean, and M. R. Heithaus. In press. Spatial pattern in seagrass stoichiometry indicates both N-limited and P-limited regions of an iconic P-limited subtropical bay. Marine Ecology Progress Series. DOI:

$10.3354 /$ meps 10042 
Thomson, J. A., M. R. Heithaus, D. A. Burkholder, J. J. Vaudo, A. J. Wirsing, and L. M. Dill. 2012. Site specialists, diet generalists? Isotopic variation, site fidelity and foraging by loggerhead turtles in Shark Bay, Western Australia. Marine Ecology Progress Series 453: 213-226.

Thomson, J. A., D. A. Burkholder, A. B. Cooper, M. R. Heithaus, and L. M. Dill. 2012. Heterogeneous patterns of availability for detection during visual surveys: spatiotemporal variation in sea turtle dive-surfacing behaviour on a feeding ground. Methods in Ecology and Evolution 3: 378-387.

Burkholder, D., M. R. Heithaus, J. Thomson, and J. A Fourqurean. 2011. Diversity in trophic interactions of green sea turtles (Chelonia mydas) on a relatively pristine coastal foraging ground. Marine Ecology Progress Series 439:277-293.

Heithaus, E.R., P. A. Heithaus, M. R. Heithaus, D. Burkholder, and C. A. Layman. 2011. Trophic dynamics in a relatively pristine subtropical fringing mangrove community. Marine Ecology Progress Series 428: 49-61.

Dunphy-Daly, M.M., Heithaus, M.R., Wirsing, A.J., Mardon, J., Burkholder, D.A. 2010. Predation risk influences the diving behavior of a marine mesopredator. The Open Journal of Ecology. (3): 8-15

Heithaus, M. R., A. J. Wirsing, D. Burkholder, J. Thomson, and L. M. Dill. 2009. Towards a predictive framework for predator risk effects: the interaction of landscape features and prey escape tactics. Journal of Animal Ecology 78: 556562

Thomson, J. A., D. Burkholder, M. R. Heithaus, and L. M. Dill. 2009. Validation of a rapid visual-assessment technique for categorizing the body condition of green sea turtles (Chelonia mydas) in the field. Copeia 2009: 251-255.

Heithaus, M. R., A. J. Wirsing, J. Thompson, and D. Burkholder. 2008 A review of lethal and non-lethal effects of predators on adult marine turtles. Journal of Experimental Marine Biology and Ecology 356: 43-51.

Heithaus, M. R., D. Burkholder, R. E. Hueter, L. I. Heithaus, H. W. Pratt Jr, and J. C. Carrier. 2007. Spatial and temporal variation in shark communities of the lower Florida Keys and evidence for historical population declines. Canadian Journal of Fisheries and Aquatic Sciences 64: 1302-1313.

Heithaus, M. R., A. Fird, A. J. Wirsing, L. M. Dill, J. Fourqurean, D. Burkholder, J. Thomson, and L. Bejder. 2007. State-dependent risk-taking by green sea turtles mediates top-down effects of tiger shark intimidation in a marine ecosystem. Journal of Animal Ecology 76: 837-844. 